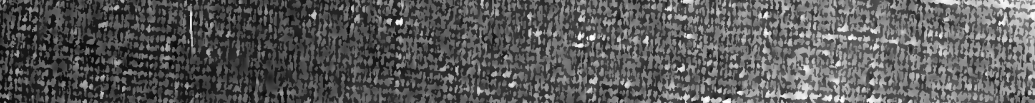
4. 5 .
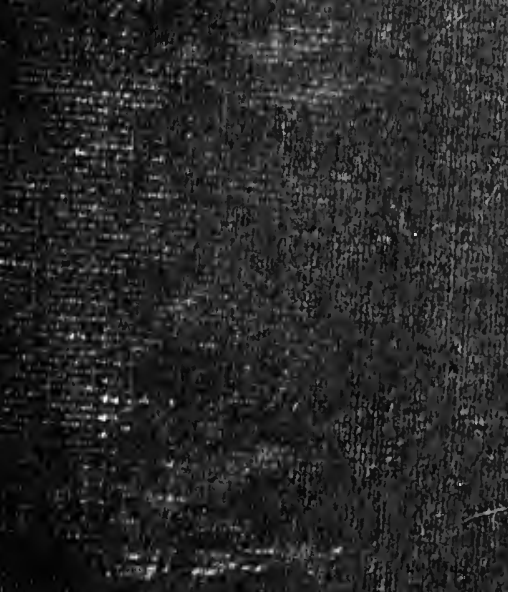

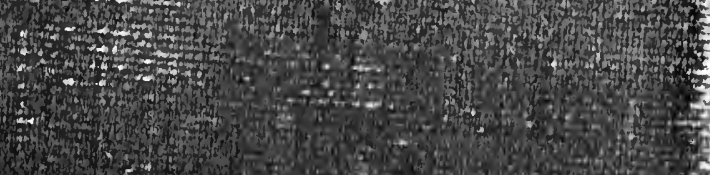





Digitized by the Internet Archive in 2008 with funding from Microsoft Corporation 
FRENCH POTTERY

AND PORCELAIN

NEWNES' LIBRARY OF

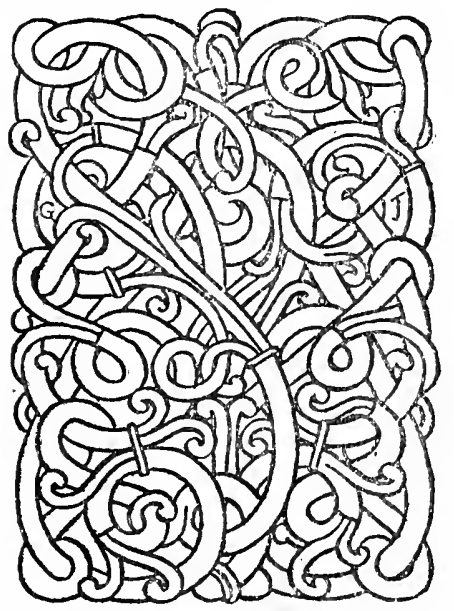

THE APPLIED ARTS 




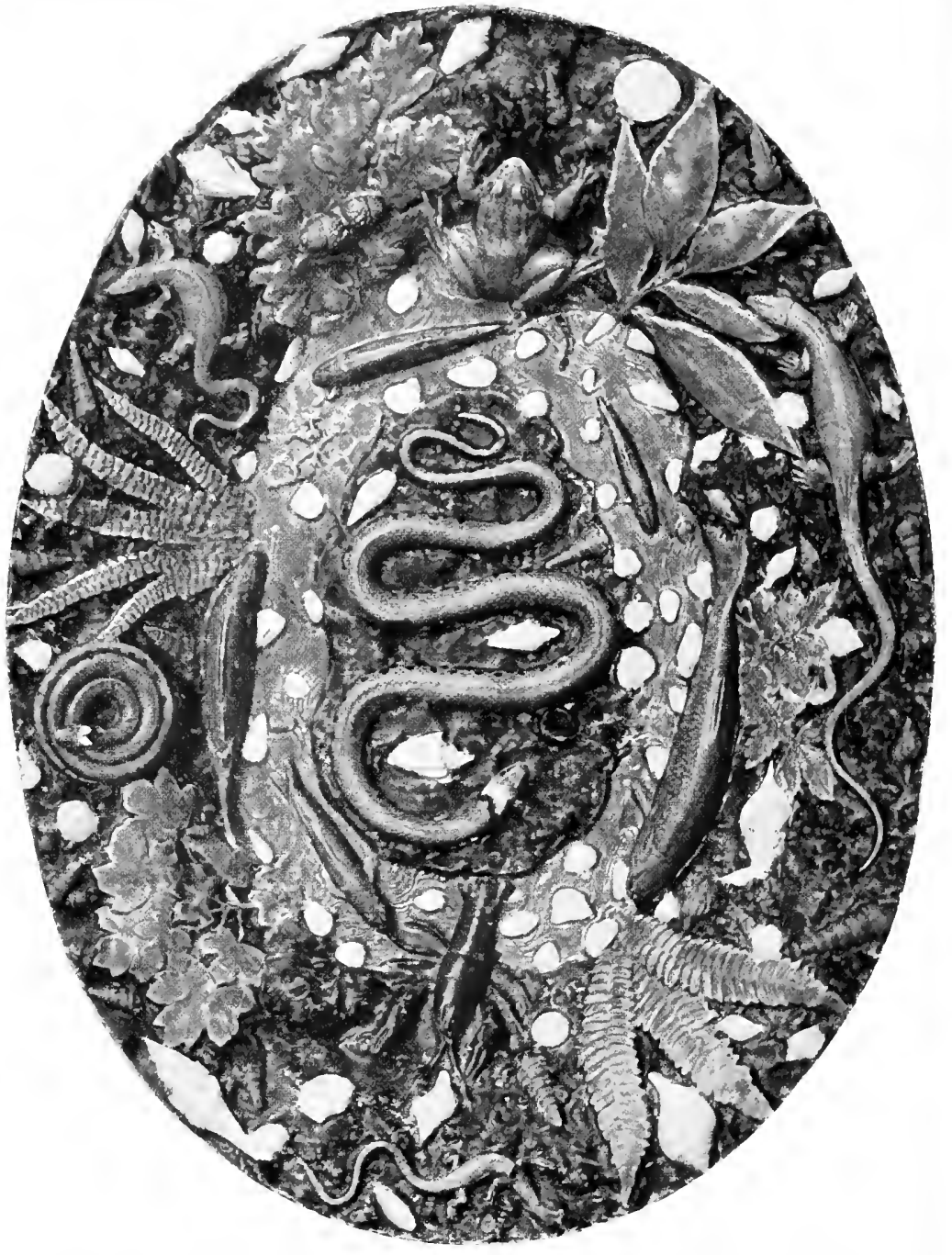

PAISST IFARE DHAH South Kensington Nusetum lenuth 21 inches. Width 16 inches. 


\title{
FRENCH POTTERY AND PORCELAIN
} BY HENRI FRANTZ

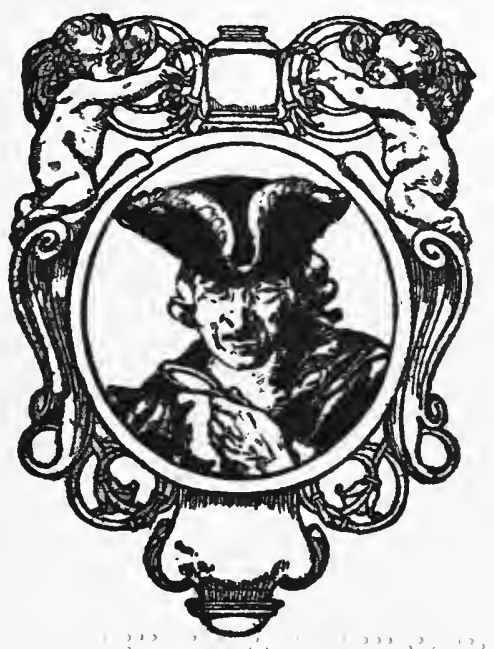

\author{
LONDON \\ GEORGE NEWNES LIMITED \\ SOUTHAMPTON ST. STRAND W.C. \\ NEW YORK \\ CHARLES SCRIBNER'S SONS

$$
41074
$$




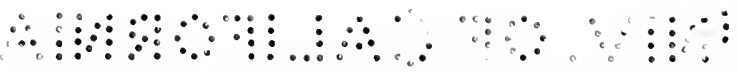

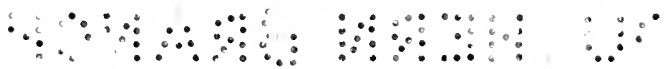

$$
2 v
$$




\section{CONTENTS}

CHAPTEK

List of Illustrations-

PaCie

I. French Ceramic Art in the Sixteenth Century. I

II. Bernard Palissy (15IO-I590)

III. Faience: Nevers . • • . • • • . . 2 I

IV. Faience : Rouen . . . . . . . . . . 29

V. Faience: Moustiers . . . . . . . . . 43

Vi. Faience: Marseilles . . . . . . . . 53

VII. Strasburg and the Manufactories of alsace.

LORRAINE . . . . . . . . . . .

NiederWiLler . . . . . . . . . . 72

Lunéville • • • • • • • • • • • . 75

Bellevue • • . .

Vili. Other French Manufactories of Faience . .78

LiLLE . • • • • • • • . . 78

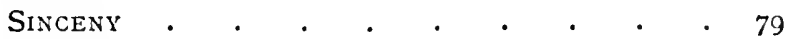

Sceaux . . . . . . . . . . 81

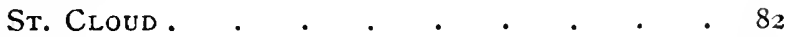

PARIS . . . . . . . . . . 82

APREY . . . . . . . . . . .

BORdEAUX . . . . . . . . . . . .

SAINT OMER

Saint Amand . $. \quad . \quad . \quad . \quad . \quad . \quad . \quad 84$

QUINPER . . . . . . . . . . .

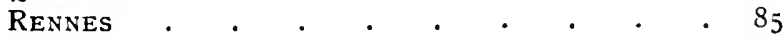

MontPellier . . . . . . . . . 85

Montauban . . . . . . . . . . 86

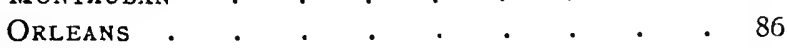

VARAGES . . . . . . . . . . .

Samadet . . . . . . . . . . . . 86

Desvres and Hesdin . . . . . . 86 


\section{FRENCH POTTERY \& PORCELAIN}

CHAYTER PAGE

IX. Sìvres . . . . . . . . . $87^{\mathrm{V}}$

X. Various Manufactories of Porcelain . . . IzO

ROUEN . . . . . . , . . I2O

St. ClOUd . . . . . . . . . . $12 \mathrm{I}$

LILLE . • . . . . . . . . I 22

Chantilly . . . . . . . . . . . 122

Mennecy . . . . . . . . . . . 123

PARIS . . . . . . . . . . . 123

Vincennes . . . . . . . . . . 125

Sceaux . . . . . . . . . . 126

Orleans . . . . . . . . . . 127

Strasburg . $. \quad . \quad . \quad . \quad \cdot \quad \cdot \quad \cdot \quad \cdot 127$

LIMOGES . . . . . . . . . 127

Bordeaux . . . . . . . . . 128

Arras . . . . . . . . . . 128

Valenciennes . . . . . . . . . . 128

Xi. List of Pieces of French Faience and Porcelain SOLD SINCE I882. . . . . . . . 130

Marks and Monograms on Faience and Porcelain . 152

Useful Books of Reference. • . . . . . . I53

INDEX . $\quad . \quad . \quad 155$ 


\section{LIST OF ILLUSTRATIONS}

\section{COLOURED PLATES}

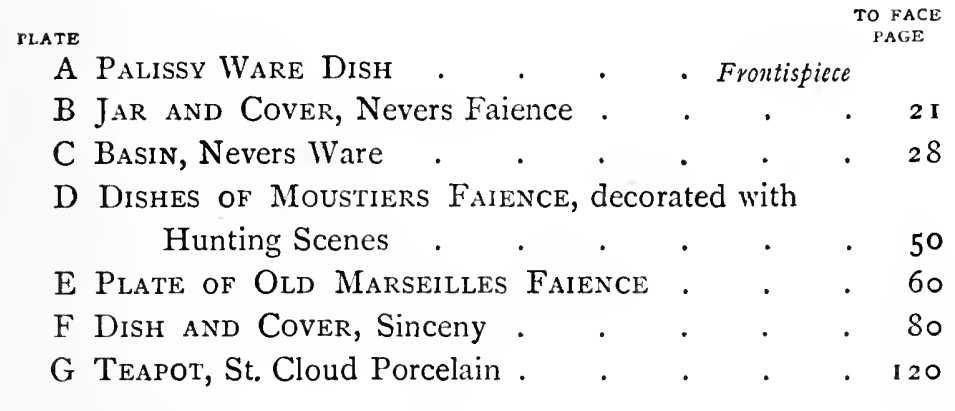

\section{IN BLACK AND WHITE}

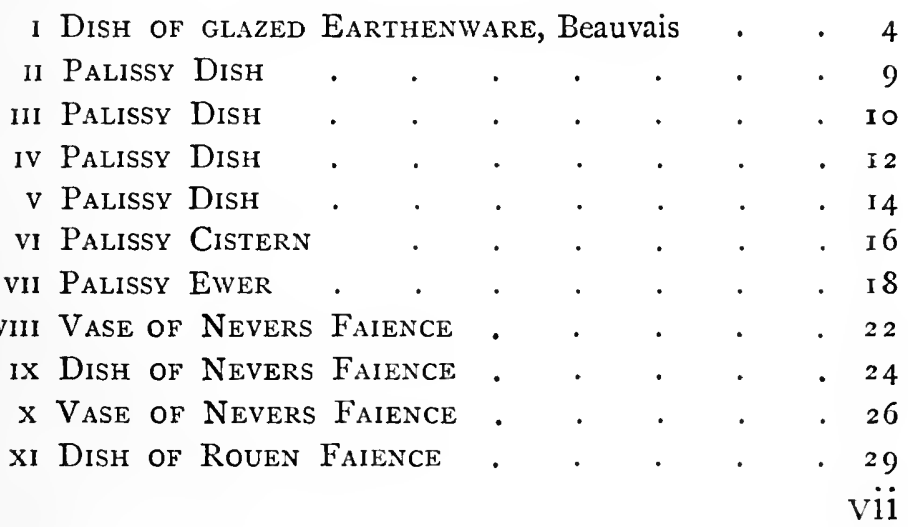




\section{FRENCH POTTERY \& PORCELAIN}

PLATE

Xil Ewer of Rouen Faience . . . . 30

xili Ewer of Rouen Faience . • . . 32

xiv Dish of Rouen Faience . . . . 33

XV Dish of Rouen Faience . . . . . 34

Xvi Plate, with Musical Inscription . . . 35

xvi Plate, with Musical Inscription . . . 36

xvili Plate of Rouen Faience . . . .37

xix The Faience Violin-Back . . . . 38

xx The Faience Violin-Front. . . . 39

xxi A Corner in The Rouen Museum, showing the famous celestial and terrestrial globes . . 40

xxil Inkstand of Rouen Faience • • • 4 I

xxili Soup Tureen and Cover of Rouen Faience . 42 xxiv "Mater Salvato," bas-relief of Old Moustiers

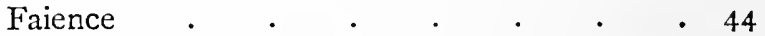

XXV "SAINT Joseph," bas-relief of Old Moustiers Faience . . . . . . . . 46

xxvi Group of Old Moustiers Faience • $\quad 48$

xxvil Water Jug and Dish, Old Moustiers Faience $5 \mathbf{2}$

xxvili Covered Bowl with Stand, of Old Marseilles

Faience . . $\quad . \quad$. $\quad . \quad$. 53

xxix Group of White Marsellles Faience . 54

xxx Milk Jug and Sugar Basins of Old MarSEILles Faience . . . . . . 56

xxxi Group of Old Marseilles Faience . $\quad 58$

xxxil Group of Old Marseilles Faience • . 62

xxxill Group of Old Marseilles Faience of objects made by Robert for the wedding of his daughter . . . . . . . 64

xxxiv Plates and Dishes of Old Marseilles FAIENCE . . . . . . . 65

xxxy Fountain of Strasburg Ware . . . 66

xxxvi Vase of Strasburg IVARe . . . . 68

xxxvil Plate of Strasburg Porcelain • • . 69

viii 


\section{LIST OF ILLUSTRATIONS}

PLATE

TO FACE

P'AGE

xxxvili Plate, Strasburg Faience . . . . 70

XXxix Niederibiller VASe • • • • • . 72

xl Plate, Niederwiller Faience • • $\quad .73$

xli Niederililler Tray . • • • • $\quad$. 74

xliI Statuette by Lemire, Niederwiller . . $\quad 76$

xliil Plate, Lunéville Faience • • . . 78

xliv Covered Vase, Sceaux Falence . . . S2

Xlv Vase, Soft Porcelain of Vincennes . . 87

xlvi Dish, Soft Porcelain of Sèvres . . . 90

xlvil Tray, Soft Porcelain of Sèvres . • . 94

xlviil Jar with Cover, Soft Porcelain of Sk̇vres $\cdot 98$

xlix Figure, Soft Porcelain of Sk̇vres . . 102

L Tray, Hard Porcelain of Sèvres . . IO4

li Group, Sèvres Porcelain . . . . 108

li Group, Soft Porcelain of Sk̀vres . 112

lin Clock, Sèvres Porcelain, Louis XV. period . i i 6

liv Vase, Soft Porcelain of St. Cloud . . I 2 I

lv Figure, Soft Porcelain of Chantilly . . I 22

lvi Vase with Cover, Porcelain of Chantilly . I 24

lvil Vase, Soft Porcelain of Mennecy . . I 26

lvil Covered Dish on Legs, Hard Porcelain of

Strasburg . . . . . . . . I 8

LIX to LXX Marks and Monograns on Faience and

Porcelain . . . . . . 152 


\section{ERRATA}

Page 29, last line, for " than " vead " that." Page 69, foot-note f, for "XI." read "IX." Page I28, line 2 from top, for "by " read "to." 


\section{FRENCH POTTERY AND PORCELAIN}

THE FIRST CHAPTER

\section{FRENCH CERAMIC ART IN THE XVITH CENTURY}

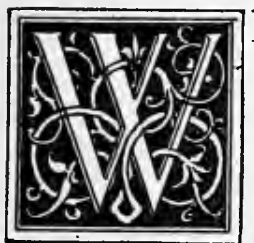

HEN we study the various works of art produced by France during the fifteenth and sixteenth centuries in the way of painting and sculpture, or when we admire the magnificence of her cathedrals and the marvels achieved in jewellery and tapestry at that time, we cannot but be surprised to find how relatively late was the development of French ceramic art, and how this art, which was to be one of France's glories in the seventeenth and eighteenth centuries, was neglected during the period of the Renaissance. While keeping pace with Italy, and submitting to the influence of her painters and sculptors, France seemed blind to the splendid achievements of Italian majolica, then at its best. And yet Italian 


\section{FRENCH POTTERY \& PORCELAIN}

potters had crossed the Alps, to visit, like other artists, the court of Francis I. ; Piccolpasso had published his didactic works upon the art, which every one could consult; and many Italian potters had settled in French towns. In our chapter on Marseilles we shall speak of their first essays in the South of France; but Italian potters were to be found established elsewhere as well, notably at Nantes. Girolamo della Robbia had decorated the Château de Madrid in the Bois de Boulogne with a facing of ornamental faience.* There was a factory at Rouen in I 442, of whose products nothing is known; but two pictures composed of enamelled tiles, representing the stories of Marcus Curtius and Mucius Scævola, were made at another established there in the sixteenth century. These tiles, on which are depicted thoroughly Italian subjects, formed part of the pavement of rooms in the Château d'Écouen, built by the Constable de Montmorency. One of them bears the inscription: " $\bar{A}$ Rouen. 1542." Now, thanks to the researches of André Pottier, it has been proved that there lived at Rouen a potter named Masseot * Now in the Museum at Sèvres. 


\section{FRENCH CERAMIC ART}

Abaquesne, mentioned in various documents as having furnished " a certain number of tiles in enamelled clay for the high and mighty lord, Messire the Constable, Grand Master of France." It was, therefore, Abaquesne who executed not only these tilepictures but also other existing worksnotably some tiles now in the Louvre, on which are to be seen the shield of Montmorency and the Constable's sword. After Abaquesne, Rouen for nearly two centuries entirely ceased making pottery; the history of her great period will be told further on.

About the year $\mathbf{I} 556$ there was also a factory at Lyons, which had but an ephemeral existence, and produced faience ornamented with designs and figures-imitations, bearing French inscriptions, of the Urbino manufactures in their decadence.

The poverty of ceramic production in the fifteenth century and beginning of the sixteenth, up to the time of Bernard Palissy, is probably partly due to the great vogue which Limoges enamels then had in the country. The great nobles, who might have encouraged the budding artistic industry as did their compeers in Italy, were only 


\section{FRENCH POTTERY \& PORCELAIN}

interested in the dishes, jugs, and boxes that issued from the workshops of Pénicaud, Pierre Raymond, and Courtois, and neglected the first experiments in ceramic art.

The exact origin of that beautiful ware known as faience de Henvi II., of which there are extant only about forty specimens, remains a difficult question. The most varied opinions have prevailed as to its mysterious source. Thus Sommerard, the creator of the Cluny Museum, held that it was introduced from Beauvais; while M. André Pottier pronounces in favour of Florence. Thoré attributes it to Ascanio, a pupil of Benvenuto Cellini; M. Delange, to Girolamo della Robbia. But none of these excellent authorities, any more than even M. Benjamin Fillon, who about I 862 became the recognised historian of this interesting ware, have succeeded in discovering its remote antecedents; nor shall we attempt the task here. What we do at least know tolerably clearly is the actual history of the ceramic manufacture of the little town in the department of Deux-Sèvres.

Hélène de Hangest, lady of Boissy, widow of Artus Gouffier, former tutor of 4 


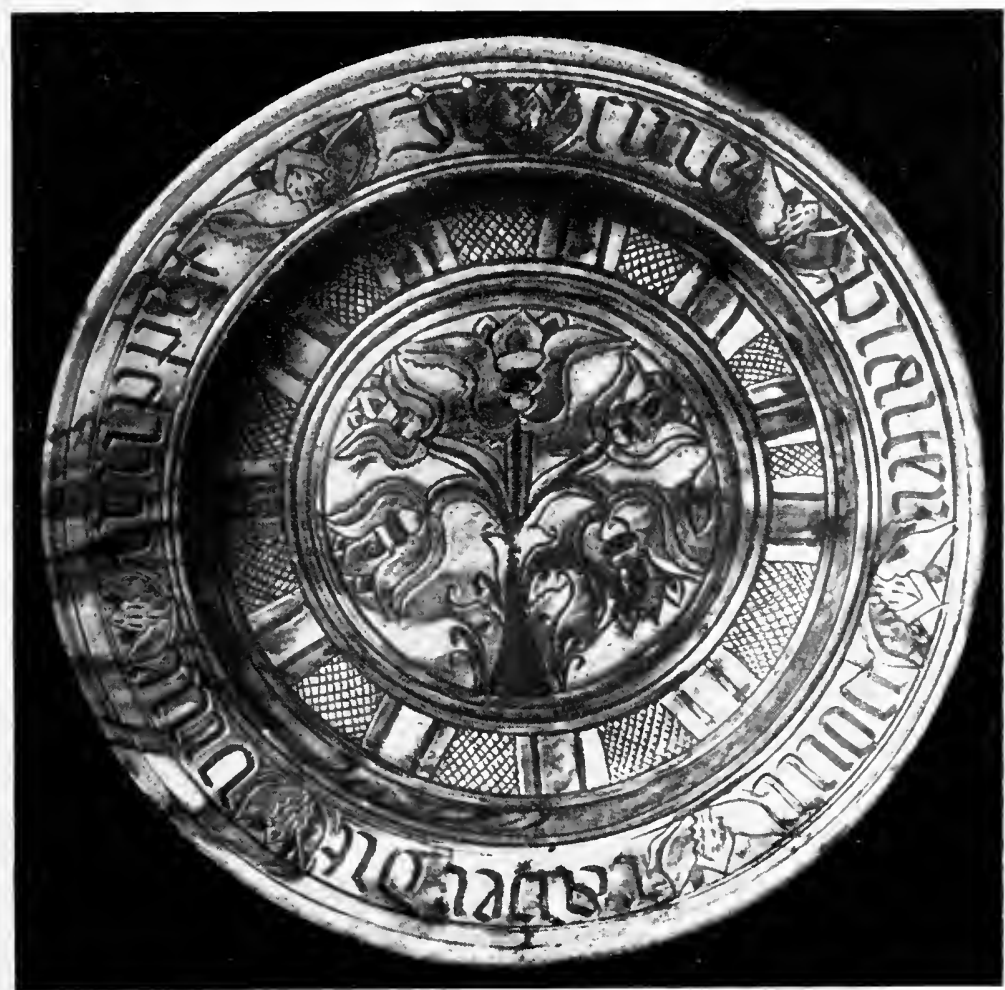

$$
\text { D. } 17^{\prime \prime}
$$

[Phote, D. Freuler, Paris

DISH OF GLAZED EARTHENWARE, Beauvais. XV Or XVI century. Sivres Museum. 



\section{FRENCH CERAMIC ART}

Francis I., and Grand Master of France, instituted this manufacture in her Château of Oiron, where she lived during a part of each year. She was a woman of learning and of artistic sympathies, and had made a collection of contemporary crayon portraits, for which Francis I. had written some verses. Among the potters who worked for her we only know the name of François Cherpentier, with which is associated that of Jehan Bernart, the lady's secretary, and the custodian of her library.

The latter certainly exercised considerable influence over the decoration of the faience; for we find designs and ornaments copied from beautiful sixteenth-century books, and these are imprinted on the still soft clay by means of iron implements, traces of which are still to be found. Hélène de Hangest began the manufacture of faience in 1524 ; she died in 1537. All the work produced under her auspices is distinguished by the fine quality of its paste, white, but covered with a thin transparent varnish of a slightly yellowish tint, so as to give the whole a look of ivory. The ornamentation consists of interlacing lines, arabesques, floral designs, heraldic 


\section{FRENCH POTTERY \& PORCELAIN}

devices, and emblems, wrought into the paste in either black or some dark tone of colour. In shape the objects are light, dainty, and graceful. They are for the most part covered cups, biberons with tall handles, ewers, flagons, and salt-cellars, and have generally some ornamentation in relief. Many bear the arms of Gilles de Laval, of the Seigneur de Bressuire, of the La Trémouille family, or of the Gouffier family. Some of them, and also some imitations, have the cypher of Henri II. and the crescents of Diane de Poitiers.

After the death of Hélène de Hangest her son, Claude Gouffier, continued the manufacture, though with less taste. This is the second period (1537-1563) of the faience d'Oiron. Claude Gouffier was much attached to Henri II., then Dauphin, and had many pieces made for him bearing the escutcheon of France with the Prince's own device. These pieces, outnumbering all the others, gave to this ware its appellation of faience de Henri $I I$. In this second period the shapes, heavier and more complex than those of the preceding period, are for the most part borrowed from architectural 6 


\section{FRENCH CERAMIC ART}

designs; and the salt-cellars, candlesticks, biberons, cups, and goblets, do not always display the purest taste. Yellow ochres are introduced as a novelty in colouring, and ornaments in relief are more frequent. The cyphers of Henri II. and of Diane de Poitiers are often to be seen.

The third period is that of decadence. After Claude Gouffier the factory was left without a guiding spirit, and his successors lost all the traditions of fine form and of exquisite material. Ornamentation was applied at haphazard; the reliefs were executed coarsely and without finish. In certain pieces the influence of Bernard Palissy is apparent, particularly in the representation of various reptiles, and in the execution of some rustic figures.

The extreme rarity of this faience explains the high prices it has always commanded; in fact, nearly all the existing specimens are now in museums, and it therefore rarely comes into the market.

Belonging to the same period as the faiences d'Oiron are the pottery of Pré d'Auge, and the terminal ornaments for ridge-pieces* which were used to adorn the * Épis de faîtage or étocs. 


\section{FRENCH POTTERY \& PORCELAIN}

gables of the wooden houses of the Renaissance. Various factories in the department of Eure, such as Armendières, Verneuil, and Malicorne, produced these ceramic decorations. Those of Pré d'Auge, not far from the same neighbourhood, are the finest, and are remarkable for their harmonious colouring. Dishes with subjects in relief, flagons, and pilgrim's-bottles, were likewise made at Pré d'Auge, which was producing at the same time as was the workshop of Palissy and his successors. Indeed for a long time the pottery of Pré d'Auge passed for Palissy's, from which it is to be distinguished by its being less glazed in the marbling. 



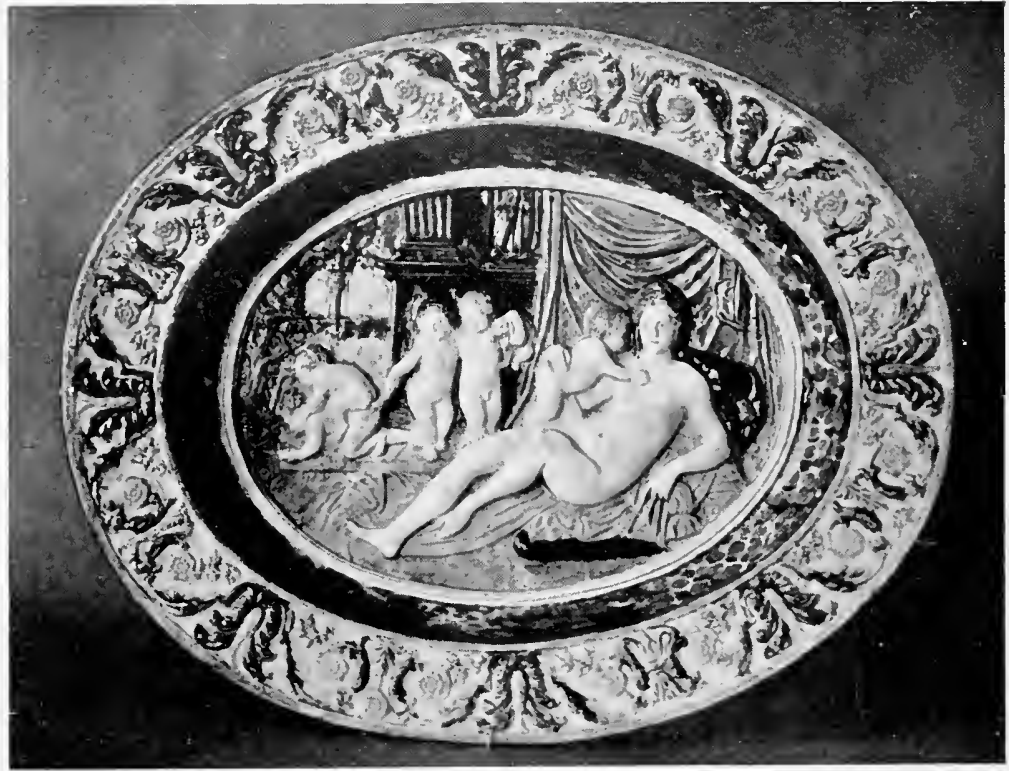

L. Iy!" W, 16"

PALISSY DISH. Collection of George Salting, Esq. 
THE SECOND CHAPTER

\section{BERNARD PALISSY (I5IO-I590)}

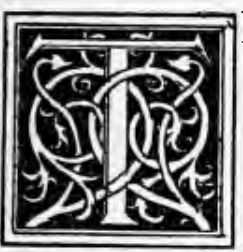

$\mathrm{HE}$ greatest figure in the history of sixteenth-century French ceramic art is Bernard Palissy, who in his work and in the multiplicity and variety of his knowledge showed himself to be not only one of the most enlightened spirits of his period, but a man altogether in advance of his age. He was born in 1510 at the Chapelle Biron in Périgord, near the château of Biron. Little is known concerning his youth ; except that in his earlydays he practised as a painter on glass, a portrait-painter, and a land-surveyor, and that he travelled in France, in Flanders, and in Germany. From the fact of his sojourn in the latter country some have attempted to draw the inference that he got the secret of his enamel from Hirschvogel, of Nuremberg. The Hirschvogel family, it is true, is famous in Nuremberg: from the end of the fifteenth to the end of the sixteenth century it produced several generations of engravers on glass, engravers on copper, and distinguished 


\section{FRENCH POTTERY \& PORCELAIN}

enamellers. Possibly during his stay among them Palissy may have felt himself confirmed in his vocation for ceramic art; but at all events, that the secret of his white enamel was not imparted to him is proved by the fact that he sought for it long and painfully, and only discovered it as the reward of the most strenuous effort.

At Saintes, where he settled about 1542, he began his researches into the composition of enamels. Let us turn to the narrative of the potter himself, more interesting in its rude eloquence than any number of commentaries: "Twenty-five years ago," he writes, "I was shown an earthen cup turned and enamelled,* so beautiful that from that moment I entered into dispute with myself, remembering many things that certain persons had told me, making mock of me, when I was painting pictures. Now, seeing that these were no longer much wanted in the part of the country where I dwelt, and that neither was glasspainting in great request, I began to think that if I found out the invention of making enamel I could make vessels of clay and other things

* What was this cup? Doubtless one seen in Germany; perhaps at the Hirschvogels', in Nuremberg. IO 


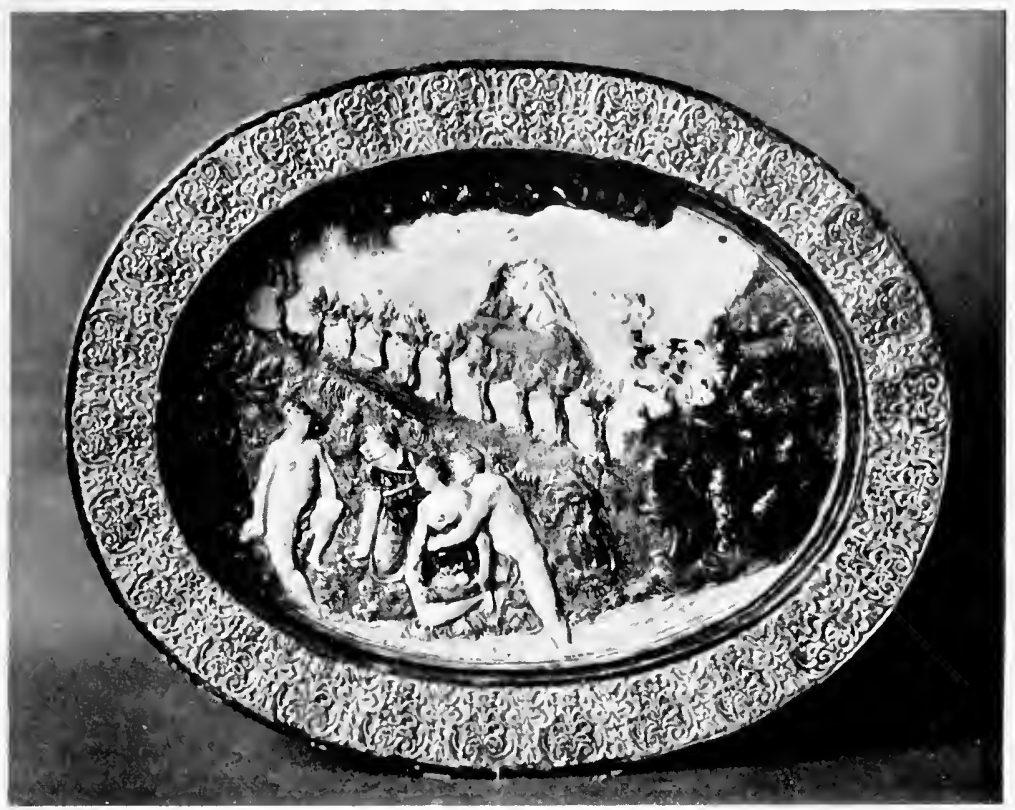

L. I4!" W. 10 ?"

PALISSY DISH. Collection of George Salting, Esq. 



\section{BERNARD PALISSY}

of comely favour, as God had granted me to understand somewhat of portraiture; and from thenceforward, without care that I knew nothing concerning argillaceous earths, I set myself to search out enamels like a man who gropes in darkness." And thus during fifteen years he continued to search for a white enamel like that of the cup. True that in this respect Palissy was behind some of his contemporaries, even in France; for Abaquesne at Rouen, and Girolamo della Robbia in Paris, were practising their art with success. But it is just because Palissy sought and found out for himself that his work is so absolutely individual. It was only after incalculable labour that he achieved the discovery of his white enamel. "Upon which," he relates, " another misfortune befel me, causing me great annoyance; which was that running short of wood I was obliged to burn the palings which maintained the boundaries of my garden, the which after being burnt I had to burn the tables and the flooring of my house in order to cause the melting of the second composition. I was in such agony as I cannot express, for I was utterly exhausted and withered up by my work and the heat of the furnace; during more than a month my 
FRENCH POTTERY \& PORCELAIN

shirt had never been dry upon me; even those who ought to have helped me ran crying through the town that I was burning the planks of the floors, so that I was made to lose my credit, and was thought to be mad. Others said that I was trying to coin false money, and I went about crouching to the earth, like one ashamed."

What stumblings in the dark and what mortifications did not the great man suffer with an energy and an endurance uncommon indeed! "The mortar in the walls of my furnace being full of flinty pebbles, these felt the strength of the heat (when my enamels were beginning to liquefy), and split into many pieces, making many outbursts and many explosions in the said furnace. Now as the fragments of the said pebbles flew against thestuff on which I was working, the enamel, which was now liquefied and in a glutinous state, took in the said pebbles and attached them with itself over all the parts of my vessels, which otherwise would have been found beautiful." Palissy had put his last resources into this batch; he had borrowed the wood to fire it; he had engaged the services of a potter for whose keep he was responsible, and whose I 2 


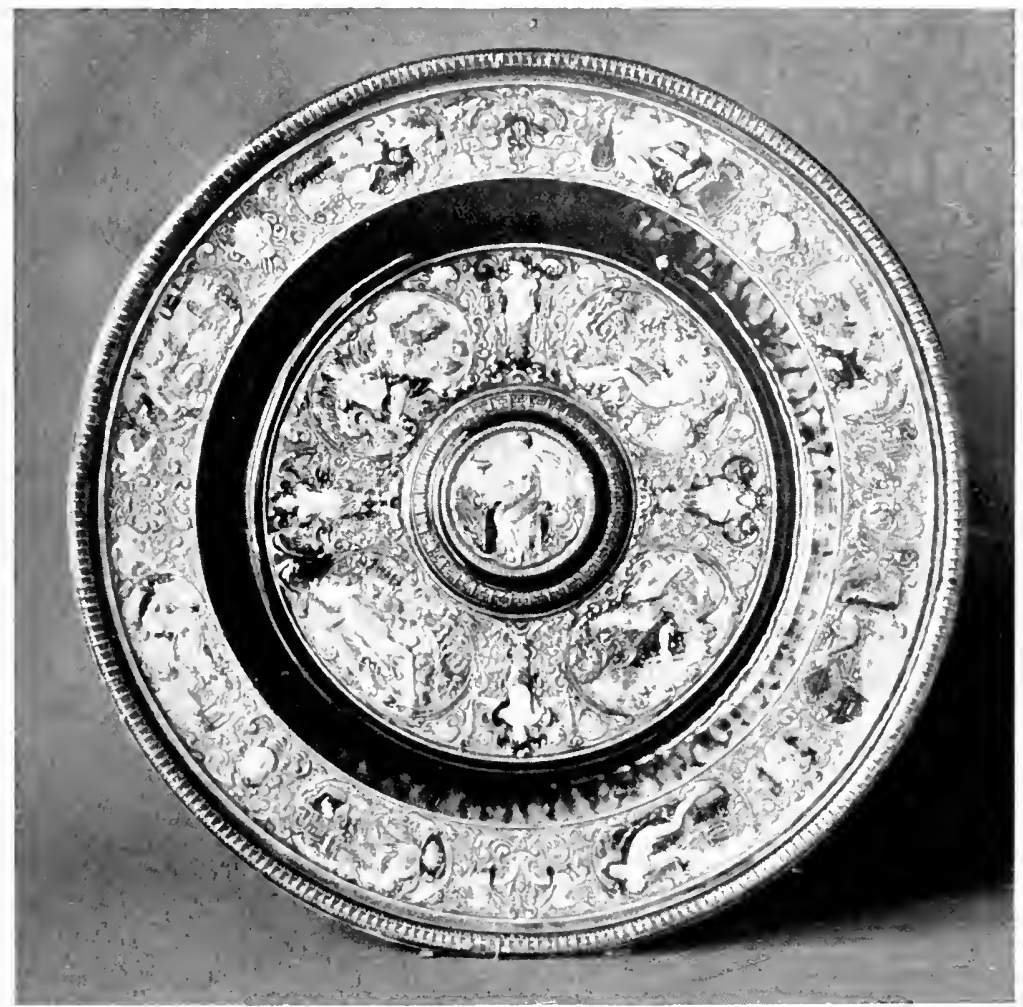

1). $10 !^{\prime \prime}$

PALISSY DISH, Collection of Georcre Salting, Esy. 



\section{BERNARD PALISSY}

wages he owed; and he had his own wife and children to feed! After being at first ill with grief he plucked up all his energy again, and having earned a little money by the exercise of his trade of glass-making, he attempted another batch, which in its turn failed, cinders having stuck to the pieces. To obviate this he invented a sort of earthen lantern, still in use at the present day under the name of cassette, and thus he at last achieved the production of his first faiences, covered with a marbled enamel; later his rustic dishes or basins, ornamented with snakes, frogs, fishes, lizards; and all those admirable rustic pieces to which he owes his great renown. His chief preoccupation then was to imitate Nature with a touching realism and an extraordinary care for truthfulness. Speaking of his lizards Palissy writes that real lizards often came and admired them; and concerning a dog that he had made he says that "many other dogs began to growl on encountering it, thinking it to be alive."

Palissy was at last repaid for all his mortifications by ever-increasing fame. His productions were sought after by the great nobles; and one of his most illustrious patrons, the 


\section{FRENCH POTTERY \& PORCELAIN}

Constable de Montmorency, entrusted him with important work for his Château d'Écouen, but of this, unfortunately, nothing now remains. Meanwhile Palissy had become a Protestant, and when in 1562 the edict of Henri II. punishing the crime of heresy with death was enforced, the master was thrown into prison. It was only thanks to the intervention of de Montmorency that he was spared, on the score that he belonged to the king's household, as "inventor of rustic figurines to the king." After this date he left Saintes, and was settled at La Rochelle for several years; subsequently, about I 565 , moving to Paris, where Catherine de Medici commissioned him to make a rustic grotto in the garden of the Tuileries. His sons assisted him in this work, as is proved by the royal accounts for the year i570: "To Bernard, Nicolas, and Mathurin Palissy, Sculptors in Clay, the sum of 400 livres down and so much the less from the sum of 2600 livres tournois" (i.e., of Tours) "for all the work in baked and enamelled earth which remained to be done in order to perfect and complete the four faces of the interior circumference of the grotto commenced for the Queen in her Palace at I4 


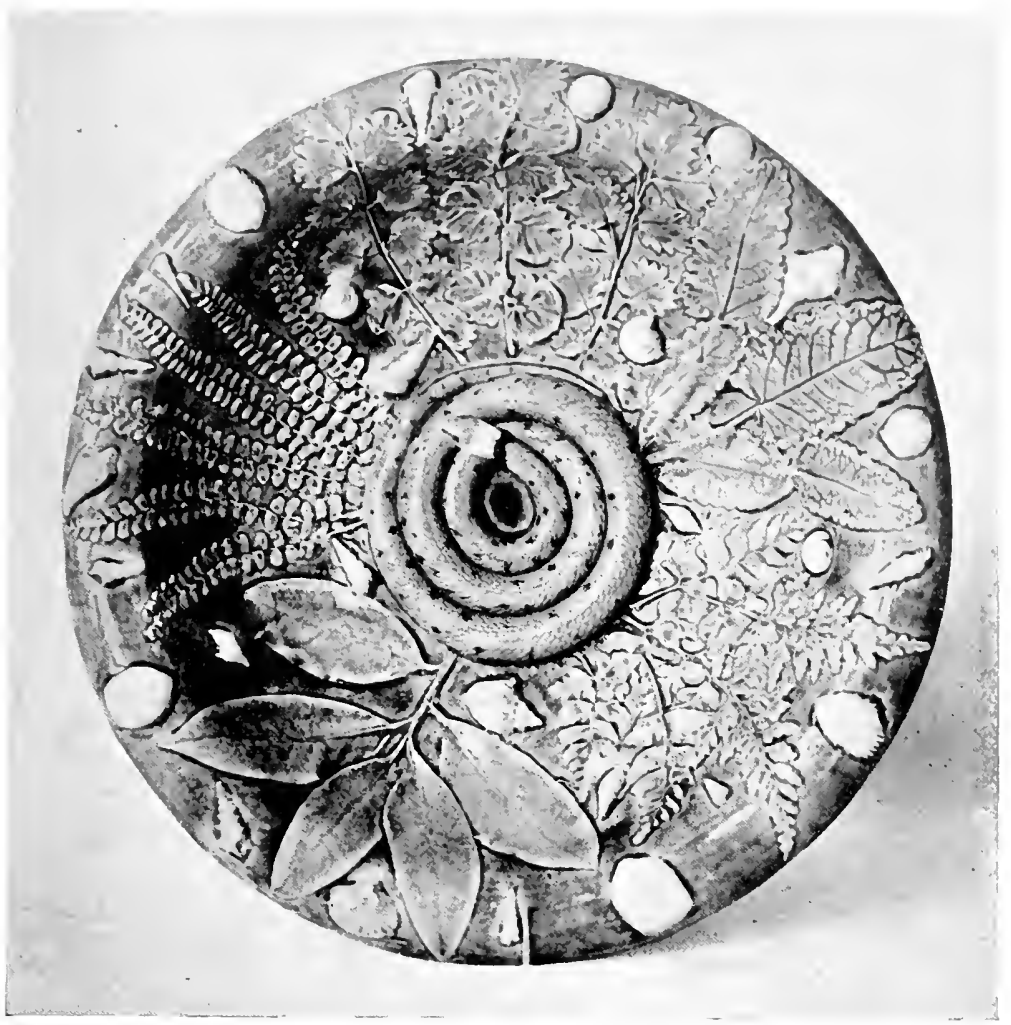

D. ${ }^{1} \mathrm{O}_{2}^{\prime \prime 2}$

PALISSY DISH. Collection of George Salting, Esq. 



\section{BERNARD PALISSY}

Paris according to the bargain made with them."

Denounced by one of his former co-religionists, he was arrested in 1588 . His protectors were now all dead; he had no means of escape from prison, and died there in 1590 at the age of eighty.

When we study the work of Palissy as it is represented to us by the tolerably numerous examples in the Museums of Sèvres, Cluny, and the Louvre, as well as in the Ashmolean and the South Kensington Museums, we find that it may be divided in to three different periods.

First Period.-Of this are the marble dishes, and the first examples of the rustic basins. Although these pieces are less prized by collectors than the productions of the succeeding period, they are none the less fine from the point of view of ceramic art. Palissy never produced anything more beautiful than these brilliant enamels of such limpid purity. Unacquainted with stanniferous enamel, he employed a white paste which was nothing else but carefully purified clay. Brongniart believes that there was a small amount of tin in his enamel; Deck, on the contrary, maintains that he used tin but 


\section{FRENCH POTTERY \& PORCELAIN}

rarely, and then only to tone down the crudity of certain colourings. According to this latter author, in addition to his glaze, which was composed as follows :

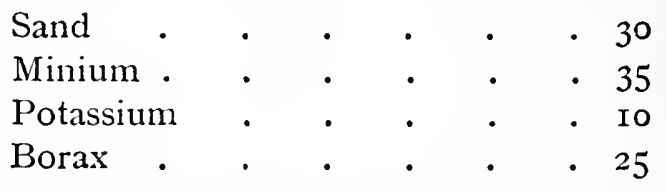

he obtained his yellow enamel with:

Protoxide of iron . . . . Io

his violet enamel with :

Oxide of manganese $\cdot \begin{array}{lll} & \cdot & \end{array}$

Oxide of cobalt . $\cdot$. $\cdot$. 3

his blue enamel with :

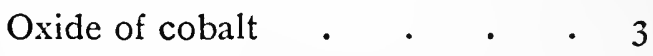

his green enamel with :

Oxide of copper $\cdot$. $\quad \cdot \quad \cdot 4$ and his yellow-brown with :

Oxide of manganese $\cdot$. $\quad 2$

Second Period. - This period is characterised by the manufacture of those rustic pieces which almost always consist of an oval basin in which is seen sometimes an eel lying amid rock-work and shells upon a bed of moss and I6 


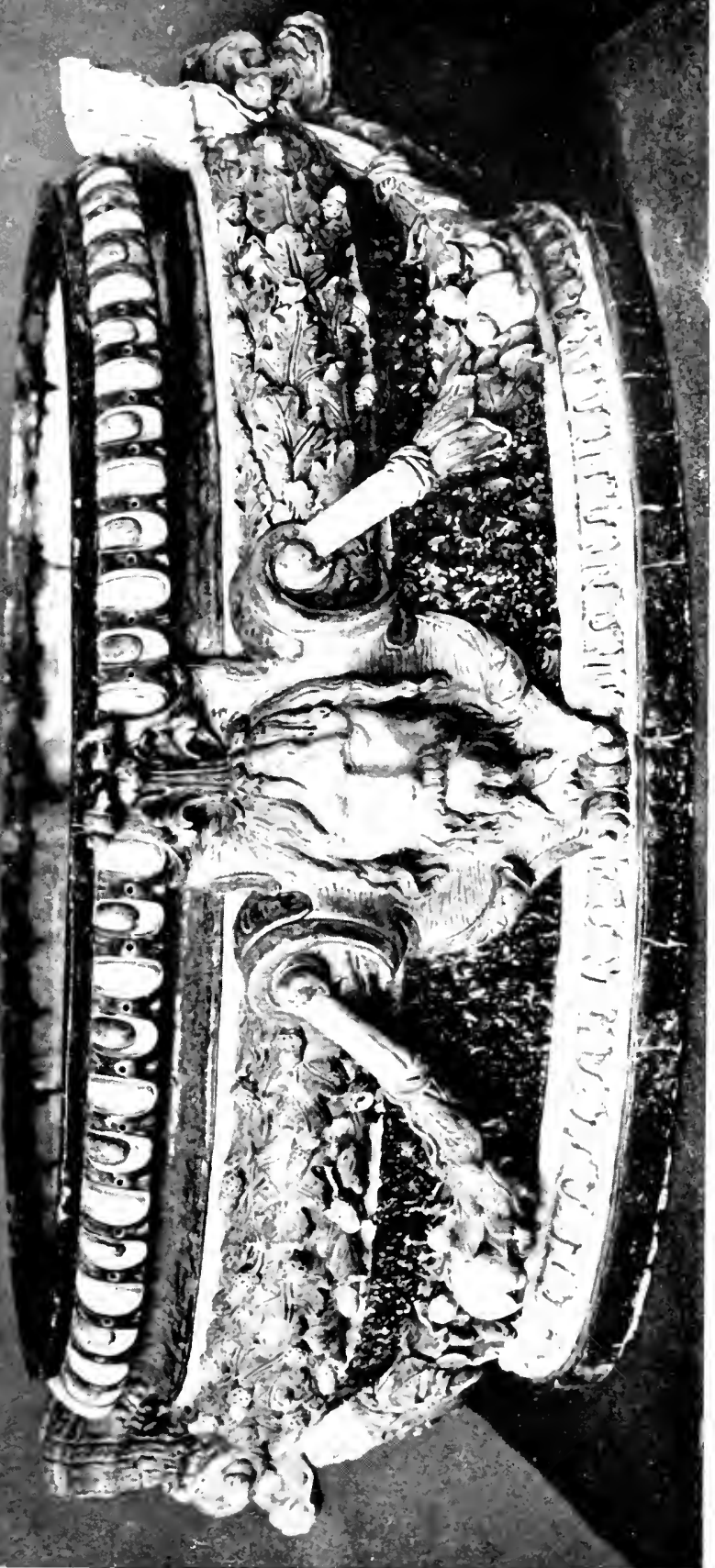





\section{BERNARD PALISSY}

fern, sometimes a coiled viper, around which are seen fish of divers kind, lizards, green frogs, crayfish, insects, and butterflies. Besides these there are also bottles or huntingflasks, and ewers, which are rarer. M. André Pottier-who, with Garnier, is among the best authors who have written on French ceramic art-has discovered in a manuscript of the sixteenth century what was Palissy's mode of procedure. "To prepare the motifs of the composition a sheet of tin was used, upon which was fixed by means of Venetian turpentine the bed of delicately veined leaves, of pebbles, or of petrified substances, that constitutes the usual ground-work of his compositions; upon this was arranged the principal subject, the animals, reptiles, fishes, and insects being fastened down by very fine threads passed through small holes made with an awl in the metal sheet; finally, when the whole had been brought to a point of perfection by the execution of a crowd of details which varied according to circumstances, a layer of fine plaster was run over it all in order to form the mould. The animals were afterwards carefully withdrawn from their plaster envelope, so that nothing hindered their being used immediately 


\section{FRENCH POTTERY \& PORCELAIN}

again in the composition of some other subjects."

To this period also belong the grottos with which he adorned various princely dwellings, such as Écouen, Reux in Normandy, Chaulnes, Nesles, and the Tuileries. Only from this last, or from the workshop which Palissy occupied close to it, have a few fragments of figures moulded on Nature been discovered, and these are now in the Musée Carnavalet.

Third Period.-From this period date the dishes with figure-subjects, little valued by M. Garnier, also the statues or statuettes. These latter were not entirely the work of Palissy, who was no sculptor; they were modelled by him after works by Prieur de Briot or other contemporary artists.

Palissy had no belief in spreading art by the multiplication of cheap things. He did not wish for large productivity. "It is far better," he wrote, "for one man or a small number of men to make their profit from some art by living honestly, than for a large number of men to struggle one against the other, so that they cannot gain a livelihood save by profaning the arts, leaving things half-done."

We need not be astonished that with such I 8 


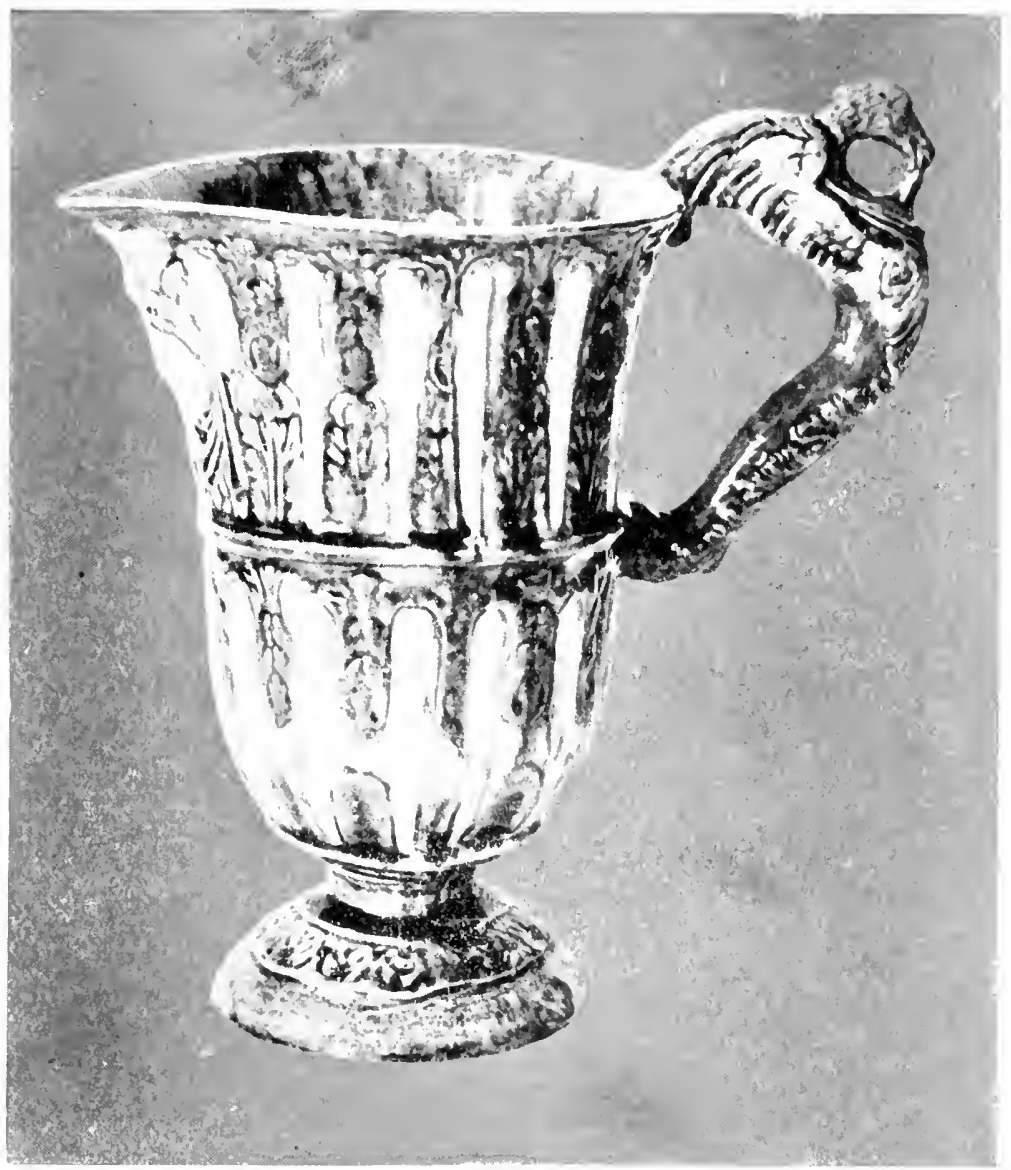

H. 0.

PALISST EWLR. Collection of George Salting. Esq. 



\section{BERNARD PALISSY}

views Palissy had no care to foster ceramic production in any general way, nor that he had but few pupils and imitators. The factory of Avron, near Fontainebleau, alone continued the manufacture of enamels in the style of Palissy, sufficiently perfect to have been in certain instances attributed to him. At Avron were made many of those charming little statuettes: the "Bagpipe-player", the "Tambourineplayer", the "Child pursued by a Hound", and the delightful little "Nurse" of the Ashmolean Museum, to which refers the following fragment of Jean Heroard's journal (I60I-I628):-“April 24, I608.-The Duchess of Montpensier came to Fontainebleau to see the little Duke of Orleans, bringing her daughter aged three years. The little prince embraced her, and gave her a little nurse in pottery which he was holding."

At about the same period Rennes also was manufacturing glazed pottery decorated in relief, which may be recognised by its green colouring veined with deeper tones.

The productions of Beauvais likewise enjoyed a great reputation; these poteries azurees, as they were called by Rabelais and other contemporary authors, being covered 


\section{FRENCH POTTERY \& PORCELAIN}

with a pale blue enamel even in tint. When François I. passed through Beauvais in 1520 , his queen was offered Vases de Savignies. Some fragments of this pottery are to be seen in the Sèvres Museum, notably a flat pilgrim's-bottle on which appears the name of Antoine Loysel, lawyer and historian of Beauvais.

From the sixteenth century onwards Avignon also produced elegant pottery; and this was, perhaps, the one manufactory in France that worked uninterruptedly until the middle of the eighteenth century. 



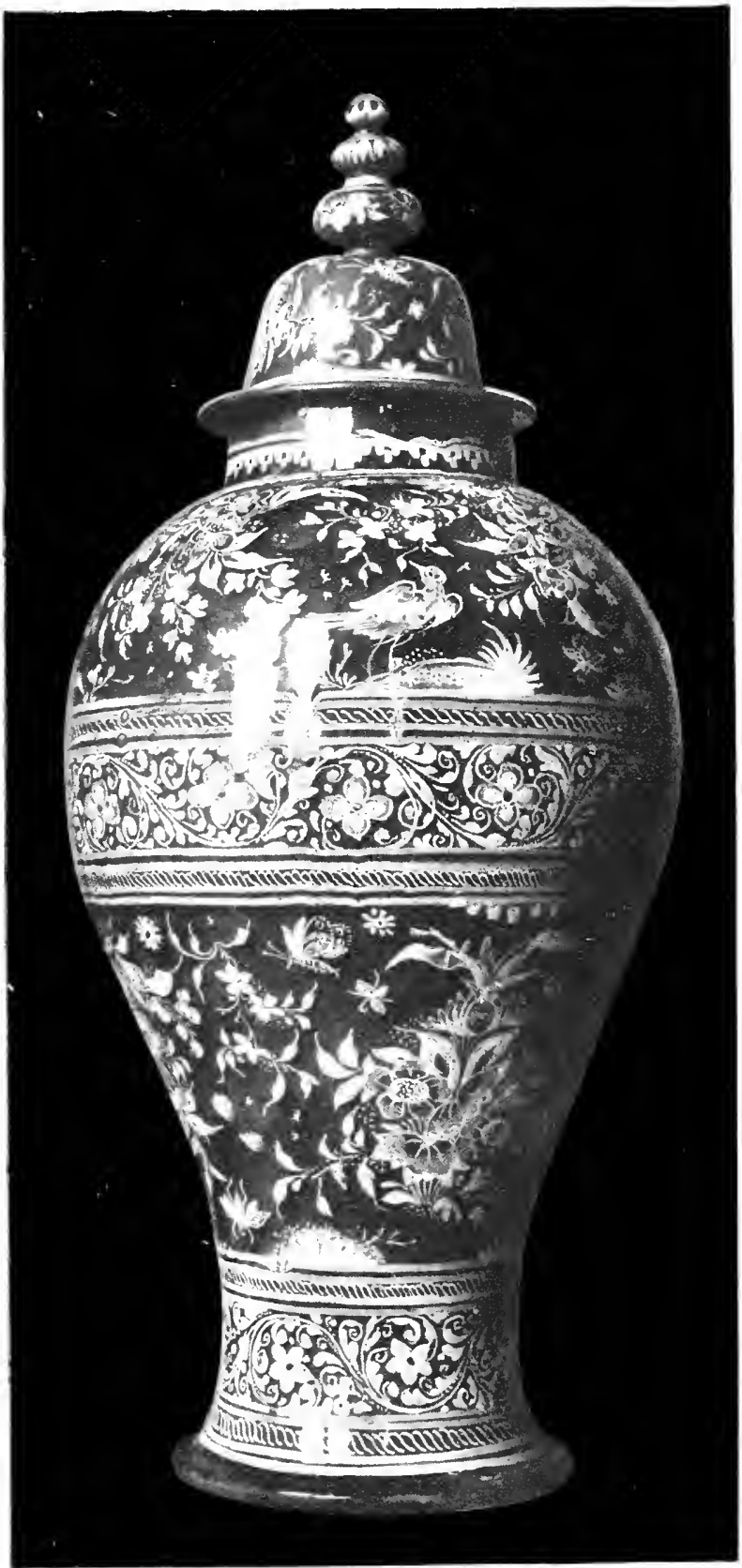

H. $23^{\frac{11}{4}}$

JAR AND COVER, of Nevers Faience. XVII century. 
THE THIRD CHAPTER

\section{FAIENCE : NEVERS}

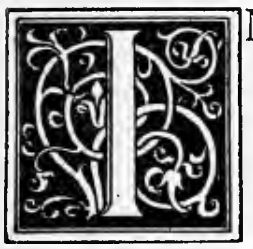

the foregoing chapters we have attempted to review the beginnings of French ceramic art: beginnings which during the fifteenth and sixteenth centuries show us but isolated efforts, rising to genius in the case of such a man as Palissy, yet, when all is told, resulting in an extremely limited output. It was very different in the two following centuries, during which ceramic production became general in all the large towns of France; when great schools came into being, creating, now in pottery, now in porcelain, original works individual in style and ornamentation, and manifesting in the most diverse productions all that decorative invention combined with special ceramic technique which characterised the numerous manufactures of France. Among the many ceramic centres are a few which bespeak an especial admiration, whose wares occupy places of honour in museums and collections. Such, for instance, are Rouen, 


\section{FRENCH POTTERY \& PORCELAIN}

queen of French pottery, and Sèvres, queen of French porcelain; but besides these manufactories, each so famous in its own line, there are others which produced admirable work, and we must study them in turn, beginning with the most ancient-Nevers.

Nevers is certainly one of the great ceramic centres of France; nevertheless, when we examine its productions in a thoroughly impartial spirit, we cannot but arrive at the conclusion that the achievement of this town is infinitely less original than that of other French centres. For Nevers almost always imitated-very perfectly, it is true-and never herself created anything either in structure or ornamentation. Rouen, Moustiers, and Strasburg could at times imitate also-the one Delft, the other Italy, the third Saxony; but at any moment they could free themselves from their models. Nevers, on the contrary, if she ceased to imitate in one manner began in another. If, however, the prestige of Nevers stands low from the point of view of invention, it is none the less the case that in the matter of ceramic technique her achievements are very fine. 


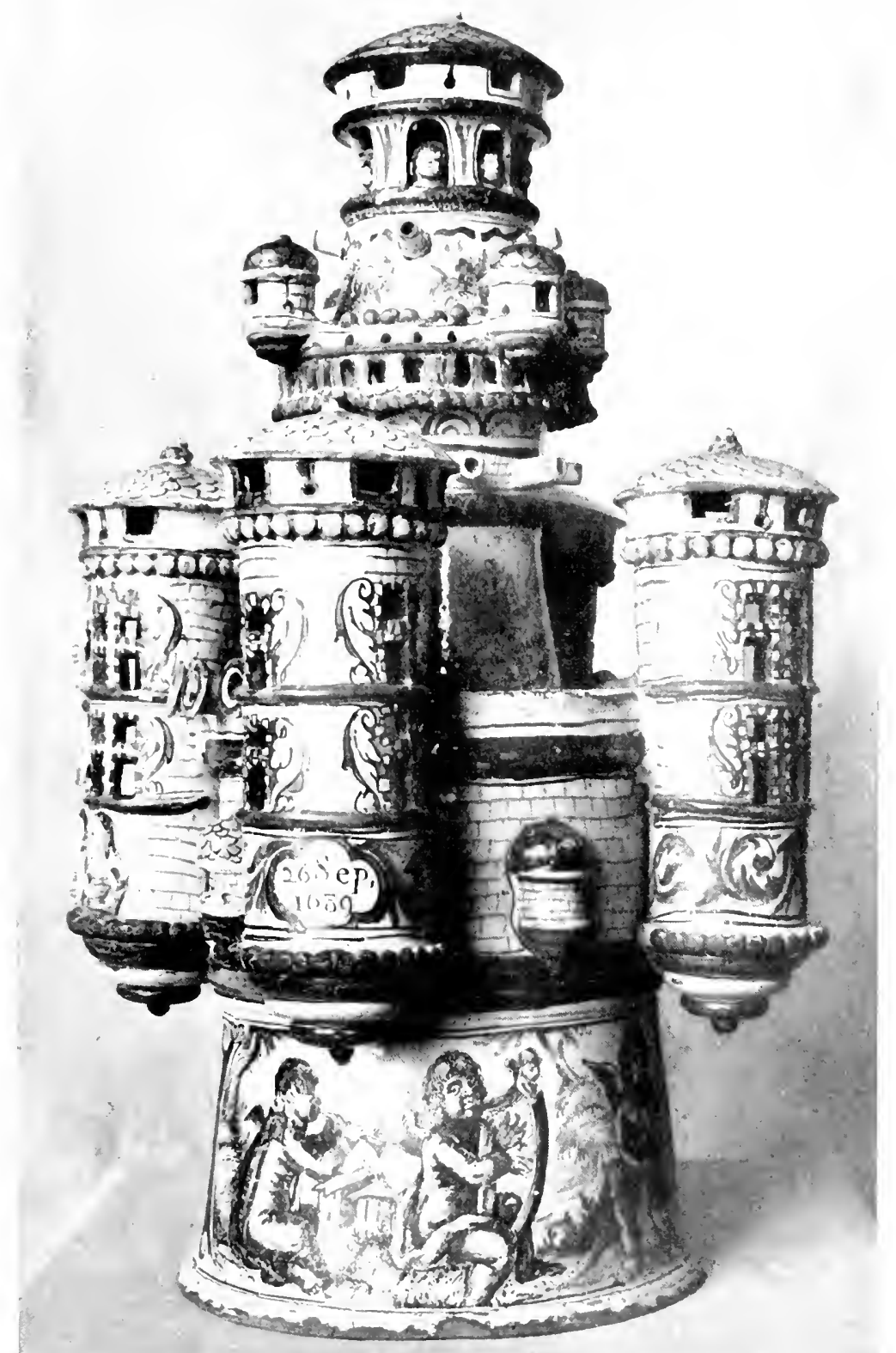

H. $22 !$

[Photo, D. Ficticr, Iuris

NEVERS FAIENCE. Serres Muscun. 



\section{FAIENCE : NEVERS}

Nevers is essentially an Italian town : her green gardens enclosed within high walls, just like those of Ferrara or Verona; her massive and battlemented palaces like those of Florence or Siena-all suggest instantly the influence exercised by Italy over the architectural and artistic development of the beautiful town. The Duke of Mantua, having become Duke of Nevers in 1565 by the marriage of Lodovico Gonzago with Henrietta of Cleves, had brought with him his magnificent Italian court, among whom shone Giulio Romano. We need not be surprised, therefore, if the ceramic art of Nevers was Italian also. Previously there had been nothing of the kind made in Nevers, except some rustic pottery; and the story runs that an Italian huntsman, when hunting one day with the duke, discovered some clay resembling that of his own country, and persuaded the duke into establishing a ceramic factory at the gates of his palace. A family of gentlefolk named Conrade, aided by workmen fetched from Italy, were the first to manufacture the faience. They were three brothers: Dominique, Baptiste, and Augustin, as testify 


\section{FRENCH POTTERY \& PORCELAIN}

the registers for 1602. Dominique's sons afterwards carried on the manufacture alone ; and it is evident that its secrets were carefully kept, for it was not till thirty years later that a second factory was established - that of Barthélemy Bourcier. In $165^{2}$ two others were founded: one by Nicolas Estienne, and the other by Pierre Custode and Esme Godin. This Custode had been brought to Nevers by the brothers Conrade. $\mathrm{His}$ son Jehan, whom he had sent to Rouen to study ceramic manufacture there, was condemned-unjustly, it is said-to banishment from Normandy, because he had been accused by Poterat of throwing dangerous substances into a furnace. The Custodes were the creators of those fine statues of saints and virgins, modelled with such grace, which we admire in museums. We owe to them also a blue faience on which trees, ornaments, and flowers are painted en camaieu (1602-I640); mythological scenes such as the Rape of Europa, Perseus, and other subjects; flasks, amphoræ, drinkingvessels-all these very similar to the productions of Central Italy. The outlines of the figures, trees, and landscapes are traced 24 


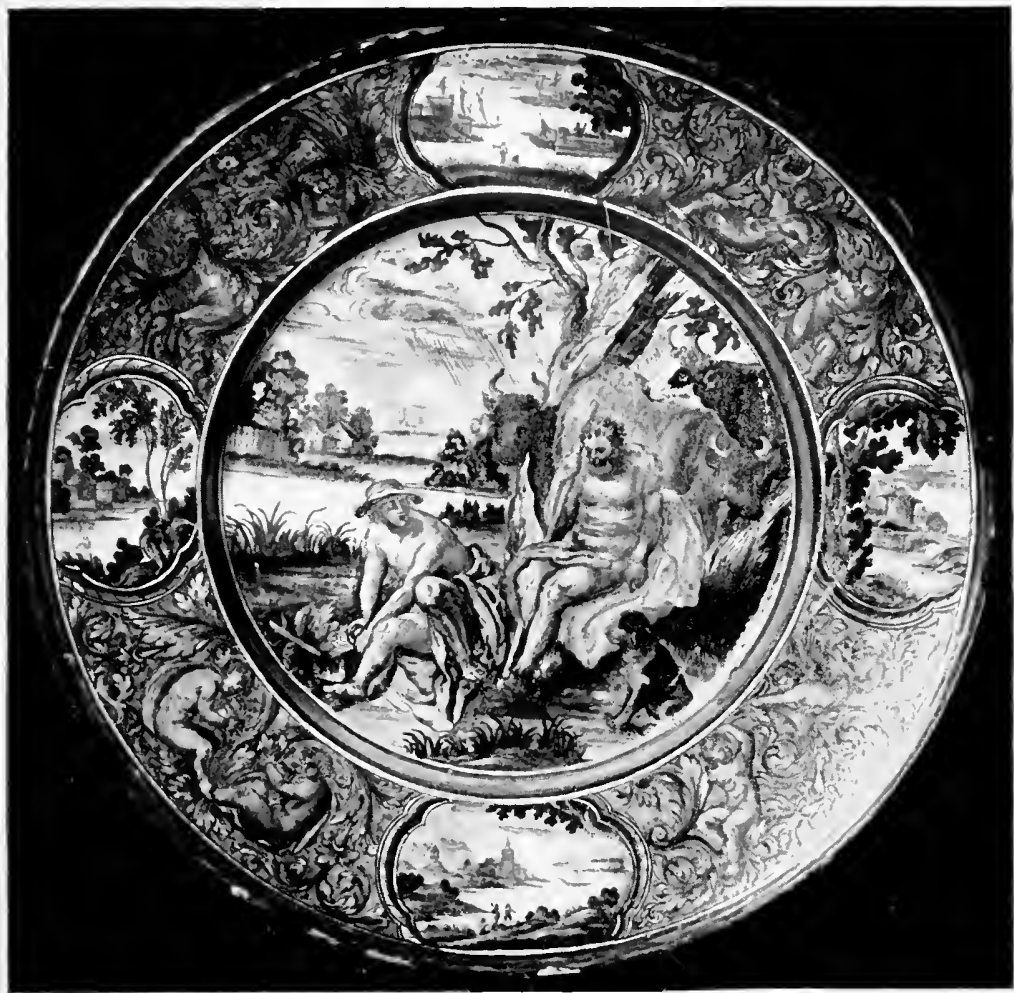

D. $16^{\prime \prime}$

[Ploto, D. Freuler, Paris

DISH, of Nevers Faience. Sèrres Museum. 



\section{FAIENCE : NEVERS}

in manganese; flesh is modelled in light or dark shades of yellow; the setting of the subjects is sometimes a landscape, sometimes the sea-shore; the execution is broad, the drawing pure in line, the colour charming, but the inspiration is almost entirely Italian.

The second period, on the contrary, drew its inspiration from elsewhere. For the sake of clearness we will divide this second period into three separate categories, and we shall find first of all a certain number of works labelled as in the Persian style (goutt Persan). This Persian style evolved itself at Nevers in three different forms: a certain number of examples are coloured in a very rich azureblue, relieved by designs in iridescent whites and yellows. As on the ceramics of Persia, we find tulips, pinks, birds, and plants; figures and landscapes are the exception. This ware, so long classed among the productions of the East, has only somewhat recently been assigned to Nevers. It was of fairly quick and easy manufacture, and hence examples are more common than those of the first period.

This Persian style again manifests itself in pieces of a dull yellow tint relieved by a little 


\section{FRENCH POTTERY \& PORCELAIN}

white, such as the pouch-shaped bottle in the Sèvres Museum; and yet again in others where the decoration is carried out upon a ground of white enamel-some polychromous, and some in blue camaieu: see the bottles and vases of the Louvre, the drug-vase, and finally the fine "David and Bathsheba" dish in the Sèvres Museum.

After having been subjected to the influence of Persia, Nevers next passed under that of China and of Japan. Porcelain from those countries had already been imported into France during the sixteenth century, but did not become common until the seventeenth. Nevers produced extremely clever imitations of it, in such numbers that they are frequently to be met with at the present day.

The Franco-Nivernese style constitutes a fresh period. While previous achievements had borrowed much from mythology, these, on the contrary, sprang from more national sources. In the matter of subject this period is the most original of all; though many details remain resolutely Persian in style, and the embroideries of Rouen or of Moustiers, and even the flowers of Saxony, intrude themselves among subjects chosen from the 26 


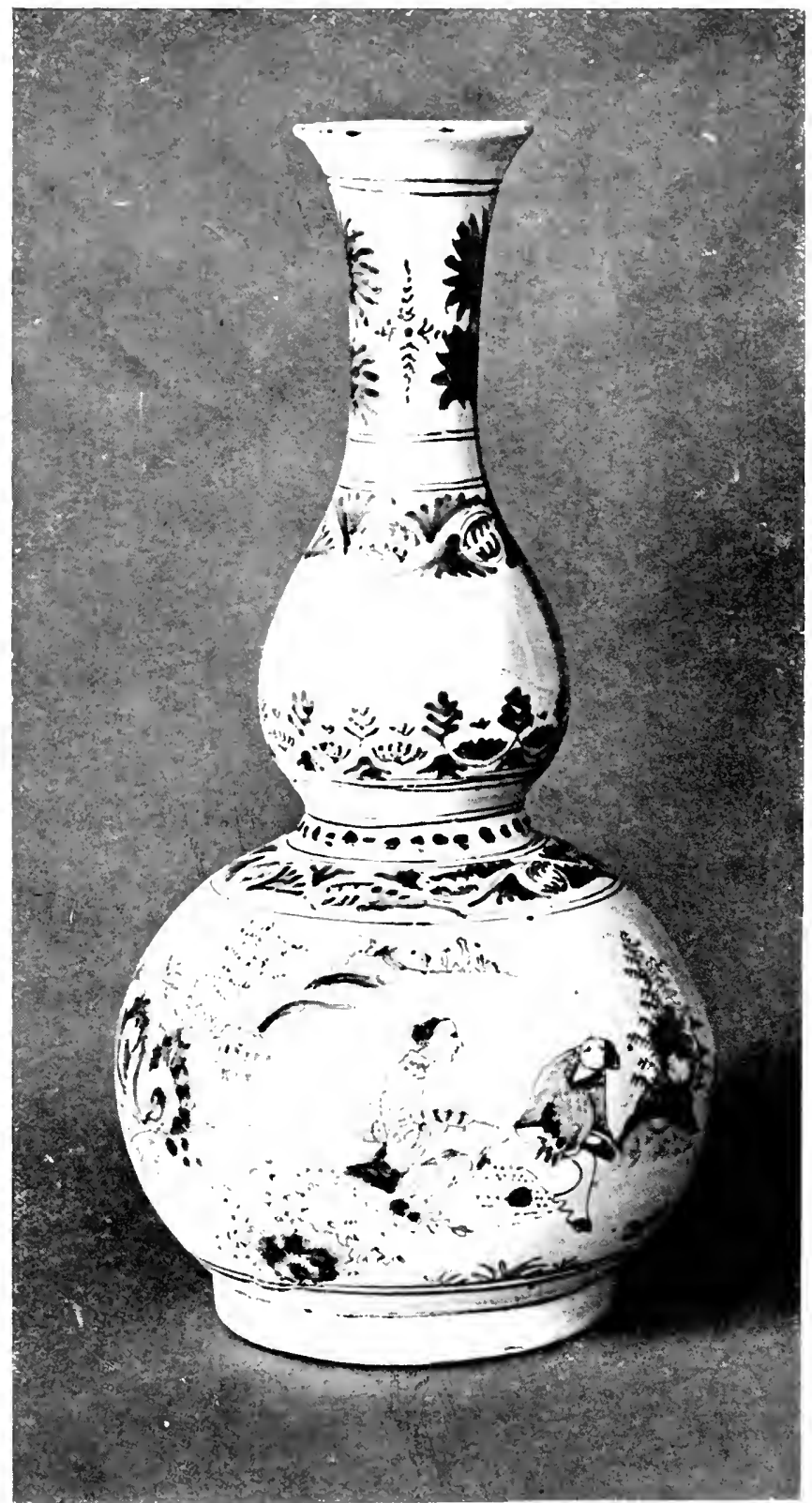

H. 15:" D, hase 5!'

VASE, of Nevers Faience. Sonth Kunsington Musenm. 



\section{FAIENCE : NEVERS}

primitive French sources of the time. "We have come," writes M. Gouellain, "to an epoch in the history of art the traditions of which continue in force until the middle of the eighteenth century. Naiads, artistically descended from those of the Farnesina frescoes, alternate with Dutch drinkers in the decoration of comparatively large pieces. Now masks or rams' heads stand out from the pediment of some colossal fountain or ornamental vase; now pot-bellied Chinamen strut about on wide-brimmed dishes, recalling with more elegance and less monotony the favourite style of Delft."

After this period of original production Nevers relapsed into imitation. She now copied Rouen ; and we may see in the Museum of Nevers various pieces decorated in blue, en camaieu-flagons, drug-vases, Chinese vases, and aiguieres - which servilely imitate the blue en camaieu ornamentation of Rouen.

Nevers also imitated the cornucopia decoration of Rouen, but, as she possessed no red, with little success; on the other hand, the imitations of the en rocaille ornamentation with birds, butterflies and flowers, are of quite first-rate quality. Next, workmen who came to Nevers from Moustiers about I735 produced wares 


\section{FRENCH POTTERY \& PORCELAIN}

distinctly inspired by those of their native place. Pieces of this type are to be seen in a service executed for the faience-manufacturer Charles de Pryne of Chazelles. To the imitation of Moustiers succeeds that of Saxony: the great épi of the Nevers Museum, with its flowers in relief and its ornamental grace, affording proof of this; as do also a number of small commodes and baskets for fruit.

But little by little Nevers fares towards decadence. The plates of the Revolution, on which the emblems of the clergy neighbour those of royalty, of the nobility, and of the people, form documents often interesting from an historical point of view, but that in no way recall the fine production of preceding epochs. At last the Revolution dealt Nevers a final blow: in consequence of a treaty concluded with England in I789 English pottery was introduced into every part of France, and by its cheapness killed the productions of the ancient town of the Conrades, of the Custodes, and of Claude Levesque. 


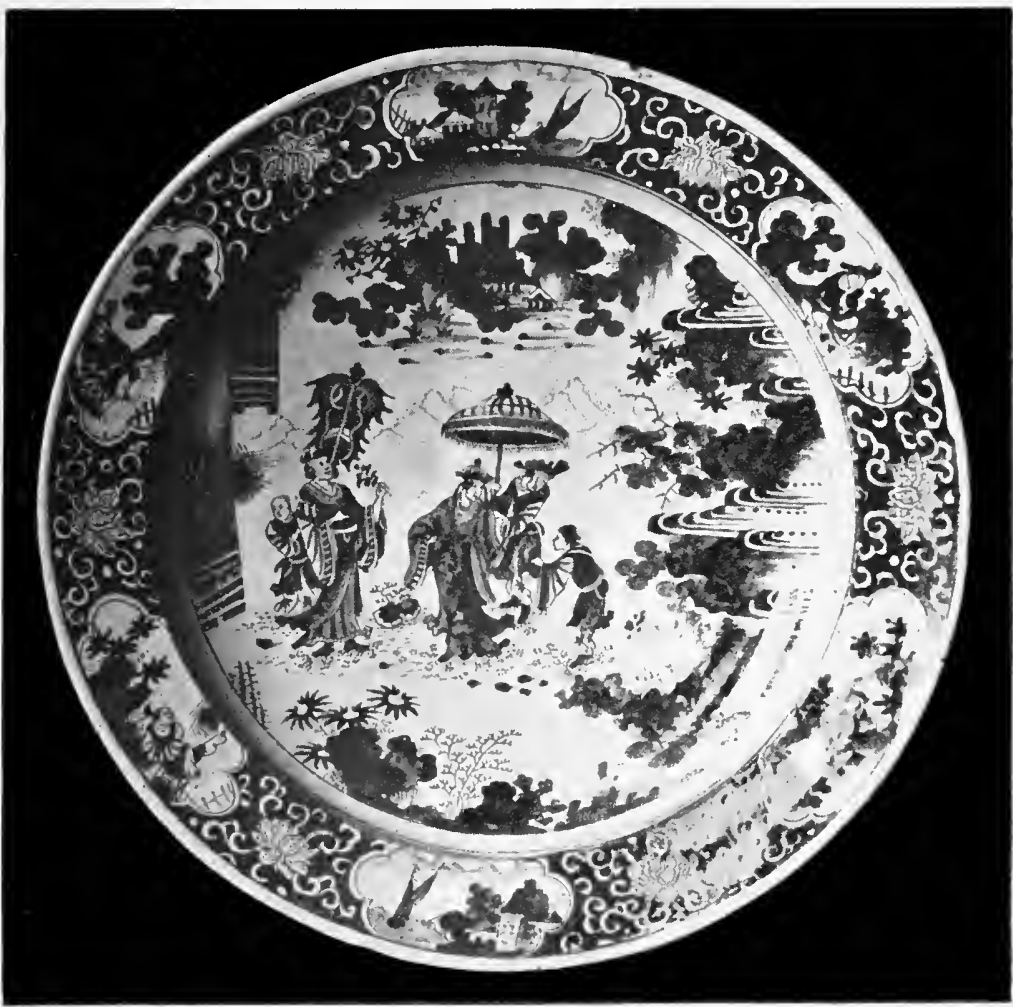

D. $22^{\prime \prime}$

BASIN, of Nevers Ware. South Kensington Museum. 




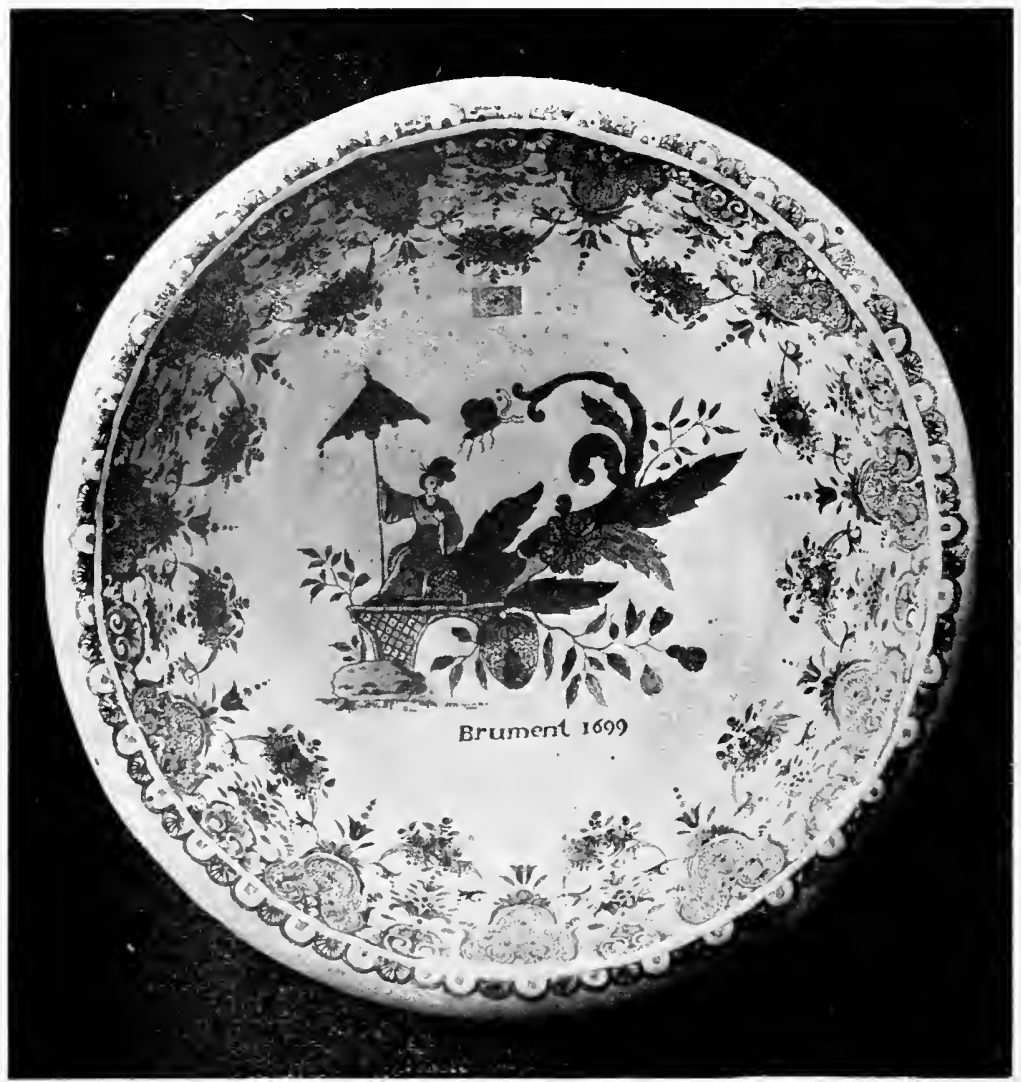

D. $12 \frac{1}{2} "$

[Photo, Petiton, Rouen

DISH, of Rouen Faience (manufactured by Brument). Polychrome. Rouen Museum. 
THE FOURTH CHAPTER

\section{FAIENCE: ROUEN}

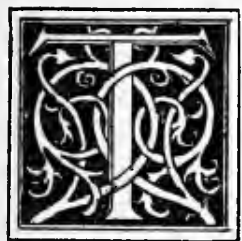

HE productivity of Rouen's manufactories has been so great, the pieces that have issued from them are so numerous and so diverse, that learned archæologists like Ris-Paquot or André Pottier have devoted to this fine subject entire books in which every phase of the manufacture has been studied and analysed down to the smallest details. M. Gaston Le Breton has also published valuable studies on the ceramics of the great Norman city. These notable specialists I therefore recommend to all who desire to make a serious study of this interesting subject.

But first of all they must be advised to visit the fine ceramic museums of Rouen or of Sèvres, in which we can follow step by step the history of this fascinating art. We have seen that after Abaquesne all ceramic production ceased in the Norman town. It was not until more than eighty years later than Nicolas Poirel, Sieur de Grandval, 


\section{FRENCH POTTERY \& PORCELAIN}

usher to the queen, obtained the right for fifty years to make and sell faience in Normandy; but this right could not be completely exercised until I648, Parliament having refused to register the Act. Poirel, meanwhile, had soon ceded it to Edme Poterat, and the latter had already made his workmen execute several pieces while awaiting the Parliamentary authorisation. Such, at least, is the opinion of Garnier, who very reasonably bases it on a vase in the Rouen Museum which bears the words "Faict $\dot{a}$ Ronen en 1647." The first workmen at Rouen had come from Nevers; it is, therefore, only natural that the first productions should show rather markedly the ItaloNivernese influence. Like Nevers, Rouen began by producing dishes and plates, the form of which recalls that of the Italian tondini; they are decorated in blue, en camaieu, with monsters, birds, and flowers. But now appears the difference between Nevers and Rouen, and the latter's incontestable superiority: while Nevers always copied, Rouen on the contrary copied only during a very short time at the outset, and quite occasionally afterwards. She soon 30 


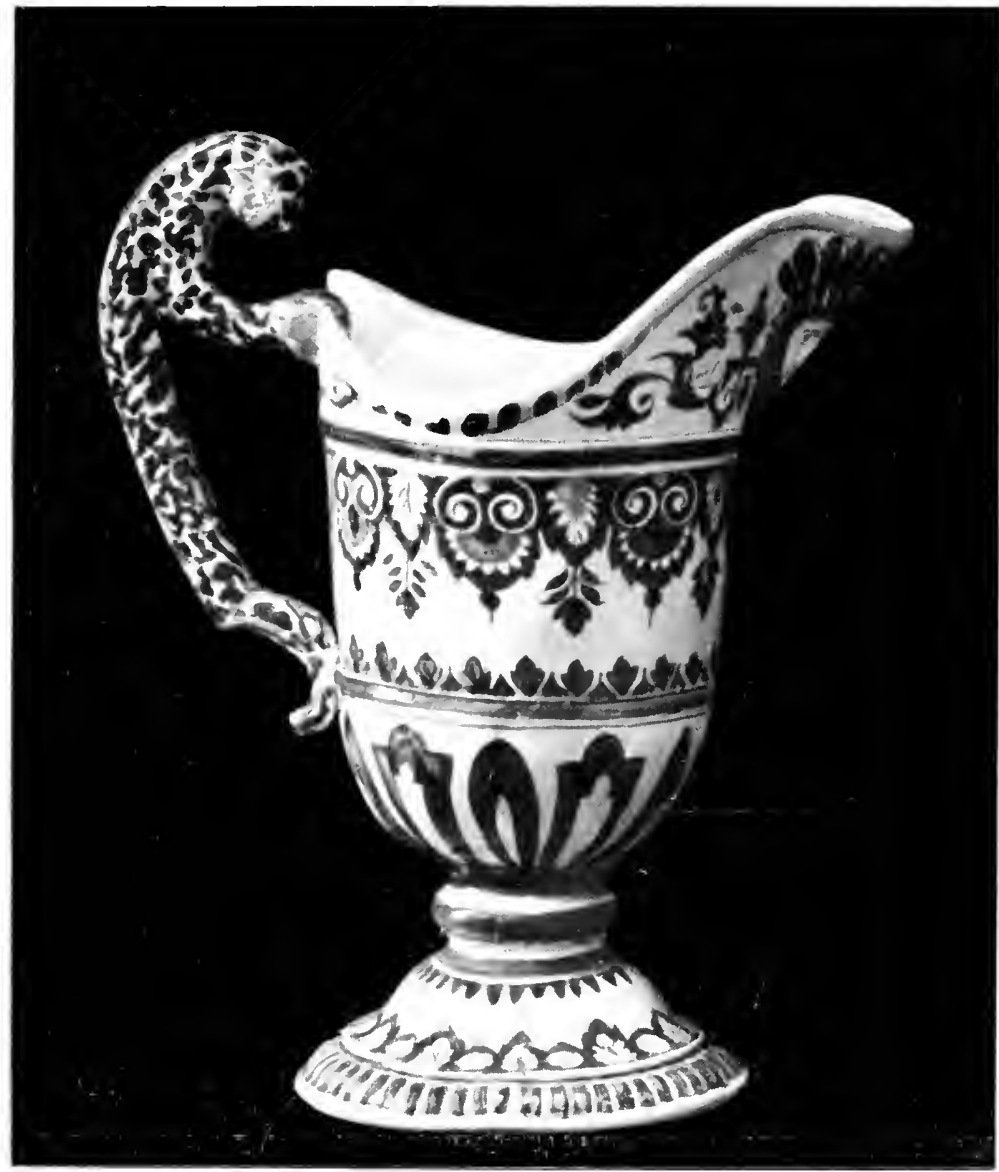

\section{11}

LHoter, I'titun, Rulich

EWEK, of Roun Faince. Romen Musemm. 



\section{FAIENCE : ROUEN}

forgot the Nevers style of ornamentation, to create-in the end of the seventeenth century - the beautiful scalloped decoration, "the alternating motifs of which," says Garnier, "were borrowed for the most part from stuffs, laces, marqueterie, ironwork, or from tail-pieces in the fine books of the period."

The cause of the rapid development of the manufacture of pottery and porcelain at both Rouen and Moustiers is to be found particularly in the sumptuary laws, which at that time bore hardly upon silver-work. War, floods, and famine had exhausted the exchequer at the beginning of the eighteenth century, and to assist the treasury some of the nobles took their silver plate to the mint and had it melted down. Louis XIV.'s sister-in-law, the Duchess of Orleans, writes in I709: "The famine is such that children have eaten one another. The king is so determined to continue the war that he yesterday replaced his gold plate by a service of faience; he has sent to the mint everything of gold that he possessed, to be converted into louis." Saint-Simon confirms this fact in his memoirs: "All that was of great or 


\section{FRENCH POTTERY \& PORCELAIN}

considerable valuable was replaced by faience within a week ... they emptied the shops ... the king sent all his gold plate to the mint, and Monsieur the Duke of Orleans sent the little he possessed."

Edme Poterat was the first to do work for the Crown; he died in 1687 , possessing the title of Director of the Faience Manufactures of Rouen. As early as 1673 he had established a factory in the Faubourg de SaintSever for his son Louis, who soon became his competitor. Colbert obtained for Louis a royal licence, which it will not be without interest to quote here :

"Our well-beloved Louis Poterat has very humbly made known to us that through travels in foreign lands and by constant application he has discovered the secrets of making the true porcelain of China and the faience of Holland; but, it being impossible to him to make the said porcelain except conjointly with the faience of Holland, because the porcelain cannot be baked unless it is entirely covered, so as not to receive the violence of the fire, which ought to be moderate in its heat, it is necessary for him to have our permission to work and to 


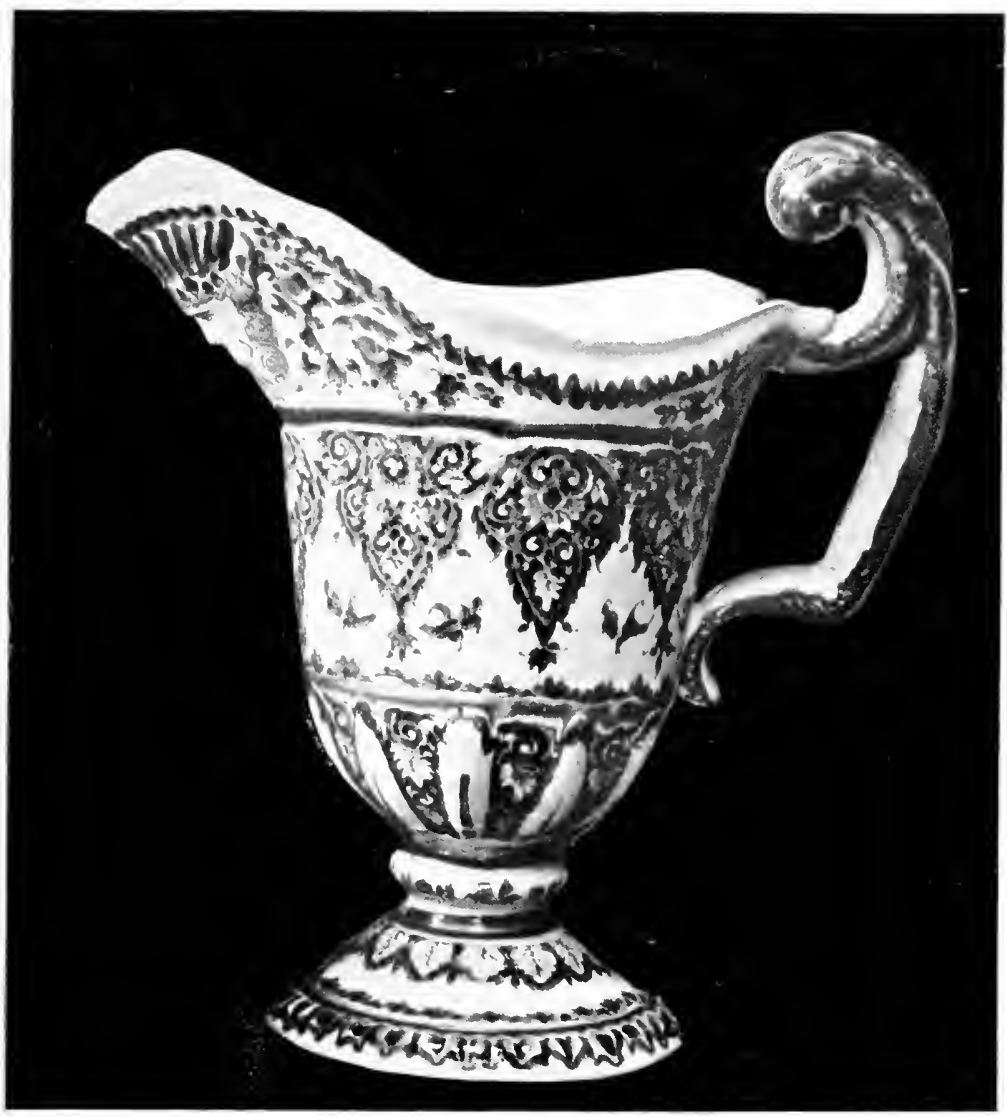

H. $11^{\prime \prime}$

[Photo, Petiton, Rousn

EWER of Rouen Faience Rouen Museum. 




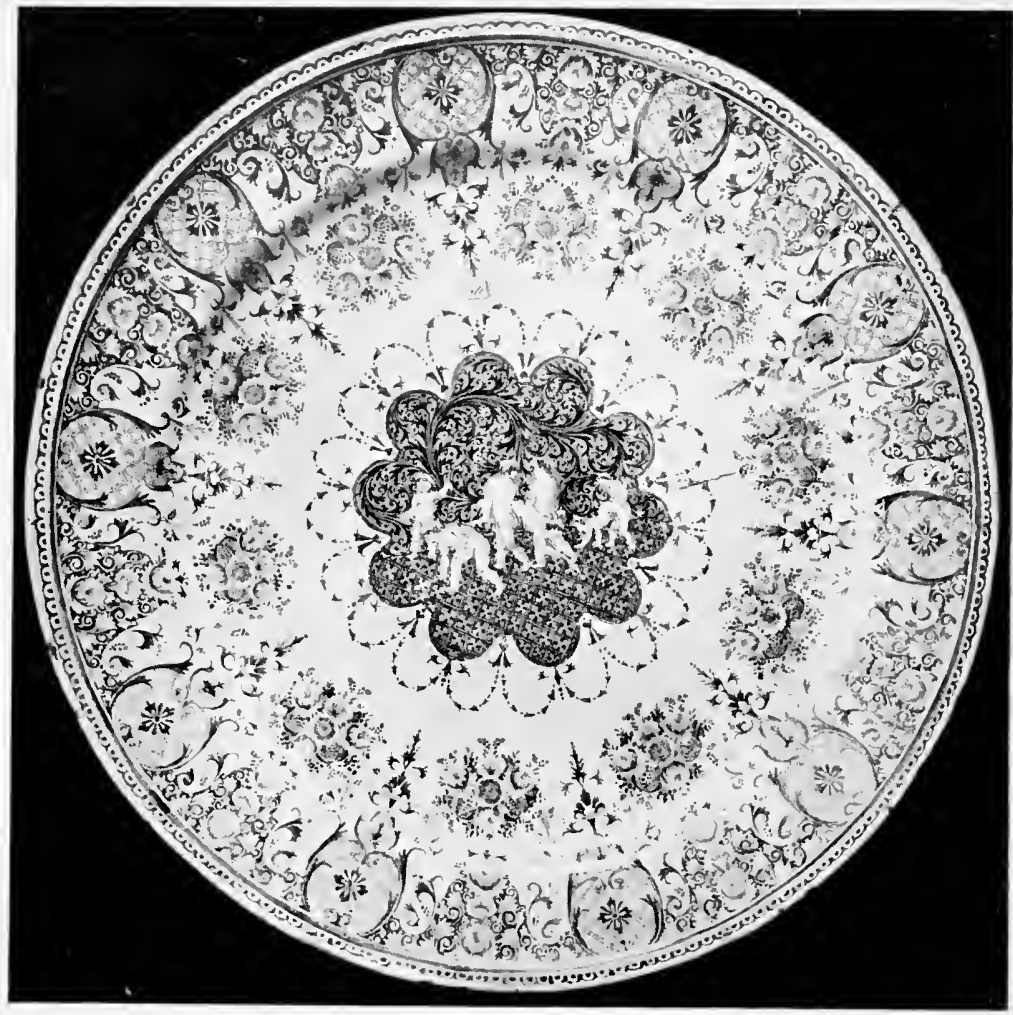

D. $22^{\prime \prime}$

[Photo, Petzton, Ronen

DISH, of Rouen Faience, Polychrome. Rouen Museum. 


\section{FAIENCE : ROUEN}

employ labour on both the one and the other, and for this end to construct great furnaces, mills, and workshops in places proper for such work, and those which appear to him the most convenient are in one of the suburbs of Rouen called Saint-Sever, where a manufactory of the said works can be established, to make there all sorts of vessels, pots, and vases of porcelain similar to those of China and of the violet faience painted in white and in blue and in other colours in the fashion of that of Holland, for such time as shall please us, during which he may sell and retail the said porcelain and faience as above, without let or hindrance, and to this end he prays us very humbly to accord him the necessary letters.

"For these reasons, and desiring favourably to treat the said petitioner in order to oblige him to work, from better to better towards the perfection of the said work, WE, of our special grace, full power, and royal authority, have, by these presents signed by our hand, permitted, granted, and accorded, do permit, grant, and accord to the said petitioner to establish in the Faubourg Saint-Sever and in all places in our kingdom as may seem good to him, a manufactory of all sorts of vessels, 


\section{FRENCH POTTERY \& PORCELAIN}

pots, and vases of porcelain similar to those of China, and of violet faience painted in white and in blue and in other colours like that of Holland, to employ the labour of such number of persons as he judges necessary, and for this end to build furnaces, mills, and workshops proper for the said porcelain and faience, which the said petitioner may sell throughout our kingdom for the term of thirty years, during which we have expressly forbidden and do forbid all persons to let or hinder him in the establishment and manufacture of such work and sales under penalty of a fine of one thousand livres, all costs, damages, and interests, notwithstanding the prohibitions contained in our letters accorded to Nicholas de Poirel, Sieur de Grandval, the 3d. September I646, to which we have derogated and do derogate, and wish to make unable to injure the said petitioner for the execution of these presents.

"Given at Versailles (October I673)."

Royal favour thus brought about a fertile rivalry among the factories of Rouen, which were very numerous at the end of the seventeenth century, though their productions are somewhat difficult to distinguish one from 34 


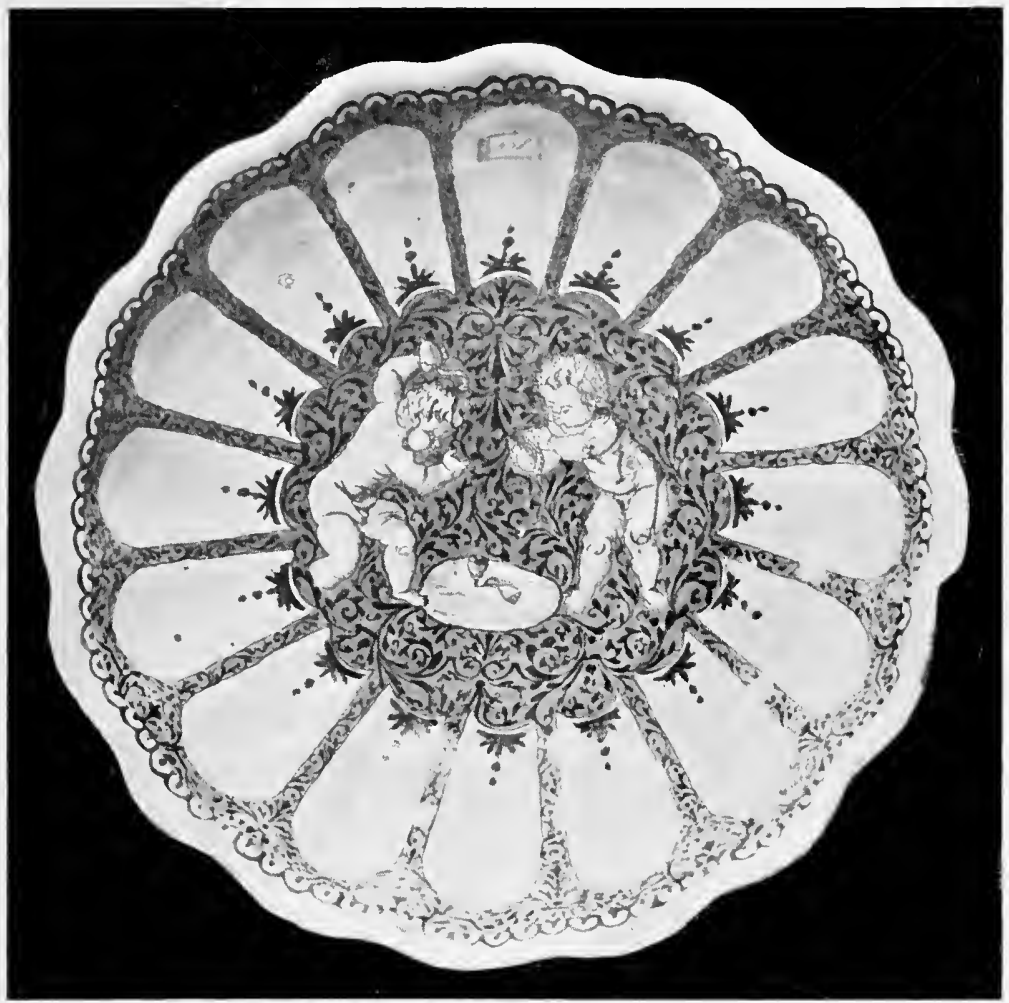

D. $10 \frac{1}{4}$

[Photo, Petiton, Rouen

DISH, of Rouen Faience. Rouen Museum. 




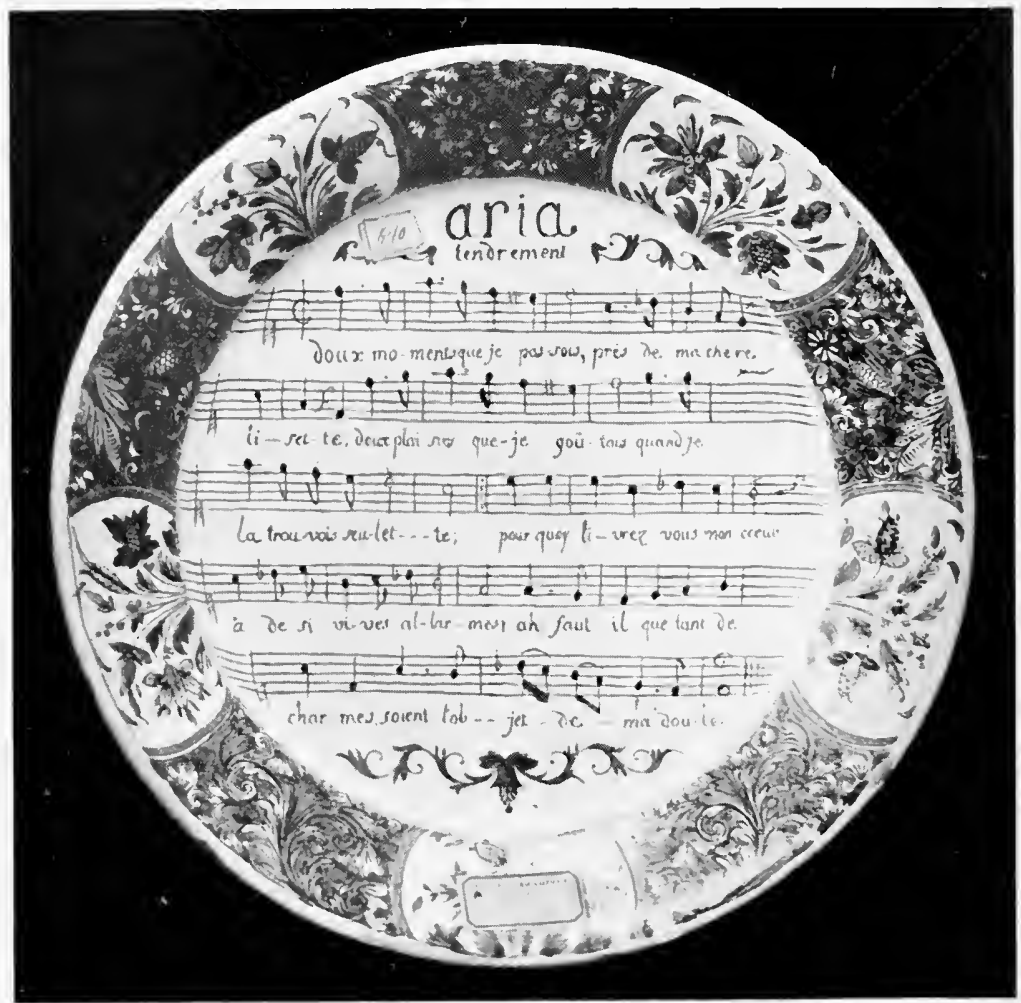

$$
\text { I. } 9^{3 \prime \prime}
$$

[Photo, Petiton, Rourn

PLATE, with Music Score. Only a few Specinens of these Plates are known, two of which are in the kouen Museum. 


\section{FAIENCE : ROUEN}

the other. In 1720 , according to a return preserved in the departmental archives, eight ceramic factories were counted in Rouen: Bertin, Touquay, Dame de St. Etienne, Caussy, Heugue, Bréard, and Cauchois, being the principal ones.

Twenty years later there were eleven: Touquay, Veuve Huet Bertin, Veuve Loüc Guillibaud, Fossé, Nicolas Malétra, L. Sulmont, Guillaume and François Heugue, Flandain, Pierre Paul Caussy, M. Macarel. In 1755 there were thirty factories; in 1788 fifty, among them the famous Levavasseur; in I798 eighteen; at the end of the century seventeen; in 1802 seven. A curious circumstance is that many of these manufactories were directed by women.

Among the workmen employed at Rouen were a certain number who had come from elsewhere, but these were a small minority. Some were English, some Flemish. It is not without interest to note that among the workmen's names is to be found that of Fouque, doubtless a relation of the Fouque who owned a factory at Moustiers.

After some imitation of Delft the true 


\section{FRENCH POTTERY \& PORCELAIN}

Rouen style appears for the first time in a piece signed "Brument I699." M. Darcel, in his "Guide de l'Amateur de Faiences" gives the following general description of the Rouen ornamentation:-

"These are conventional and symmetrical designs," he says, "forming scrolls or scallops, which, symmetrically distributed over the surface of the pieces, radiate around the centre in the case of dishes and plates, or descend from the brim and cover the body in the case of vases. This style of decoration is generally blue on white enamel."

It is so invariably in the early examples of the manufacture. And let us note here how purely decorative in form is this Rouen type of ornamentation; while on the other hand Strasburg, Sévres, Marseilles, and other centres offer us almost literal reproductions of flowers and other natural objects.

Decoration in polychrome did not begin till some years later, towards the end of the seventeenth century; its designs were invariably constructed of the same arabesques, arranged in infinite variety. Afterwards came the décor a ferronerie, so called because it 36 


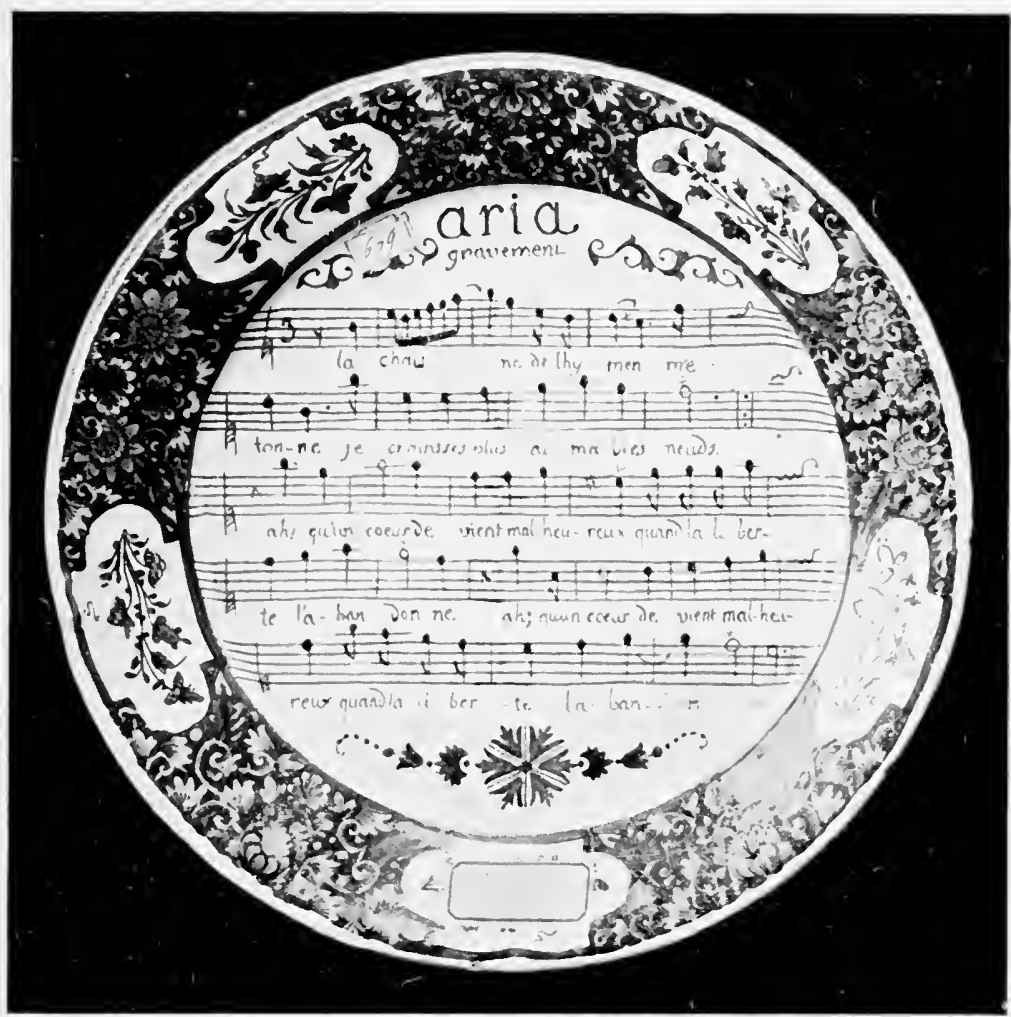

D. $9 i^{3 \prime \prime}$

[Photo, Petiton, Rowen

PLATE, in Rouen Faience. Rouen Museum. 




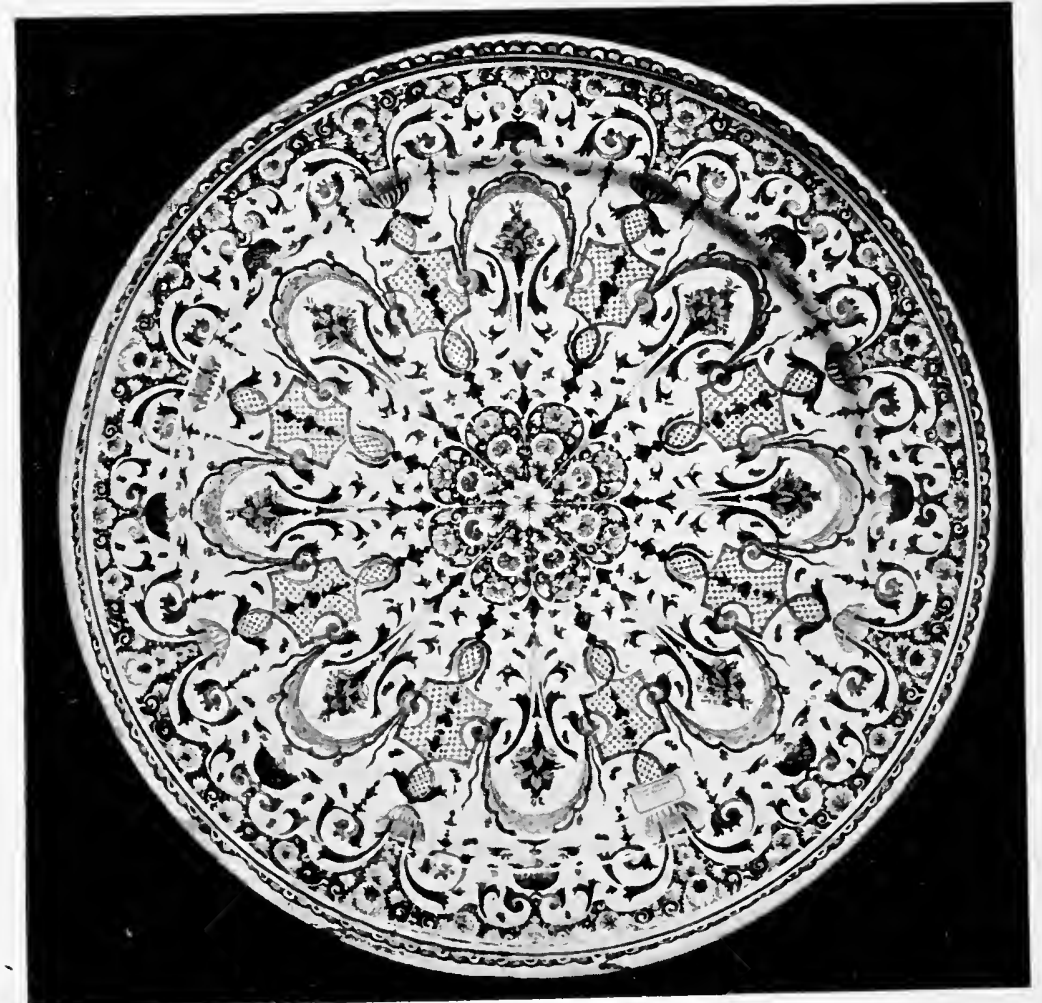

$$
\text { 1). } 21^{3 \prime \prime}
$$

[Photo, Petiton, Rouen

PLATE, of Rouen Faience. Rouen Museum. 


\section{FAIENCE : ROUEN}

imitated the fine achievements in wroughtiron of that period.

One of the most remarkable examples of multi-coloured decoration of the first period was the service ordered by Henri de Montmorency, Duke of Luxemburg, and attributed to the Guillibaud manufactory. Many specimens of this are at Cluny.

The years from 1700 to 1750 were the triumphal period of ceramic art in Rouen, freed as it was from the tyranny of special privileges by a decree of 1617 . Nowhere else in France has the output ever been greater or more varied; which explains the fact that despite their fragility and their great vogue many pieces of Rouen ware still pass through the market. The following were the principal categories of objects issued from the numerous manufactories of the Norman town: Tableservices plain or ornamented, soup-tureens, large dishes, busts of various sizes, pedestals and consoles, stoves, chimney-pieces, decorative pictures composed of painted panels, garden-urns of all sizes, drug-vases, ornamental vases, church-lamps and altar-vases, inkstands of different designs, wine-coolers, épergnes, writing-desks with drawers in 


\section{FRENCH POTTERY \& PORCELAIN}

faience, snuff-graters, holy-water stoups, flat candlesticks, hand-candlesticks, trays with feet, teapot-stands, wall-fountains with their basins, scent-bottles, lanterns, little shoes and slippers, jugs and bottles, little figures of Bacchus upon a barrel, bottles in the form of books, snuff-boxes, dial-cases for watches, solar meridians, terrestrial globes, crucifixes on stands, little boxes, castors for powdered sugar, garden-lions, bouquets of flowers and of fruit, plates with fruits in relief, snuff-boxes in the shape of books, weather-cocks, milkpans, patch-boxes, pictures of the Crucifixion, music-desks.

Large pieces, such as the magnificent busts at the Rouen Museum, are naturally rarer than the others. Of the same manufacture we must also mention the pavements of painted tiles, hardly any of which are known save those of Villeray, near Bolbec. They are of uniformly square tiles, forming a radiating and interlaced design. The central rose is formed of eight motifs composed of interlacing bands of foliage. Sometimes, too, the faience-makers executed inscriptions to perpetuate the memory of certain events; such an inscription is still to be seen on a house 38 


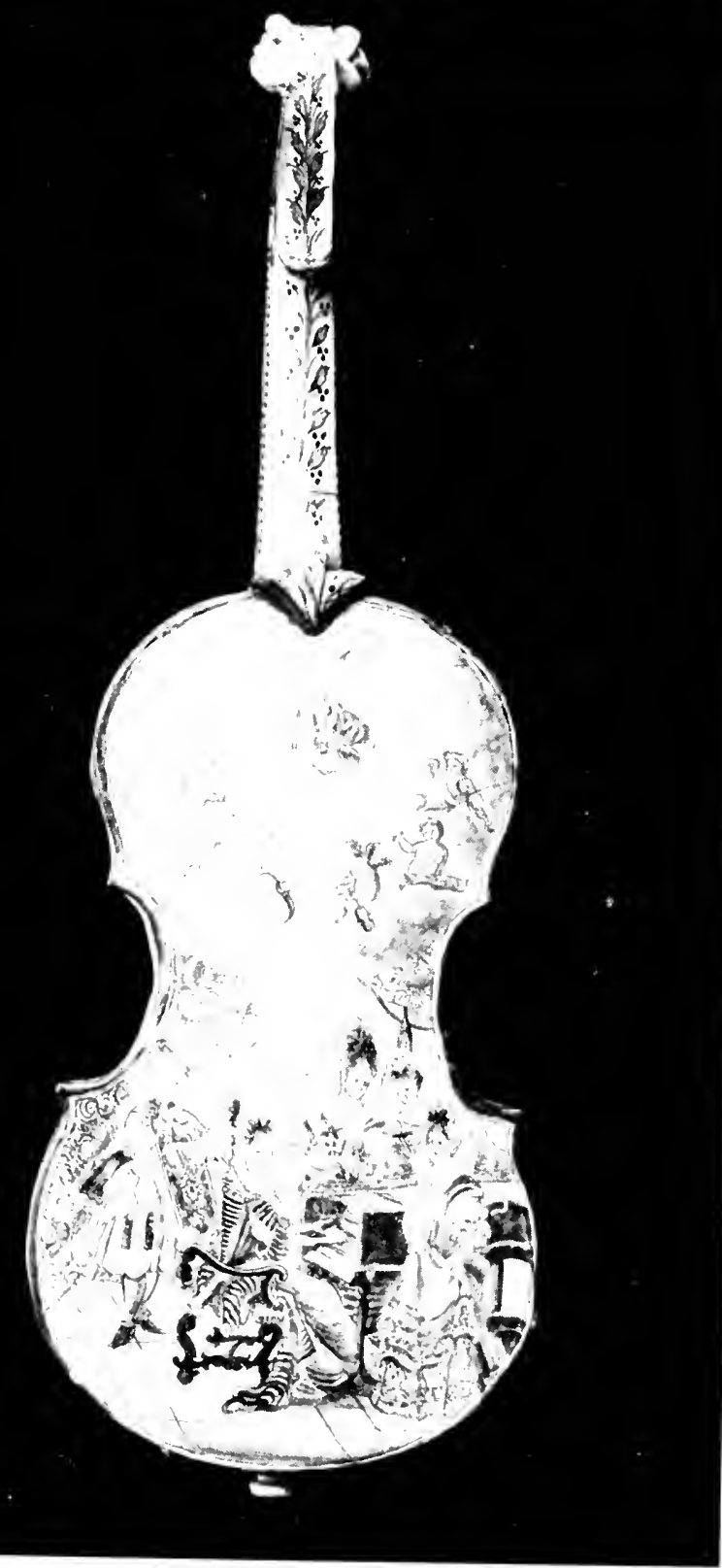

11. 23 !

THE FAIENCE VIOLIN. One of the Masterpieces of kinten Faience. 




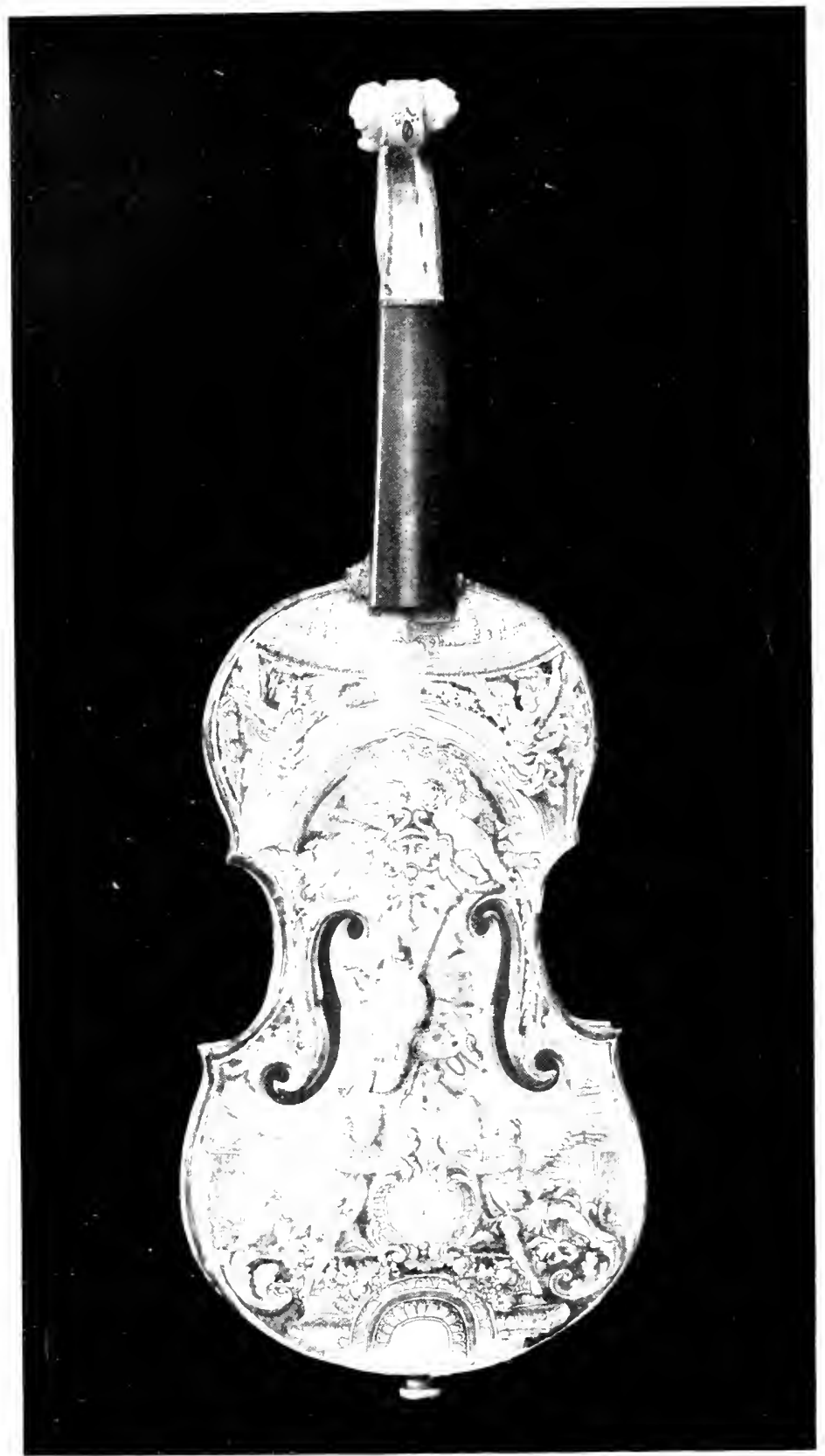

H. 231

I Phathertion, Rolith

THE IALXCI VIULI. 


\section{FAIENCE : ROUEN}

recording the casting of the bells of the church of St. Sever in I758:

Astonishment is often expressed at the large size of the dishes, which are sometimes as much as 57 or 58 centimetres in diameter. Such dishes were passed from one guest to another, and held meat for 18 to 20 persons. This custom of overloading dishes dated from an ordinance of Louis XIII. forbidding the possession of more than one complete service and one row of dishes.

Among the most important masterpieces executed by the faience factories of Rouen are the famous celestial and terrestrial globes, the work of Pierre Chapelle, which may be admired to-day in the Rouen Museum. The celestial globe is decorated with designs representing the four elements, the terrestrial globe with designs representing the four seasons-unique pieces of incomparably beautiful material. The paintings are en camaien slightly relieved by colour. Each piece is composed of four separate layers. The base is formed by four lions. The frame is composed of four reversed consoles, forming horizontally a sort of $X$. The crowning piece bears at its corners heads symbolical of 
FRENCH POTTERY \& PORCELAIN

the four winds. Upon the work is to be seen the following inscription:

\section{A ROUEN \\ . $\mathrm{7} 725$. \\ PEINT PAR \\ PIERRE \\ CHAPELLE}

Like Moustiers and Marseilles, Rouen utilised the Chinese style of decoration on pieces of considerable beauty, the best of which issued from the Guillibaud factory; but still more beautiful are the pieces with figure subjects. Among these are some which are polychromatic: Adonis surprising the sleeping Venus, Judith and Holofernes, Jesus and the Woman of Samaria, the triumph of Cybele; then there are other pieces in blue camaieu: Danae and the golden rain, and St. John baptizing on the banks of the Jordan-an important composition comprising about twenty figures. The best-known designers of these were Claude Borne and Leleu.

Among the rare examples of the best Rouennese period, we must not forget those fine pieces adorned in the centre by great medallions with lobed borders, and a back40 


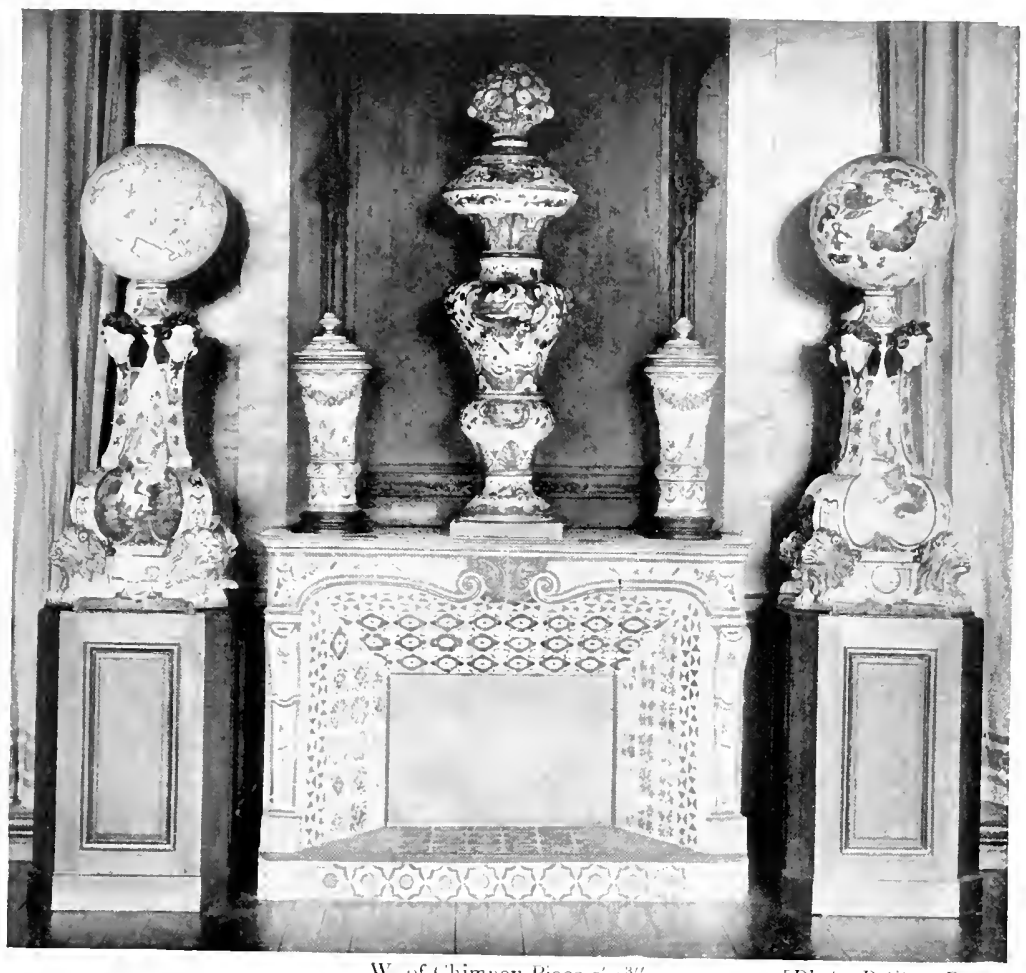
A CORNER IN THE ROUEN MUSEUM, showing the famous
Celestial and Terestrial Globes. 




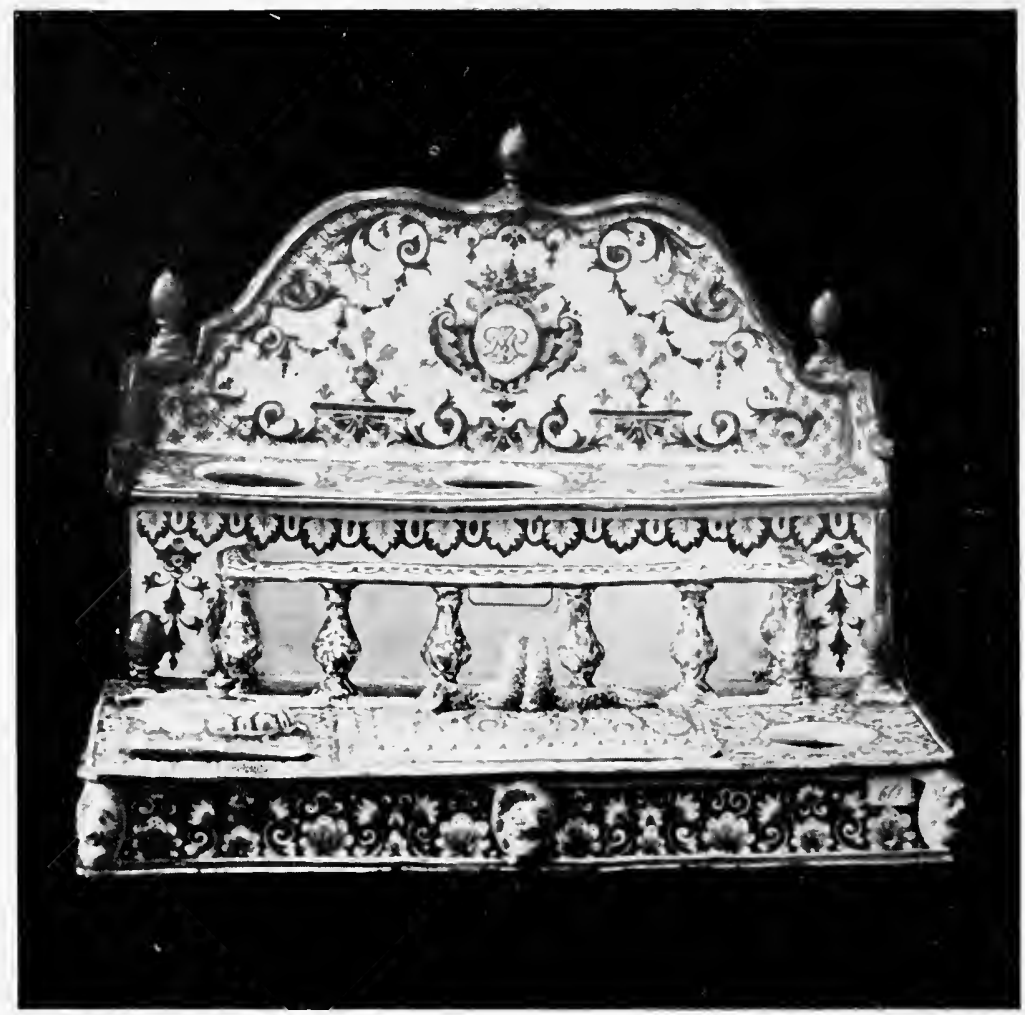

H. 9 मे $^{\prime \prime}$

[Photo, Fe'iton, Rouen

INKSTAND, of Rouen Faience. Ronen Museum. 


\section{FAIENCE : ROUEN}

ground of ochre yellow, upon which exquisite figures of Cupids stand out in dark blue, surrounded by arabesques; nor the decorations in lapis lazuli blue, in the style of Persian ceramics, with flowers and insects; nor again that unique specimen, the famous violin in ceramic of the Rouen Museum, and the plates with musical inscriptions on them, of which only a few examples are known.

Towards the middle of the eighteenth century we note the appearance of ornamentation en rocaille, consisting of quivers and flaming torches, represented with that superb polychrome for which Rouen was noted. These pieces are fairly numerous, but much sought after. Yet more so is a style of decoration examples of which are still pretty frequently in the market: the décor à la corne, or cornucopia ornament. Judging by the number of examples preserved in museums and collections, this style always enjoyed a great vogue. In France, at the present day, plates with the ordinary cornucopia fetch $£^{2}$ to $£ 3$ apiece; but I need hardly warn amateurs against the frequency of imitations. Plates with 


\section{FRENCH POTTERY \& PORCELAIN}

the radiating decoration fetch on an average $£ 25$ apiece.

For a long time past, fine examples of Rouen ware have commanded very high prices.*

To define clearly the different varieties of the Rouen manufacture, we append the classification of M. André Pottier :

First attempts $\left\{\begin{array}{l}\text { Nivernese influence } \\ \text { Dutch influence }\end{array}\right.$

Radiating style $\left\{\begin{array}{l}\text { Decoration in blue camaieu } \\ \text { Decoration in blue relieved by blue } \\ \text { and red } \\ \text { Regularly polychromatic decoration }\end{array}\right.$

Chinese imitation $\left\{\begin{array}{l}\text { Checkered borders } \\ \text { Pagodas }\end{array}\right.$

\section{Exceptional Pieces}

En rocaille style $\left\{\begin{array}{l}\text { Scenes of gallantry or rural life } \\ \text { Trophies, quivers } \\ \text { Cornucopias, single flowers }\end{array}\right.$

Porcelain . Imitations of Strasburg and of Marseilles

* See Chapter XI. 

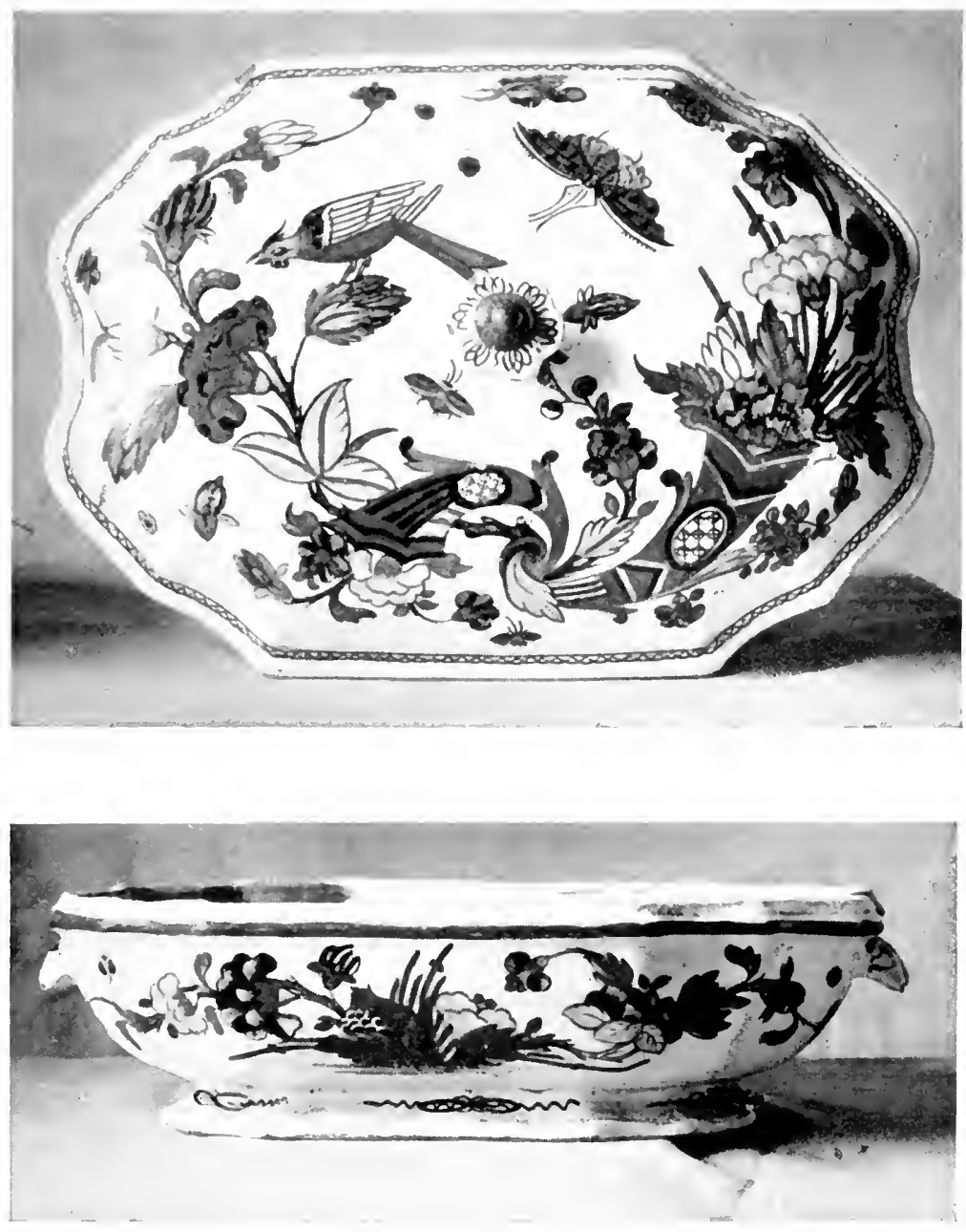

I.. $134^{\prime \prime}$ H. $4^{\prime}$

LPhoto, D. Freuler, Paris

SOLP TUREEN, of Rouen Faience. Polychrome

Collection Fritsch-Estrangin. 

THE FIFTH CHAPTER

FAIENCE : MOUSTIERS

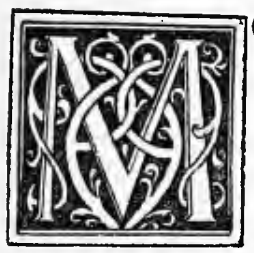

OUSTIERS and Marseilles together constitute the great centre of ceramic manufacture in the South of France. Hitherto the productions of Moustiers have in general been preferred to those of Marseilles; they are more valued by amateurs, and fetch higher prices in public sales. I believe, however, while fully doing justice to the magnificent specimens bequeathed to us by the famous faience factories of Moustiers, that a revulsion will take place in favour of the faience of Marseilles-a revulsion which has, indeed, already set in, witness the prices reached by Marseilles faience during the last few years. Like Nevers and Rouen, Moustiers not only produced admirable faience during over a century, but also exercised an important influence on the manufactures of Southern France, and still more on those of Spain; to Moustiers alone, in fact, we owe the inception of the Alcora factory, of which I 


\section{FRENCH POTTERY \& PORCELAIN}

shall speak by-and-by. Moustiers was frequently imitated, moreover, both by Nevers and by Rouen.

There are two theories as to the date when the manufacture of faience upon white enamel began at Moustiers. Baron C. Davillier, in his little book, "Histoire des Faiences et Porcelaines de Moustiers, Marseille et autres Fabriques Méridionales" (Paris: Castel, I853), maintains the view already set forth by Dr. Bondil of Moustiers. Bondil says that at the beginning of the eighteenth century a monk in a Moustiers monastery imparted to Pierre Clérissy the method of producing an opaque white enamel for covering pottery. M. E. Fouque, on the other hand, attempts to prove in his learned studies of the faience of Moustiers, that as early as 1686 Clérissy discovered and practised the art of covering pottery with white enamel and then decorating it afterwards with paintings in blue. This Pierre Clérissy assumed thenceforward the title of master-faience-maker. This theory is very exactly stated, and the letters of Madame de Sévigné constitute a document witnessing in its favour. Madame de 44 


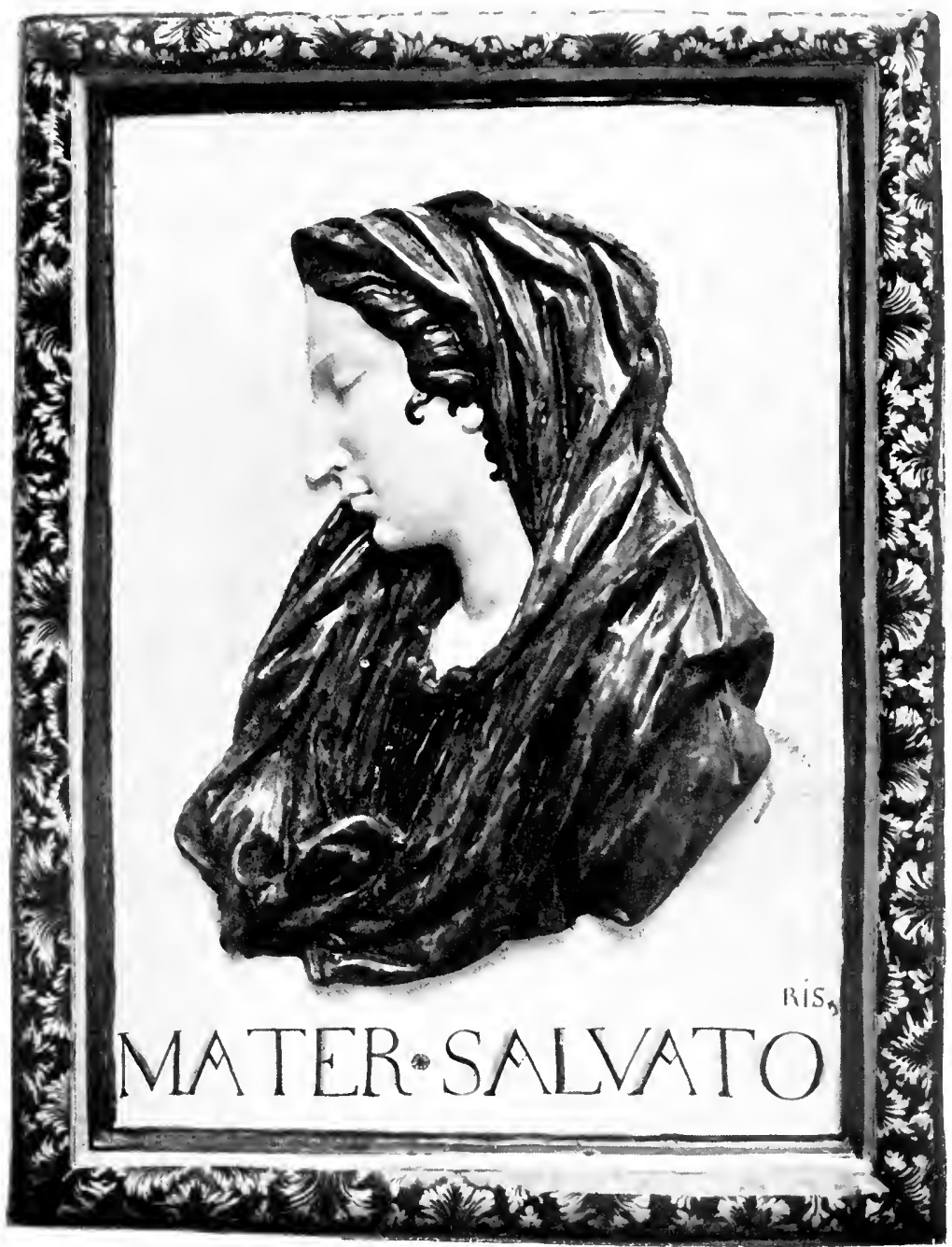

H. $30^{\prime \prime}$

BAS RELIEF, in old Moustiers Faience, Polychrome. End of XVII century. Museum of Château Borély at Marseilles. 



\section{FAIENCE : MOUSTIERS}

Sévigné resided in the Château de Grignan, the picturesque ruins of which are now owned by the Comte de Castellane, and she was constantly travelling about that part of France. In one of her excursions she visited Lambisc, the meeting-place of the Provençal Parliament, and mentions a repast the service for which was made of the fine faience of Moustiers. Now, as her last journey in Provence took place in 1694, it is obvious that the manufacture of the white enamel of Moustiers must have commenced several years previously, in order to have reached such perfection as to win the admiration of a woman accustomed to all the sumptuousness of Louis XIV.'s court.

At about the same time there was a faience-maker named A. Clérissy at Marseilles, * and another P. Clérissy at Moustiers, whose relationship it is impossible to ascertain, and whose works bear some slight resemblance to one another.

The beginning of the manufacture of Moustiers dates, therefore, from Pierre Clérissy (1652-1728), and took place a little before that of Marseilles in the last quarter of

* See page 56 . 


\section{FRENCH POTTERY \& PORCELAIN}

the seventeenth century. One cause of the rapidity with which it reached perfection was the check placed on the manufacture of plate in 1672 by the sumptuary laws of Louis XIV.; the pieces issued from the goldsmiths' shops were burdened with a very heavy tax, and $a$ fresh ordinance of the king in 1689 compelled both nobility and bourgeoisie to take all the plate in their possession to the mint to be converted into bullion. They were oblige to replace it on their sideboards and dressers by pottery; and this was the origin of the richness of this faience and the success achieved by the finest pieces.

Pierre Clérissy found a valuable collaborator in Viry, who began to reproduce on faience the works of Tempesta, a Florentine painter of the eighteenth century, and also those of Frans Floris. To these two potters must be attributed some of the large hand-basins, standing on feet in the form of lions' paws, ornamented with scallops or arabesques, and representing mythological subjects. To them also belongs the credit of the superb dishes with hunting-scenes, like the examples in the Sèvres Museum representing a battle between Christians and Saracens, signed G. V. F. 46 


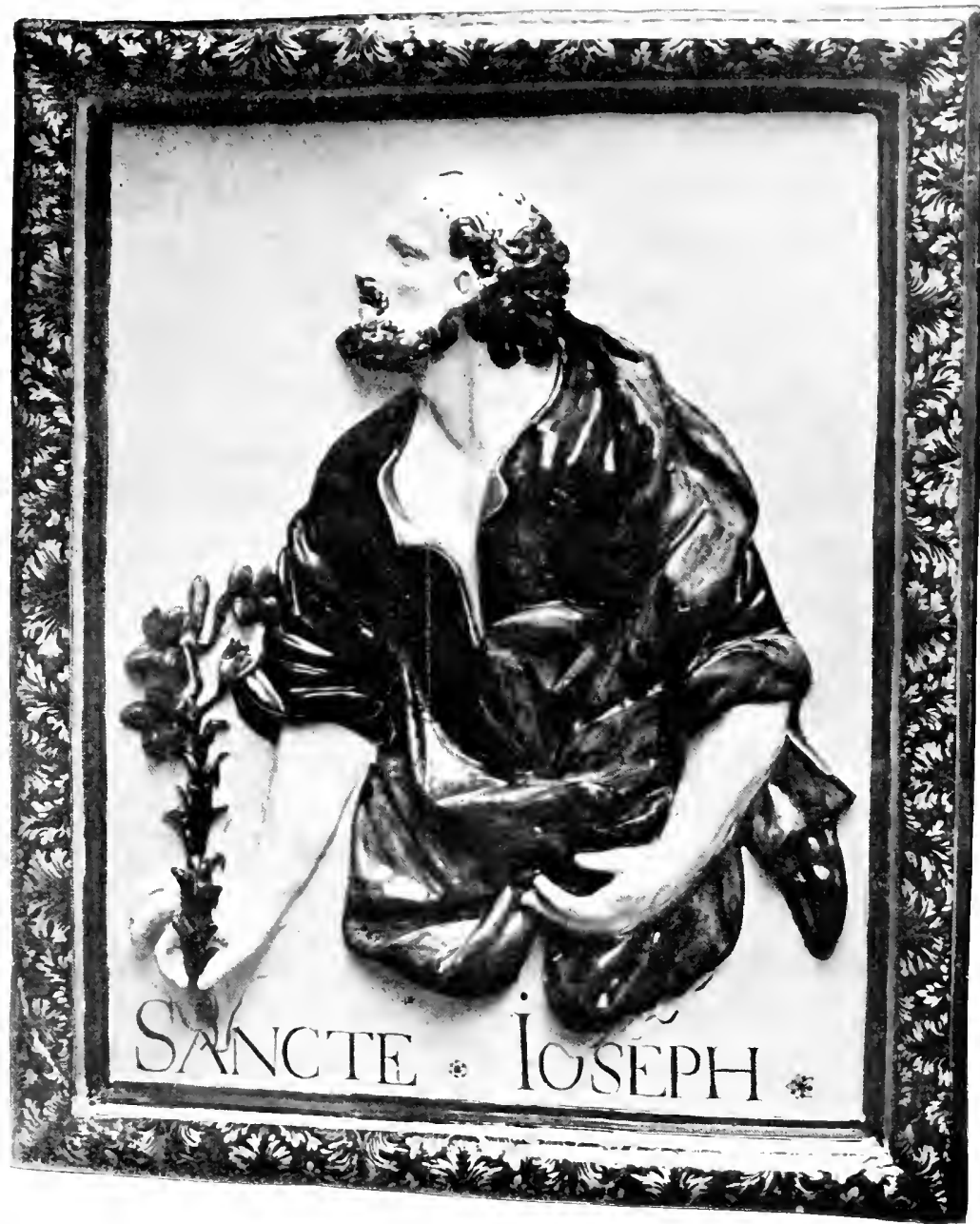

H. 31

BAS RELIEF. of Uld Moustiers Faience. Polychrome. End of XVII century. Museum of Châtean Borély, at Marséilles. 



\section{FAIENCE : MOUSTIERS}

(G. Viry fecit) and F. V. F. In the Arnavon collection there were six very fine dishes with hunting-scenes in blue camaieu. One is a very highly finished representation of bustardhunting. The other, a stag-hunt, is richly decorated with scallops and lace-work on the rim, and has a more important frame-work round the central subject. There is another of these dishes, representing "The Good Samaritan," in the Borely Museum at Marseilles with the inscription:

"G. Viry fit à Moustiers chez Clérissy, I7 II."

To the same makers we also owe six large very full-bellied urns and several which may be found in the possession of the old Marseilles families. All these pieces by the elder Clérissy are decorated in blue, often delicately shaded and generally not so dark as in the Rouen dishes. The first attempts at the use of a number of colours are extremely rare; the Borely Museum has another. To a certain extent they recall Della Robbia ware. One of these panels represents St. Joseph half-length and in profile. Under his left arm he holds his blue cloak, which lies in broad folds; his right hand is holding the lily. His tunic is 


\section{FRENCH POTTERY \& PORCELAIN}

green with a yellow lining. The picture is surrounded with a framework of green leaves, edged with white and yellow, on a blue ground. The bust of the Virgin, like the Joseph, is life-size. The beautiful tones of her orange-yellow robe, which has red lights on the folds and is edged with a red ribbon at the neck, make up a magnificent and very rich ensemble of colours; the same Virgin is also to be seen in the Musée Céramique of Rouen, where it is attributed to the manufactory of Alcora. As a matter of fact it seems to have been made before the Alcora manufactory was started.

These two makers of faience were succeeded by Pierre Clérissy II. and J. B. Viry, the son of G. Viry (who died in I 720). We have now reached the period of the Regency style, the decoration of dishes has become lighter, and hunting-scenes and battles are being replaced by graceful mythological subjects. The paintings of Moustiers were under the influence of John Berain, Picard, and B. Toro of Toulon.

About 1736 an event of some importance occurred in the history of Moustiers. The Spanish ambassador, the Count of Aranda, obtained leave from the king to take some 48 


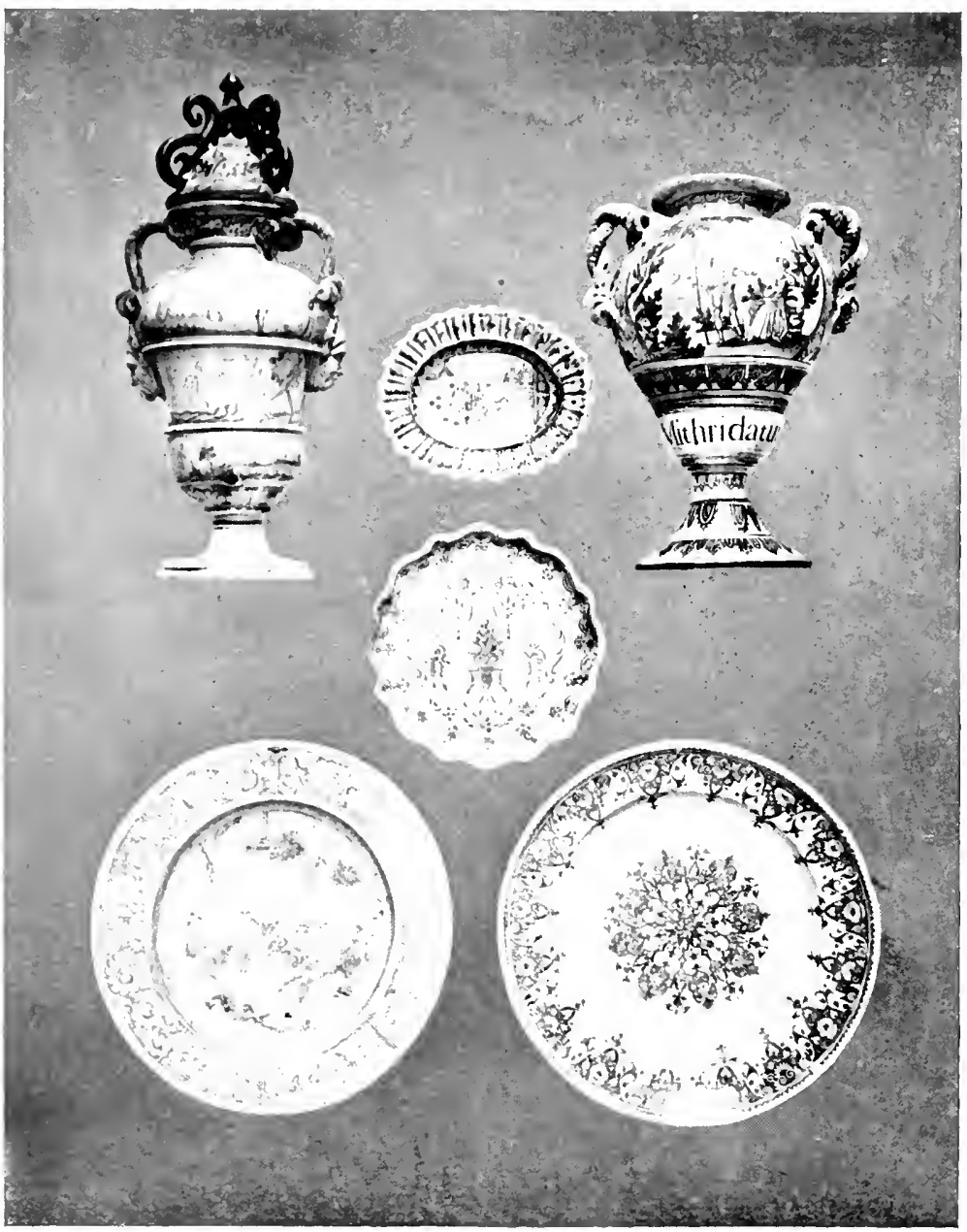

H. $2+\frac{1}{3}$

H. I 8 !"

OLD MOLSTIERS FAIEXCE. The Vase on the right is old Mar. seilles Faience of the manufactory of St. Jean du Désert. The other Vase on the left is Moustiers. 



\section{FAIENCE : MOUSTIERS}

workmen from Moustiers to his faience manufactories at Alcora, to teach his workmen the secrets of Provençal pottery. Among them was Olérys, one of Clérissy's most able assistants. Olérys brought back from Spain the secret of the polychromatic faiences (of which a fine example appears in a plate in the Girauldeau bequest in the Louvre), and joined with one Laugier in setting up a faience factory at Moustiers, which lasted with great success from 1738 to 1749 . To that factory we owe two of the most beautiful pieces of Moustiers I have ever seen: the water-jug and basin which were once in the possession of $\mathrm{M}$. Gamel, a former president of the civil tribunal of Marseilles, whose family sprang from the Basses Alpes. The decoration is polychromatic, with landscapes, figures, and flowers. The lid, which is attached to the jug by a pewter mount, shows Diana at her toilet ; the neck of the jug, which is vase-shaped, is decorated with rich garlands of flowers, and the lip with ornaments. The belly is entirely occupied by a landscape with male and female fauns playing in it. The rim of the basin is slightly curved over, and the edge is also decorated with wreaths and ornaments; the 


\section{FRENCH POTTERY \& PORCELAIN}

middle is occupied by a landscape where Leda is seen seated beneath a tree, calling to her swans. Above, Cupid is seen, aiming an arrow at her.

These pieces, like most by the same makers, and contrary to Clérissy's custom, are signed with their mark, an $\mathrm{O}$ crossed by an $\mathrm{L}$. When the eleven years of their partnership came to an end Olérys worked for a number of faience-makers, from 1749 to 1783 .

The Limoges Museum possesses a magnificentspecimen of this period: an épergne formed of nine pieces, and signed Hyaci-Rossetus, the Latinised form of Hyacinthe Roux's name.

The other manufactories of Moustiers imitated Olérys' decorations, and profited by the presence in Moustiers of the Spanish painters Solira, Salomé, Grangel, and Vélox, who had come there in the wake of Olérys, to transform their blue ornamentation into polychromatic painting. Pierre Clérissy the second was ennobled by King Louis $\mathrm{XV}$. in I 743, and given the post of secretary-councillor to the king in the Provençal Parliament. Some authorities affirm that at this time he gave up his manufactory to his partner, Joseph Fouque. But, as a matter of fact, he thought 


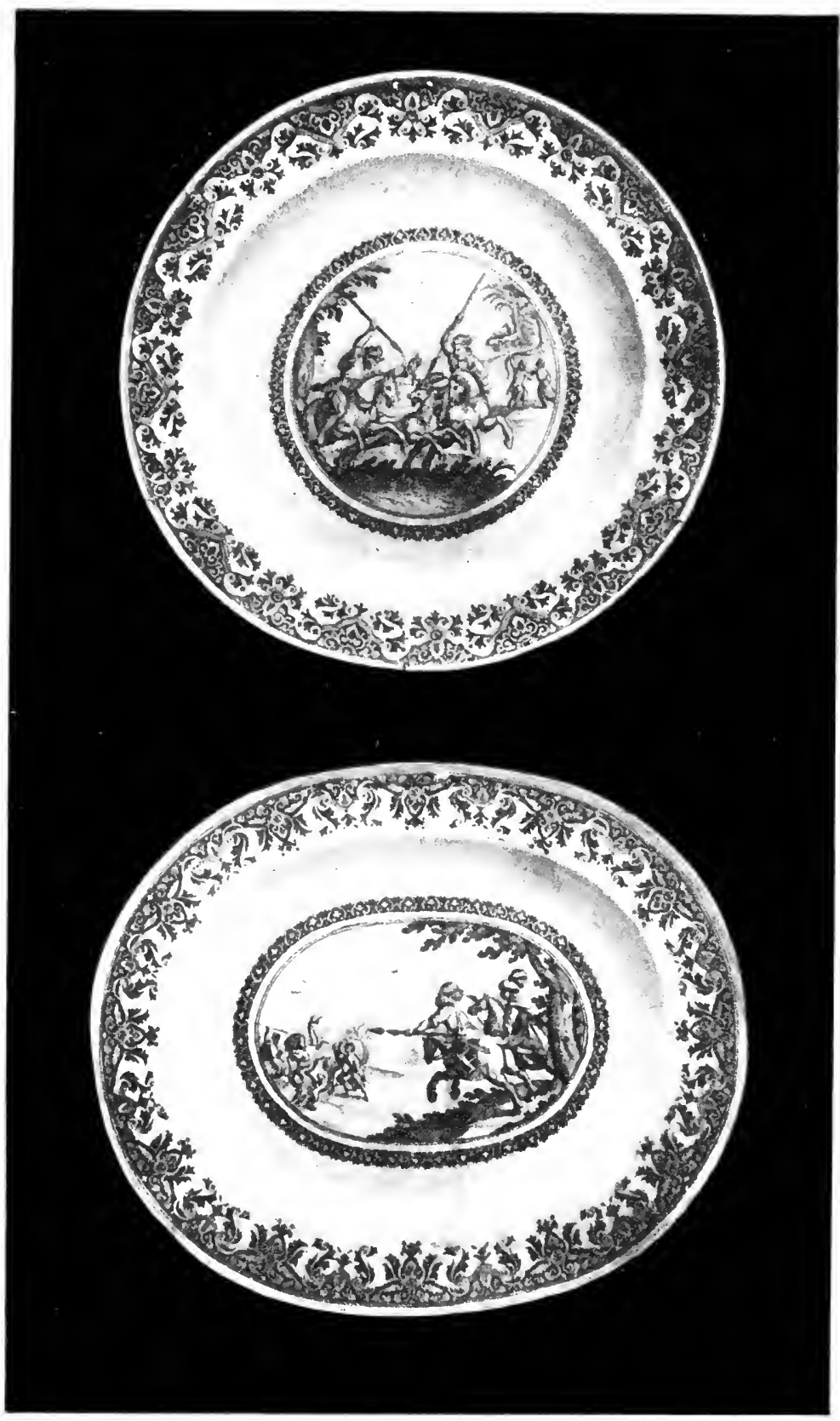

$1 \mathrm{II}, 2 \mathrm{I}$,

DISHES, Monstiers faince. Formerly in the collection of the late M. Louis Arnavon. 



\section{FAIENCE : MOUSTIERS}

so little of retiring that just then he hired a piece of land for nine years in order to obtain argillaceous earth from it.

His giving up of the factory did not come about until I747, when the office he had accepted from the king did not permit of his continuing master-faience-maker. The birthcertificate of a daughter of Fouque, wherein the latter is described as "master-faiencemaker," corroborates this statement; deeds signed by him during the previous year only bearing the qualification of "masterpainter."

Under the direction of Fouque, the manufactory maintained its high reputation; witness various pieces signed by his name. From I 756 onward the number of faience factories attained vast proportions, while the artistic value of the productions diminished. Although the enamel had lost nothing of its purity, the drawing of subjects and flowers had deteriorated, and daily became more vulgarised. Olérys, who had been the cause of the magnificent development of the Moustiers manufacture, made the mistake of permitting later that grotesque ornamentation borrowed from Callot, and thereby accelerated the de- 


\section{FRENCH POTTERY \& PORCELAIN}

cadence of the manufacture. It was as rapid as the development had been, and the Revolution gave the finishing stroke.

I had the curiosity to visit this once flourishing town; it is now no more than a hamlet in the recesses of the Basses-Alpes, surrounded by picturesque and romantic rocks, which overhang deep valleys. All that is left to recall those great faience-factories of the past which once made the prosperity and glory of the country-side, is the earth on which one treads-that earth so admirably suited to all the requirements of ceramic art. 


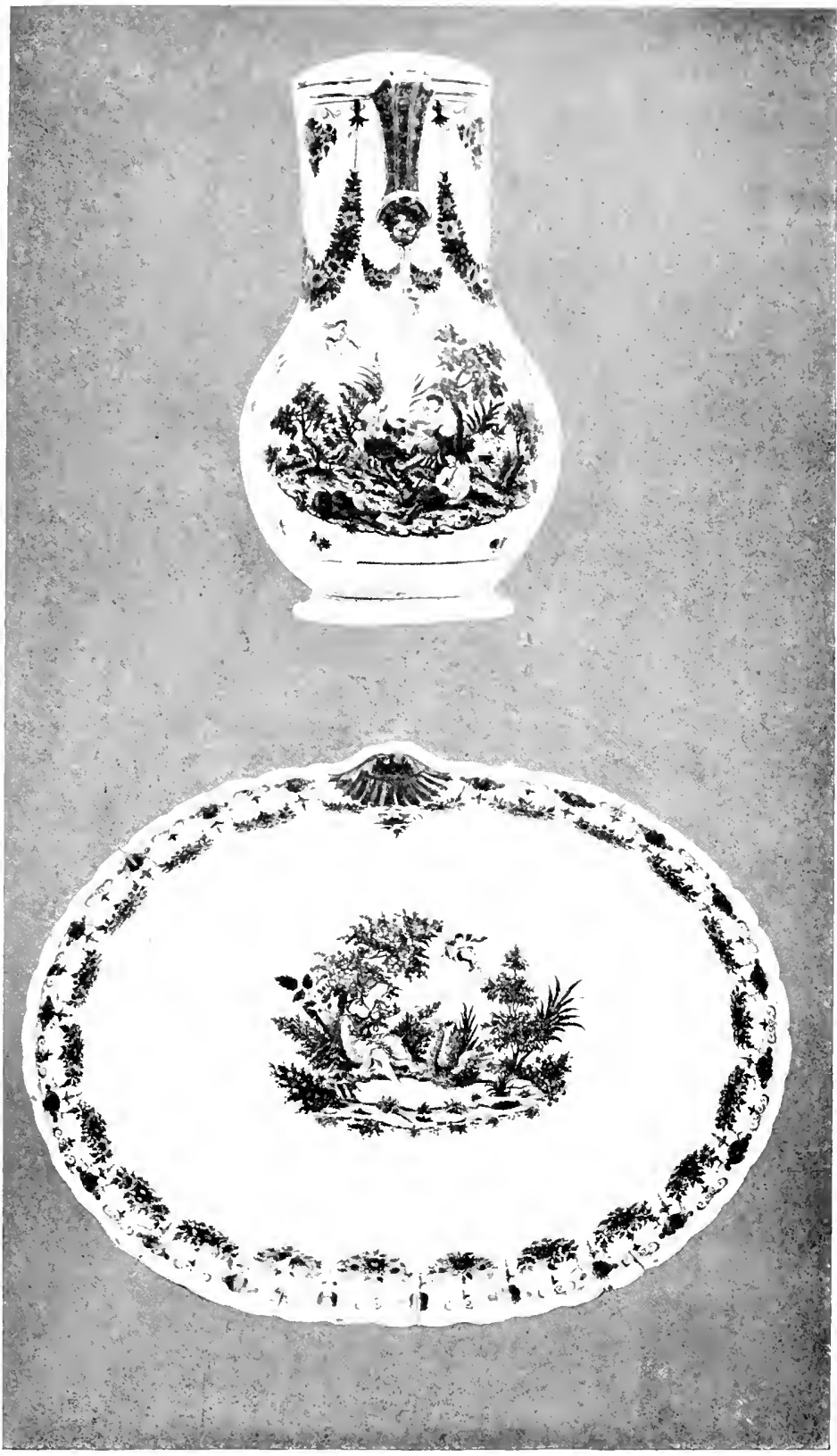

Jug, H, 12!' Dish, I, I \&!

WATER-JLG ANI) DISH, ()hl Mumstiers Wire. Called "Lat Toilette de Diane." (of the factory of Langier "and Oléry. From the Gamel Collection. 




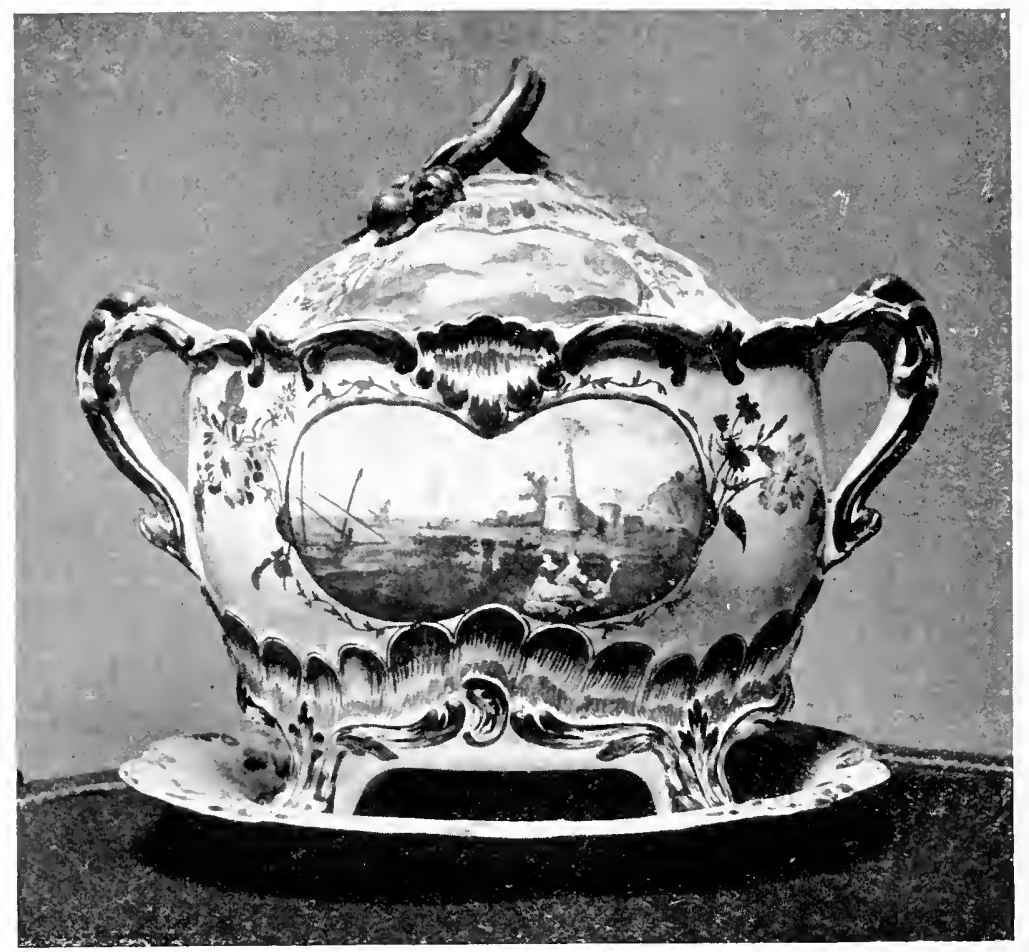

H. $10 "$

[Photo, D Freuler, Paris

OLD MARSEILLES FAIENCE. In Manganese Violet. Manufactory of Fauchier. Charles Roux Collection. 
THE SIXTH CHAPTER

\section{FAIENCE : MARSEILLES}

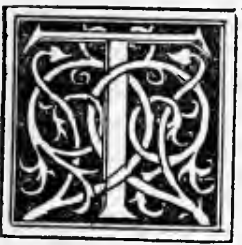

HE manufacture of ceramic in the South of France is of very ancient date, as is attested by the excavation of various fragments of pottery on the site of the old Phocian city; specimens of these are in the Sèvres Museum. It was in the fifteenth century, in the reign of King Rene (whose picturesque abode is still to be seen in the old quarter of Marseilles), that the fabrication of bricks or varnished tiles seems to have been begun, such as those that have been preserved in the Chapelle de Saint-Pierre at Auriol. If historians are to be trusted, there were formerly to be seen over the door of the ancient church of the Observatory the arms of Honore of Savoy in terra-cotta, painted according to the Italian process; but these must have disappeared when the church was. demolished in 1746. In a chapel of the ancient Église des Accoules there have been discovered the remains of a crucifix in faience, made of yellow paste so soft as to be easily 


\section{FRENCH POTTERY \& PORCELAIN}

scratched by a steel blade; white, blue, and yellow enamels are here employed. This is the first trace of faience at Marseilles.

It was in the little market town of Fayence (Var) that the first manufactory of faience was established in this part of the country. Documents are not lacking to confirm the fact. Mèzeray recounts the success obtained by Lesdiguières in Provence (1592); and describing his entry into the little town, he writes: "Fayence, more famous for the earthen vessels made there than for its size, gave little resistance." The art of making majolica, entirely lost in Italy by I 455, thus reappears in a little town of Var. Some people have therefore supposed that we owe to this fact the very name of faience. That is Montreuil's opinion, but a very disputable one. It is much more likely that the name came from Faenza, as is proved by authors of the sixteenth century calling the ware "La faenze," whilst the name of the town is simply Faventia; moreover, Moreri says in his Historical Dictionary: "Many confound this market town with Faenze, a town in Italy, on account of the ware that is there made."

54 


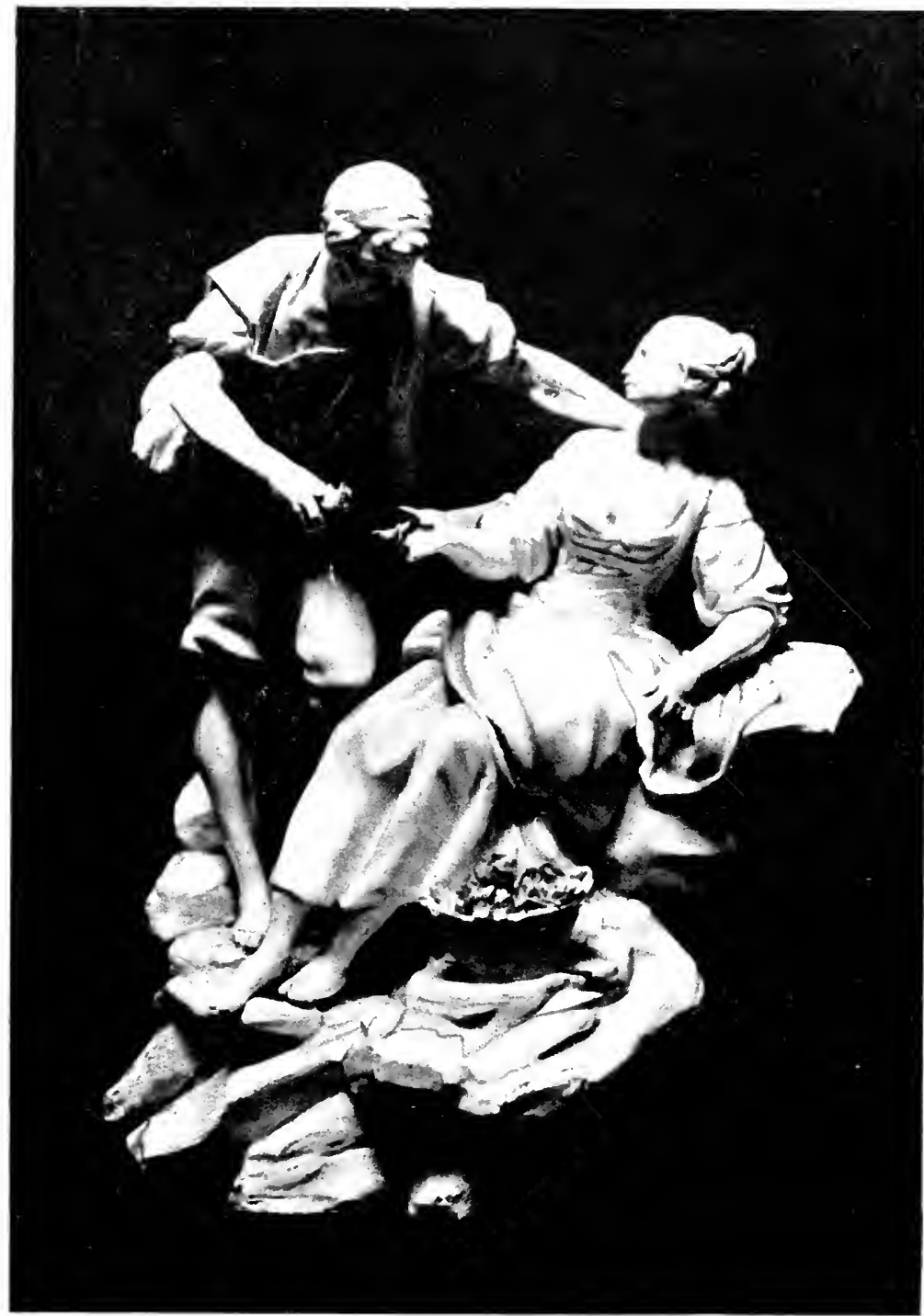

$\mathrm{H} \cdot 7$

[Phote, D. Fruter, Paris GROUP, in white Marseilles Faience. Charles Roux Collection. 



\section{FAIENCE : MARSEILLES}

This is, however, but an unprofitable discussion; what is of more importance to find out is the question how the secret of the faience was brought to Marseilles. Ordinary common-sense would suggest that workmen hailing from Var imported the secret of their process with them. The fact that there are at Sevres three dishes in old Rouen ware, bearing marks that are found on a great many pieces of old Marseilles faience, has given rise to the supposition that workmen of Fayence went first to Rouen, and that a manufacturer of that town afterwards established a factory at Marseilles. But this theory seems to me a too confident one.

My personal conviction is that Fayence was too near Marseilles for the art of making faience to have come into the Phocian town by way of Rouen, and that there was naturally intercourse between the neighbouring towns.

The first manufactory was in existence at the end of the eighteenth century at Saint Jean du Dèsert, a small suburb of Marseilles. Certain writers, notably Mortreuil, have asserted that the first production was that of Jean Delaresse (1669). I know no work by 


\title{
FRENCH POTTERY \& PORCELAIN
}

this potter; a far more celebrated name is that of Clérissy, and a small number of his pieces are in existence, signed

\author{
A. Clérissy \\ A St. Jean du Dèsert, I697 \\ À MARSEILLE
}

It is important to note (for the fact has led to much confusion), that another man named Clérissy lived at Moustiers at this same time. What family connection, if any, there was between A. Clérissy of Marseilles and this Pierre Clérissy of Moustiers, no one has been able to discover for certain. We have no proof either way. In any case Clérissy of Marseilles was not necessarily a native of Moustiers-as some have said-for the archives of Marseilles in the fifteenth century contain the name of a notary called Clerici. Possibly he was a common ancestor of the Clérissys; just as possibly they were not related at all. From the vague resemblance which exists between the pieces made by the two men no conclusion as to relationship can be drawn with any certainty; for it is not surprising to find even more definite resemblances among the productions of the same $5^{6}$ 


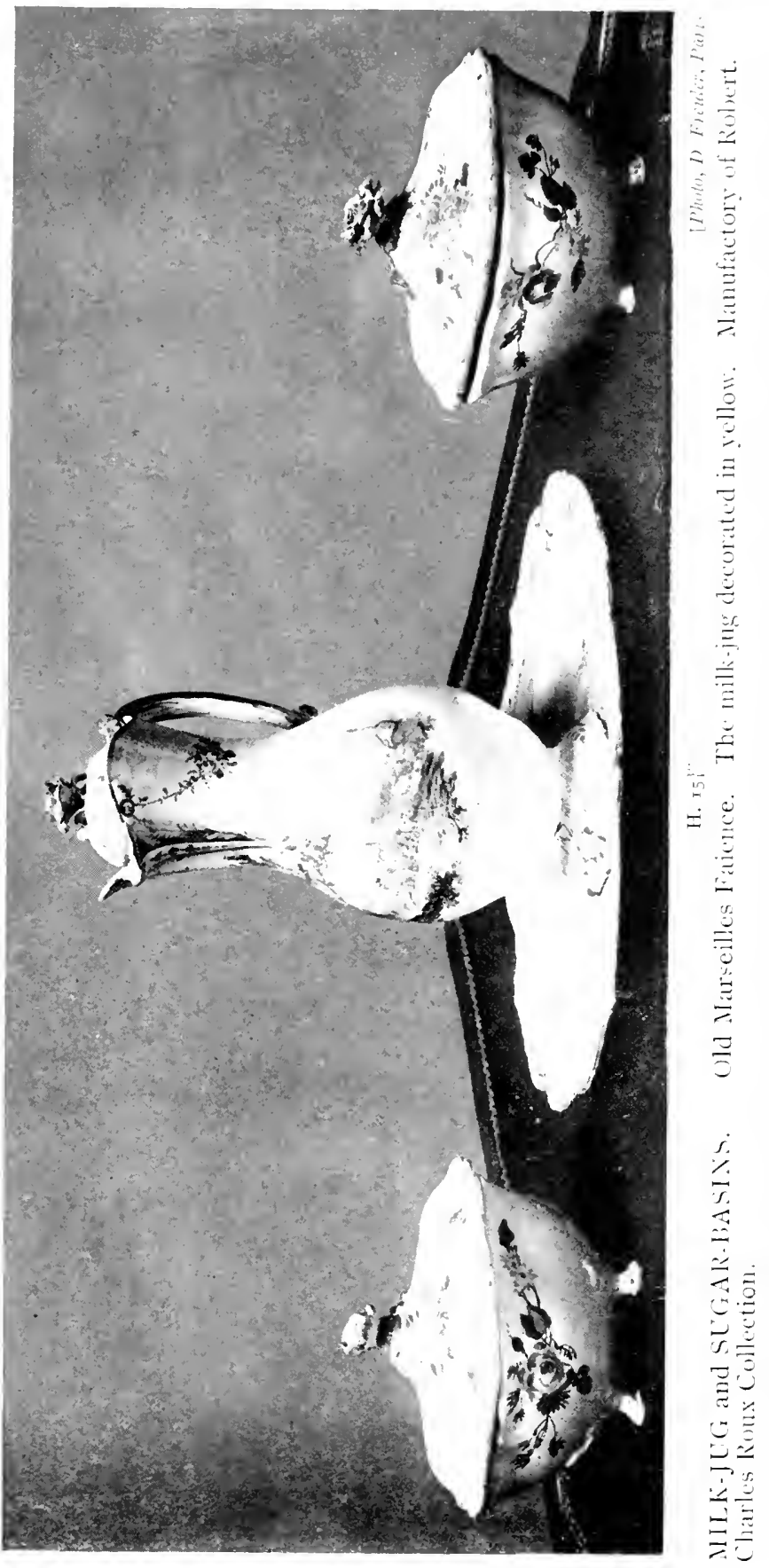





\section{FAIENCE : MARSEILLES}

date and the same province, where workmen probably moved from one town to another. One argument for the relationship is based on the fact that both at Moustiers and at Marseilles dishes were decorated with subjects taken from the work of the Italian painter Tempesta; but this is perfectly well explained by the vogue which this artist enjoyed in Northern Italy and Provence. Marseilles, however, imitated Tempesta less exclusively, preferring to choose Scriptural subjects, and even when borrowing from Tempesta reproducing his designs in quite different colours. While the subjects of the Moustiers dishes of that period are treated in blue and white only, Marseilles had already begun to display that wonderful polychrome which she afterwards brought to such perfection, and used yellow colouring or manganese violet in the decoration of her ware. The essential differences which distinguished-and were still further to distinguish-the ceramic art of the two schools, are clearly perceptible if pieces by the two Clérissys are compared: the Moustiers ware is rather more clumsy in shape, as is natural to the coarser art of a mountain population ; 


\section{FRENCH POTTERY $\mathcal{E}$ PORCELAIN}

that of Marseilles is more graceful, as one would expect from a Greek race strongly tinged with Latin blood.

Next to that of Clérissy, Faulchier's manufactory is the oldest. In the collection of M. Th. Mante at Marseilles there is a statue of the Virgin which is a well-nigh perfect work; and we also know of three beautiful souptureens in the collection of M. Charles Roux, which are decorated in manganese violet. The latter pieces are not signed; but that belonging to $M$. Mante bears the superscription :

J. Faulchier, I735

In a short time-towards the middle of the eighteenth century, that is-Marseilles possessed no fewer than twelve potteries, ten of which manufactured faience. They were as follows: Agnel and Sauze, near the Porte de Rome; Antoine Bonnefoi, near the Porte d'Aubagne; Boyer, at La Joliette; Fauchier, near the Porte d'Aix; Veuve Fesquiet, outside the Port Paradis; Veuve Perrin and Abellard; J. G. Robert ; Honoré Savy, all three outside the Porte de Rome; and J. B. Viry, outside the Porte de Noailles. 58 


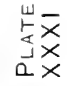

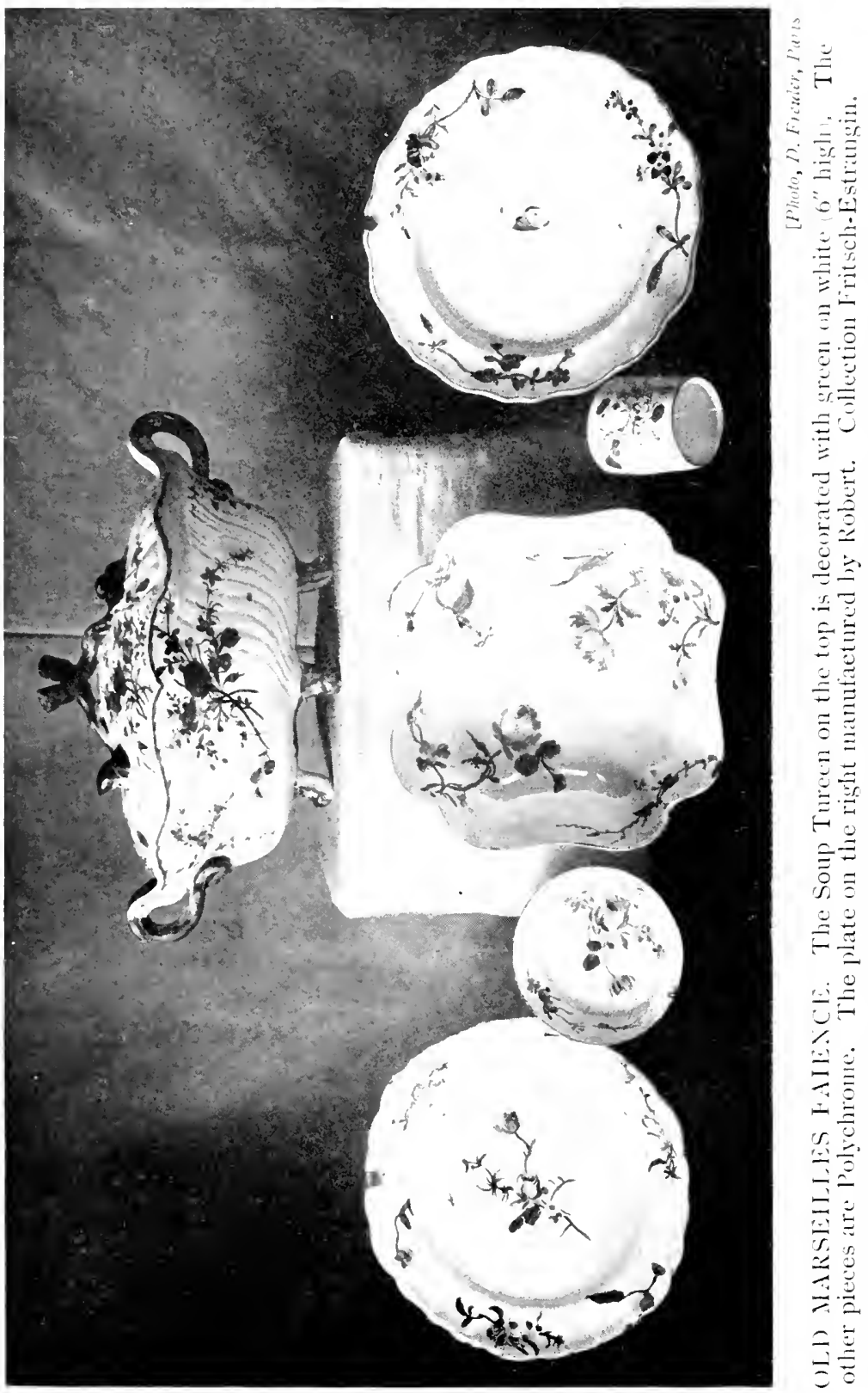





\section{FAIENCE : MARSEILLES}

Besides these there was Jacque Borelli, a potter from Savona settled at Marseilles. The latter's productions are signed with his name; those of Bonnefoi bear the letter B as their special mark, traced with the brush in yellow ochre; those of the others are either only distinguished by their respective initials, or are not signed at all. But what chiefly characterises the dishes and plates of this manufacture, and is equivalent to the most authentic signature, is the brilliant whiteness of the thick white enamel that forms the ground for a decoration consisting of flowers or imaginary landscapes according to the artist's fancy. The designs occasionally leave something to be desired: the composition of the landscapes is as careless as that of the inferior pupils of Karel du Jardin ; but the beauty of the material makes up for all defects, although it must be owned that Bonnefoi appears to have been chiefly anxious to produce cheap articles. His favourite colours are yellow ochre, purple, and green compounded of a mixture of yellow and blue.

Honoré Savy, in I749, re-established Clérissy's workshop, which had stopped 


\section{FRENCH POTTERY \& PORCELAIN}

producing about forty years before.* On December I7, I765, Savy, encouraged by previous success, applied for a licence to set up as a manufacturer of faience and porcelain ; the favour was refused, but official encouragement was not wanting. On the occasion of a visit to Marseilles by the Comte de Provence, brother of the reigning monarch, and afterwards himself king under the title of Louis XVIII., the Journal des Fetes speaks of a visit paid by the prince to Savy's workshop:

"Monsieur went to the Sieur Savy's manufactory of faience as he had announced on the previous day. The municipal guard lined the route. This manufacturer had during the night had his workshops put in order to receive the visit. All the workmen were posted in their various rooms, and matters were so disposed that the Sieur Savy had the satisfaction of showing the prince all the processes of his manufacture from the commencement to the completion of a piece. Monsieur was afterwards intro-

* This is the opinion of Maze-Sencier, but some writers contend that Clérissy's factory did not cease work till a later date.

60 


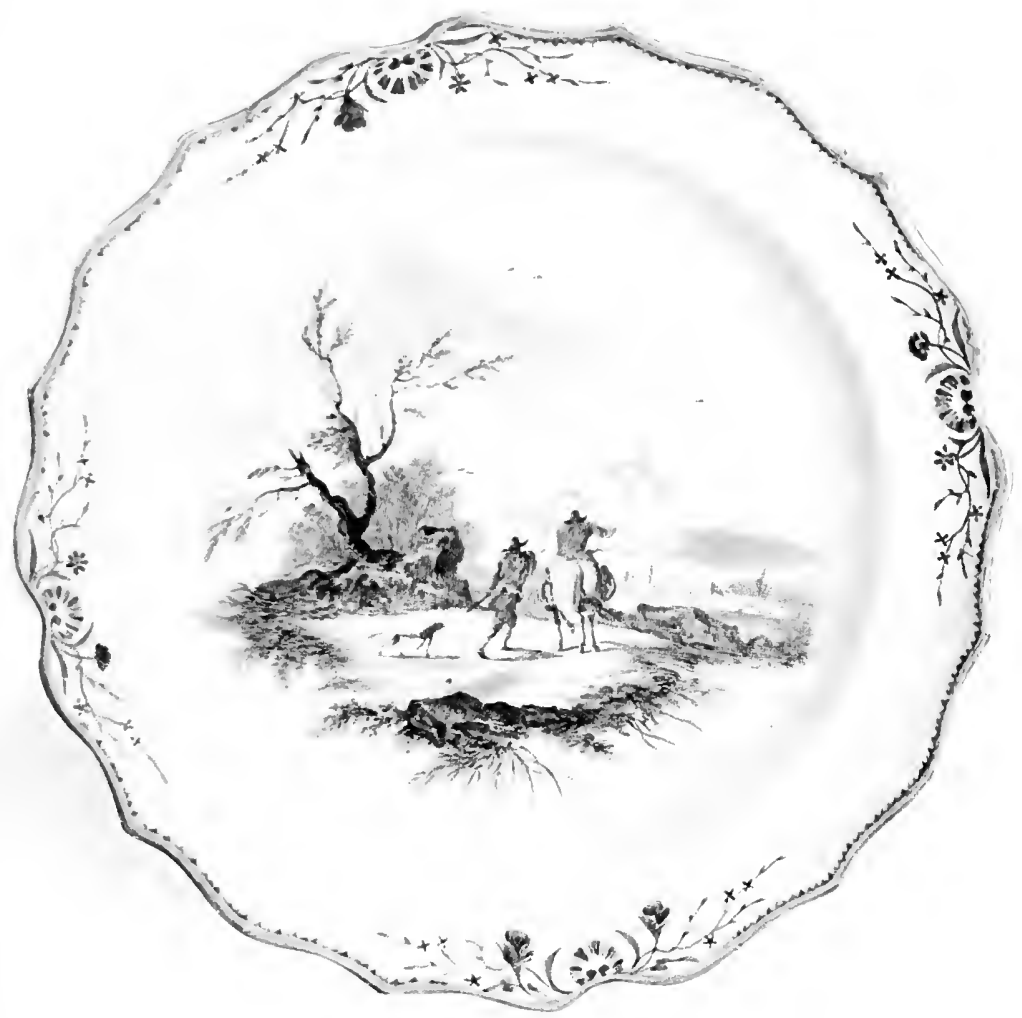

PLATF, OLD MARSEILLES FAIENC'H (Mamutactory of the Wham Perrin) south Kensington Wusem Diameter 11 inches 

FAIENCE : MARSEILLES

duced into the large gallery of the factory, where he saw a quantity of work of every kind, whose perfection he was gracious enough to approve. The prince seemed so well satisfied that he permitted the Sieur Savy to place the manufacture under his protection, to put his arms thereupon, and to erect in the middle of the gallery the statue of the prince which he proposes to make."

It was in consequence of this visit that Savy adopted the fleur-de-lis as a signature for some of his pieces, but the mark is by no means general on all his work. There are many pieces not signed at all which are to be assigned with certainty to Savy. His work is as a whole more careful than that of Bonnefoi. Faience most successfully decorated by him with fruit, fish, or flowers in relief, may be instanced; we must also note the beautiful quality of the plain green enamel which Savy boasted of alone knowing how to employ.

The name of Joseph Gaspard Robert marks the most glorious page in the history of Marseilles ceramic; for there is no exaggeration in comparing some of this artist's best pieces to the products of Sèvres or Saxony. 


\section{FRENCH POTTERY \& PORCELAIN}

What date should be assigned to the foundation of Robert's factory? M. Jacquemard and M. Le Blant think that it should be May I766; the establishment was at any rate in existence at the time of the Comte de Provence's visit, and had already acquired a high reputation, for the journal already quoted thus describes the visit of Monsieur to Robert's manufactory:

"Some one had told the prince of the Sieur J. G. Robert's manufactory of porcelain ; the prince appeared curious to see it; it Ivas within reach, and he proceeded thither with all his suite. This clever artist had not been forewarned, but his zeal and activity supplied all that was needful. The prince first saw in one room a large porcelain vase, whoses hape, design, and modelling riveted his attention. 'This is worth looking at,' said the prince to the gentlemen of his suite. They then examined various pieces that were together with this vase, and all gained for the Sieur Robert the most flattering eulogies.

"Monsieur proceeded to the porcelainwarehouse, and stopped before a complete service which seemed to deserve notice. $\mathrm{He}$ learned with pleasure that this service was 62 


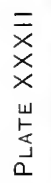

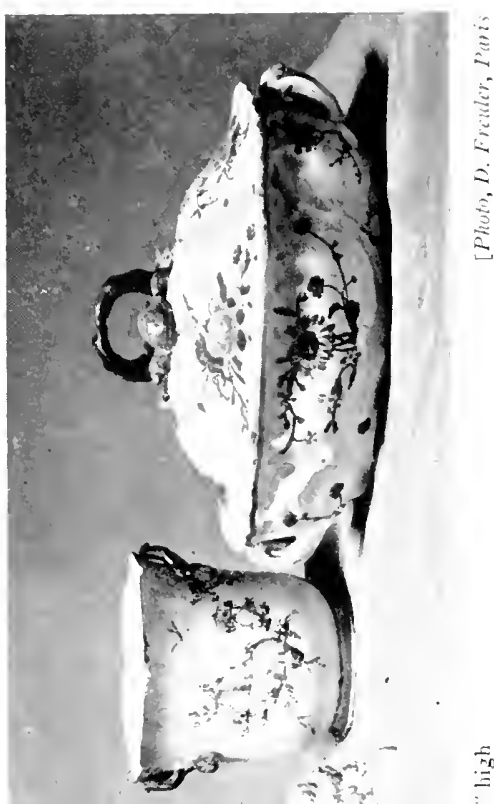

$$
\stackrel{0}{=}
$$
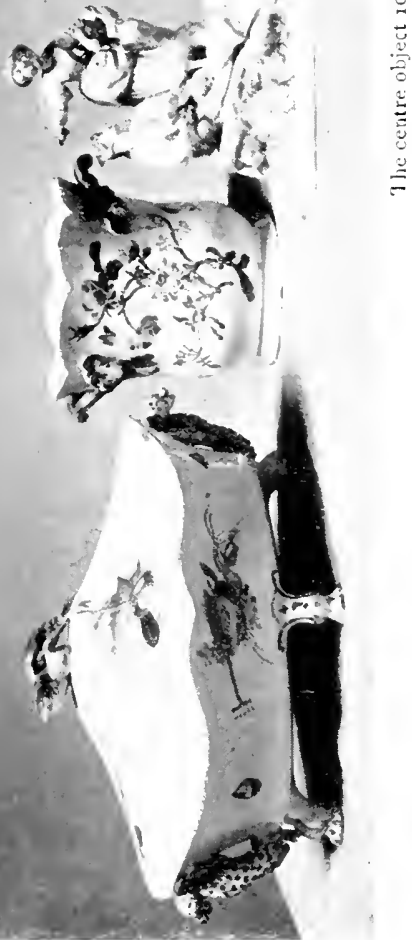

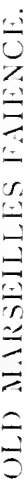





\section{FAIENCE : MARSEILLES}

destined for England. Several gentlemen of his suite were kind enough to draw his attention to the execution of various porcelain flowers, the foliage of which was as delicate as that of natural flowers.

"The Sieur Robert seized this opportunity of explaining to the prince that his manufacture was hampered by the difficulty of finding in the province material necessary for this sort of work, and he added that the thing would not be impossible if the government would assist him in the expenses of research. He flattered himself that these words would not be listened to in vain by a prince who was looked upon as a lover and patron of the fine arts.

"The prince, after having been through the workshops, deigned to encourage the workmen by renewed largesse."

Certain of these works produced by Robert are amongst the real masterpieces of eighteenth-century ceramic art, as may be judged from our illustrations.

Robert always signed his pieces, sometimes with the letters J. R., sometimes with a single R., sometimes with a sort of $\mathrm{X}$. M. Davillier possesses a cup bearing the 


\section{FRENCH POTTERY \& PORCELAIN}

monogram $\mathrm{R}$, in which some people have, quite mistakenly, thought they recognised the mark of Ferdinand IV. and the royal factory at Naples; but the latter always signed with a crown. Sèvres also possesses a beautiful round dish of Robert's, signed Robert à Marseille.* He also executed several complete services, some representing fishes only, others insects; isolated pieces from these are to be seen in different collections. One of them is here represented, and is decorated with a butterfly in the middle.

Robert's faiences generally represent views of Provence. Amidst these southern landscapes with the sea for horizon (a country that equals Greece for beauty), we see-also a vision of antique grace-peasants dancing the farandole or the mouresque, a reminiscence of the sacred dances of Eleusis. The flute and tambourines, like the fifes and drums in the worship of Cybele, sound their clear notes amid clumps of orange-trees, lemon-trees, and

* Robert also executed some pieces in porcelain, and their mark must not be confused with the R. of Gotha or of Rauenstein, the two German factories which signed in the same manner.

64 


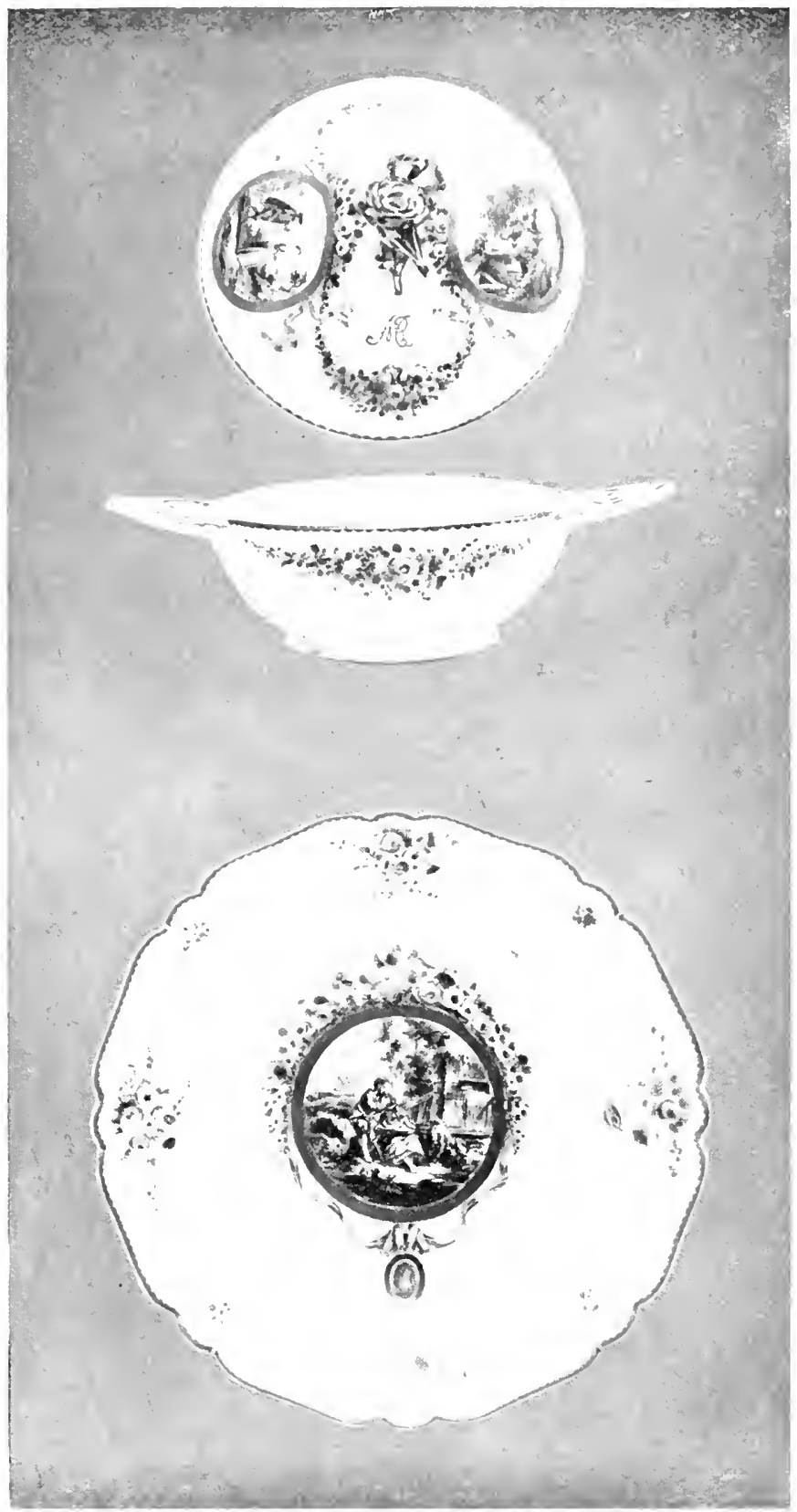

D. f plate

OLD MARSEILIES WARE, made ly Robert for the wedding of his danghter, the mastrepiece of Marseilles Pottery. Formerly in the Arnavon Collection. 




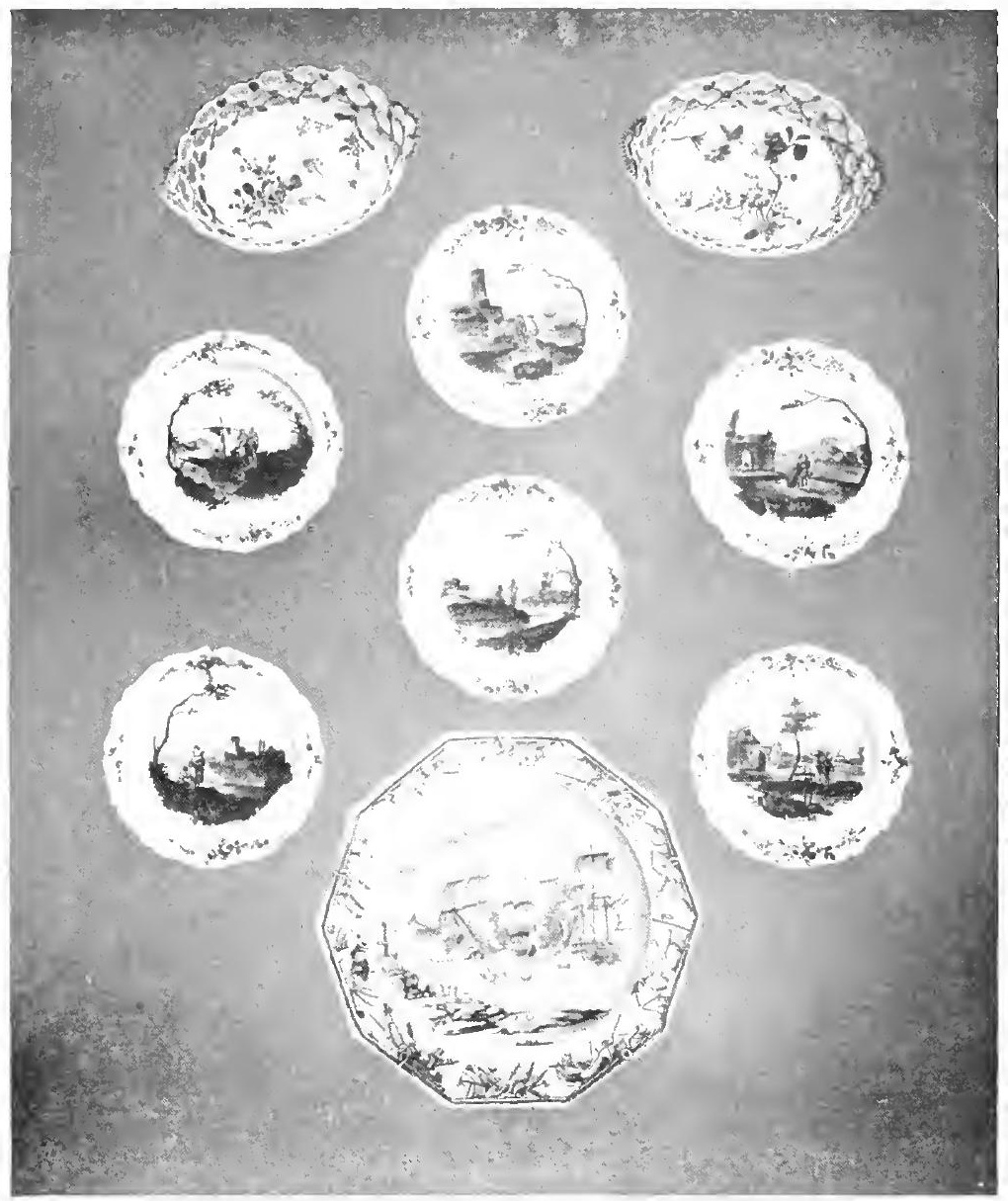

T) of large di-h, I 5 !

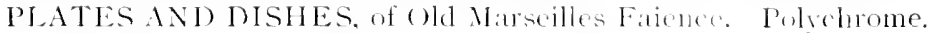
The dish below is Moustiers Fatence. 


\section{FAIENCE : MARSEILLES}

myrtles; all is gaiety and expansive joy; couples advance towards the soft shade of the great trees; shepherdesses-Phyllises or Clorindas-be-ribboned and dressed out in their best, chat with some Clitander as they tend their flocks amid climbing vines or sparkling fountains; at other times it is the harmonious silhouette of the great pine-trees, or the beauty of some Roman ruin, which touches the landscape with the melancholy of perishable things, and lends it an unexpected decorative charm. More frequently the ceramic artist gives us the seascapes which Joseph Vernet painted. There, in the golden light of some fine evening, a vessel issues forth with all sails spread from between the ancient moles that mark the entrance of Marseilles harbour; or the fishermen's barks are grouped at eventide upon a pale-tinted sea. All this is made truly lifelike by the colour and the drawing of Robert's work.

The faience made by the widow Perrin is perhaps that now most frequently met with at sales and in the hands of dealers. It is to be recognised by the mark $\mathrm{V}$ generally found on the reverse of her pieces, in black, pink, violet, or brown. They are also often signed 


\section{FRENCH POTTERY \& PORCELAIN}

with several short parallel strokes of the brush, sometimes thin, sometimes thick; but this mark is not peculiar to Veuve Perrin, and is often used by other Marseilles makers.

I should not omit to mention Fauchier together with Savy, Perrin, and Robert; the latter being the three most accomplished artists in ceramic who figure in the history of Marseilles porcelain and faience. There are scarcely any documents relating to Fauchier ; but several remarkable pieces made by him are in Charles Roux's collection. One of them, here reproduced, is a large soup-tureen of the Louis XV. shape, decorated with landscape-medallions representing the entrance of a harbour with ships.

With regard to J. B. Viry, probably he was a native of Moustiers; in fact, in the archives of that town, under the date February 2, I 706, there is mentioned a J. B. Viry, painter of faience, whose name appears again in 1726 . One may suppose that his son, who bore the same Christian name and surname, came and settled at Marseilles. He was without doubt related to G. Viry, another maker of faience at Moustiers, whose signature is affixed to a fine dish in Tempesta's manner. 66 


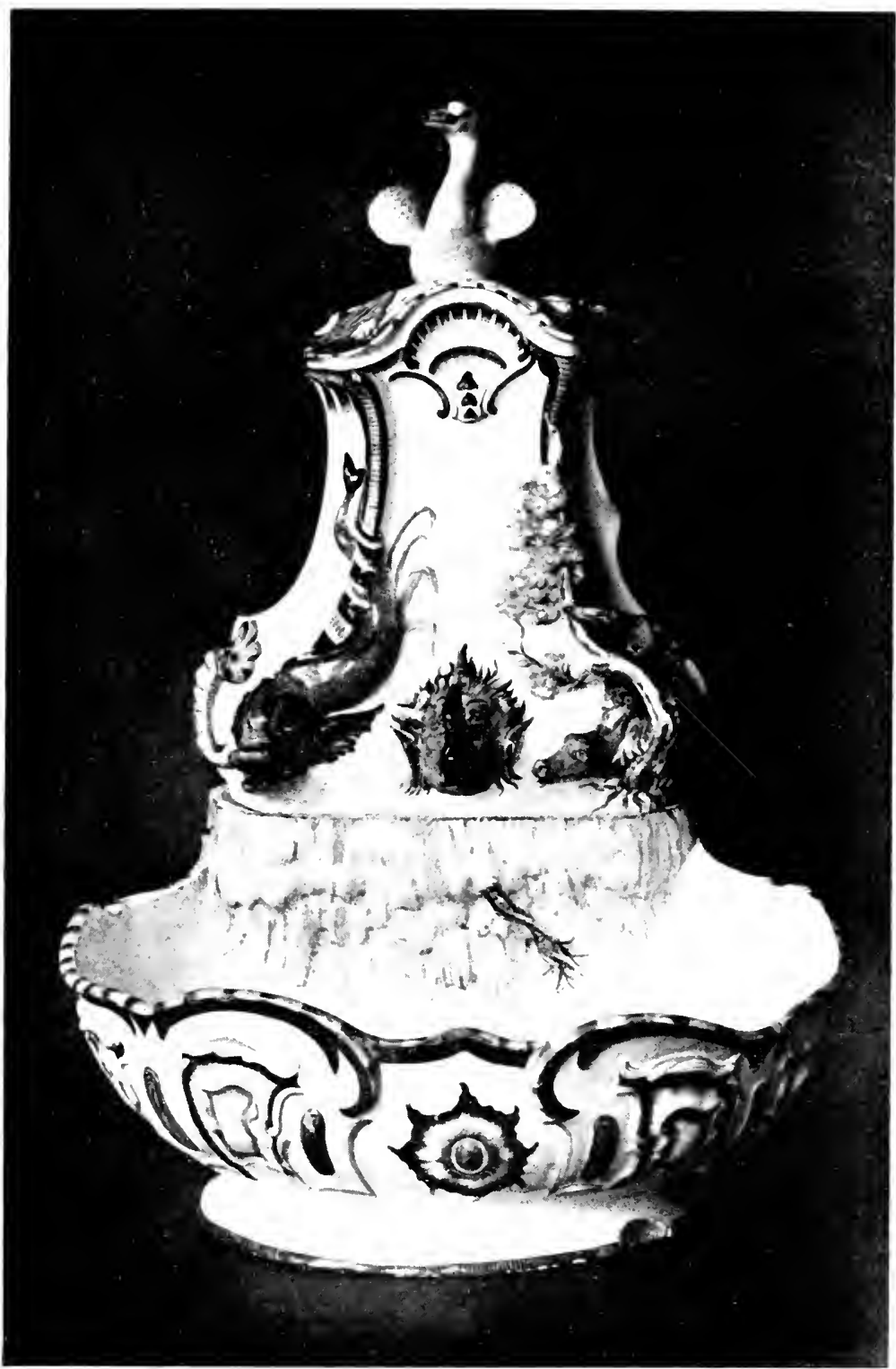

H. 221 W, $1=1$

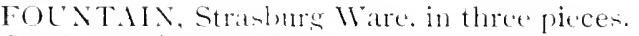

suth Kensington Musenum. 



\section{FAIENCE : MARSEILLES}

Such, briefly set down, are the personalities and achievements of those masters who throughout an entire century endowed Marseilles with a flourishing industrial art, and produced so much admirable and charming work. A document quoted by M. Jacquemart gives us, apart from all mere suppositions and conjectures, a practical and precise notion of the development of Marseilles ceramic work in the eighteenth century; it tells us that in I 766 the factories of Marseilles exported I05,000 pounds of faience to the French islands of America. Despite the near neighbourhood of Sèvres and of Rouen, Paris also had a demand for the produce of Marseilles; a decree of i 760 even authorised the Sieur Celly to sell a quantity of faience in the capital, notwithstanding the opposition of the community of Parisian manufacturers, who looked askance on this formidable competition. 
THE SEVENTH CHAPTER

\section{STRASBURG AND THE MANUFAC- TORIES OF ALSACE-LORRAINE}

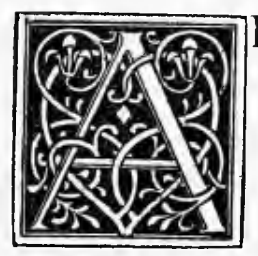

LSACE is, par excellence, the country of ceramic art ; nowhere else are there so many potteries as in this province, and this has been so ever since the Romans first colonised the land. At the beginning of the eighteenth century, however, Alsace, though manufacturing china of all kinds in fairly large quantities, was not in advance of other French centres, some of which, like Nevers, Rouen, and Moustiers, were at that time producing work of the very finest quality. One is the more surprised at this because Alsace is so close to Germany, where from the beginning of the eighteenth century faience, and porcelain especially, had attained an extraordinary degree of perfection. It must be observed that workmen had not the same facility there for passing from one manufactory to another that they had in France, where we frequently find them moving from Moustiers to Nevers, from Nevers to Rouen, 68 


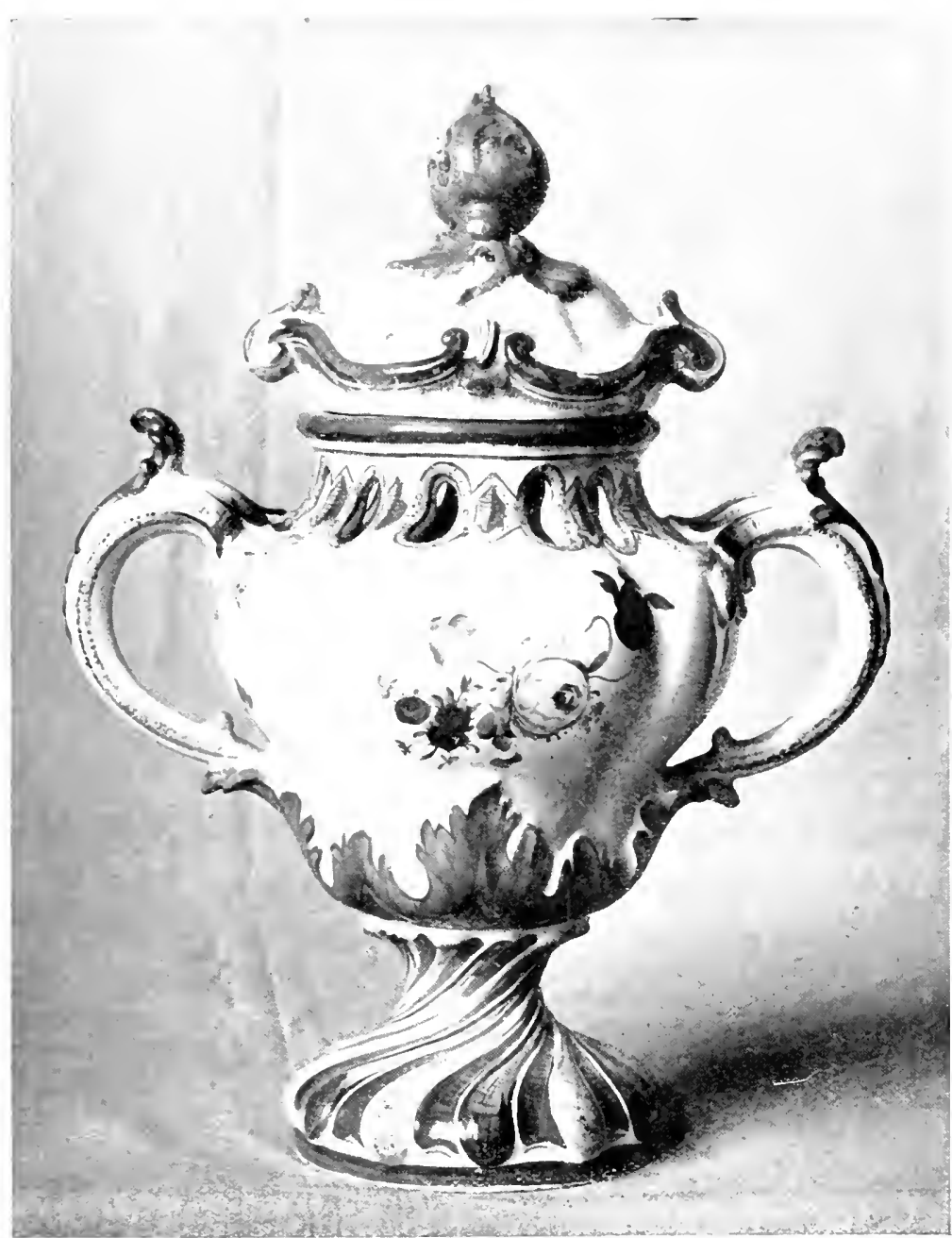

H. 9

[Photo, D. Freuler, Puris

VASE, Strasboura. About I,jo. Sèrres Musemm. 



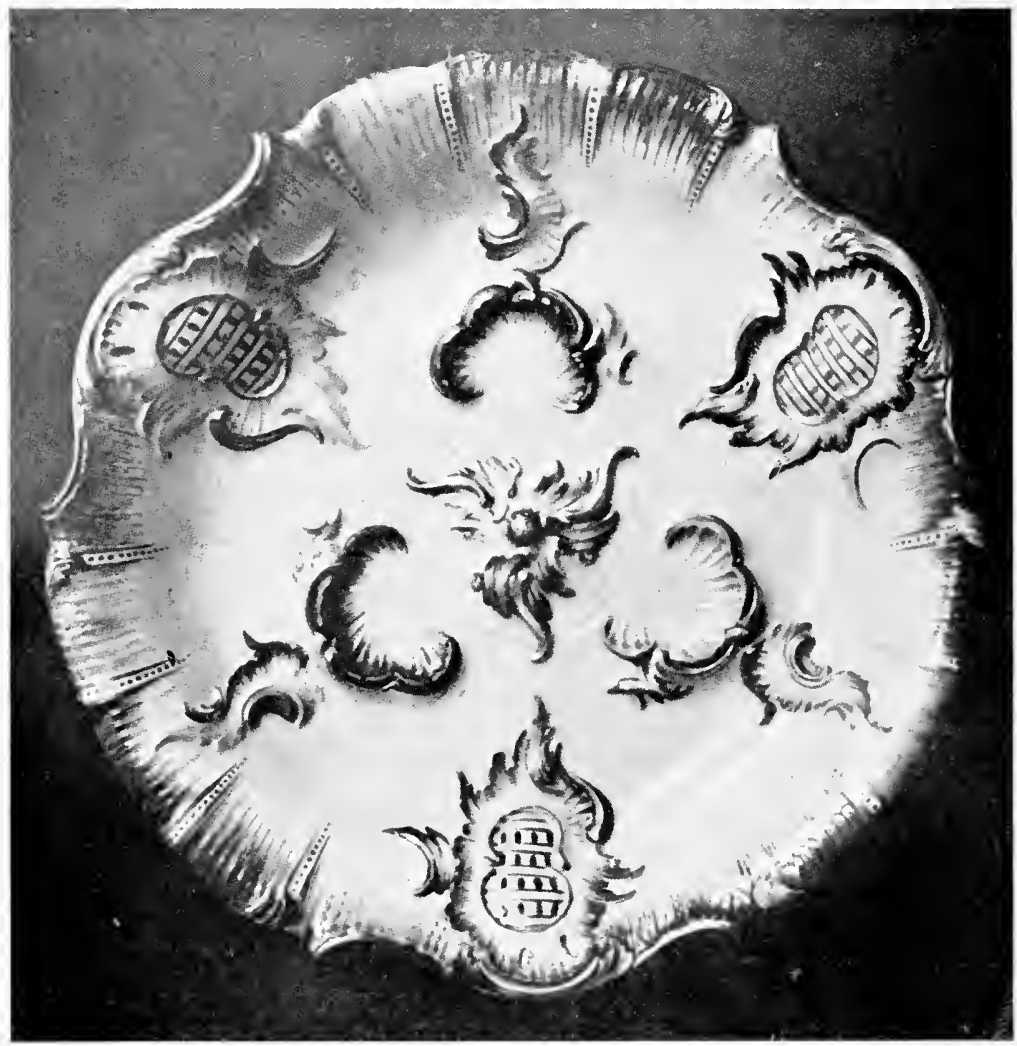

I). $8 !^{\prime \prime}$

I'LATE, Strasbourg Porcelain. South Kensington Museum. 


\section{STRASBURG \& ALSACE-LORRAINE}

from La Rochelle to Bordeaux, from Marseilles to Lunéville.*

In Saxony, on the contrary, the factory at Meissen was like a fortress, whose secrets were kept to the death, and where every traitor was punished with life-long imprisonment.

Nevertheless it was a fugitive from this town, Wackenfeld, who first attempted, but without great success, to establish a porcelain factory at Strasburg. Charles Hannong, the greatest name in the annals of Strasburg workmanship, who plays a part analogous to that of Clérissy at Moustiers, Robert at Marseilles, Levavasseur at Rouen, and Hustin at Bordeaux, founded a faience manufactory in 1709; he was a native of Maestricht, had lived at Mayence, and had acquired his ceramic knowledge at Höchst, where his sons in their turn came to study. About I 72I Hannong went into partnership with Wackenfeld in order to manufacture porcelain. $\dagger$ Hannong likewise set up a factory at Haguenau, and in 1725 he was at the head of both establishments, which he soon made

* Lunéville made perfect imitations of the work of Veuve Perrin at Marseilles, signed Lunéville.

$\dagger$ See Chapter XI. 
FRENCH POTTERY \& PORCELAIN

over to his two sons, Paul Antoine and Balthasar. The partnership between the two brothers did not last many years; in I737 they separated, each taking a factory, but later Paul bought back that of Haguenau from his brother. Under Paul's clever management the manufacture prospered, and the faience that came from his furnaces comprises some of the finest specimens of the industry. At the same time the manufacturing of porcelain was also carried on there, with the assistance of Ringler-who had managed to escape from Meissen, had founded a factory at Vienne, and had afterwards gone to Höchst-and of Löwenfinck, who also came from this last town (I750).

It was shortly after this date that the difficulties with the manufactory at Sevres began (see Chapter XI.), which ended after many vicissitudes in the departure of Hannong for Germany, where he founded the celebrated factory of Frankenthal.

His sons Joseph Adam and Pierre Antoine continued the trade. Unfortunately, in I744 Alsace faience was subjected to such a high import duty that the industry was soon in some danger of collapse. As a finishing70 


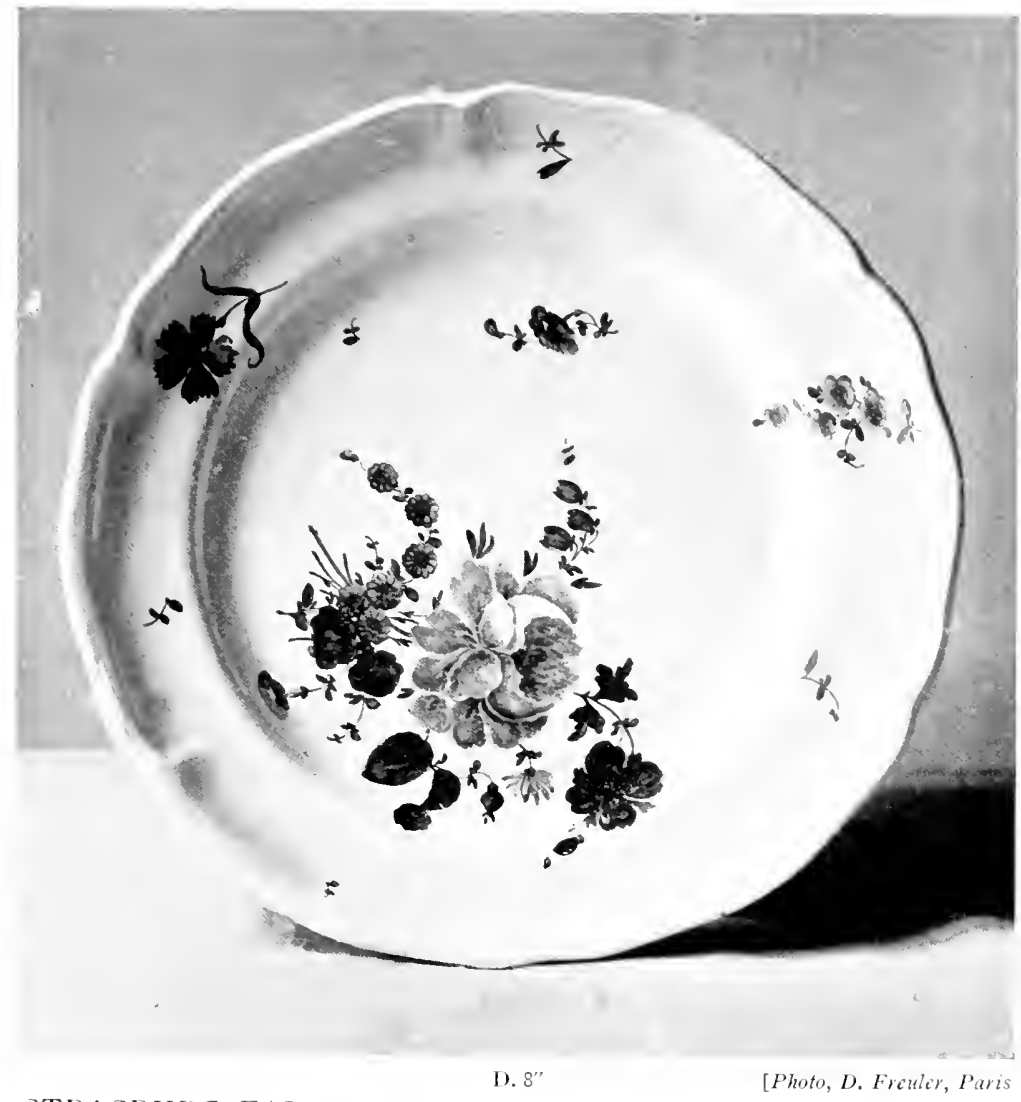

STRASBURG FAIENCE (Manufactory of Hannong), Polychrome. 



\section{STRASBURG \& ALSACE-LORRAINE}

stroke, Hannong, who had received large sums on loan from Cardinal de Rohan, found himself suddenly imprisoned at the death of this prelate, because he could not immediately discharge his debt. Despite the protestations of the unhappy man, who in vain addressed himself to the king and the royal family, his factories were sold, and that of Strasburg ceased to exist in 1780 .

We may divide the products of Strasburg into three periods. The first comprises the works of Charles Hannong and of Wackenfeld (I710-I739); the second those of Paul Hannong up to his departure for Frankenthal (1739-1754); the third deals with the management of Joseph Hannong (I760I780). The second period was the most prosperous; I may instance certain clocks en rocaille, the edges relieved with violet, decorated with bouquets of flowers in many colours, with little figures above ; the famous sauce-boat of the Sèvres Museum; and some dishes in faience representing Savoyard scenes after Pierre. During the third period Strasburg looked chiefly to prolific production; nevertheless the perfection of the work there accomplished remained constant, 


\section{FRENCH POTTERY \& PORCELAIN}

the forms of dishes and plates were gracefully rounded, the flowers artfully disposed either in the middle or on the border of the pieces, and standing out with their fresh strong colour upon the immaculate whiteness of the enamel. With this rich colouring Strasburg excelled in reproducing roses, peonies, hyacinths, and forget-me-nots. Many of the pieces were also ornamented with Chinese figures, and Garnier thinks that this decoration was imitated by Marseilles; but it is far more likely to have been the contrary way, for Marseilles, being a great port, probably received porcelain from China before Strasburg did. On the other hand Sinceny certainly copied Chinese ornamentation from Strasburg.

\section{NIEDERWILLER.}

Although Niederwiller is not in Alsace but in Lorraine, it has none the less come under the influence of Strasburg-as did also Lunéville, Bellevue, and St. Clément-a natural result when one considers the importance of the Hannongs' manufactories, which often employed as many as seventyfive workmen at a time. Niederwiller was founded at a later date than Strasburg, and 72 


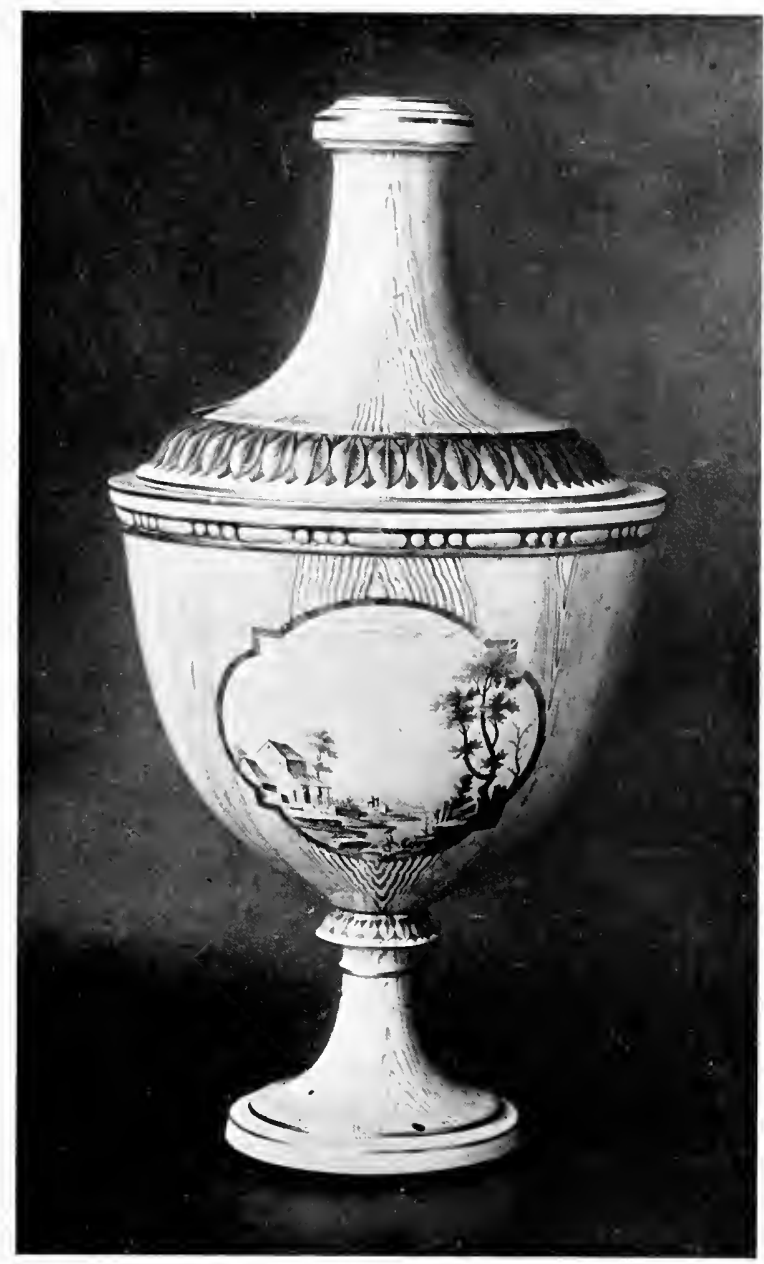

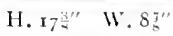

NIEDERWILLER VASE. South Kensington Museum. 



\section{.}


Plate XL

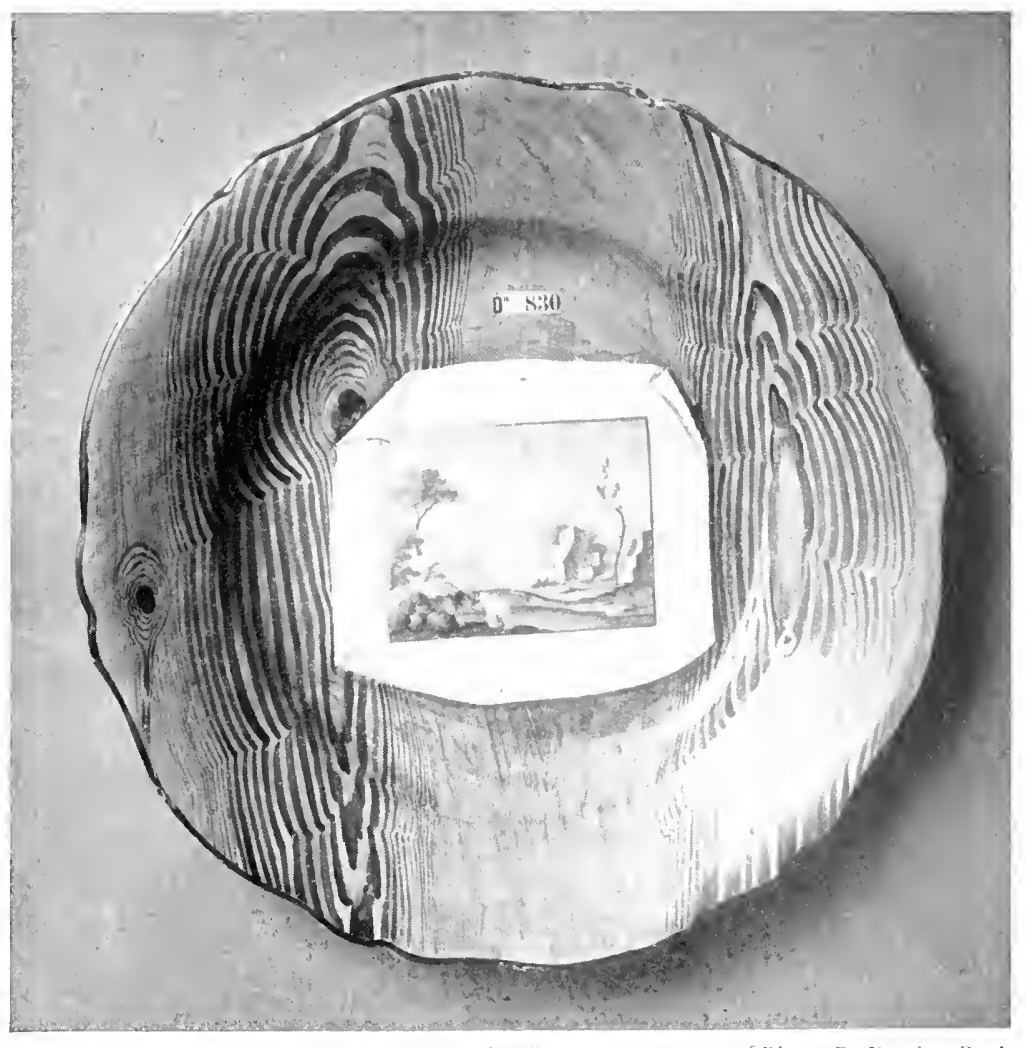

I). $8^{\prime \prime}$

[Photo, D. Freuler, Paris

NIEDERWILLER FAIENCE. Sères Musem. 


\section{STRASBURG \& ALSACE-LORRAINE}

when Baron Jean Louis de Beyerlé, councillor of the king, opened a faience manufactory in the little town in I704 Strasburg was already famous. That did not prevent her younger rival from also being prosperous. Baron de Beyerlés management of its financial affairs was supplemented by his wife's artistic management; she was a true artist, and often decorated pieces herself. Many workmen came from Strasburg to Niederwiller, where the manager earned 500 livres, while the painters, modellers and moulders received IO to 20 sols a day; and as at Strasburg, there were at Niederwiller many good workmen who had come from Saxony.

"The manufactory at Niederwiller," writes the "Almanach de Gotha," "is distinguished by.very many charming productions of various kinds. Here are made: (I) A very fine faience painted on enamel with specially prepared colours; sometimes it is relieved with gold, with or without a gold border; (2) faience in the Japanese style; (3) fine common ware, called blue; and dead white, called Niederwiller; (4) coarser common ware at a low price. A little while ago was also begun the painting of landscapes in different 


\section{FRENCH POTTERY \& PORCELAIN}

colours upon plaques of enamelled faience; these may measure as much as eighteen inches long by twelve wide. Their fragility is remedied by putting a border of gilt bronze to these new pictures, which combine the freshness of enamel with brightness of colouring."

The speciality of Niederwiller is plates and dishes in imitation of grained wood, upon which is placed a landscape finely painted in pink on white, imitating paper; and, that the illusion may be more complete, the corner of the little picture is doubled over as a sheet of paper might be. These landscapes are usually signed Kilian, and dated.

After the death of Beyerle the factory passed into the hands of the Comte de Custine, who entrusted its management to the clever and able Lanfrey, later sole proprietor of the establishment. Two talented modellers worked at Niederwiller: Cyffé, whom we shall find later at Bellevue and at St. Clément, and Charles Sauvage, called Lemire.

It may be useful to collectors to have a list of the works executed for Niederwiller by these two artists.

74 


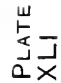

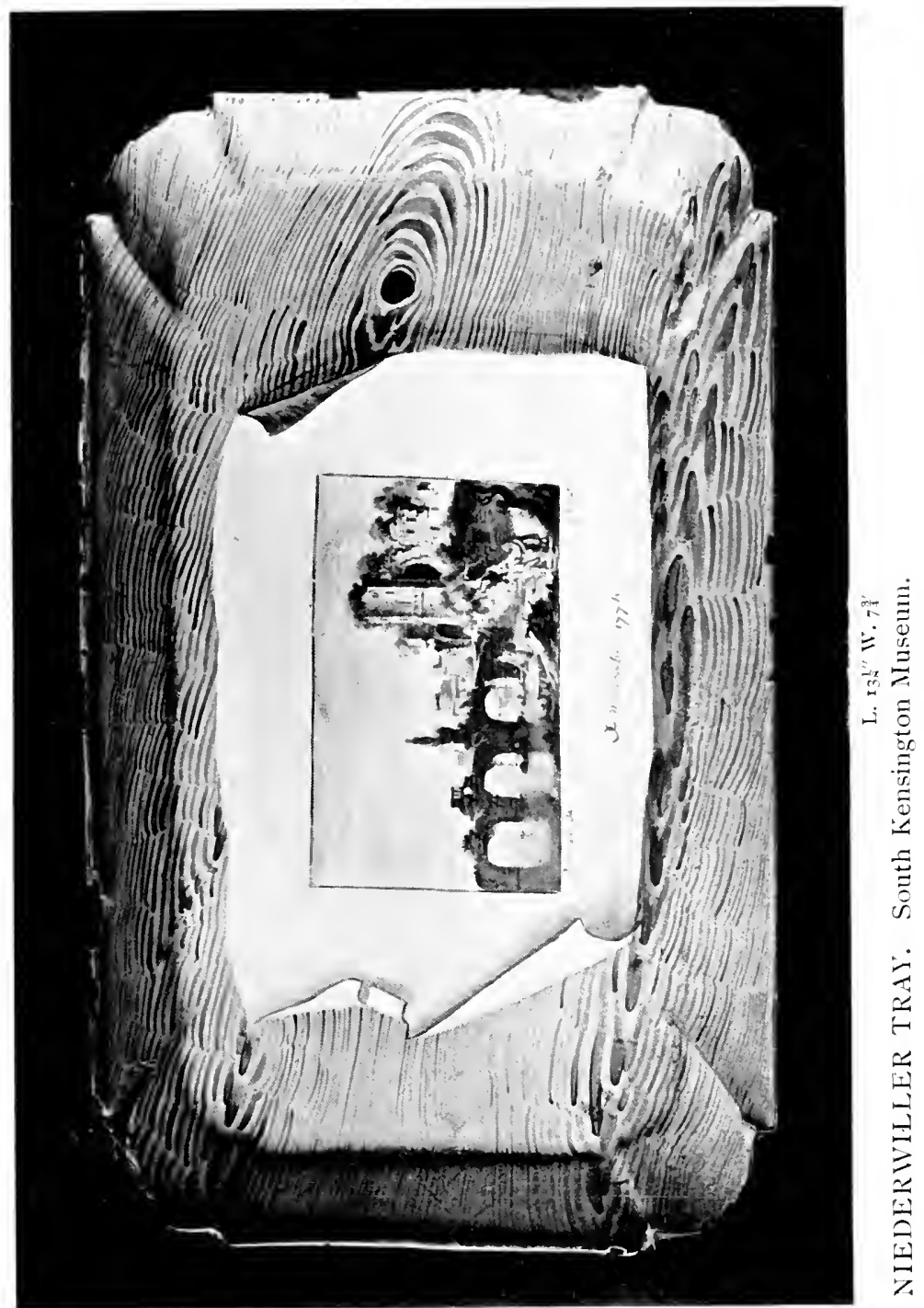



STRASBURG \& ALSACE-LORRAINE

Subjects executed by Cyffle: Chimneysweeps, Savoyards, and companion figures. Pastry-cooks and other salesmen. Beggars and companion figures. Tinkers and hawkers of Paris. Huntsmen with dogs and companion figures. Stocking-darner and companion figure. Spring. Cobbler and companion figure.

Subjects executed by Lemive: Little Cupids. Wafer-sellers. The Muses and Apollo. Seated figures. Painting and Sculpture. Meditation of a Spinner. Bacchus and Bacchante. Apollo and Venus. Jupiter and Juno. Genius with vase. Large shepherd and companion figure. Venus kneeling. Christ. The Rape of Helen. Venus and Adonis, or the Death of Adonis. Shepherd and Shepherdess. The Judgment of Paris. Venus and Bacchus. Bacchante with pedestal. Large Bacchante.

\section{LUNÉVILLE.}

The manufactory at Lunéville was founded in I73I by Jacques Chambrette; it became famous later under the title of "Royal Manufactory of Stanislas," and afterwards under that of "Royal French 


\section{FRENCH POTTERY \& PORCELAIN}

Manufactory." In I750 Chambrette also set up a factory at St. Clément, two leagues distant from Lunéville. Chambrette was suceeeded by his son Gabriel and his son-inlaw Charles Loyal. In the matter of ornament Lunéville attempted the styles of Strasburg and of Marseilles; but the eyes of the least practised amateur will soon perceive the differences between the work of these three famous factories. Let me briefly indicate in what these consist. In Marseilles work the flowers are usually, as may be seen from our illustrations, accompanied by long and very green stalks; in that of Lunéville and Strasburg, on the contrary, they are generally massed into a light compact bunch composed of one or two large flowers, roses, peonies, or pinks. But there is also an essential difference between Luneville and Strasburg: in the products of the former the petals are always much more fully blown. From Lunéville, together with a large quantity of table services, came charming semi-circular jardinières, conceived in the spirit of Watteau and Boucher, open-work baskets copied from Saxony, and lions and dogs, sometimes of 76 


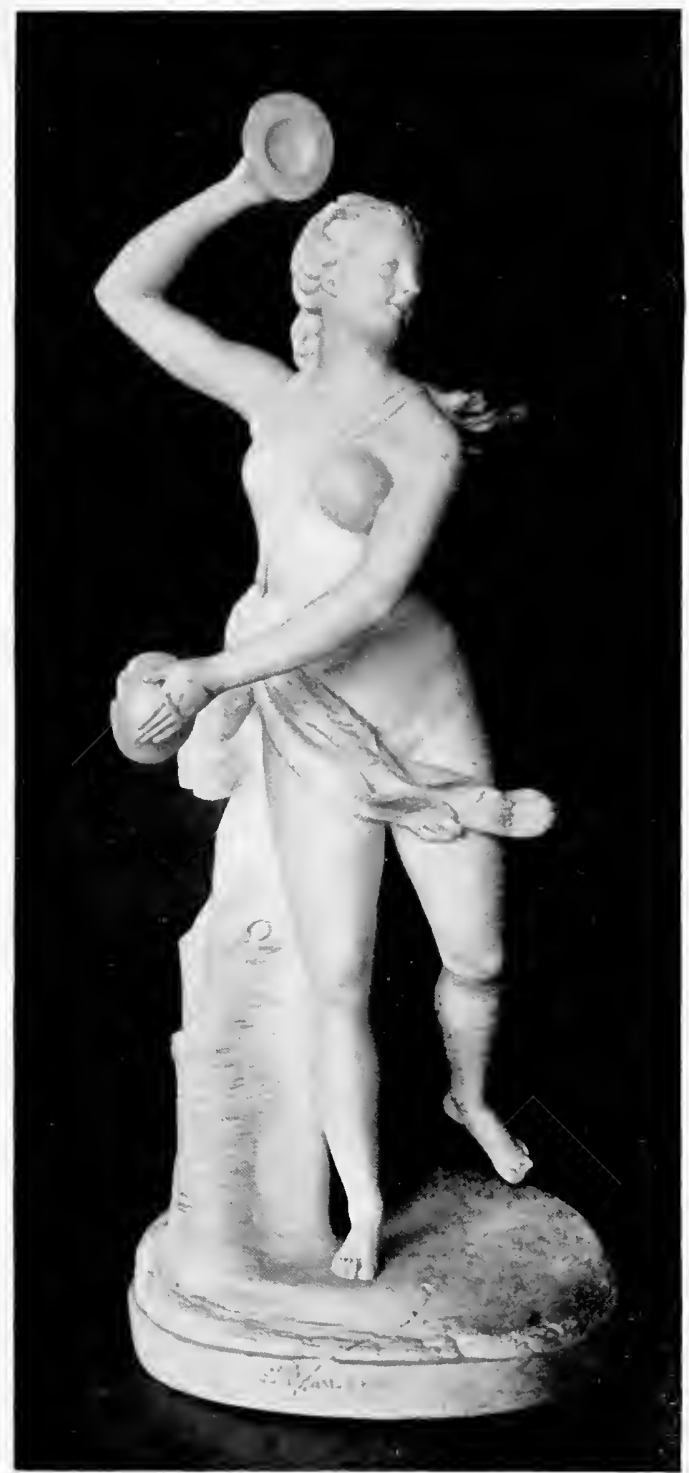

H. $171^{\prime \prime}$

STATUETTE, by Lemire. Niederwiller. South Kensington Museum. 



\section{STRASBURG $\mathcal{E}$ ALSACE-LORRAINE}

life-size. Among the particular specialities of Lunéville, as also of Niederwiller, are the charming statues by Cyfflé, whose original talent had free play here, as it also had later at Toul. Born at Bruges in I724, he went to one of his uncles, a goldsmith in Paris, in order to study sculpture and metalwork. At Lunéville, in 1746 , he executed some large pieces of work in collaboration with Guibal, sculptor to King Stanislas, afrerwards abandoning la grande sculpture in order to produce those little works of household art that we find so charming. After enjoying a high reputation, Cyffle became manager of several faience factories, and afterwards retired to Bruges, where he died in poverty and obscurity.

\section{Bellevue.}

Cyffé also worked for Bellevue near Toul, where a factory had been established in $175^{8}$ by a certain Sieur Lefrançois, whose successors obtained for it, in 1733 , the title of "Royal Factory." Cyfflé made statuettes there, sometimes in pipeclay, sometimes in biscuit-porcelain. 
THE EIGHTH CHAPTER

OTHER FRENCH MANUFACTORIES OF FAIENCE

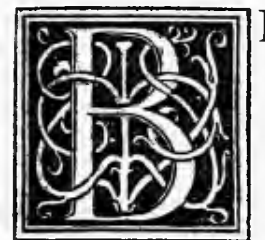

ESIDES the great centres of faience production treated of in the preceding chapters, there have been a certain number of other French manufactories which should not be ignored, although they yield in importance to such places as Rouen, Nevers, Moustiers, and Strasburg. In this chapter we shall give a rapid survey of these factories, which have generally been affected by the great centres in their neighbourhood. Thus, in the north and west the influence of Rouen was greatly felt; in the south Moustiers was imitated by Varages and Montpellier, whilst Strasburg reigned in the east.

\section{LILLE.}

This factory, which allied itself to Rouen, was founded by Jacques Febvrier and Jean Bossu. These men, who were but servile copyists at the commencement of their 78 


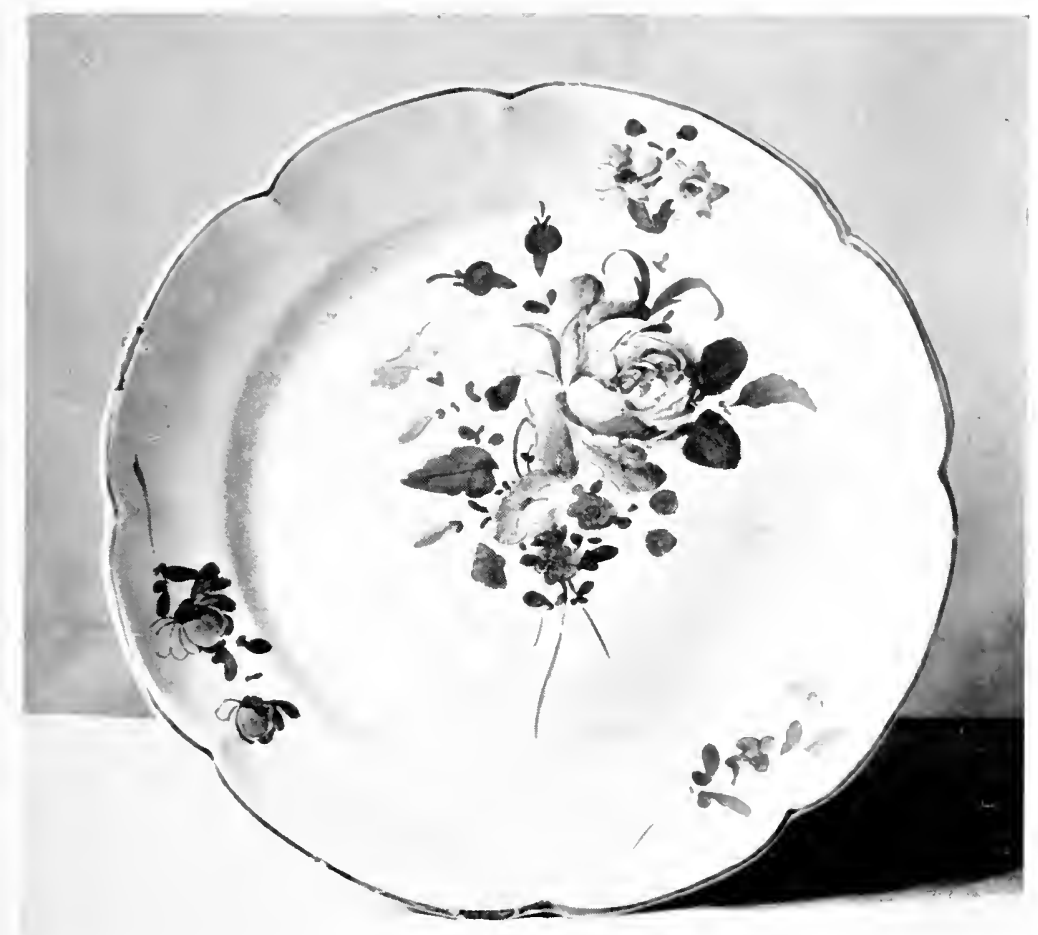

T). 8"

[Photo, D. Freuler, Paris PLATE, of Lunéville Faience. XVIII century. 

manufacture, soon gave to their faience a more individual character, as is shown by the portable altar in the Sèvres Museum, in which a certain Dutch influence may also be traced. Febvrier was succeeded by his son-in-law, François Boussemaert, who brought the products of Lille to still greater perfection, attempting with much success decoration in blue on white, and also polychromatic ornament. Under him, in fact, Lille became one of the great manufactories of Europe, for its three furnaces baked about I,287,600 pieces per annum. Lille faience is often attributed to Delft or to Rouen. Valenciennes is closely related to Lille, and made pretty little figurines in pipeclay.

\section{SINCENY.}

The first factory in this little markettown of Picardy was founded in 1737 by M. Fayard, governor of Chauny, and towards the middle of the eighteenth century it gave occupation to about thirty families. Faience makers from Rouen came in great numbers to settle in that part of the country, as did likewise many from Nevers. Sinceny did a great deal of decorating in blue, en camaieu, 


\section{FRENCH POTTERY \& PORCELAIN}

at the time when it was the fashion to copy China; we also find on a great number of pieces elegant arabesques in the Rouen style, very cleverly imitated either in blue, en camaieu, or in blue picked out with red. Polychromatic designs present a very great variety, and are sometimes remarkable for inventiveness of pattern, and richness and harmony of colouring. There are frequently imitations of Rouen designs (particularly of the cornucopia ornament), sometimes also of Nevers, Strasburg, and Marseilles. Like Rouen, Sinceny made all kinds of different articles, a speciality of this factory being figurines in terra-cotta, representing soldiers in Louis XVI. costume, either on foot or on horseback; these, which were intended as playthings for children, have naturallybecome very rare. We may also attribute to Sinceny plates of the Louis XVI. period, decorated with the crown and fleur-de-lys. This faience is seldom dated. With Sinceny may be classed the factories of Rouy and d'Ognes, whose products are similar. Some of the Sinceny faience is signed in full; the most authentic mark of this manufactory is an $\mathrm{S}$ between two dots. The $\mathrm{S}$ alone is found 80 


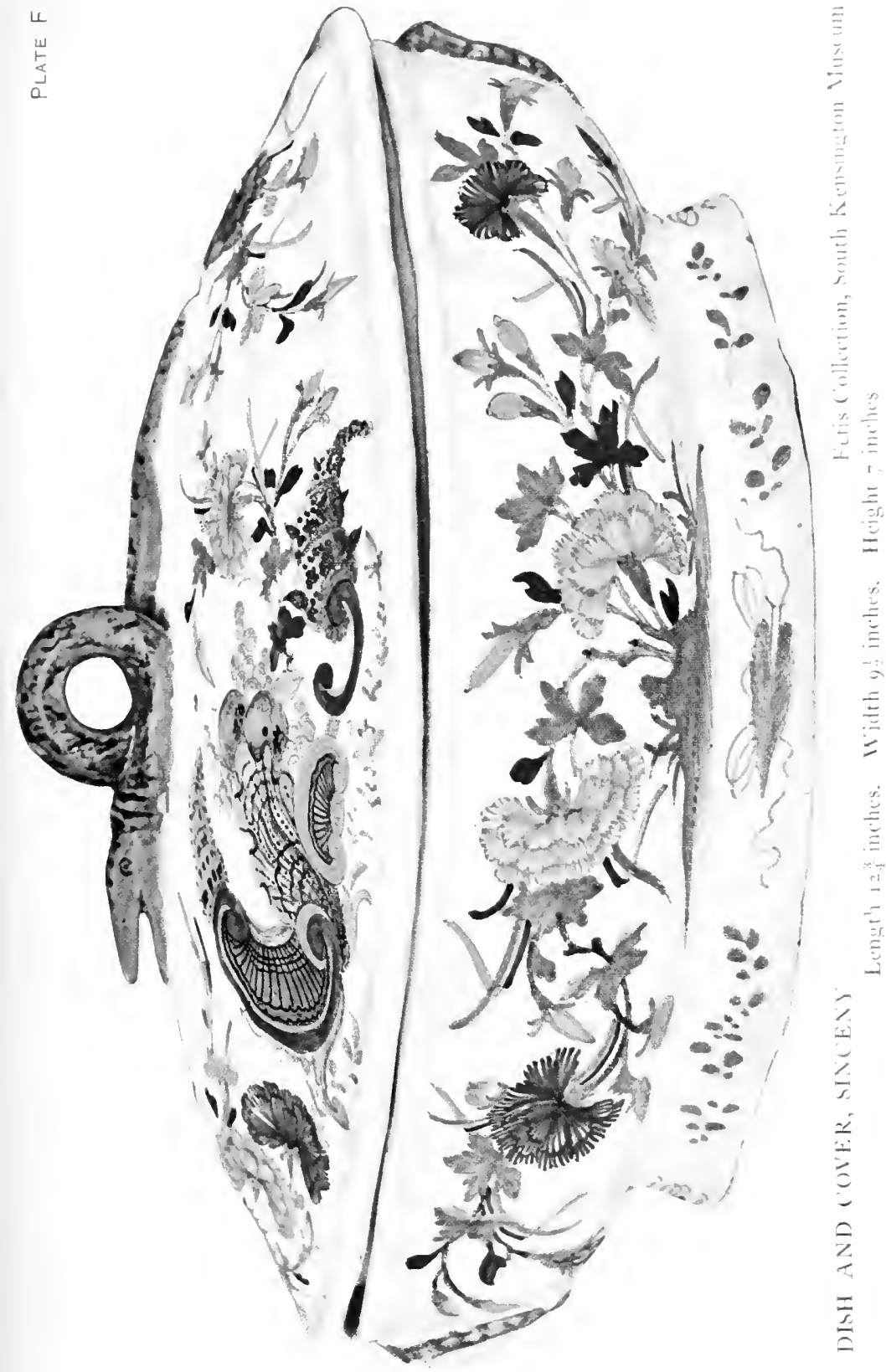





\section{OTHER FRENCH MANUFACTORIES}

on many doubtful pieces. Dr. Wiermont, in his interesting brochure on this subject, mentions having seen on the lower surface of an elegant basket in Sinceny faience the inscription :

$$
\text { L. J. L. C. Pinxit } 1776
$$

The painters Joseph le Cerf, and Bertrand and Claude Borne, worked at Sinceny.

\section{* Sceaux}

Chapelle was the first manager of this factory, and was succeeded by Glot. It was under the management of these two remarkable men that Sceaux produced works whose decoration is so perfect that they may even be compared with porcelain: dishes with coloured ornaments in relief; soup-tureens, the knobs on the lids of which represent some sort of fruit; services decorated with birds; and jardinières ornamented with chubby children who might have escaped from one of Boucher's pictures-in all these Sceaux excelled. The Duc de Penthièvre, Grand Admiral of France, was the patron of this manufactory, whose products are 


\section{FRENCH POTTERY \& PORCELAIN}

often designated by the name of SceauxPenthière.

\section{Saint Cloud}

began by Chicoineau's copying the scalloped ornament and borders of Rouen decoration ; afterwards more original designs were added, great masses of flowers covering the bottoms of the pieces with garlands. The services for the royal households were made at Saint Cloud. Tron was also the manager of this factory, which likewise manufactured soft porcelain.

\section{PARIS}

possessed several manufactories of faience, which in the first half of the eighteenth century was heavy and badly enamelled, and often clumsily imitated Rouen faience. Paris potters excelled in making those beautiful stoves and chimney-pieces in white faience which adorned some of the luxurious mansions of the rich. The whole of that industry naturally fell into decay at the end of the eighteenth century.

82 


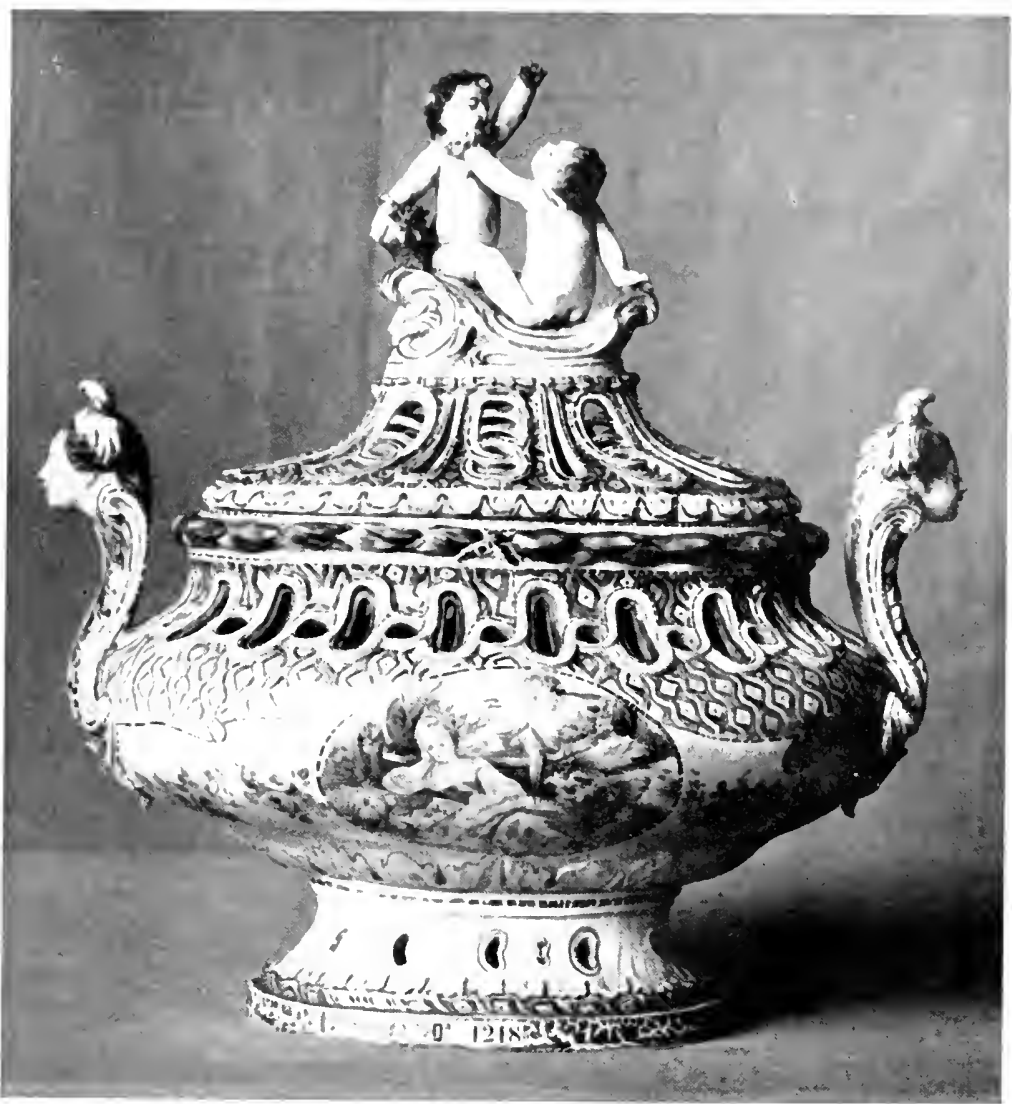

H. $10 !$ "

iPleto, D. Frewler, Paris

FAIENCE OF SCEACX. Sivres Museum. 



\section{APrey}

There was a rather celebrated factory here, whose pleasing floral decorations were the work of the clever painter Jary.

\section{BORDEAUX}

Bordeaux faience, hitherto little known, and insufficiently studied, deserves the attention of archæologists. This was, in fact, the first factory established in the south-east of France at the beginning of the eighteenth century, and for nearly a hundred years it furnished the inhabitants of Bordeaux, and even the Spaniards, with its produce. Jacques Hustin was the great potter of Bordeaux. In I7II he went into partnership with a certain Jacques Fautier, a partnership which was dissolved before r714. His factory prospered throughout the eighteenth century; in three years alone 400,000 pieces of faience issued from its furnaces-a considerable quantity, for the factory had to compete with the produce of Rouen and Moustiers, as well as with the neighbouring faience factories, particularly with Samadet in the Landes, 


\section{FRENCH POTTERY \& PORCELAIN}

whose products are often confounded with those of Bordeaux.

In 1716 Hustin engaged the services of a Dutch workman named Bonte, who helped in executing a number of pieces in fine white enamel coated with blue. Unfortunately Hustin could never succeed with red or gold, and that became the less possible when he was soon afterwards deprived of the valuable collaboration of Bonte, who was burnt to death in a furnace. This occurrence had a determining influence on the fortunes of the Bordeaux factory. Like Strasburg and Saint Cloud, Bordeaux made a good deal of faience in imitation of porcelain.

\section{SAINT OMER}

produced pieces in the Bordeaux style.

\section{SAINT AMAND}

P. J. Fauquez founded this manufactory before I74I. It had four principal decorative styles: the Italian style; the Alsatian (recalling that of Strasburg, and remarkable for its beautiful purple colouring; the pieces ornamented with bouquets are by the painter 84 


\section{OTHER FRENCH MANUFACTORIES}

Fernig, who also worked for Valenciennes, and the flowers by J. B. Desmuraille); the Sinceny style (with Chinese ornamentation); and the Rouen style.

\section{QUIMPER}

This factory attained to some importance in 1743 under the management of Causay, the son of a master faience-maker of Rouen. $\mathrm{He}$ introduced at Quimper the cornucopia ornament, the quivers, and all the polychromatic decoration of Rouen, from which Quimper is distinguished by a paste thicker than that of Rouen, and by designs traced in manganese violet.

\section{Rennes}

This manufacture, as well as those we have now to specify, is inferior in character. The factories of Forasassi and of Bourgouin are known to have existed in $\mathbf{1} 748$.

Montpellier

chiefly imitates Marseilles. 


\section{FRENCH POTTERY \& PORCELAIN}

\section{Montauban}

had several good factories: Ardus, Negrepelisse, Aurillac, Bessols, and Beaumont.

\section{ORLEANS}

executed work in the style of Strasburg.

\section{VARAGES}

chiefly imitated Moustiers, as did also

\section{SamadeT}

in the Landes.

\section{Desvres and Hesdin}

in the north, should be mentioned more for the quantity than the quality of their production. 



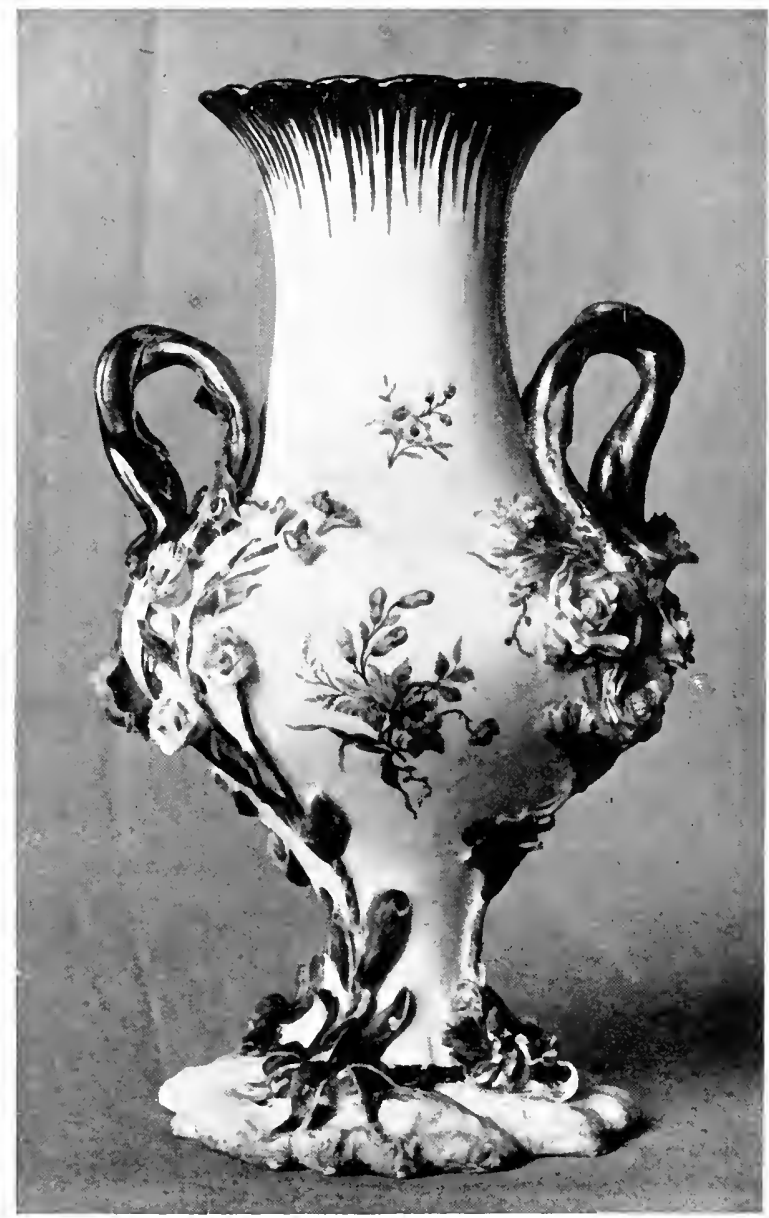

H. 83" [Ploto, D. Freuler, Faris

VASE, in soft porcelain, of Vincemes, I $75^{\circ}$. Sivres Museum. 
THE NINTH CHAPTER

\section{SËVRES}

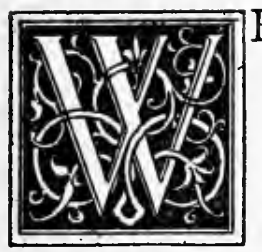

E cannot do better than term Sèvres the Dresden of France. From the workshops of that celebrated manufactory issued the most renowned masterpieces of French porcelain, now exhibited with pride in museums and private collections.

The manufactories of soft porcelain which had been established in France at the beginning of the eighteenth century had not produced works either very new or very original. Except for the blue arabesque decoration of Saint Cloud, the other factories (Chantilly, Lille, and Mennecy) imitated too slavishly the oriental style or the porcelains of Meissen. It was just the time when the delicate achievements of Saxony began to be sought after in France, and French productions could hardly compete with them. This was rendered still more the case by the absence of official encouragement for the French porcelain industry. In the edict of Louis XIV. (1667) concerning the organisation of the "Royal 
FRENCH POTTERY \& PORCELAIN

Manufactory of Furniture to the Crown," established at Gobelins, there is mention of upholsterers, goldsmiths, and cabinet-makers employed under the direction of Lebrun, but no reference is made to ceramic work.

Under Louis XV., thanks to the influence of Madame de Pompadour, that enlightened patroness of the arts, things were changed for the better. A memoir drawn up by Bachelier, a painter engaged at Sevres, of which we shall quote a few passages, will enlighten us anent the beginnings of the manufacture:

"Among the workmen at the manufactory of Chantilly in I740 there were two brothers named Dubois, who had to do with operations on the paste, the glaze, and the clay. Their ill conduct having loaded them with debts, they thought to make something out of the secrets entrusted to them, and presented themselves before M. de Fulvi, well known for his fruitless researches in the manufacture of porcelain. Armed with tempting fragments, they gave themselves out for proprietors and inventors of the process. They were welcomed, and given laboratories in the Château de Vincennes. Money was supplied to them, and quickly squandered. Their conduct 88 


\section{SÈVRES}

opened M. de Fulvi's eyes, and his wrath burst upon them. His threat to send the Dubois brothers away coming to the ears of an intelligent workman named Gravant, this latter resolved to profit by their frequent drunkenness to copy what they had written concerning porcelain, and he gave the result to M.de Fulvi. The Dubois were discharged, and Gravant became the chief workman at Chantilly.

"However, eventually the undertaking became an important one, and a company was formed with rights for thirty years, and the use of all suitable sites in the Château de Vincennes. . . .

"M. Orry appointed M. Hélot to superintend all the chemical processes; M. Duplessis was charged with the direction of the work of moulders, flatteners and repairers, and to preside over it on four days a week. The painting and gilding were inspected every Monday by the Sieur Mathieu, enameller to the king. . . The Sieur Mathieu was thanked and his place was given to the Sieur Bachelier, whose operations commenced in I 748."

In the previous year Louis XV. had given the company a sum of forty thousand 


\section{FRENCH POTTERY \& PORCELAIN}

liores; in 1748 he gave a fresh donation of thirty thousand livres, and again the same sum in 1749 .

The death of the Comptroller-General of Finances, Orry, and of his brother, M. de Fulvi, momentarily endangered the continuance of the manufacture by causing the dissolution of the society. An order of the Council (August I9, I753) reorganised it, limiting the duration of its new licence to twelve years, with Eloi Brichard as grantee. The king authorised the manufactory to bear the title of "Royal Manufactory of the Porcelains of France," to sign with his monogram, and to sell its productions throughout the kingdom. Furthermore, as the Vincennes establishment was becoming too much cramped for room, and as a position nearer the king was desirable, the new factory was established between Paris and Versailles, in the Domaine de la Diarme, previously a summer residence of Lully.

The society's capital was 800,000 livres, the king having subscribed 200,000 .

The secrets on which the undertaking was based became the property of the king. Falconet, sculptor to the king, and Genest, a 90 
Plate Xlvi

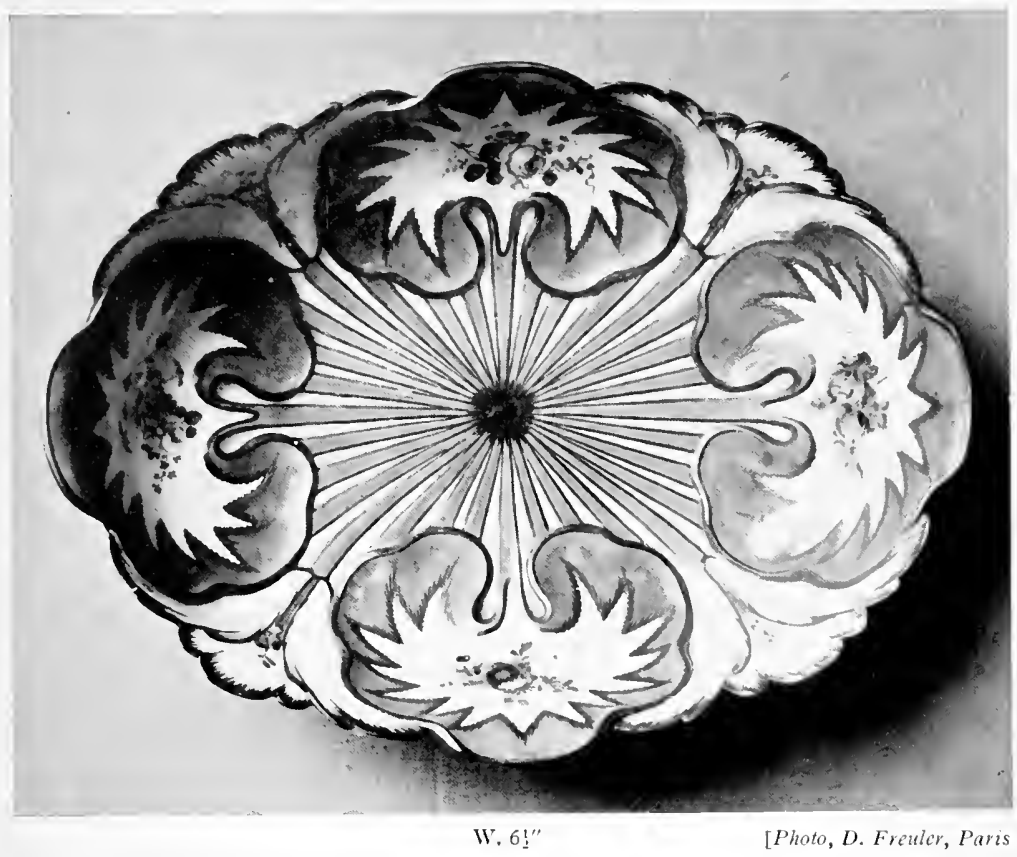

DISH, in Soft Porcelain, Sèvres. I757. Sèves Museum. 



\section{SÈVRES}

talented painter, were added to the staff, which remained under the direction of Bachelier.

From this date Sèvres-or Seves, as it was then called-began to produce with unceasing activity; and its productions became the fashion, almost entirely supplanting those of Saxony. Notwithstanding this, and in spite of its ever-increasing renown, the prosperity of the factory was more apparent than real. Whether Eloi Brichard tried to provide his shareholders with too magnificent dividends, or whether the new buildings had been too expensive, at any rate the company was always on the verge of ruin, pursuing the king and his ministers with complaints and entreaties for money. Instead of granting these petitions and those of the shareholders, the king in October I 759 revoked the licence which should have expired only at the end of i 764 . He had the shareholders' money returned to them, and decided that the establishment should be administered by M. Barberie de Courteille, Councillor of State and Intendant of Finance, with Boileau as director. The king granted the establishment an annual subvention of 96,000 livres from the royal exchequer. 


\section{FRENCH POTTERY \& PORCELAIN}

With this transformation the character of the manufactory completely altered. Vin$\checkmark$ cennes, we must remember, was a private enterprise; Sèvres was nothing of the kind. The directors of the royal works wished to make use of the privileges of their title. They were no longer contented with protection; they insisted upon a monopoly, and they had this proclaimed by a warrant of February 17, 1760, which hardly permitted other factories to make pieces even of plain white or of blue decorated en camaieu. An ordinance of Sartines, Lieutenant-General of Police, dated May 26, 1763 , resumes in two of its articles the spirit of these privileges :

"It is forbidden to everybody, of whatever quality and condition they may be, to manufacture or cause to be manufactured, to model, paint, or gild any work in porcelain under any form whatsoever, to sell or retail it, under pain of confiscation both of the said porcelain and of the materials for its fabrication, of the destruction of the furnaces, and of a fine of 3000 livres.

"It is likewise forbidden, under the same penalties, that any person privileged to manufacture certain common porcelains, 92 


\section{SËVRES}

pottery of white paste or faience painted blue, Chinese style only, shall make use thereon of any other colour, particularly gold, or shall manufacture or cause to be manufactured any figures, flowers in relief, or other pieces of sculpture, unless in order to embellish and to stick to the said works of their manufacture."

French makers of porcelain and faience, ruined by these decrees, bewailed themselves loudly. In order to reassure them, a new edict of February I5, I766, made it known that while maintaining the privileges of the royal manufactory it was yet important to encourage a branch of commerce favourable to the industry of the country. Throughout the kingdom the manufacture was therefore permitted of porcelains in imitation of china, whether in white, in blue and white, or en camaieu in one single colour; on condition that each manufacturer must adopt a special trade mark and deposit it before the competent authorities.

Encouraged by these protective pronouncements, the already-existing factories started work again; other new establishments were opened; and soon paintings of flowers, of 


\section{FRENCH POTTERY \& PORCELAIN}

subject-pieces, of decorations enhanced by borders or by flowers, began to spring up everywhere. But this tide was checked by an edict of May I6, I784, annulling the preceding decrees, and forbidding the factories to produce anything beyond table-services or ordinary pieces. Complaints became yet more unanimous, and the decree was revoked; finally the Revolution put an end to the ques$\checkmark$ tion by abolishing all privileges.

Such, summed up in a few lines, were the relations of Sèvres with the other factories. But how was the manufacture proceeding during this time?

When the king became sole proprietor of the establishment hardly anything was made there except porcelaine de France or soft paste, unrivalled, says Garnier, if we "judge it from an artistic point of view; but of only mediocre quality in regard to domestic use, and far from bearing comparison in this sense with the hard porcelains derived from China or imported from Germany."

Since Boettger, in 1709 , had communicated the secret to Saxony, the rest of Europe had coveted its possession, and France sought by every means to enter into rivalry with the 94 
Plate Xlvil

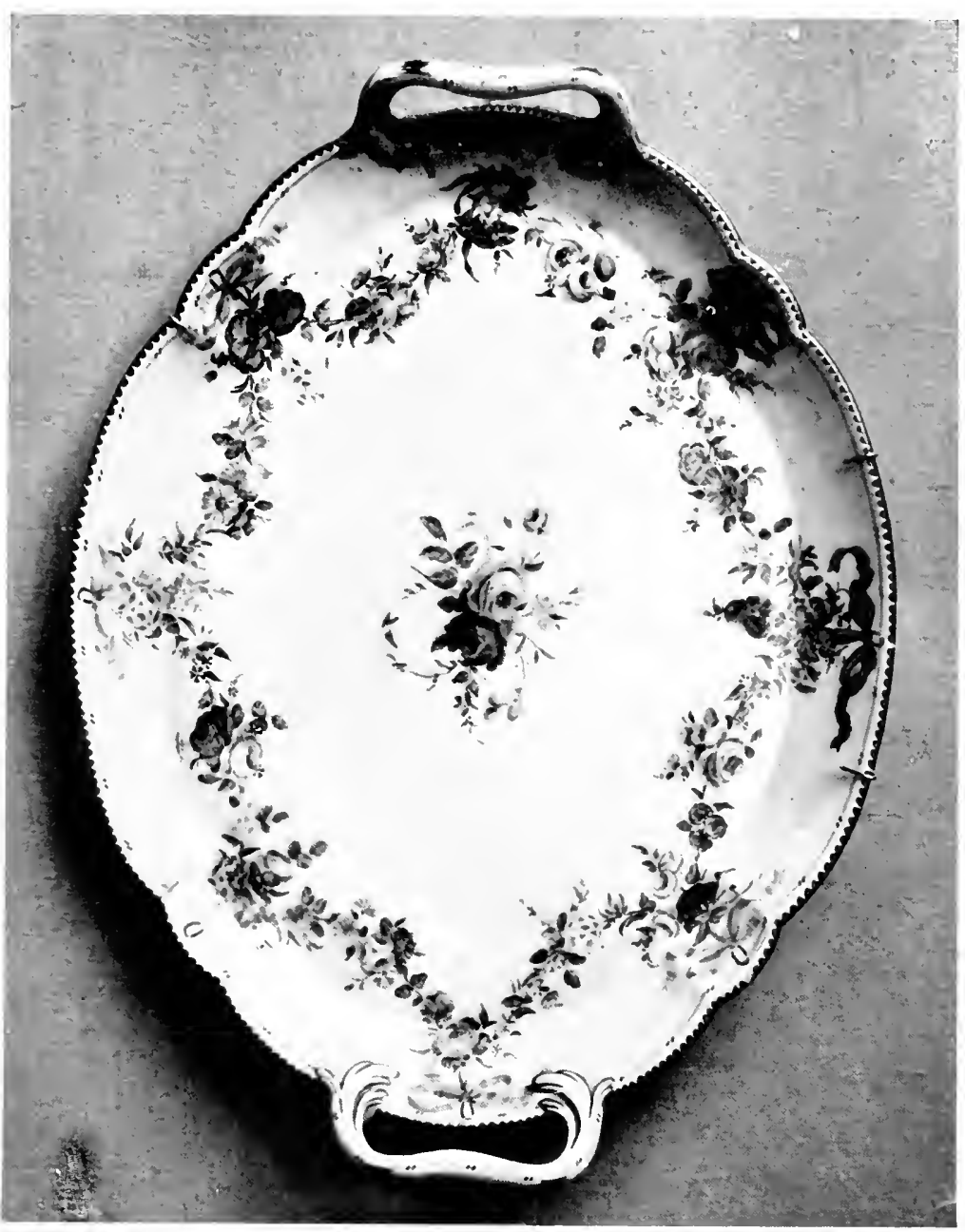

W. 10 !

[Photo, D. Freuler, Paris TRAY, of Soft Porcelain, Sères. I759. Sirres Museum. 



\section{SËVRES}

manufactory of Meissen. Thus Sèvres accepted the offer of two German workmen, Busch and Stadelmeyer, to impart the secret of the Saxon porcelain; but they had to be dismissed after several fruitless experiments which cost no less than 26,000 livres. Another workman, named Jacques Henri Wackenfeld of Anspach, proposed to the magistrates of Strasburg to start a porcelain factory at their expense. After two years of fruitless endeavour the German workman ended by associating himself, in I 721 , with Charles Hannong, the great faience-maker of that town. Their exact relations are not known; but it is certain that Wackenfeld was soon got rid of, and Hannong continued to make his porcelain alone.

M. Jacquemart has had in his hands one of Hannong's first productions. "It is," he writes, "a charming little oval salt-cellar with corbels decorated in a pale red-gold. The paste is too much like felspar and as though vitrified, tending to sag in the fire. Nevertheless the maker failed not to sign his production with an $\mathrm{H}$ in blue."

In our chapter on the faience of Strasburg we have spoken of this powerful dynasty of 


\section{FRENCH POTTERY $\mathcal{G}$ PORCELAIN}

the Hannongs, and we shall here only consider their production of porcelain in relation to that of Sèvres.

Paul Antoine Hannong continued the experiments of his father, aided by a certain painter named Lowenfinck, thanks to whom Strasburg porcelain made great advances. The Sèvres manufactory was not slow in recognising this redoubtable partnership, and called Paul Hannong's attention to the decrees which granted it exclusive privileges. The Strasburg potter, alarmed, tried to shelter himself from prosecution by begging for letters-patent; these were refused him, and as a last resort he came to Paris, and offered to treat with Sèvres for the cession of his secret. On September I, I753, a deed was in fact drawn up which never came into effect, it being soon discovered that, with the secrets mentioned in this deed, Hannong also made use of other materials. Unable to profit by his discoveries, Sèvres prosecuted him, and a decree of 1754 obliged him to cease the manufacture of porcelain and to destroy his furnaces. Paul Antoine went into exile, and at Frankenthal in the Palatinate founded a factory which became prosperous. His son 96 


\section{SÈVRES}

Joseph Adam, who succeeded him in the direction of the new works, endeavoured in vain to come to an agreement with Sèvres. His second son, Pierre Antoine, succeeded better; on July 29 , I76I, a convention was concluded between him and the director of the French factory, by which he divulged all the processes of the manufacture of hard porcelain. Only at the last moment was it discovered that certain elements of the secret were lacking, and to get rid of Hannong he was made to sign the cancelling of his bargain in consideration of 4000 livres down and an annual pension of 1200 livres.

While these events were proceeding, resulting virtually in a complete check on that side, the composition of the hard paste had been discovered in $175^{8}$ by the Comte de Brancas Lauraguais in the department of L'Orne. In 1756 Guettard had discovered the deposit of Alençon, and after experiments made at Bagnolet had obtained a true porcelain, though somewhat brownish.

It was, however, a chance circumstance $\sqrt{ }$ that procured for Sèvres the secret so long sought for. Madame Darnet, the wife of a surgeon of Saint-Yrieux near Limoges, 


\section{FRENCH POTTERY \& PORCELAIN}

remarked in a ravine some white and sticky clay, which seemed to her suitable for use instead of soap in the washing of linen. She told her husband of her discovery, and he, suspecting the value of this clay, took it to Villaris, a Bordeaux apothecary, who, after several chemical tests, recognised the true character of the kaolin. They therefore sent some specimens from the deposit to a Sèvres chemist named Macquer, and these yielded a perfect result.

In I768 Macquer took possession of the deposit, and in 1769 the Academy"of Sciences beheld the first vases in hard porcelain produced by the works of Sèvres.

The manufactory had at last achieved its end; but Boileau did not long enjoy success. He died in 1773 , leaving a sum of 300,000 livres in the coffers, and an equal value of goods in stock. His successor, Parent, an intelligent but unbusinesslike man, wasted it all in six years, and even committed such indiscretions as brought him to prison.

As successor to Parent the king appointed Régnier, under whose direction the first considerable output of hard porcelain began, noteworthy among which were the fine vases 98 


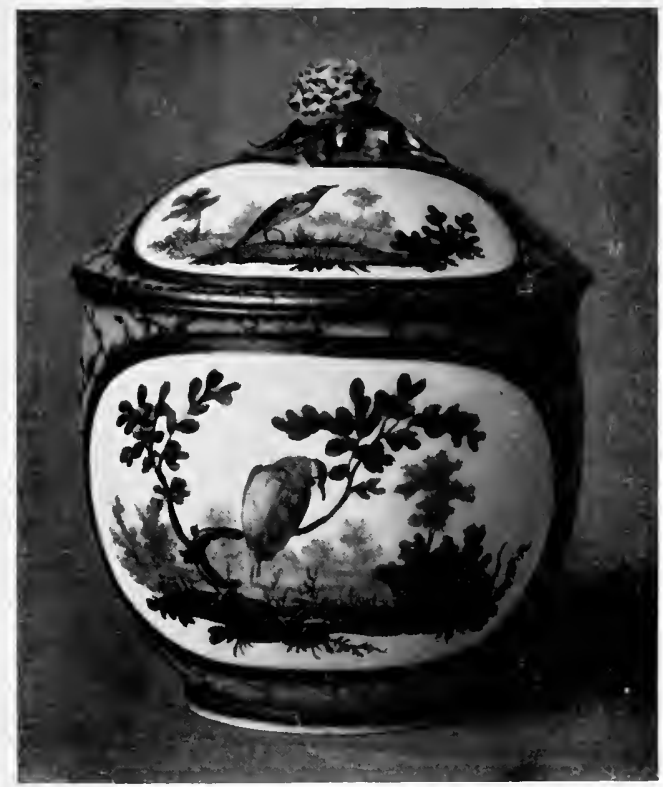

H. $4^{3 \prime \prime} \quad[$ Photo, D. Freuler, Paris

JAR, with Cover, in Soft Porcelain, Sèves. г 76 r. Sèvres Museum. 



\section{SËVRES}

that adorned the palace of Saint-Cloud (destroyed in 1870 ), and several pieces now at the Louvre.

The Sèvres manufactory was in its zenith at the beginning of 1789 . Foreign sovereigns disputed for the possession of its productions. But soon the sinister events of that period, which ruined nearly all the flourishing manufactures of France, paralysed its activity for at least several years; the suppression of privileges, the financial embarrassments of the Government, the difficulty of supplying the Exchequer-all contributed to this result. The mathematician Montucla, Accountant of the General Upkeep of Royal Buildings, wrote on this subject to the Comte d'Angiviliers, Superintendent of Fine Arts :

"The more I reflect, Monsieur, the more I am convinced of the necessity of managing to reduce the output by a full third. All that tends to support these luxuries will be paralysed for several years. Paris is being wiped out by degrees. All the rich people are going off to plant cabbages at their country places. You see the house of Artois is ruined for years to come. There are going to be stringent reforms in the king's household, in the 


\section{FRENCH POTTERY \& PORCELAIN}

queen's, in Monsieur's. And with all this having in January to pay up for two months at 16,000 to 17,000 livres each. . . . Except for some expedient which I do not see, it appears to me that we are in imminent danger. ...."

In 1790 there was momentarily question of selling the factory; it was only the fear of a disadvantageous sale that decided Louis XVI. to keep it on, and he wrote with his own hand at the end of the report:

"I shall keep on the manufactory of Sèvres at my own expense; but I desire that the expenditure shall be diminished and regulated so that it does not exceed I00,000 crowns, and that from the end of this year the monthly wages of the workmen shall not exceed 12,000 livres. Debts are to be paid off out of receipts from sales, and I wish no more to be contracted, which should be easy, as I am going to supply funds each month charged as expenses of my buildings.

"I desire that an economical scheme of administration from now to the end of the year be drawn up. An exact account is to be kept both of whatever is made for me, and also of the balances due to me from sales IOO 


\section{SÈVRES}

after debts have been paid off, so that I may judge with full knowledge whether to keep it or to get rid of it in a more advantageous manner than could be done at the present moment.

"At Saint-Cloud, August 7, I 790."

The suppression of the factories of Sèvres and Gobelins was violently demanded by the blind bigots of the revolutionary assemblies; but happily it was decreed in I79I that the royal manufactories should neither be confounded nor alienated with the national possessions, but that they should be left as charges on the Civil List created in favour of Louis XVI. At the Convention in 1794 the Minister Paré spoke in these terms:

"It must be confessed that these establishments, originally dedicated to luxury and an ostentatious magnificence, would by the nature of their productions lend themselves with difficulty to commercial speculation. Different suggestions have been made as to the utilisation of these manufactories. Make tapestries, they say, at cheaper prices. Make less perfect porcelain, make imitations of English earthenware. . . This would be to convert the manufactory of Sevres porcelain 


\section{FRENCH POTTERY \& PORCELAIN}

into a manufactory of faience. I think the manufactory must continue what it is; but if necessary the output should be reduced, or at least proportioned to the orders that may be given or to the sale that may justly be expected."

Thus the manufactories were saved; but during the revolutionary period their lack of money was such that the Government had to distribute corn and food from the stores of the State to the artists and workpeople. After passing through these turbulent times, so inimical to art, under the administration of Batelier, the representative of the people, and afterwards of Chanou, who usurped his place, Sèvres enjoyed quieter days under the triumvirate Salmon, Meyer, and Hettlinger (until I800). The savant Alexandre Brongniart was then appointed director, and began by achieving wise reforms. His active and able direction lasted forty-seven years.

His worthy successor was Ebelmen (1847I852), to whom succeeded Victor Regnault, a member of the Institute, who held the post until the beginning of 1870 , and was then replaced by Louis Robert, chief of the painting-rooms. In March I879, he was made IO2 


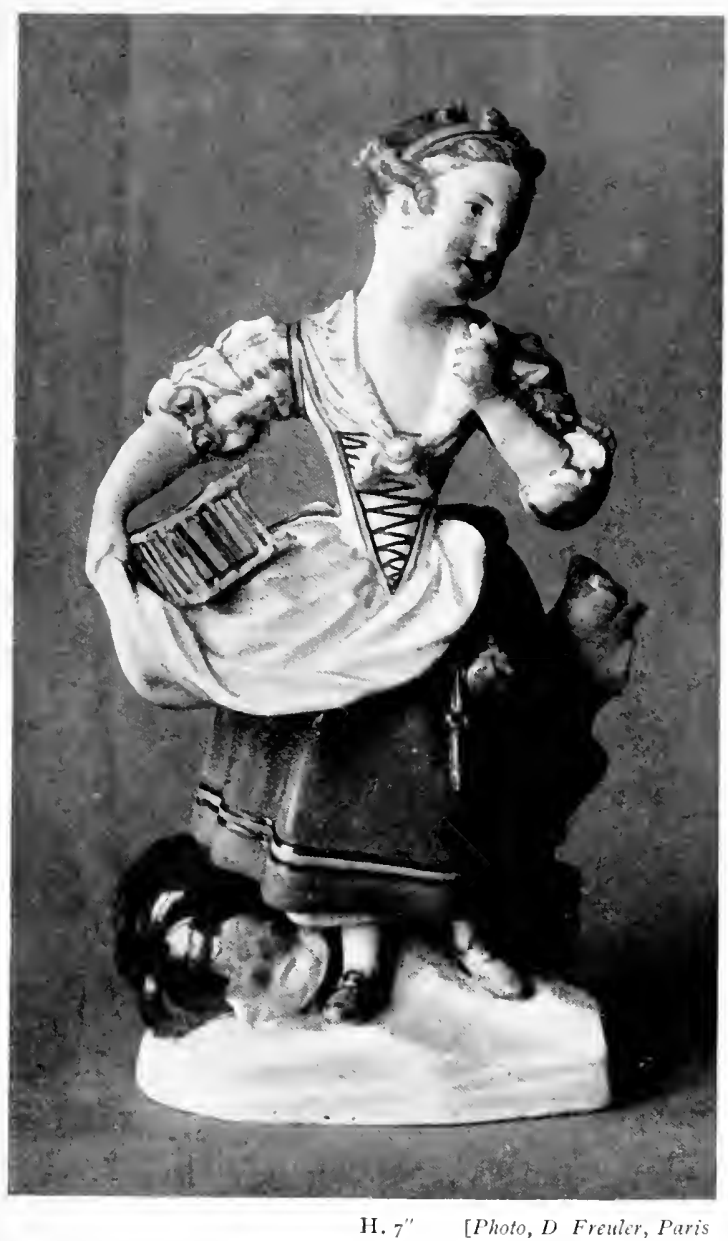

FIGL'RE, Soft Porcelain, Sèvres. I 762 . Sèrres Museum. 



\section{SËVRES}

honorary administrator, and had for successors, M. Ch. Lauth (I879-1887); M. Th. Deck (I887-I89I); and finally M. Baumgart, administrator, and Messrs. Coutan and Vogt, directors, since $\mathbf{r} 89 \mathrm{I}$.

Under the old régime the manufactory had no fixed income. In I790 Louis XVI. allotted it 100,000 livres a year; in 1805 it received 264,000 francs; in 1850 its annual grant was 350,000 francs; it is now 624,000 francs.

It would be overstepping the limits of this study to pass in review the names of all those associated with the manufactory; but I should be sorry not to mention the most celebrated among them: the sculptors Caffieri, Larue, Boizot, Bachelier, Duplessis, Falconet, Duru, Clodion, and Le Riche: the modellers of ornaments and flowers Himbert, Madame Caton, and Mademoiselle Chanou; the painterdecorators Armand junior, Aubert, Lebel junior, Capelle, Castel, Dodin, Comery, Micaud, Morin, Pithou junior, Vieillard, and others.

The productions of Sèvres were formerly especially dedicated to diplomatic presentations. Here are some of these celebrated gifts : 


\section{FRENCH POTTERY \& PORCELAIN}

October I, I76I-Sent to the Queen of Spain a service in French porcelain . . . 13, IOI

June 24, 1763 -To the Duchess of Bedford, a service of Sévres . $\quad . \quad$ • • I8,374 January 5, 1767-To the Comte de Stahremberg, ambassador, one service . . . . $\hat{\jmath}^{2,523}$

September I5, I783-To the Duchess of Manchester, wife of the English ambassador, a service in Sevres. . . • . . 19,872

December 30, I783-To the Duchess of the Asturias, two vases, four groups, and one tea-service .

July, I784-To the King of Sweden, travelling in

France, a service with vases and groups in biscuit china

October, 1784-A gift of the same kind to Prince Henry of Prussia

June, I786-Vases and groups presented to the Archduke Ferdinand, Governor of Lombardy . • • • . . . . 24,073 August, I786-A similar gift to the Archduchess Christina and to her consort the Duke of Saxony - 24,476

The entire list would be lengthy, and we confine ourselves to these few examples; but these diplomatic presents having become more rare, many objects from Sèvres are assigned to French or foreign museums. The ancient custom of presenting porcelain to persons who have rendered more or less effective services to the State is likewise kept up. I 04 


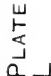

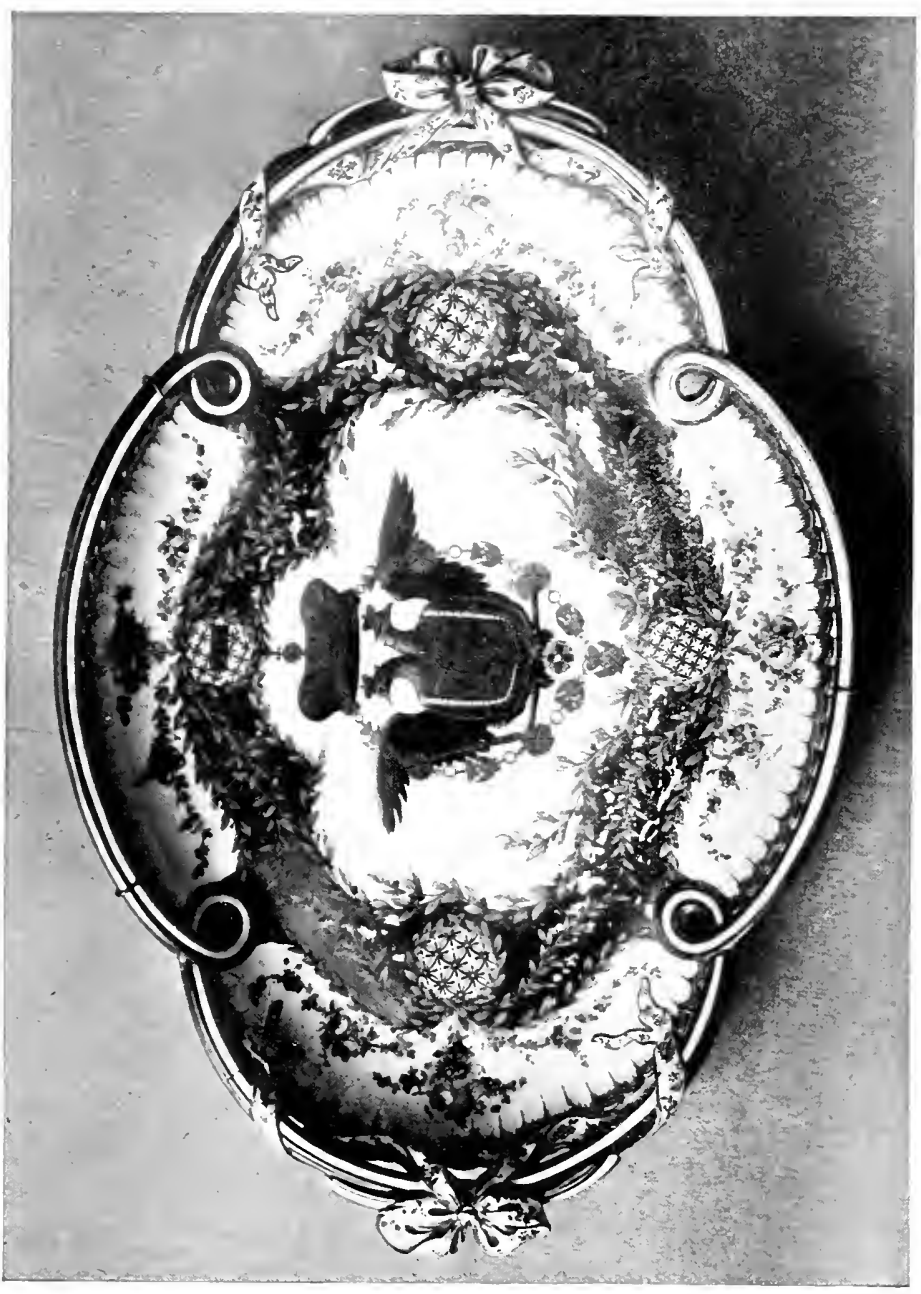

ב⿱

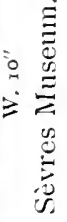

它

㲔

ב⿱ 



\section{SÈVRES}

The manufactory now possesses a shop in Paris for the disposal of its productions; but whether the public does not care to see the State acting as merchant, or whether the porcelains of Sèvres are less perfect than formerly-the sales do not exceed 100,000 francs $(£ 4000)$ per annum.

Having thus briefly narrated the history of the Sèvres manufactory, we must now attempt to give some description of the chief works issued from the celebrated establishment - works which are nowadays either unobtainable, or only to be bought at enormous prices. Such are in especial the softpaste productions of the Louis XV. and Louis XVI. periods, which are the more valuable as so few of them remain extant; many perished during the Revolution. England has taken from us much of our finest Sèvres porcelain, and the most precious examples are above all to be found in the magnificent Wallace Collection and in the collections of Windsor Castle. King George IV. had a passion for this porcelain, and when he was Prince of Wales he had among his household officials one named Benoit who made frequent journeys to France with the 


\section{FRENCH POTTERY \& PORCELAIN}

sole object of procuring specimens. One cannot, indeed, imagine anything more delicate and perfect than this porcelain with its milky and fluid enamel, on which the bouquets in relief show the fresh and velvety tints of flowers. And besides, what variety, what richness of colouring! We have in turn that cobalt blue termed bleu-de-roi; the sky-blue called turquoise, invented by Hellot in $175^{2}$; the rose Pompadour, which dates from the time when that woman of genius was in fashion; the rose Dubarry, paler than the preceding; the violet pensée (pansy-violet); the jaune-clair or jonquille (pale yellow); the vert-pomme or vert-jaune (apple green); the vert-pré or vert anglais (grass-green).

M. Garnier has clearly explained the composition of this paste and the method of its manufacture: "The paste of this exquisite porcelain," he writes, "was composed of Fontainebleau sand, saltpetre, sea-salt, Aliante soda and alum, with gypsum or flakes of alabaster. All these materials mixed together were put in a furnace, formed there into a mass one foot thick, and left to bake for at least fifty hours. They emerged as frillea vitrified and perfectly white paste. This I06 


\section{SËVRES}

frille, well pulverised, was then mixed with Argenteuil clay, in the proportion of nine litres of frille to three litres of clay, thus forming a paste which was worked up in a mill for about three weeks; it was next set to dry in troughs, then crushed by means of cylindrical rollers, sifted, and, moistened with water, was formed into balls to which soft-soap and boiling water gave plasticity.

"The preparation of the glaze entailed no less care: it was composed of Fontainebleau sand, litharge, soda-salt, silica, and potash, all which materials were pounded and mixed together; they were then melted under the furnace in crucibles until they crystallised, and were then reduced to powder, which, with the addition of water, formed a bath of enamel.

"The pieces were once fired in the biscuit state, and then enamelled by sprinkling, and not by immersion; so as better to make the enamel adapt itself to the biscuit, a little white vinegar was mixed with it at the last moment.

"As will be perceived, soft porcelain is a kind of vitrification, the texture of which is so exceedingly fine and close that the nonenamelled portions offer a softness to the 


\section{FRENCH POTTERY \& PORCELAIN}

touch-one might term it a velvety qualityby which they may almost be recognised.

"But what above all constitutes the superiority of the soft paste is the lustre it gives to the colours, which seem to be identical in substance with the enamel itself, having to a certain extent sunk into it, and having been fused with it. This is one of the distinctive signs of this porcelain, and by this, in default of other characteristics, it may be recognised. When one looks at a piece of soft porcelain obliquely to the light, so that the light strikes partly on a painted portion and partly on a piece of white surface, no difierence is noticeable in the glazing of the two portions; all exhibits the same limpidity of quality. If, on the other hand, one examines a piece of hard porcelain in the same manner, a distinct difference will be perceived; however well the colours are glazed, they will appear less brilliant than the rest of the surface, and of a different texture."

When we consider the various productions $\checkmark$. of Sevres, we find that they may be classed in four principal categories: table-services, vases, biscuit-porcelain, and pictures.

Like all manufactories, Sèvres produced 108 


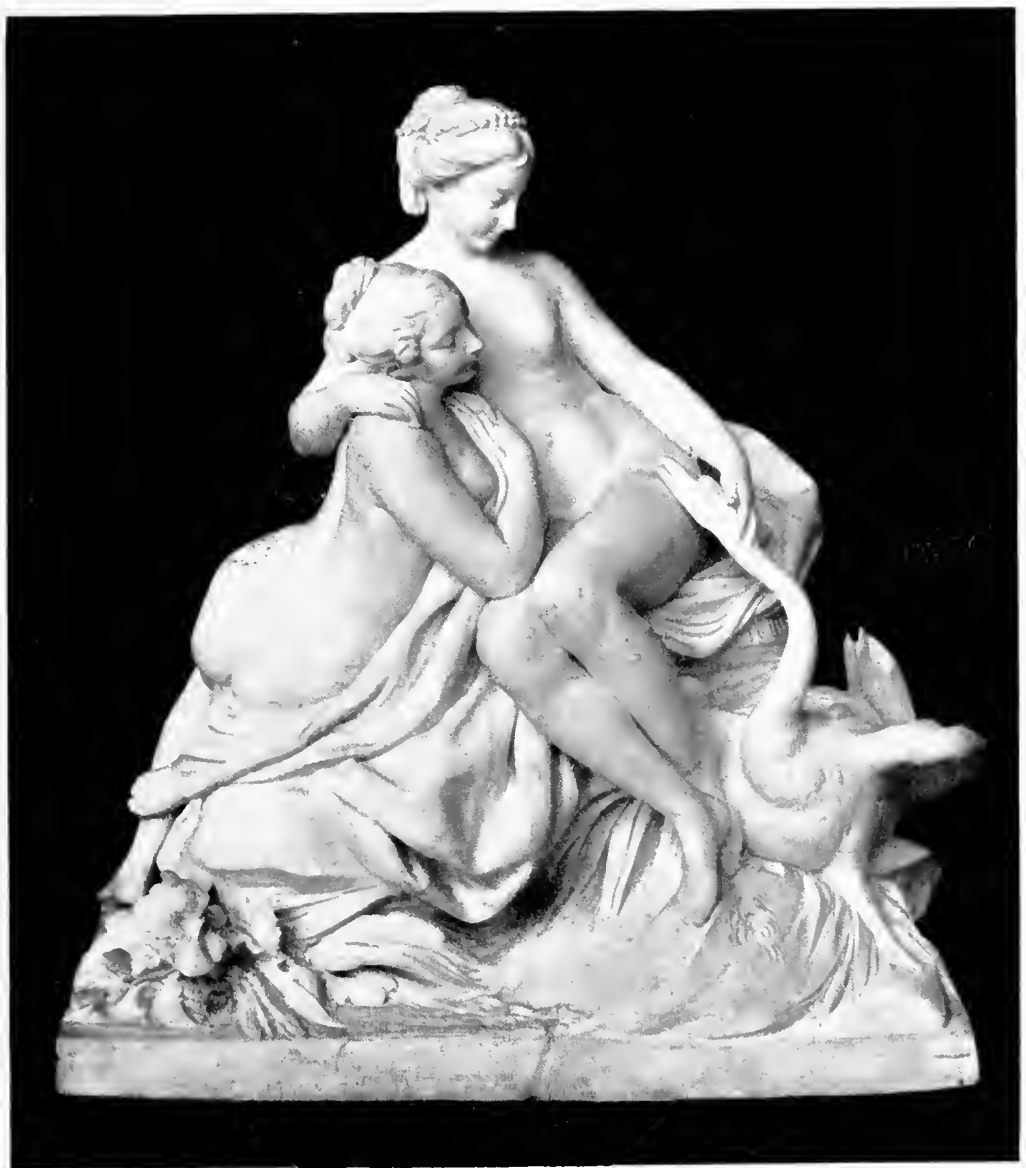

I1. 13 "

SEVRES GROUP. South Kensington Musenm, 



\section{SÈVRES}

an immense number of services and objects of utility. Duplessis, goldsmith to the King, made a great many coffee-pots, teapots, and seals, with which fault may be found on the ground that their shapes sometimes too closely resemble designs for goldsmith's work. Pieces of the first period are often adorned with flowers or foliage in relief, designed not only by Duplessis, but also by Thouret, Paulin, Boizot, and others. Then, after the models in rococo style, in 1745 there appeared the cylindrical cup, often considered as of the Empire period, but which really preceded it, just as did the sphinx and other models which the Empire merely modified. In all the productions of the first period, the white of the porcelain is always very much seen: the little flowers, nosegays, or wreaths in the most delicate tints, are scattered sparsely over the background of pure white enamel, never usurping a too prominent place, and always leaving the whiteness of the porcelain predominant. The decorators of this period understood thoroughly that the essential, fundamental colour of the material should not be hidden, and that decoration should remain decoration. 


\section{FRENCH POTTERY \& PORCELAIN}

Later, however, decoration took the upper hand, and coloured grounds began more and more to cover pieces which formerly they would merely have decorated; gilding, too, became thicker and occupied more space. Until I 770 neither in the soft paste porcelain nor in the hard did the forms of decoration change much, except for the alterations I have just mentioned. It always consists of flowers, wreaths, or sometimes little landscapes. But after that date we find a double transformation : as regards subjects we note the appearance of painted portraits on the pieces; while as regards shapes, great modifications were introduced, Etruscan or Egyptian designs supplanting those of Louis XV., or Louis XIV. The porcelain itself still more tends to disappear almost entirely under gold, greens, purples, and yellows; portraits by Isabey of great dignitaries of the Empire, mythological scenes, marine views and landscapes fill up all the space.

The same tendencies persist under LouisPhilippe. The Peyre cup, subsequently adopted by the entire porcelain industry, dates from I845. Since that period the manufactory has continued to copy the styles of the past too I IO 


\section{SËVRES}

frequently-an error in principle; for is it not an indisputable truism that every period should have a style of its own? If the decorators of Louis XV. had been content to copy those of Louis XIV., we should have had neither the Louis XV. style, nor the Louis XVI. style, nor the Empire style, which, it will be admitted, would be a loss.

The vases are perhaps among the most celebrated pieces issued by the historic factory, and have, on the whole, attained the highest prices. When only soft porcelain was made at Sevres it was not possible to achieve very large pieces. But what exquisite masterpieces, enhanced by what marvels of modelling, were then issued from the works! The most beautiful of them are to be seen in the Wallace Collection at Hertford House. There are to be admired Duplessis's vases on which four medallions of cupids playing among clouds stand out upon a beautiful green ground; and the Vase Vaissean à Mat with its medallions upon a royal-blue ground, its grotesque lion-masks to right and left, its white flag strewn with fleurs-de-lys, its birds so charmingly painted within a blue framework. Another important piece in this same 


\section{FRENCH POTTERY \& PORCELAIN}

collection is the inkstand of Marie Leczinka. The ink-pot, covered with a royal crown, stands upon an oval tray, the green ground of which is crossed by four white bands, leaving two medallions on which are depicted cupids holding crowns. To mention some other celebrated examples of this series: there are the Vase Ovale with goats' heads; the $V$ ase Militaire ornamented with flags; the Vase aux Tritons supported by three tritons modelled by Delarue; the Vase a Anses, with elephants' heads forming the handles; the $V$ ase Ruche d'Abeilles (Beehive Vase); the $V$ ases à côtes torses (ribbed); the pot-pourri vases ; the Vase Tulipe à oreilles; the Vase $\dot{a}$ l'A mour Falconet, terminating in the shaft of a column surmounted by a statuette of the celebrated sculptor; the Vase Paris, one of the largest in size; the Vase Bachelier des Saisons with twisted cannelating of its stand; aud the Vase Comete. At the same time as these vases Sèvres was also producing jardinières, baskets, épergnes and clocks.

After I 780 Sèvres endeavoured, above all, to make vases larger than those manufactured in Saxony. The first great vase issued by Sèvres was the Vase Medicis (Musée du I I 2 


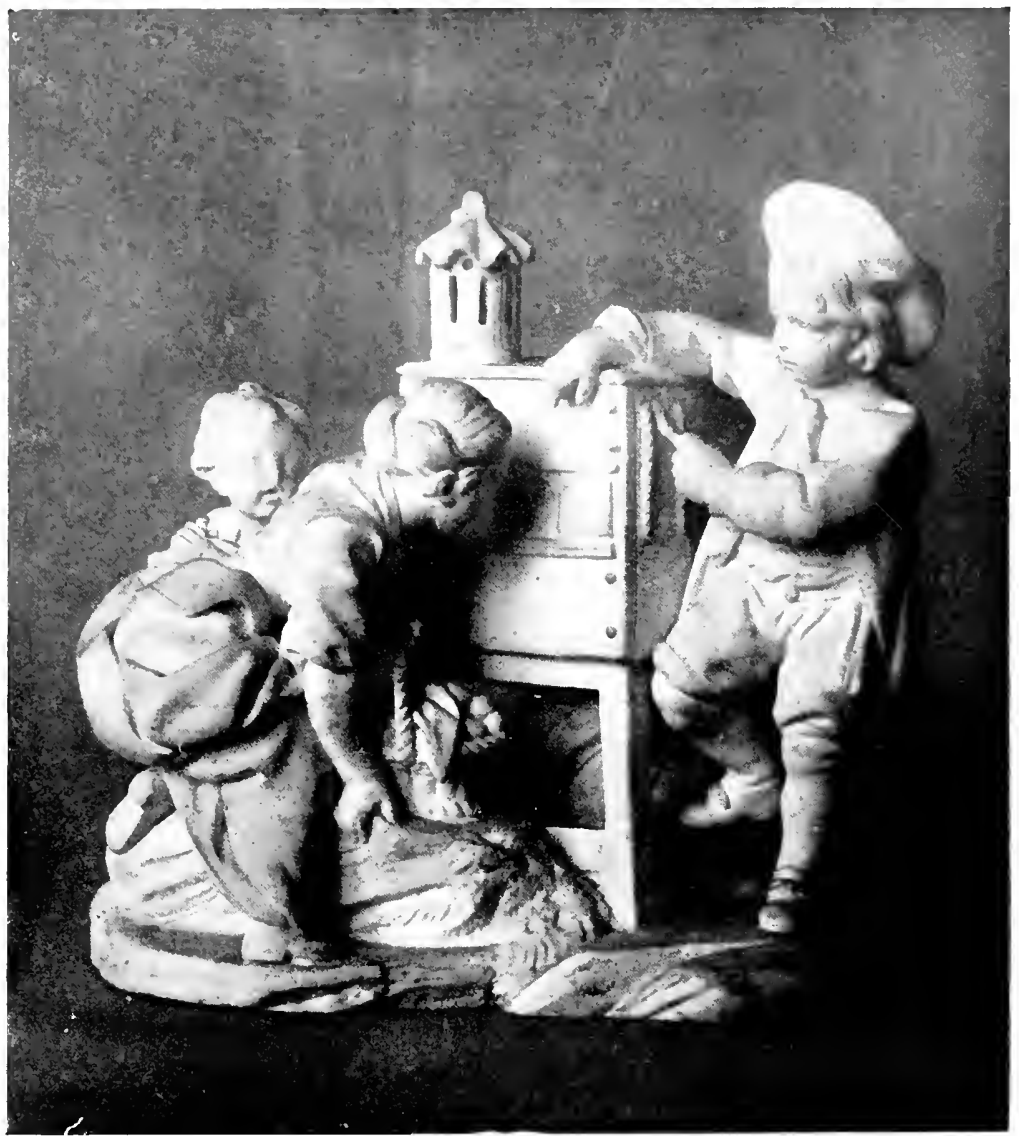

H. $6^{\prime \prime}$

L Photo, D. Freuter l'aris

GROUP, in Soft Porcelain, Sivres. Before I Soo. Sèvres Museum. 



\section{SËVRES}

Louvre), two metres in height, executed in I 783 after a model by Boizot, composed of a circle in biscuit-porcelain, with sculptures framed in panels, the bronzes chiselled by Thomire. That admirable goldsmith also mounted otherSèvres pieces. I am acquainted with two such, in the collection of a Parisian merchant, which I had occasion to describe and study in a French review a few years ago.

In these large vases we perceive the same alterations of form and style as in the services: a progressive evolution from the styled $d$ coquille towards the severer and straighter style of the Directory and the Empire. Under the latter régime Sèvres produced a fair number of great vases: the Vase Cordelier (1801), the Vase CEuf(1802), the Vase Fusean (1803), the Vase Percier (1804), and the Vase Etrusque. Of the same period are the great Coupe de Fragonard; the Surtout-de-table Olympique (the Olympic épergne), with Napoleon I. upon a triumphal car ; and the Surtout Égyptien (Egyptian épergne).

The biscuit-porcelain statuettes of Sèvres are also among the chief glories of the manufactory; and yet these charming works prove 


\section{FRENCH POTTERY \& PORCELAIN}

$\checkmark$ the inability of Sèvres to make statuettes covered with a fine enamel like those of Saxony. The first statuettes were executed after pastorals by Boucher-charming, delicate pieces of work typifying all the wit, grace and elegance of that fascinating century. Great sculptors were the authors of these productions, and in the first rank of their names shine those of Clodion, Pigalle, and Houdon. The manufacture of biscuit-porcelain statuettes in soft paste was almost entirely given up after I777; and this is to be deplored, as if the soft paste has drawbacks for objects of utility it is none the less greatly superior to hard paste from the decorative point of view.

Finally, Sèvres has executed a certain number of pictures; and I hasten to say that it is here I see most weakness. Why? Because every material ought to be treated with regard to its own individual character; and when marqueterie, ceramic, and needlework aim at the same end as painting they ignore this incontestable truth, which is one of the essential principles of all the arts. Certainly Iadmit that marqueterie and ceramic -as I have cited those two examples-move I I 4 


\section{SĖVRES}

in parallel lines with painting, and represent similar visions; for such visions may undergo the necessary modifications for each particular technique. But that they should imitate painting in a textual manner is an absolute and irredeemable error; for either the painting is bad and the ceramic good, or vice versâ.

This truth, although so elementary and obvious, has been ignored by some great artists-Ingres at their head, when he urged that the manufactory should reproduce works by old masters, and also by some modern painters. Happily, after a certain number of such reproductions (among which the most successful are the Raphael Madonnas, Baron Gérard's Psyche, Girodet's Atala, and Van Dyck's portrait), the manufactory, since 1878 , has abandoned this line of work. The last example was a copy of the Depart pour Cythere, by Schilt, which belongs to the Museum of the Hermitage at St. Petersburg.

The manufactory is right to devote its efforts to lines of work more in harmony with the means at its disposal-biscuit-porcelain, for example; and when we see to-day some of these charming statuettes signed by the 


\section{FRENCH POTTERY \& PORCELAIN}

best among the contemporary sculptors of France-above all by the great Rodin himself -we may reflect with satisfaction that, apart from some passing errors, Sèvres, without being absolutely on the level of the brilliant periods of Louis XV. and Louis XVI., is nevertheless still worthy of them in many respects.

From 1792 to 1800 the date-mark is wanting. The interlaced initials R.F., with the word Sèvres written in full, or else the same letters in juxtaposition and always above the word Sevres, are used up to I 799. Towards the end of that year the Republican monogram disappears; the name of Sèvres, written with the brush, appearing alone. In I8oI $\mathrm{T}_{9}$ is used; in $1802, \mathrm{X}$; in $1803, \mathrm{II}$.

About this time, and during the Consular period, an open vignette bore in red

$$
\begin{aligned}
& \S \text { M. N } \\
& \S \text { Sèvres }
\end{aligned}
$$

with different little signs above for I804, I805, and I806. At the beginning of the Empire this became

$$
\begin{aligned}
& \text { \. Imple } \\
& \S \text { de Sèvres }
\end{aligned}
$$

From I8 Io until the abdication the spread I 6 


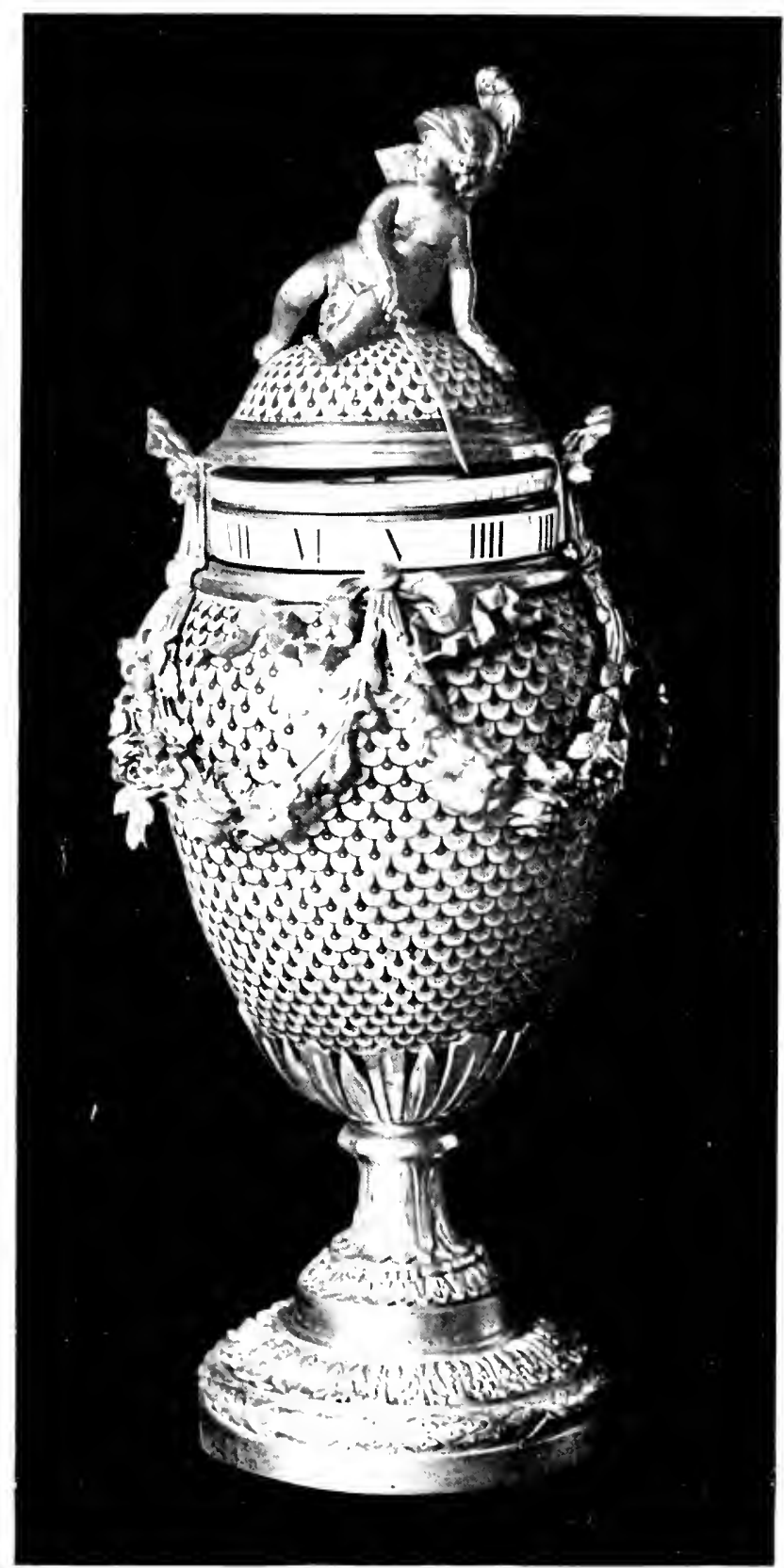

H. 17!" I', bast, 5:

CLOCK, sivres, Louis XV. South Kensington Musenus. 



\section{SĖVRES}

eagle replaces this inscription, and the year is indicated by a single figure: 1807 by 7 , 1808 by 8 , and so on.

In I8I i the system of letters was begun: oz for II, $d z$ for $I 2, t z$ for I3. Charles $X$. (I824-I827) had the mark of two Cs crossed with an $\mathrm{X}$ in the middle and a fleur-de-lys underneath, and from 1827 to 1830 the fleurde-lys took the place of the letter.

Louis-Philippe from 1830 to 1834 adopted a stamp with a circle enclosing a star, the word Sèvres, and the date figure; from 1834 to 1848 the monogram L.P.

In the second Republican period we find the letters R.F. in a double circle; under Napoleon III. the spread eagle or the $\mathrm{N}$ surmounted by the imperial crown in colours; and under the Third Republic the word Sèvres or a mark which will be found further on.

With our marks and monograms further on we shall give those of the Sèvres porcelain. But it is necessary to subjoin a few explanations. First of all, every artist from I 753 up to the present day had a special mark of his own; but it seems to me that it would be a risk to cause complication in the minds of those-collectors or inquirers-who may 


\section{FRENCH POTTERY \& PORCELAIN}

wish some day to refer to this book. Besides, the artist's mark is secondary, as the artists do not differ much in merit; what are important to know are the general marks of the manufactory, and the signs indicating the date-the essentially valuable thing for the collector.

During the time when the factory was at Vincennes the mark was two intertwined Ls, without any letter in the middle, or with a full stop. In I753 a chronographic letter became obligatory to indicate the year; it is placed usually in the centre of the monogram, or sometimes below, with the signs of the decorators lower still.

Here is a full list of the chronological marks since that date:

\begin{tabular}{|c|c|c|c|c|c|}
\hline Vincennes & A. & I 753 & Sèvres & N. & I766 \\
\hline$"$ & B & I754 & $"$ & O. & I767 \\
\hline & C. & I 755 & $"$ & P. & I768 \\
\hline Sèvres & D. & $175^{6}$ & $"$ & Q. & I769 \\
\hline$"$ & $\mathrm{E}$ & I 757 & $"$ & R. & I770 \\
\hline ", & $\mathrm{F}$ & I $75^{8}$ & $"$ & S. & $\mathrm{I} 77^{\mathrm{I}}$ \\
\hline " & G & I759 & $"$ & T. & $177^{2}$ \\
\hline ", & $\mathrm{H}$ & 1760 & $"$ & U. & $\mathrm{I} 773$ \\
\hline , & I & 1761 & $"$ & V. & I 774 \\
\hline ", & $\mathrm{J}$. & 1762 & $"$ & $\mathrm{X}$. & I 775 \\
\hline$"$ & K. & s 763 & $"$ & Y. & I 776 \\
\hline$"$ & L. & 1764 & " & $Z$. & I 777 \\
\hline " & M. & 1765 & " & A.A. & ${ }^{1} 77^{8}$ \\
\hline
\end{tabular}




\section{SÈVRES}

\begin{tabular}{|c|c|c|c|c|c|}
\hline Sèvres & B.B. & 1779 & Sèvres & I.I & I 786 \\
\hline 年 & C.C & 1780 & " & $\mathrm{J} . \mathrm{J}$ & 1787 \\
\hline " & D.D & I $78 \mathrm{I}$ & ", & K.K & I 788 \\
\hline$"$ & E.E & I782 & " & L.L & 1789 \\
\hline " & F.F & 1783 & ", & M.M & I 790 \\
\hline ", & G.G & 1784 & " & N.N & I $79^{I}$ \\
\hline , & H.H & 1785 & $"$ & 0.0 & I792 \\
\hline
\end{tabular}


THE TENTH CHAPTER

\section{VARIOUS MANUFACTORIES OF PORCELAIN}

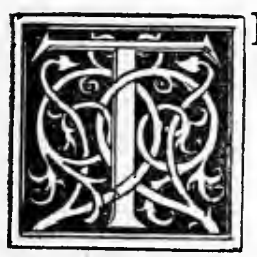

HANKS to royal favour and state patronage Sèvres enjoyed, we may say, a monopoly in porcelain-making; other manufactories played a less brilliant part in comparison, and produced far less work than did the faience manufactories, which were not so much hampered in their scope by anything in the shape of privilege. There were, nevertheless, other factories besides Sèvres whose products enjoyed well-deserved favour; Chantilly, Mennecy, and Saint-Cloud are also names dear to collectors, rivalling Meissen, Höchst, Vienna, and Berlin.

\section{Rouen}

We have seen that from the year 1673 Louis Poterat, of Rouen, was authorised by special privilege to manufacture porcelain; specimens of the productions of this period are extremely rare.

I 20 


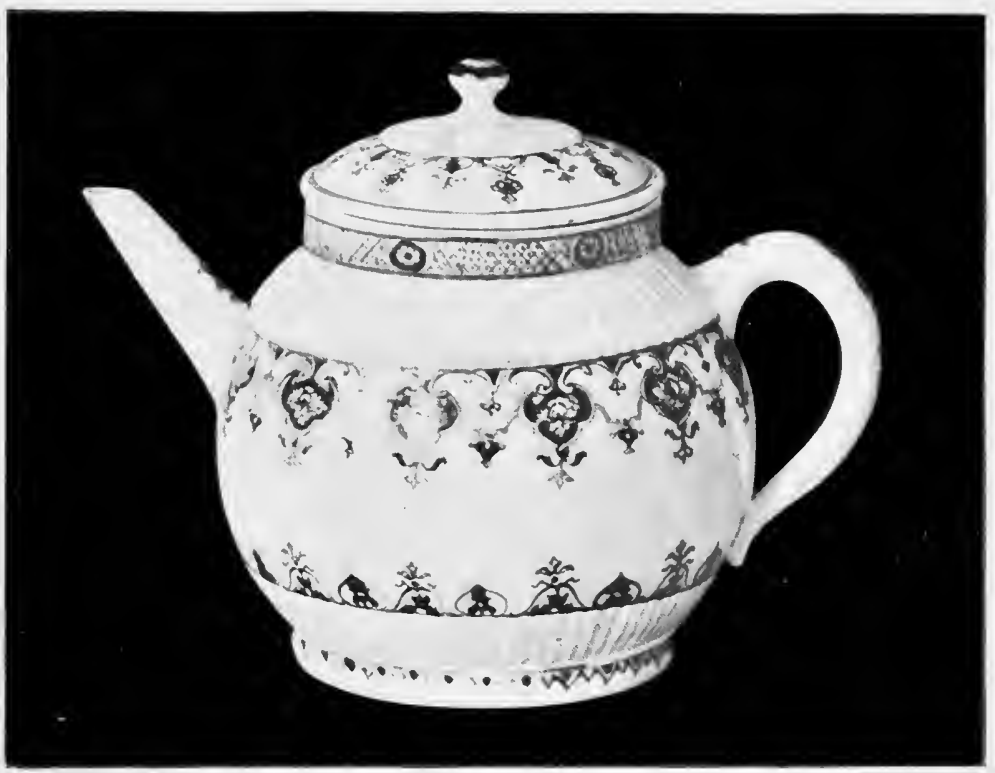

H. $4{\text { in W. } 65^{\prime \prime}}^{\prime \prime}$

TEAPOT, St. Cloud. South Kensington Museum. 




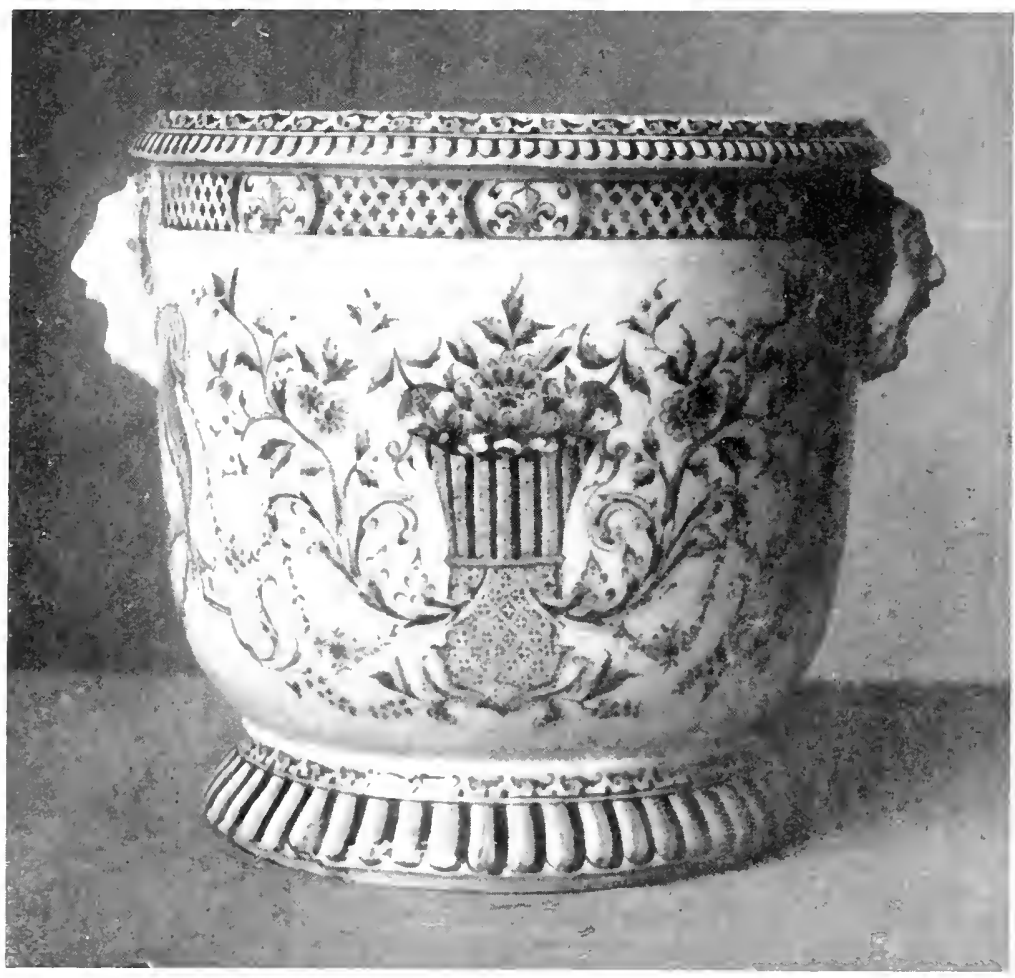

II. $9 !^{\prime \prime}$

[fhote, D. Frewler, Paris

SOFT PORCELAIN, of St. Clond before i joo. Sirres Museum. 


\section{MANUFACTORIES OF PORCELAIN}

\section{Saint-Cloud}

Some years later, in I695, the widow and children of Pierre Chicoineau, who were Saint-Cloud manufacturers, informed the king that they knew the secret of making true porcelain "of the same quality, and fit for the same uses, as porcelain from India and China." The king accorded them the privilege of manufacturing this porcelain, with the reservation of the rights given previously to Poterat. From this date onward the manufactory made soft porcelain, until its destruction by fire in 1773. This beautiful porcelain is decorated in blue with flowered scallops of lace-work in the Rouen style, and sometimes with subjects borrowed from the art of China and Japan. From I 702 to I 715 Saint-Cloud marked its pieces with a sun, the allusion being to Louis XIV. and his motto, Nec pluribus impar. Under the management of Trou, the successor of Chicoineau, the mark was a cypher consisting of the letter $T$ surmounted by the letters $\mathrm{S}^{\mathrm{t}} \mathrm{C}$. 


\section{FRENCH POTTERY \& PORCELAIN}

\section{LILLE}

The soft porcelain of Lille closely resembles that of Saint-Cloud, at any rate under the management of Dorez and Pélissier. In I784 Leperre Durot made hard porcelain, using coal. Thanks to $\mathrm{M}$. de Calonne this manufacture was placed under the patronage of the Dauphin, whence the mark and the name of Dauphin were given to it. This little-known porcelain is ornamented with rich gilding and delicate painting.

\section{Chantilly}

This is one of the great factories of France, and was founded by Cirou in 1725 under the protection of the Prince de Condé; it borrowed grotesque types from the East, delicate reliefs from Saxony, and graceful painted designs from Sèvres. Among its best artists may be mentioned Antheaume, Batuex, Cécier, Cornaille, and the modeller Bulidon, all of whom afterwards went to Sèvres. The paste was at first coated with an opaque enamel, replaced later by a vitreous glaze. The mark is a huntsman's horn, carefully painted in red.

\section{22}




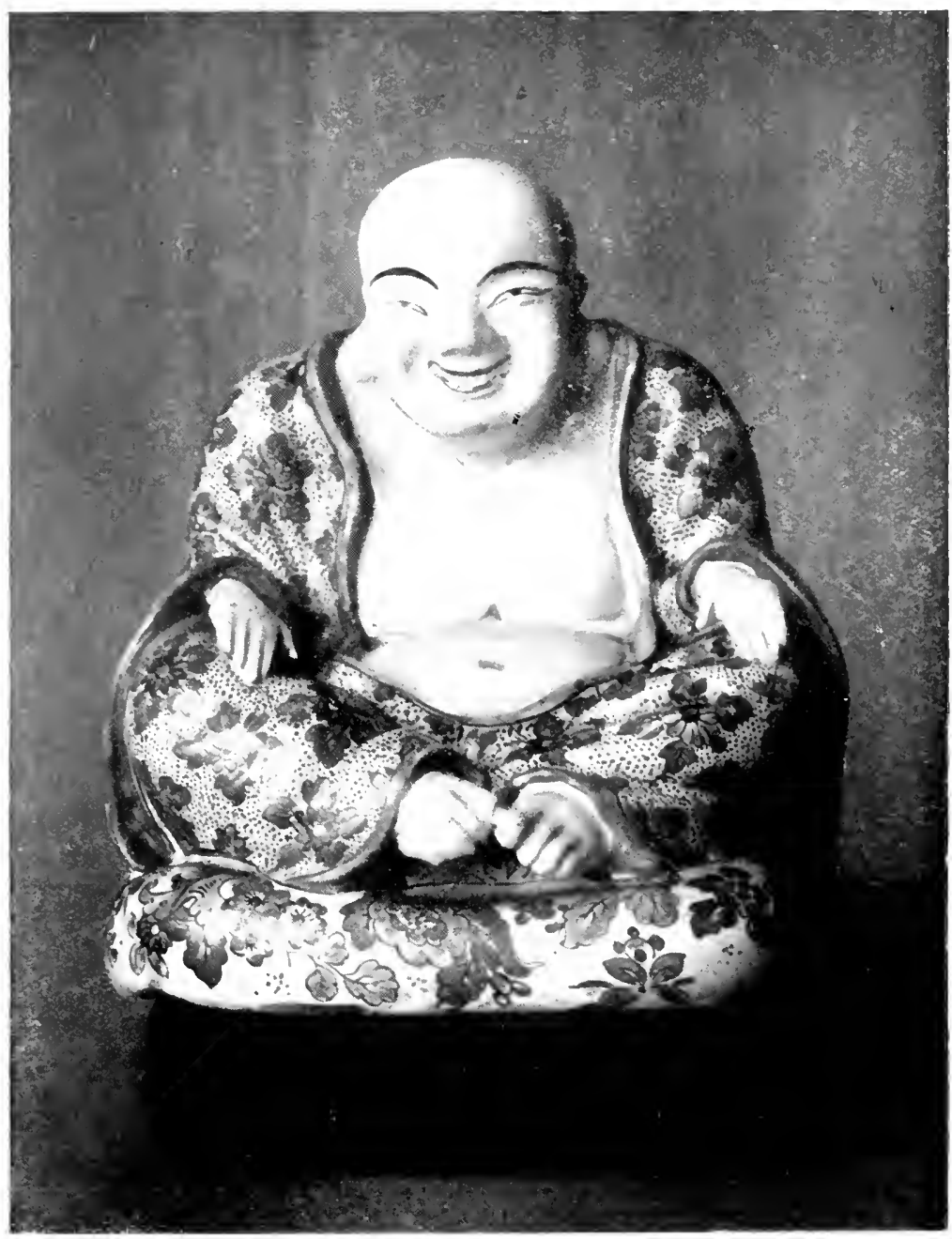

11. 5!"

[Phoo, I) Freuler, Paris

FIGURE, of Soft Porcelain, Chantilly. Alout 1735.

Sèvres Museum. 



\section{MANUFACTORIES OF PORCELAIN}

\section{MenneCy}

like Chantilly, made soft porcelain, and with very great success. Marshal the Duc de Villeroy founded the factory on one of his estates. Chantilly productions are much sought after: vases whose lids are ornamented with finelymodelled flowers and fruits; groups of elegant little figures in biscuit-porcelain; shepherds and shepherdesses; and ornamental vases-all worthy of Sèvres itself. Barbin was the first manager; the business was liquidated in 1766 ; and in 1773 its managers, Jacques and Jullien, went and settled at Bourg-la-Reine.

\section{PARIS}

During the eighteenth century the capital possessed a large number of factories, patronised by the princes of the royal house. Thus in $I 769$ hard porcelain was made at a factory directed by P. A. Hannong of Strasburg; but at the outset this factory did little work, and never became really prosperous till after it had obtained the title of the Comte d'Artois's factory. Its favourite ornament was bunches of flowers in polychrome and in 


\section{FRENCH POTTERY \& PORCELAIN}

wine-reds. The two factories of the Rue de la Roquette (Souboux, and afterwards Ollivier in the one; and Dubois in the other, called the Mamifacture des Trois-Levrettes) date from somewhere about I774. At the same time was founded the famous factory of La Courtille, managed by Locrée, and also called Mamufacture des Deux Flambeaux, because its mark slightly resembled that of Saxony. The factory of Clignancourt was patronised by the Comte de Provence, the same who encouraged the potters of Marseilles. In the Rue Thiroux, about I778, André Marie Le Bouf, under the protection of Marie Antoinette, made the celebrated porcelaine $\dot{a}$ la Reine, which is so carefully painted and executed that it might well have come from Sèvres. Two years later, Gerhard and Dihl founded the factory of the Duc d'Angoulème. Dihl did such remarkable work that the princes bought from him many of the rich presents which they were obliged to make: vases painted by Leguey; biscuit-porcelain of all kinds; plates with paintings of flowers and fruits; or landscapes from the brush of Drolling, Duchesne, or Demarne. In the Rue des Boulets there was established in I 24 


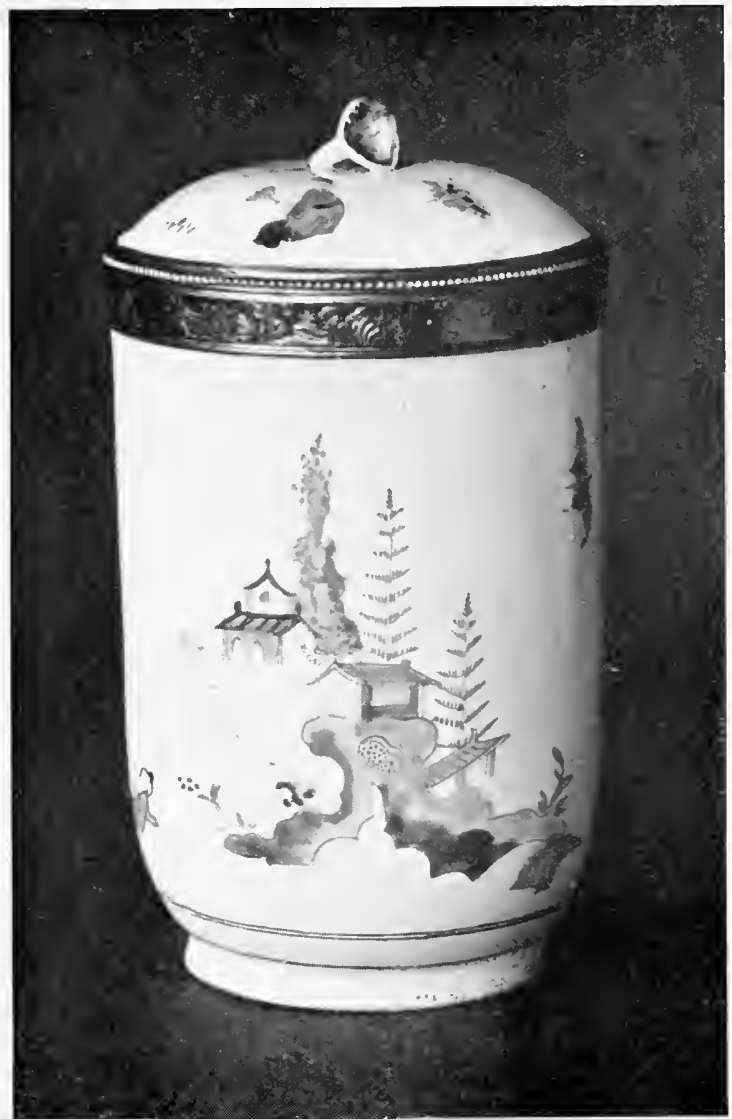

H. 7" D. 4 "

VASE WITH COVER, Chantilly. Collection of J. H. Fitzhenry, Esq. 



\section{MANUFACTORIES OF PORCELAIN}

I 784 a manufactory of hard porcelain, patronised by the Duc d'Orléans; and five years later the Englishman, Potter, established a factory called after the Prince of Wales, which executed some charming work decorated with butterflies, flowers, and beautifully painted ornaments. The pieces are signed Potter, in full.

The environs of Paris were no less enterprising than the capital itself.

\section{VINCENNES}

This was the royal factory before that of Sèvres, and the history of the two is confounded to a certain extent. Vincennes executed charming groups in soft porcelain, like those in the Sèvres Museum, but its specialty was chiefly flowers.

These flowers were manufactured in enormous quantities; they were intended for mounting on branches made in bronze, and were often used to accompany Meissen figures brought for the purpose, or even Chinese curios, also in porcelain. Nearly all the old porcelain mounted at this period, even that of Meissen, has flowers made in France. 


\section{FRENCH POTTERY \& PORCELAIN}

These flowers were collected into bouquets, placed in vases and adorned with bronze and other accessories in porcelain.

This manufacture had one advantage, viz., that it was possible to employ a richer and more intense scale of colouring on the soft porcelain than could be used upon hard porcelain, and consequently upon that of Meissen; greater fidelity to nature was therefore attainable, and in this particular pride was evidently taken. It is related that Mme. de Pompadour, the enthusiastic patroness of this factory, one day showed Louis XV. some flowers of this sort in her hot-house; the king imagined them to be natural, and the mistake caused him to take great delight in the products of the manufactory.

\section{Sceaux}

made not only faience but also exquisite porcelain, decorated with flowers, still-life, and groups of little cupids in the clouds. The factory of Etiolles also, in the neighbourhood of Paris, must not be forgotten; it was managed by Monnier about 1768 . 


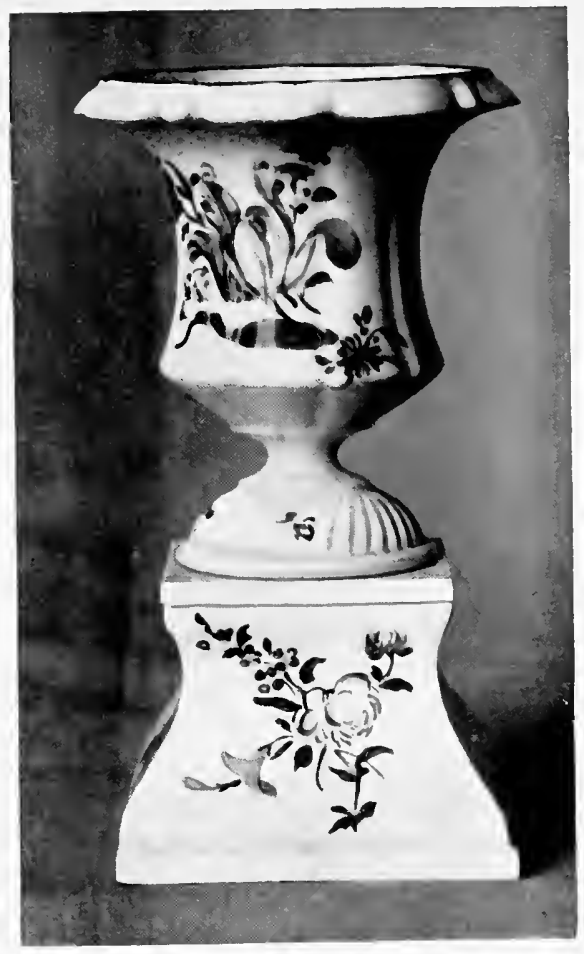

H. 6" Photo, D. Frouler Paris

VASE, of soft porcelain. Menney-

Villeroy. I 7 So. Sèvres Museum. 



\section{ORLEANS}

Pierrot, a master glass-maker, made an imitation of porcelain in glass and enamel, from I686 onwards. In 1757 Gérault-Baraubeart bought a faience factory, and made both hard and soft porcelain. Nevertheless the productions of Orleans are rare. From 1808 to I8I I the factory was managed by Lebrun.

\section{StRASBurG}

The lovely porcelain made by Hannong, which has already been mentioned, shows characteristics similar to those of the Strasburg faience. A similar remark may be made as to the porcelain of Marseilles, of Niederwiller, and of Moustiers.

\section{LIMOGES}

Messié obtained permission in $\mathrm{I} 773$ to establish a porcelain-factory in partnership with the brothers Grellat and Fourneira. Despite the beauty of their achievements the financial results were bad, and in 1784 the king acquired the factory for the sum of 


\section{FRENCH POTTERY \& PORCELAIN}

33,000 livres. During the Revolution it was again sold by two workmen who did not know how to make it pay. In 1794 the factory of Minnerie was founded at Limoges; in 1797 that of Bagnol; in 1798 that of Allnaud.

\section{BORDEAUX}

There are hardly any documents relating to this porcelain. According to Jacquemart, Verneuille made fairly good porcelain about I 770 .

\section{Arras}

The history of Arras porcelain is also very obscure. The best known maker is Deleneur.

\section{VALENCIENNES}

This establishment was founded in 1785 by Fauquez, who took into partnership first Vannier and afterwards Lamoninary. The produce of this factory may be traced to three principal sources: Sèvres, Saxony, and Niederwiller. Valenciennes produced charming work decorated with flowers, either strewn over the surface or arranged in garlands. I 28 


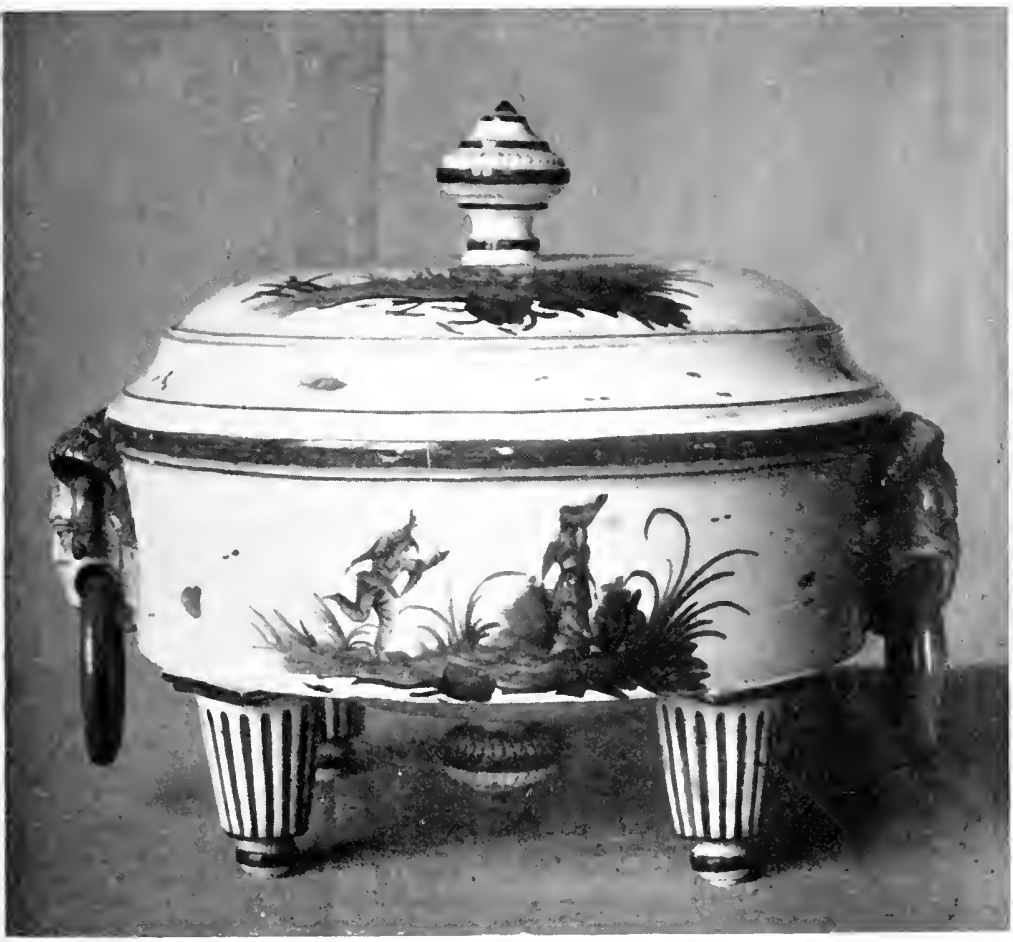

H. 8" [Photo, D. Freuler, P'aris HARD PORCELAIN, of Strasbourg (about 1770). Sives Museum. 



\section{MANUFACTORIES OF PORCELAIN}

The paintings are often in medallions, and owe their origin to Joseph Fernig. The historians of Valenciennes give also a list of thirty-two subjects executed in biscuit-porcelain, no doubt by Fickaert and Renaud. 
THE ELEVENTH CHAPTER

\section{LIST OF PIECES OF FRENCH FAIENCE \& PORCELAIN SOLD SINCE I882}

\section{882}

Benjamin Fillon's Collection

$$
\text { March 20, I882 }
$$

Palissy . Fine oval dish in faience by Bernard Palissy . . . . . . 1000

Rouen . Large round dish in old Rouen faience 5 ro

Rouen . Pretty sugar-basin, vase-shaped, same manufactory . . . . . 300

Sèvres . Busts of Marat in Sèvres biscuitporcelain, attributed to Beauvallet . $6_{50}$

Paris - Busts of Napoleon Bonaparte and Hoche, biscuit-porcelain, by $C^{u}$ Nast, Rue des Amandiers, Paris . . 460

Collection of A. Febvre, Sen., Expert April I7, I882

Sèvres . Fine circular covered écuelle, with oval tray in soft porcelain, old Sèvres, temp. Louis XV. . . . . $\mathrm{I} 420$

Sèvres . Stand of a jardinière, same manufacture, mounted as inkstand . . 600 


\section{PIECES SOLD SINCE 1882}

I 883

\section{Beurdfiley Père Collection}

$$
\text { April 23, I } 883
$$

Sèvres . Fine Sèvres vase, oval in shape, body plain and neck fluted, decorated with medallions . . . . I7,000

Sèvres . Two other fine vases of cylindrical form, same manufacture . . . .10,000

Sèvres - Large and fine vase, ovoid in form, same manufacture . . . . 8000 Sèvres . Two statuettes "Garde à Vous," old Sèvres biscuit-porcelain . . . roro Nevers - Circular dish in old Nevers faience, "Adoration of the Magi" . . 700

$$
\text { I } 884
$$

Ribeiro Da Cunha Collection of Lisbon

$$
\text { April I7, I884 }
$$

Sèvres - Coffee-service (4 cups and saucers, I sugar-basin, I milk-jug), royal-blue ground. Date 1777 . . . 2000

Milet Collection of the Sévres Manufactory

$$
\text { March 3, } 1884
$$

Rouen . Very fine castor for powdered sugar, decoration embossed on yellowbrown. Old Rouen of best period. 3500 


\section{FRENCH POTTERY \& PORCELAIN}

Rouen . Large cylindro-conical vase, blue decorations, attributed Poterat, Rouen, seventeenth century . . 445

Sèvres . Two vases, either for pots or winecoolers, manufactured by Tron at Saint Cloud . . . . . 340

FRANCS

\section{Fountaine Collection}

Oiron faience

Oiron

faience Oiron faience

Mortar for wax

Candlestick with Montmorency arms • 9I,875 Biberon $\cdot 26,5^{\mathrm{I}} 3$

\section{BARON L. D'IVRY'S COLLECTION}

$$
\text { May 7, } 1884
$$

Sèvres - Fine watering-pot in the form of an upright barrel, Sèvres (letter B, I754) I500

Sèvres . Fine tea-service (tray, sugar-basin, cream-jug, two cups and saucers; Sèvres (letters A A, I777). . . 2050

Sèvres - Pair of charming little vases, Sèvres (letter H, I760) . . . . 2250

Sèvres - Cup and saucer, rose du Barry ground, Sèvres . . . . $\quad$ I300

Chantilly. Two vases for pots, fluted, with perforated borders

St. Cloud Small funnel-shaped vase with wide mouth, St. Cloud . . . 430 


\title{
PIECES SOLD SINCE I882
}

The MARQuis of OSMOND'S COLlection

February 9, r884

Sèvres . Pair of very fine oviform vases, decorated on a sea-green ground. Remarkable Sèvres pieces, temp. Louis XV. . . . . . 86,100

Sèvres . Very fine Sèvres vase, same shape and same decoration . . . . . 51,000

Sèvres . Pair of very fine vases, body cylindrical in form, dark-blue ground powdered with gold (rare form), Sèvres, Louis XVI.

. 65,000

Sèvres . Very fine jardinière, so-called fanshape, rose Du Barry ground, Sèvres (date I757), decorated by Grison

Sèvres . Two other fine jardinières of same shape and make, royal-blue ground, decorated by Tandart . . . I6,100

Sèvres . Deep cup, decangular in form, green ground, Sèvres ( 1782 ), decorated by Aubert and Prévost . . . $295^{\circ}$

Sèvres . Fine chocolate-pot, dark-blue ground, Sèvres (I764), decorated by Vieillard 3700

\author{
I 885 \\ Collection of Fournier Pére \\ March 2, I885
}

Sèvres . Pot-pourri jar, oviform body, with pedestal and cover . . . . . I2,200 


\section{FRENCH POTTERY \& PORCELAIN}

Sèvres . Two small jardinières, pedestal-shape ( $\left.175^{6}\right)$, decorated by Vieillard . . 8000

Sèvres . Pair of four-sided baskets (I756) • 4000

Sèvres . Tête-à-tête set (two cups, teapot, and sugar-basin), I783, decorated by Prévost . . . . . . I680

Sèvres . Pair of candlesticks, decorated by

Pierre Le Jeune . . . . 2300

Sèvres - Large cup, shape of inverted cone

(I756), decorated by Mérault ainé - 3250

Sèvres- Large oviform vase, dark-blue ground,

Vincennes striped with gold . . . . 4000

Sèvres . Rectangular plaque, with gilt border in relief framing a landscape with figures, decorated by Boucher and Baudouin . . . . . 1265

La Beraudiḱre Collection

$$
\text { May I8, I } 885
$$

Rouen . Pichet, polychromatic decoration, bearing name of Marie-Louise Nivard, I75I . . . . . 300

Sèvres . Fine vase, flattened baluster-shape . 7000

Delaherche Collection of Beauvais

$$
\text { March I8, I885 }
$$

Lille . Plate, polychromatic decoration . 600

Lille . Plate, blue decoration . . 370

Rouen . Cider-jug bearing name of François Séjourné . . . . $\quad 265$ 


\section{PIECES SOLD SINCE I882}

Rouen . Dish with arms of Mme. de Lorges. 680

Sinceny. Pichet upon which are represented the equestrian portrait of the Seigneur de Sinceny, the keep of the castle, coats-of-arms, and instruments of music and of war . . I020

\section{Watelin Collection}

May 5,1885

Moustiers. Oblong épergne, "Apollo drawn by Dragons," with coats-of-arms and ducal crown (Richelieu-Guise) . 524

\section{Dupont-Auberville Collection}

\section{March I6, r885}

Chantilly . Pair of perfume-jars called pots-pourri 2060 Chantilly. Group composed of one seated figure and a child standing . . . 900

Chantilly. Figure representing “A Marketporter" . . . . . . 400

Chantilly. Two plates with lobed and gilded borders. Mark, a hunting-horn with an $\mathrm{R}$ in blue and a B in gold . . 660

Mennecy . Two figurines, male and female monkeys, in Louis XV. costumes . . 6 $\mathbf{I}_{5}$

Mennecy. Two figurines upon a stand, shepherd and shepherdess, in Louis $\mathrm{XV}$. costumes . . . . 820

Mennecy. Vase for flowers . . . . . 500 Mennecy. Figurine. A female pedlar (earliest period) . $\quad . \quad . \quad . \quad . \quad .270$ 


\section{FRENCH POTTERY \& PORCELAIN}

Nevers . Pilgrim's-bottle in polychrome (earliest period) . . . . . . 240

Nevers . Very fine dish, representing horsemen starting for the chase (period termed "des Conrad") . . .

VALUABLE SPECIMENS FROM THE WORKSHOPS

OF POTERAT, INVENTOR OF ROUENNESE

SOFT PORCELAIN

Rouen . Sugar-basin, conical in form . . 205

Rouen . Goblet-cup with scallops and the mark of Poterat . . . . I60

Rouen . Housewife in a spice-box (Poterat) . 300

Rouen . Salt-cellar raised upon a stand (Poterat) • . . . . . $\mathrm{I}_{5}$

Rouen . Large pichet decorated in blue, "Adam and Eve," with date I688 . . 200

Rouen . Sugar-basin, decorated in yellow-ochre 4 I0

\section{886}

\section{MaZe-Sencier Collection}

(Author of Recherches sur la Ceramique and of the Livre des Collectionnesrs)

\section{March I9, 1886}

Aprey . Lobed and embossed plate, decorated by Jarry . . . . . . II5

Aprey . Oblong dish with scalloped edge, decorated by Jarry • • • • $\quad$ I 35

Bellevue . Busts of Voltaire and Rousseau . . I20

Clermont- Two plates with coats-of-arms and a

Ferrand Baron's coronet . . . . I82

Moustiers Plate with subject "St. Michael overcoming the Dragon" . . . 900 


\section{PIECES SOLD SINCE I882}

Nevers . Pair of large octagonal cornucopias, Dutch-Japanese . . . . 620

Nevers . Potiche with Persian blue ground, birds, flowers, and foliage . 200

Nieder- Two square trays, decorated with willer . bouquets of flowers . . . 230

Pré d'Auge Flat hunting flask, sixteentl century . 205

Rennes . Barber's dish, style rocaille, barber's shop with a Figaro bleeding a patient 2 Io

Rouen . Large circular dish, manufactured by Louis Poterat . . . . 400

Rouen . Large circular dish with arms of Jacques Arrelin, Sieur de Villequies, who died in 1728 . $\quad . \quad . \quad .590$

Rouen . Plate with striped blue decoration and arms, by Louis Poterat . . . II5

Rouen . Octagonal oblong dish, superb striped decoration . . . . . 1020

Rouen . Soup-tureen lid with arms of the Duc de Montmorency-Luxembourg • 500

Rouen . Plate with yellow-ochre ground, "Cupids dancing," time of the Regency . . . . . 2570

Sceaux . Semi-circular jardinières, hunting-subjects on medallions, Dehueux decoration in polychrome. . . 800

\section{De Lafaulotte Collection}

\section{April 7, 1886}

Sèvres- Two wide-necked and lobed vases, Vincennes Louis XV. period . . . . 5200 


\section{FRENCH POTTERY \& PORCELAIN}

Sèvres . Two fan-shaped jardinières, letter B, I 754

Sèvres . Circular écuelle with two interwoven handles, L. A. I753, mark of Ledoux

Sèvres . Statuette of standing fardinière,dressed in rose-colour. . . . . 1000

Sèvres . Chalice for fruits with monogram of Du Barry . . . . . 6ro

Sèvres . Two wide chalices in hard paste . 4000

Chantilly. Crouching Chinaman, decoration in polychrome . . . . . 9 Io

Chantilly. Two small buckets (seaux) decorated with shrubs and flowers . . . 580

Mennecy. Two small baluster-shaped vases with handles . . . . . 520

Moustiers Very large circular dish with blue decorations and Chinese figures .

Nevers . Two cylindrical vases, decoration in Italian style $. \quad . \quad . \quad . \quad .5$ ro

Nevers . Two round-bodied vases, balustershaped, Chinese style • • . 430

Nevers . Eared pilgrim's-bottle with grimacing masks, blue decoration, Chinese style

Nieder- Small plate with scalloped edges, dewiller . coration in polychrome. . .

Palissy (B) Circular dish executed on one of the tin models by François Briot; allegorical figures, "Temperance, the Sciences, and the Arts" (At Baron Seillière's sale in 1890 this same dish fetched 12,500 francs) • . 25,700

Palissy (B) Body of flagon, allegorical figures, "Earth" and "Water" . . 4500 


\section{PIECES SOLD SINCE I882}

\section{I887}

Collection of M. Frédéric Fetis, of Brussels

$$
\text { April 18, т887 }
$$

Nevers . Large dish, Persian blue ground, birds, branches, and flowers . . 2400

Rouen - Large dish, richly (Both bought by) decorated in blue the South $\quad$ I $5^{\circ}$

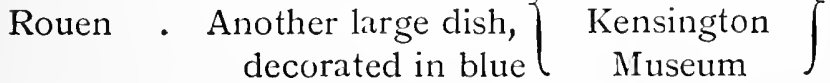

Lille . Plate, two Cupids supporting a scroll, on which is written: "Maitre Daligné"; on the back a rocaille medallion surmounted by a royal crown, with "Lille, 1767 " . . . . . 775

St. Amand Plate with medallion, seated figure in Watteau style. On the back, Fauquet's monogram . . . . 2 Io

Sceaux . Two plates in the Marseilles style, landscapes with figures (Glot period) 300

Sceaux . Water-jug and basin marked O.P., and lower A. Pinxite

Luneville Large group in polychromatic faience, "Bélisaire Begging," by Cyffé . 2 so

Moustiers Large oval dish, blue decoration in 850 the Bérain style (Acquired by South Kensington Museum, having been sold for $\mathrm{I}$ I60 frs. in a sale of March 21, 1873) . . . . 1020 


\section{FRENCH POTTERY \& PORCELAIN}

\section{888}

\section{S. Goldschmidt's Collection}

$$
\text { May I7, I } 888
$$

Palissy (B) Oval dish, subject: "La belle far-

\section{DR. RAYMOND'S COLlection}

November I4, I 888

Nevers . Two small vases with panels, first period

Nevers . Pilgrim's-bottle, flattened pear-shape, flowers and birds on Persian bluc ground

Rouen. Two large and magnificent rectangular trays: one represents Vulcan surrounded by divinities; the other, the triumph of Juno (They had been sold to a merchant for 16,000 frs.) · . $\cdot$. $\cdot$

Moustiers . Large oval dish, blue decoration, "Tiger Hunt"

Limoges . Large wall-fountain, blue decoration, figure in Chinese style. On the interior is to be read: "Limoges, I739" (Limoges Museum) . .

Lille . Plate decorated in blue, Rouennese style, two children dancing, medallion with initials of Feburier de Lille. (Acquired by the Limoges Museum) . 


\section{PIECES SOLD SINCE 1882}

\section{889}

MARQUis D'IQUELON'S COLLECTION

April 8, I889

Rouen . Fine rectangular tray, richly decorated on yellow-ochre ground, group of seven children and two dogs . . 7023

Rouen . Fine deep circular dish, yellow-ochre ground, group of four children $\quad 235^{\circ}$

I 890

\section{Secretan Collection}

$$
\text { July } 4,1890
$$

Sèvres . Very fine vase, turquoise blue ground, medallions with Cupids and flowers 20, 100

Sèvres . Fine vase, oviform body, apple-green ground, enriched with four medallions . 19,000

Baron Seilitère's Collection

$$
\text { May 5, I890 }
$$

Palissy . Fine circular cup upon pedestal, with interlaced monograms of Henri II., Catherine de Medici, and Diane de Poitiers; the concave portion enamelled green (This came from the Préaux Collection in 1850 , when it fetched 1500 frs., and in 


\section{FRENCH POTTERY \& PORCELAIN}

the Rattier Collection in I859 it fetched 6500 frs.) . . . . II,500

Palissy . A cup exactly similar to the foregoing, the concave portion in marbled enamel (In the Préaux Collection in $185^{\circ}$ fetched 1600 frs., and in the Rattier Collection, I859, 6000 frs.) · I I,500

Palissy . Large oval dish "La Fécondite" (Was bought for Io80 frs. at the Soltykoff Sale in $\mathrm{r} 86 \mathrm{r}$ ) . $\quad . \quad$. $\quad .4000$

Palissy - Large fine dish, deep and circular: Perseus freeing Andromeda . . 2500

Strasburg Clock of twisted shape tipon consolepedestal; motifs in rocaille and coloured flowers, with female heads enamelled in natural colours . . $265^{\circ}$

Sèvres . Small cylindrical cup, turquoise-blue ground; the saucer bears in its centre the monogram of Catherine the Great of Russia, formed of flowers, and the Imperial crown . I750

Chantilly. Two cylindrical pots, with dragonhandles . . . . . . 2500

I89I

Ploquin Collection (First Sale)

February 17, I 89 I

Nevers - Large fountain in the form of a vase, decorated in polychrome . 2500

Nevers . Plate, blue border, and decoration in full polychrome . . . . 660 


\section{PIECES SOLD SINCE I882}

Rouen . Pair of pilgrim-bottles, flattened oviform, decoration pseudo-Chinese . I650

Rouen . Susgar-basin, baluster-shaped, richly decorated in blue and rust-colour.

Sinceny . Oviform pichet, decoration in polychrome, initials I. N. C., and date I 757 .

400

Sinceny . Large long-shaped dish with scalloped edges, decoration pseudo-Chinese . 400

Sceaux . Pair of jardinières, semi-circular in shape (No. 1738 in the Exhibition at the Trocadero) . . . . 2000

Sceaux . Pot-pourri jar, vase-shaped, decoration in polychrome. . . . . 1399

Marseilles Urn, Medici-shape, decoration in polychrome . . . . . . 485

Moustiers Water-jug with cover and oval basin ; subject, “The Judgment of Paris" . 755

\section{892 \\ D'Yvon Collection}

May 30,1892

St. Porchaire, Faience of, so-called "d'Oiron" or " de Henri II." Very fine salt-cellar, in the form of a little triangular temple (very rare specimen) . . .25,500

Palissy . Large oval dish : "La Charité" or " $L a$ Fécondité". . . . . 4600

Rouen . Large circular dish with basket of flowers in a medallion, marked G. Gillibaux . • . . • . 4020 


\section{FRENCH POTTERY \& PORCELAIN}

Sivres shape, decorated by Morin and Boulanger . . . . . 7000

I 893

SPITZER COLLECTION

April-May, I893

Palissy . "L'Ean," rectangular bas-relief (for the Louvre) . . . . . . .27,000

Palissy . Large circular dish (or stand) for aiguière, marine deities . . . . 10,000

Palissy . Large circular dish, "Diana" . . . . 10,800

Palissy . Large oval dish, "La Féconditē" . 2000

Palissy . Open-work chalice for fruits, marbled reverse . . . . . . 3100

Palissy . Aigutière in the shape of a helmet, "Pomona and a Spring" . . . 19,500

Palissy . Similar aiguière, but the ground enamelled brown . . . . . .19,500

Palissy . Large salt-cellar, "Neptune standing upon the Waves" . . . . 7000

St. Porchaire. Faience of, so-called d'Oiron or de Henri II. Salt-cellar of triangular form, with the monogram of Henri II. and Catherine de Medici . . 20,000

St. Porchaire. Hexagonal salt-cellar, with shield having the arms of France on the pilasters at the corners. . . II,000

St. Porchaire. Hexagonal salt-cellar, with three figures of children in the interior . 10,200

St. Porchaire. Cup, circular and flattened in shape 30,500 I 44 


\section{PIECES SOLD SINCE I882}

St. Porchaire. Triangular salt-cellar, monogram of

FRANCS

Henri II. and Catherine de Medici

9100

St. Porchaire. Aiguière, two flattened hemispheres on which are busts of men surrounded by foliage . $\quad . \quad \cdot \quad \cdot 32,000$

$$
\text { I } 895
$$

\section{Charles Antig Collection}

$$
\text { April 3, } 1895
$$

Nevers - (First Period) Small deep dish, decoration in polychrome

Nevers . (First Period) Plate in the style of the Urbino faience (the only known example of this). On the back: May r644.

Nevers . Large drug-vase, decoration on darkblue ground; from the Pharmacy of the Hospice de Moulins . . $235^{\circ}$

Rouen . Large dish, in the centre a medallion with black enamelling in the style of Boulle on a yellow-ochre ground . . . . . 2600 Acquired by M. Gérard, and at his sale in $1900 . \quad . \quad . \quad .3100$

Rouen . Plate with a border of arabesques and black chequering on a ground of yellow-ochre, Regency period

Rouen . Very large dish, richly decorated in blue. . . . . . . $165^{\circ}$

Rouen . Rectangular dish, "The Triumph of Amphitrite," decoration blue and red 


\section{FRENCH POTTERY \& PORCELAIN}

Sinceny . Covered piclict, decoration in rocaille and polychrome; subject, a young man surprising a woman bathing . I 180 (Was sold for 1200 francs at the Marquis sale, and I roo francs at the Gérard sale)

Moustiers Large oval dish, decoration blue, en camaieu, "Bear-hunt," signed G. Viry, made at Clérissy's, Moustiers. (Only one similar dish is known, and it is in the Museum of the Château Borély at Marseilles)

Marseilles Large covered wall-fountain and support, en rocaille, decoration in polychrome (mark of Veuve Perrin)

3000

FRANCS

3000

$165^{\circ}$

Marseilles Covered water-jug and basin with seagreen ground (mark of Veuve Perrin) 1960

Sceaux . Covered fan-shaped jardinière, decorated with a scene after Greuze . 6800

Paris (Digne). Wall-fountain, coat-of-arms of the D'Orléans family. Ordered from Digne by the Duchess Marie Adélaide, daughter of the Regent and Abbess of Chelles . . . 300

I 896

\section{Leroux Collection}

April I3, I896

Nevers . Two large aiguieres, "The Rape of Europa," and "Venus deprecating the wrath of Neptune" . . . $435^{\circ}$ 


\section{PIECES SOLD SINCE I882}

Nevers . Two large oviform aiguières, enamelled in dark-blue; foliage, birds, and butterflies . . . . . 3000

Nevers . Large dish, dark-blue ground, tulips, birds, and butterflies . . . 2500

Rouen - Watch-stand with dial upon a pedestal supported by two lions, orangeyellow ground . . . . .

Lorraine . (Enamelled earthenware of) Bust of

Louis XV. wearing armour and mantle, upon a square pedestal with shield supported by a lion (fetched I 20 frs. in I 898 at the Goldschmidt Sale)

\section{Ch. Stein's Collection}

$$
\text { June \&, I899 }
$$

St. Porchaire (or faience termed de Henri II. or d'Oiron) Aiglicre in the shape of a reversed cone, handle three times twisted round, the neck ornamented with a figure of the Virgin . . .49,000

St. Porchaire. Salt-cellar in the form of a hexagon . I9,000 Palissy . Large circular dish, "Diana Seated" (Had been sold for 10,800 frs. at the Spitzer Sale) . . . . I6, I00 


\section{FRENCH POTTERY \& PORCELAIN}

1900

Albert Gerard Collection

June 18,1900

Nevers - (First Period) Very large dish, "Perseus coming to deliver Andromeda." Italian tradition ( $\mathrm{Had}$ fetched 4000 frs. at the Du Sartet Sale, and 5800 frs. at the Fontain Sale)

FRANOS

Nevers . Very large dish, "A Roman Chariot."

A piece of the greatest rarity, considered unique, unfor tunately broken into five pieces

3600

Nevers . Potiche, balcony-shaped, decorated upon an orange-yellow ground, extremely rare piece (fetched I Ioo frs. at the Ploquin Sale) . . . 2600

Rouen . Sugar-basin, baluster-shape, decoration on yellow ground in black niello . . . . . . $435^{\circ}$

Rouen . Very large dish, centre medallion with yellow-ochre ground (fetched 2600 frs. at the Antiq Sale) . . . 3roo

Rouen . Plate decorated with arabesques, yellow ground; black niello . . 3500

Rouen . Plate, two Cupids en camaien in blue; same decoration and same ground (fetched $285^{\circ} \mathrm{frs}$. at the Waddington Sale). $\cdot$. $\quad . \quad \cdot \quad \cdot \quad 4300$

Rouen . Pair of flagons, richly decorated in blue and red, one marked G. S. 6300 


\section{PIECES SOLD SINCE I882}

Rouen . Four busts of figures typifying the

Seasons . . . . 5200

1902

Arnavon Collection of Marseilles

May 6, 1902

Moustiers Large bas-relief : bust of the Virgin . $\mathbf{I}_{55^{\circ}}$

Moustiers Large bas-relief: half-length of St.

Moustiers Oval basin: Cephalus and Aurora . I900

Moustiers Hunting dish: bear-hunting . . I 200

Moustiers Hunting dish : stag-hunting . . I050

Moustiers Hunting dish : bustard-hunting . . I250

Moustiers Hunting dish : bull-baiting . . II50

Moustiers Water-jug and basin:"Diana's Toilet" 3300

Moustiers Sugar-basin: Jupiter, Ceres, Diana, and Apollo . . . . . 2500

Marseilles Drug-vase : "Mithridates" . . . 730

Marseilles Statuette of lady in Louis XV. costume 535

Marseilles Water-jug and basin in the style of goldsmiths' work. Louis XV. decoration in polychrome, medallions en canaien after Fr. Boucher, monogram M.R.

Marseilles Winged écuelle and its tray, same 5500 decoration, and medallions en camaien sapphire-blue, monogram M.R.

3200

Marseilles Two urns or vases for pot-pourris, decoration in polychrome, landscape, marine view, and figures . 3600 


\section{FRENCH POTTERY \& PORCELAIN}

Marseilles Set of three baskets, openwork and en rocaille, scenes of gallantry . . 2000

1903

Madame Lelong's Collection

April 1903

Sèvres . Oval box decorated with roses and laurel wreaths . . . . . 4700

Sèvres . Two small square jardinières; little boys and girls, details of garden and pastoral scenes, I757 . . 20,000

Sèvres . Solitaire tea-set: tray, teapot, sugarbasin, milk-jug, cup and saucer; flowers and various details on china ground of blue and rose-colour, I76I-I762 . $\quad . \quad$. $\quad .28,000$

Sèvres . Two baluster-vases, white and gold decoration on turquoise-blue ground 25, 100

Sèvres - Two large groups in biscuit-porcelain :

Prometheus and Pygmalion . . 29,700

Sèvres . Two wine-coolers; Cupid in a landscape, and Allegory of the Arts, on turquoise-blue ground, I765, decoration by Dutanda . . . . 36,000

I904

Bourgeois Collection of Cologne

October 1904

Sèvres . Sauce-boat in porcelain (about I759), blue ground . . . . . 9ro 


\section{PIECES SOLD SINCE I882}

Sèvres Soup-tureen and tray

Sèvres . Deep plate . . . . . . 190

Chantilly Two small horn-shaped vases, soft

Palissy . Cup . . . . . . . 190

Palissy . Cup . . . . . . . 260

Moustiers Tray . . . . . . . 250

Rouen . Cistern for fountain (rocaille style) . $5^{\text {Io }}$

Rouen . Vase with cover (atelier Levavasseur). $\quad 230$

\section{Bellegarde of Rouen Collection}

December 1904

Rouen . Large dish, with eight Cupids upon blue camaicu . . . . . . 23,800

Rouen . Large tray, with allegorical subject in colours . . . . . . 5010

Rouen . Plate with musical inscription (rare specimen) . . . . . 4400

Rouen . Tray (Virgin and Child, on blue ground) . . . . . . 3100

Rouen . Jardinière (Levavasseur atelier) . . 2700

Rouen . Plate decorated with playing-cards . 855

Rouen . Plate decorated with cock-fight . . 800

Rouen . Plate, striped pattern . . . . I880

Rouen . Octagonal basin decorated in Chinese style . . . . . . . 250

Rouen . Basket, with scene of family life on bottom . . . . . 2500

Rouen . Baluster-shaped vase, chequered, and decorated with foliage . . .

Rouen . Chaise percée, decorated with flowers, \&c. . . . . . . . 2000 


\section{FRENCH POTTERY \& PORCELAIN}

Rouen . Two plates, Levavasseur atelier, decorated with views of sea-ports . I $35^{\circ}$

Rouen - Large dish, decorated with troop of six Chinese warriors . . $\quad 235^{\circ}$

Rouen . Large tray, decorated with chequers and rocaille . . . . . $\quad .930$

Rouen - Large tray, decorated in polychrome . 960

Rouen - Basket, with six Cupids upon a ground of yellow-ochre . . . . 1905

Rouen . Baluster-shaped sugar-castor . . 635

Rouen . Small bust of a king . . . . IOIO

Rouen . Two small shoes, decorated with flowers . . . . . . I200

Sceaux . Jardinière in faience . . . 2350

SALE of THE Baroness Dairllier

(Widow of the great writer and connoisseur)

December 1904

Nevers . Two vases in faience, with mythological subjects in blue . . $295^{\circ}$

Nevers . Large dish in faience, white decoration on blue ground . . . 800

Moustiers Large oval dish, blue decoration of hunting-scene . . . . 2000

Moustiers Large oval dish in faience, blue decoration . . . . . 800

Moustiers Ecuelle with cover, in faience . $\quad . \quad 835$ 
Plate lix

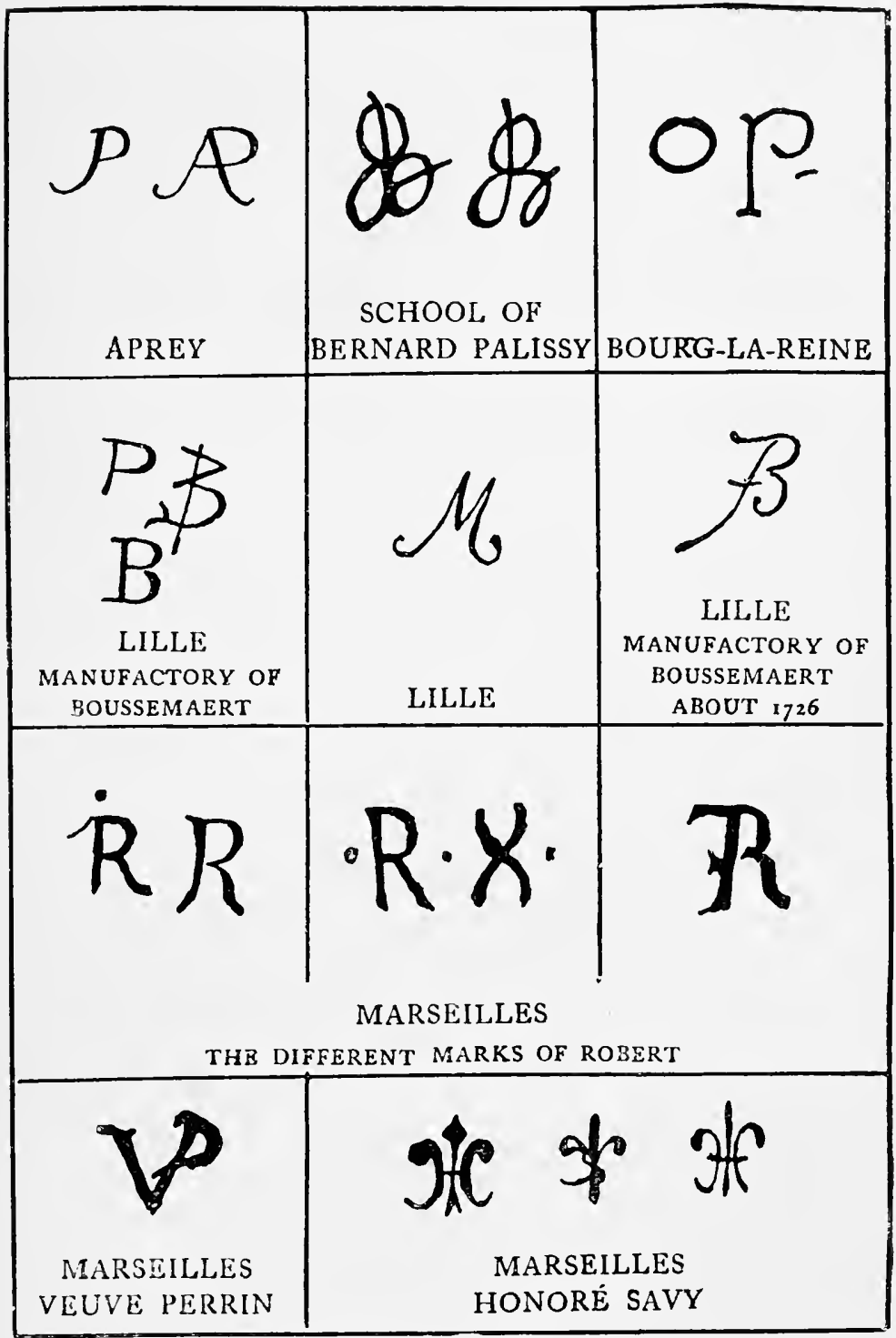

MARKS ON FAIENCE. 


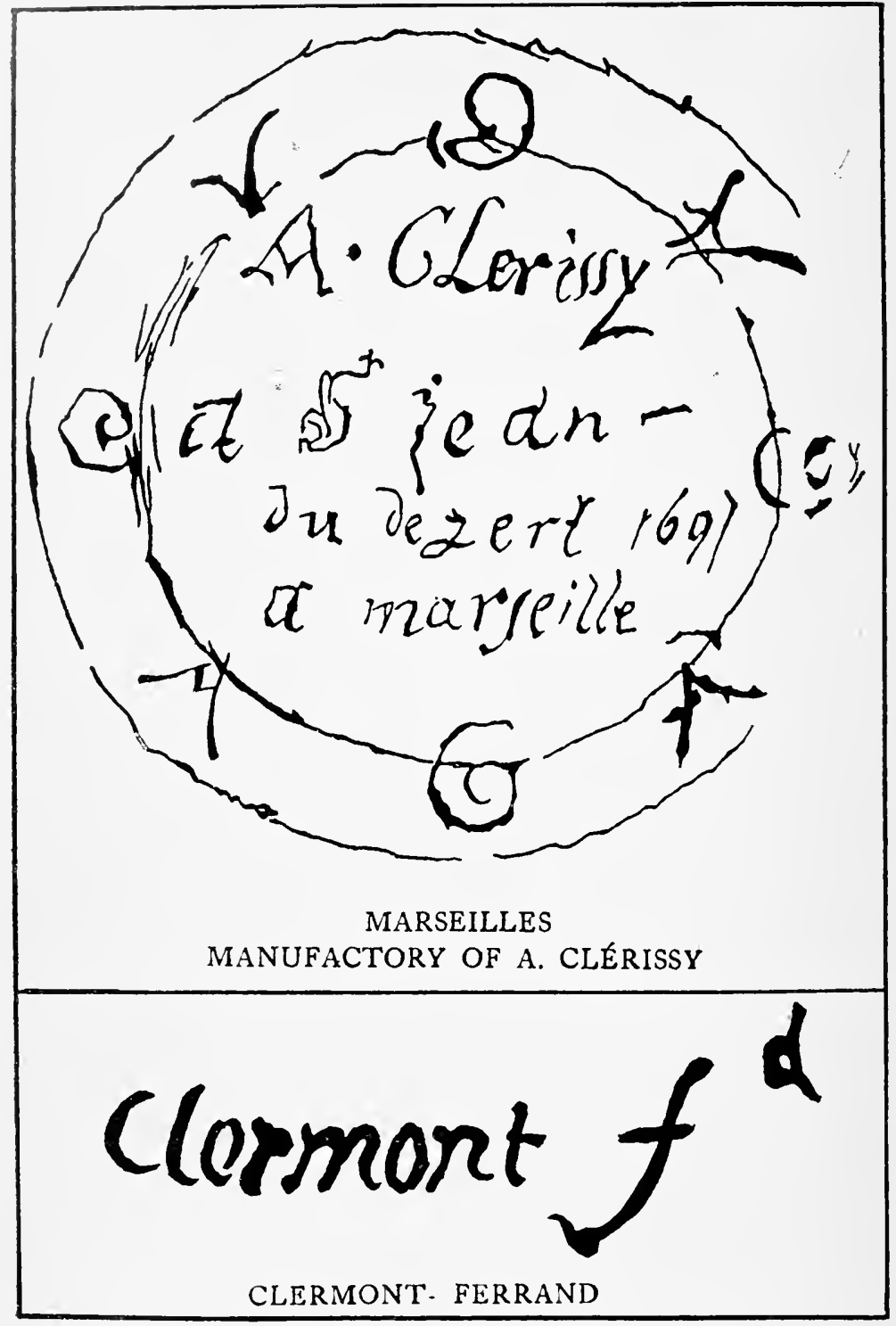

MARKS ON FAIENCE. 
S. uniff: a Moustiers chez cleriffy MOUSTIERS MANUFACTORY OF CLÉRISSY

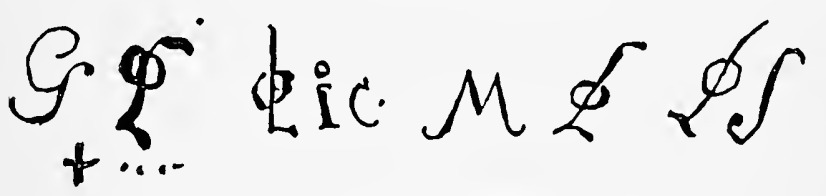

MOUSTIERS MANUFACTORY OF OLERYS

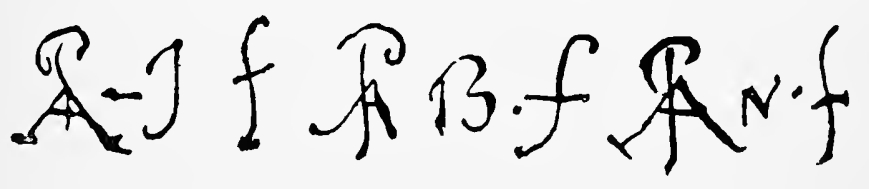

MOUSTIERS

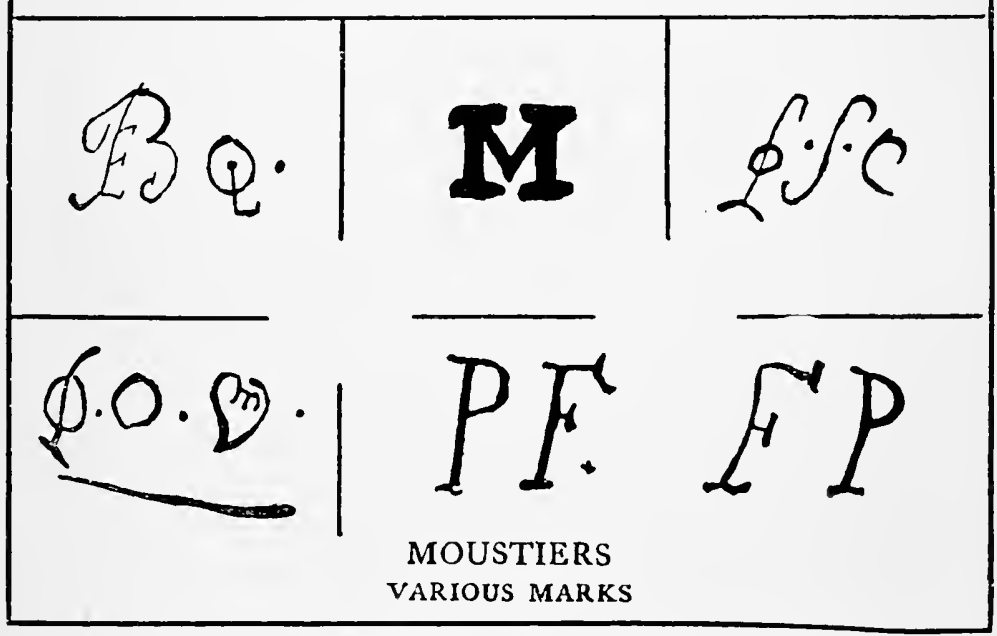

MARKS ON FAIENCE. 


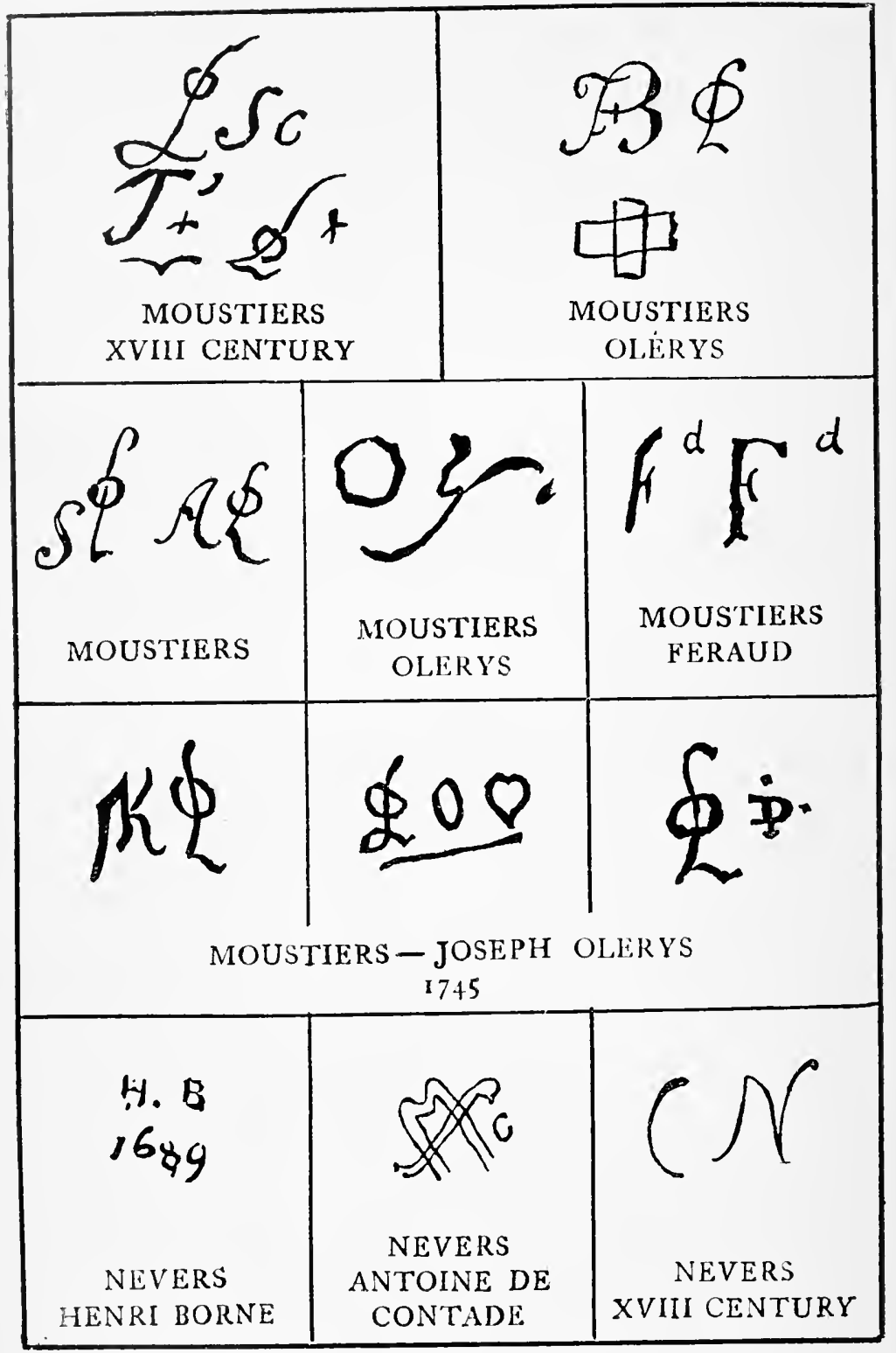

MARKS ON FAIENCE. 


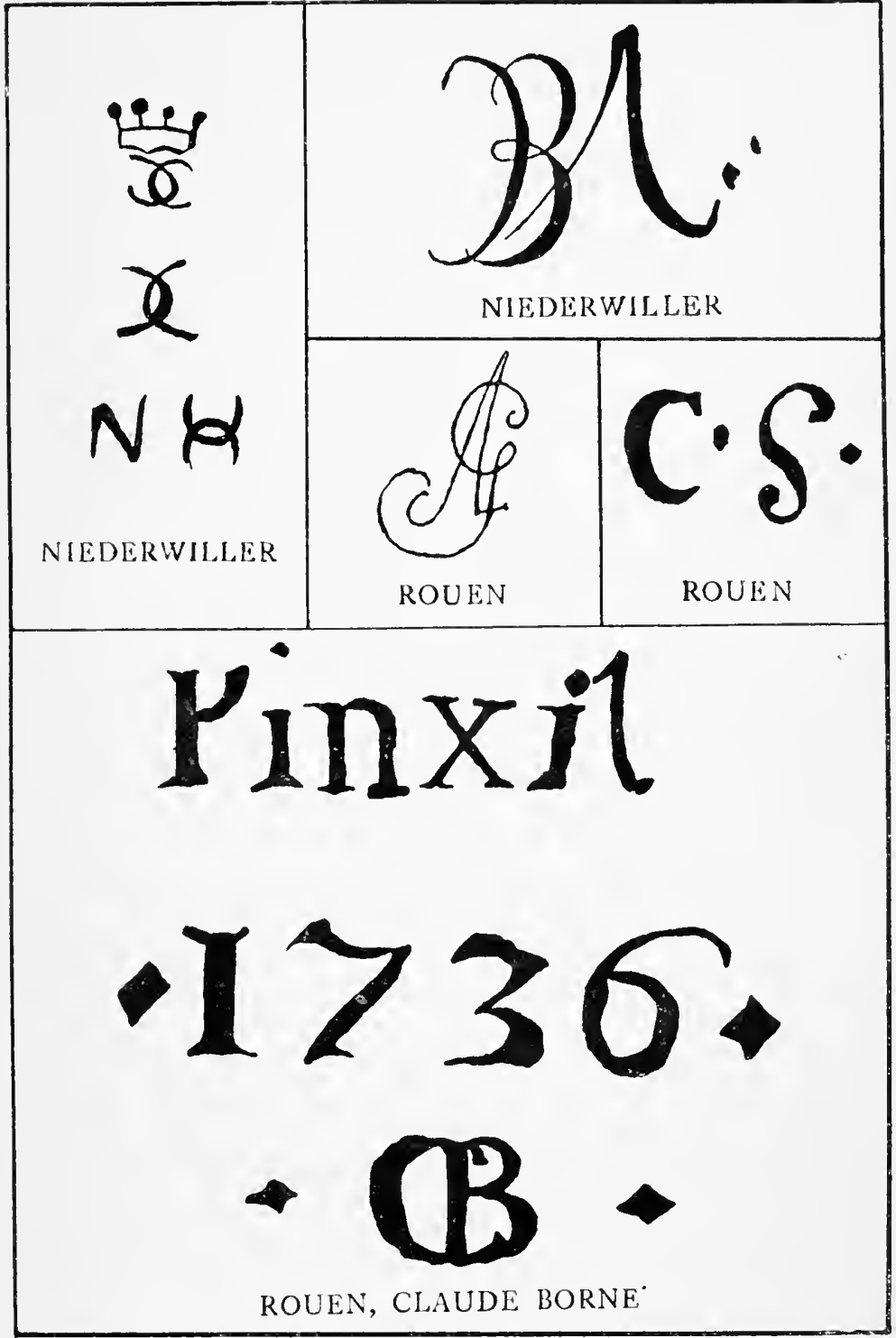

MARKS ON FAIENCE. 


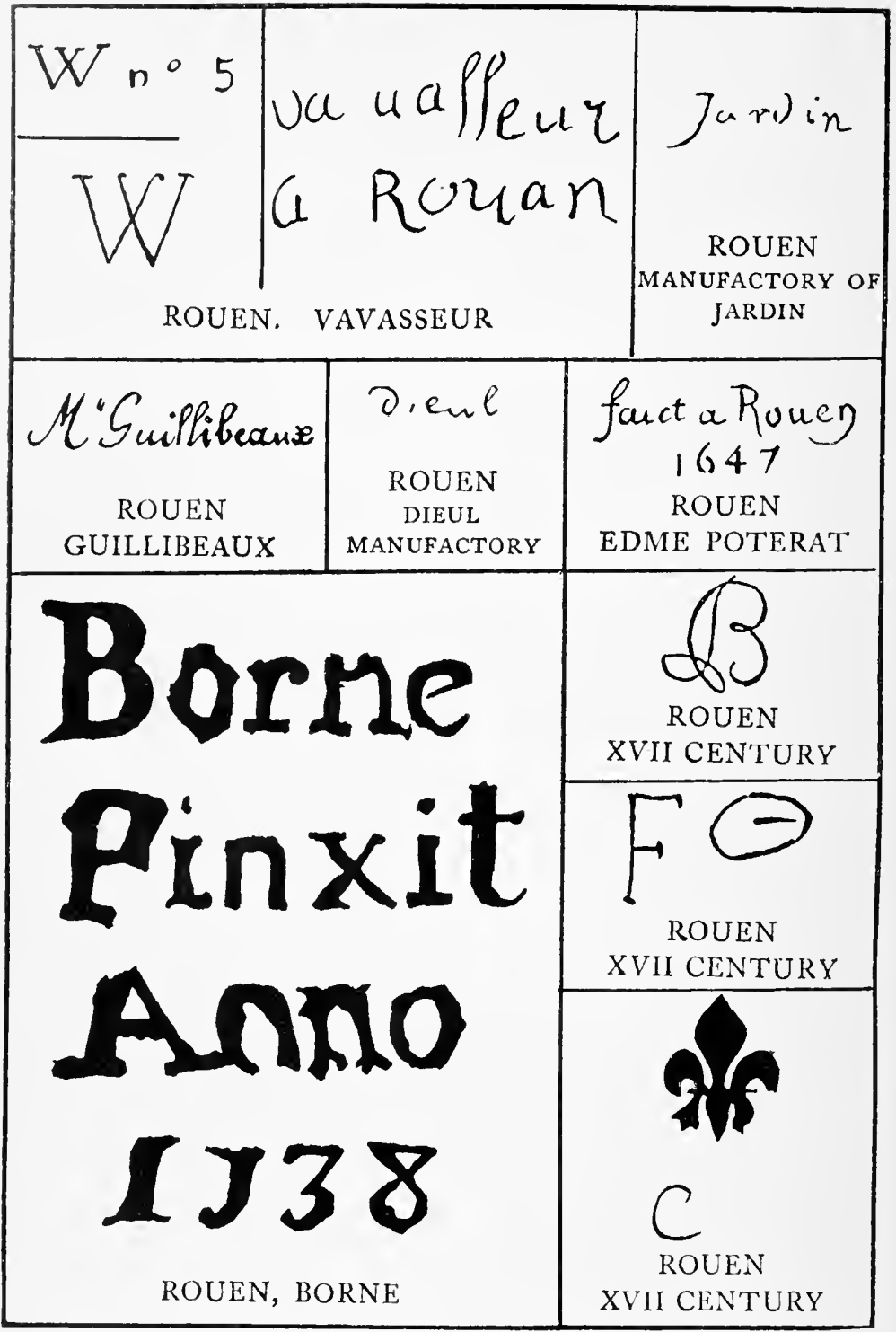

MARKS ON FAIENCE. 


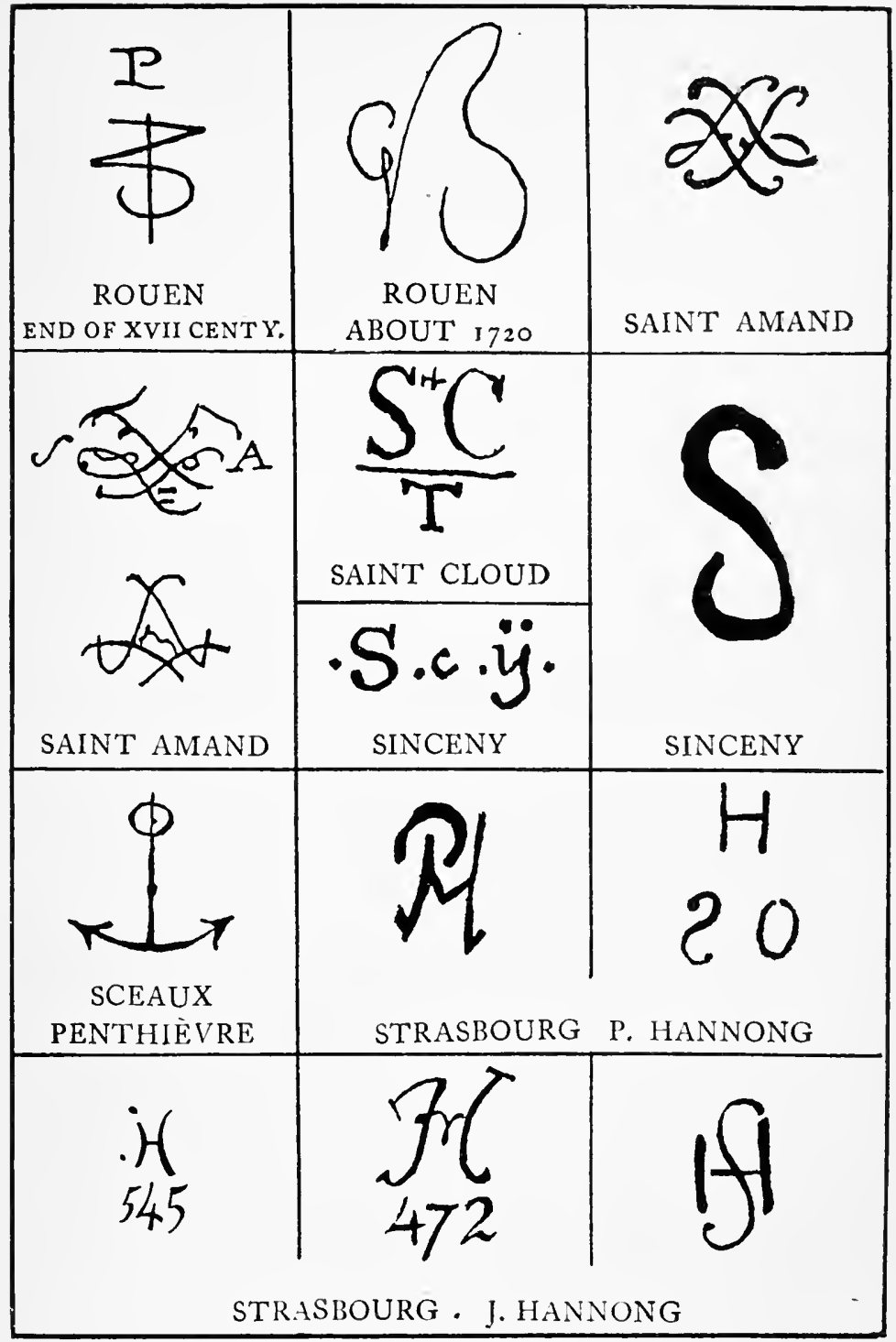

MARKS ON FAIENCE. 


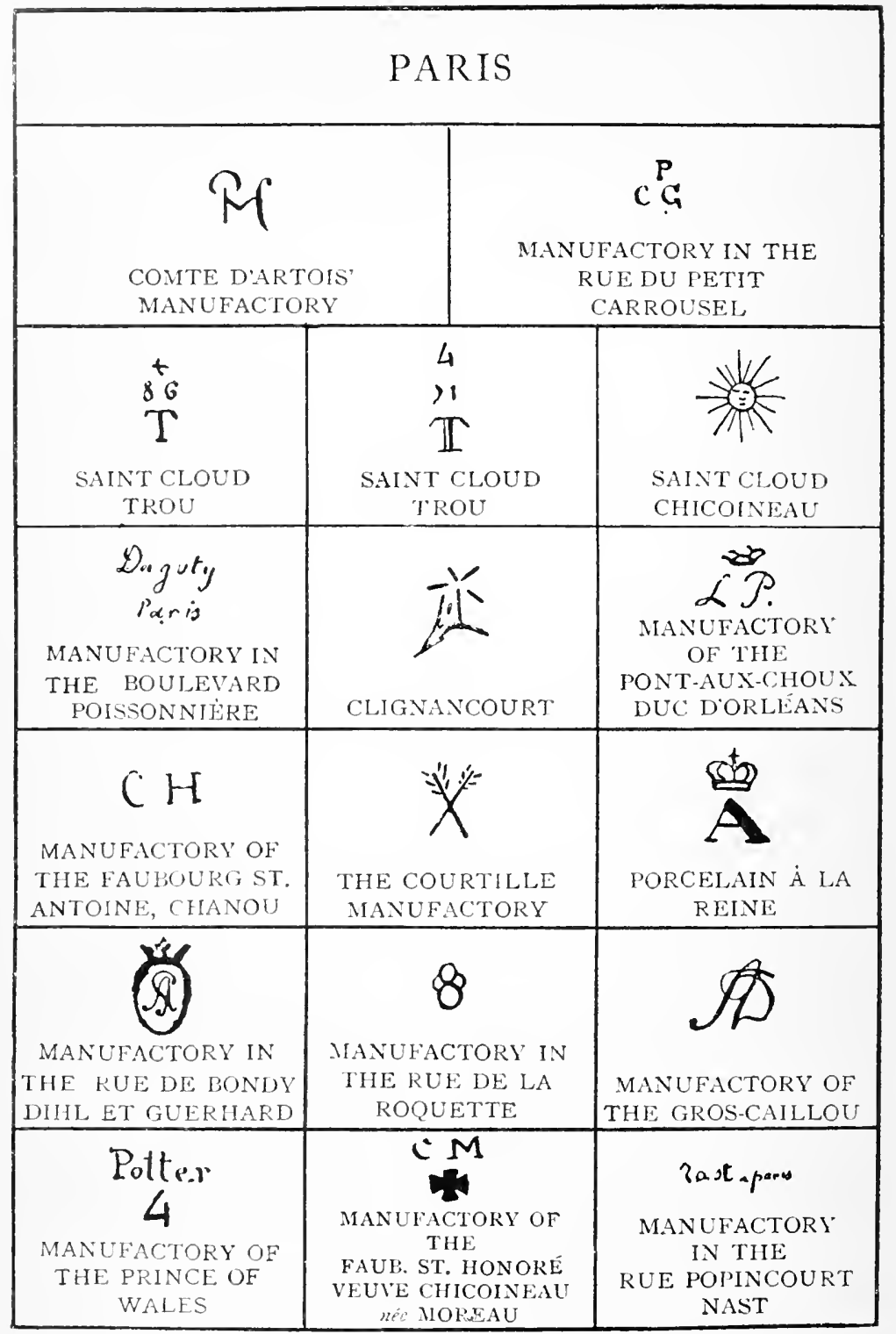

MARKS ON PORCELAIN. 


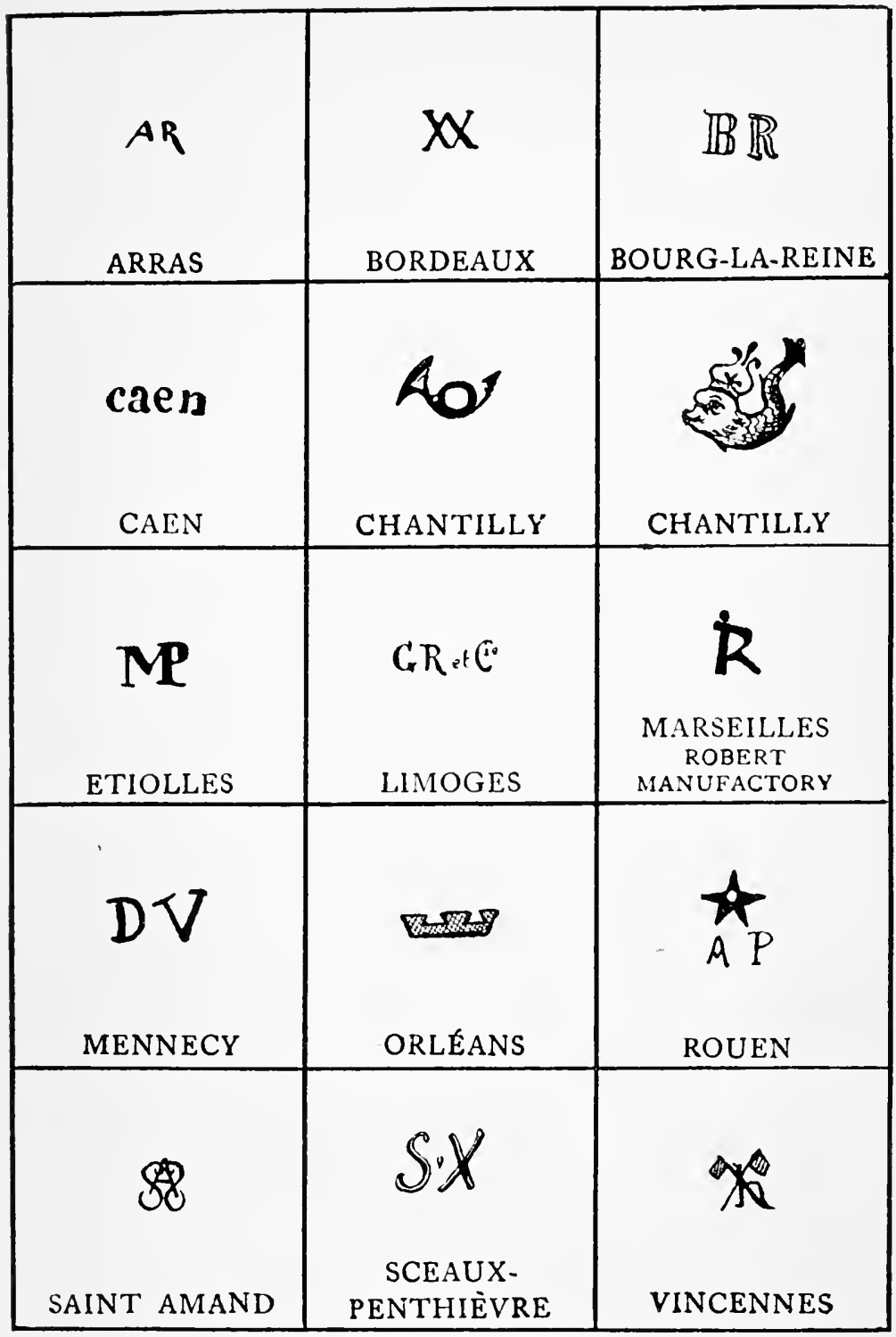

MARKS ON PORCELAIN. 


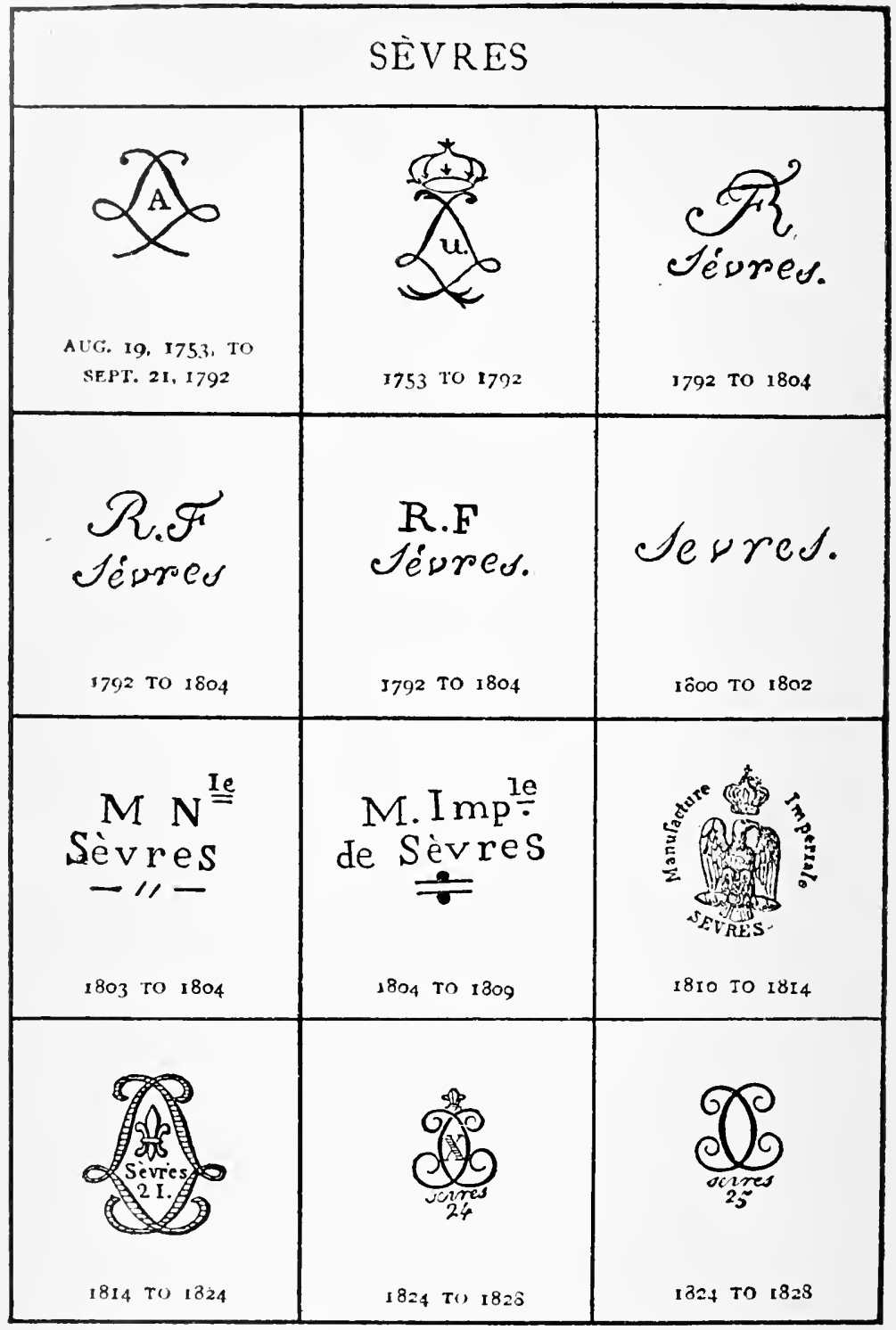

MARKS ON PORCELAIN. 
SËVRES

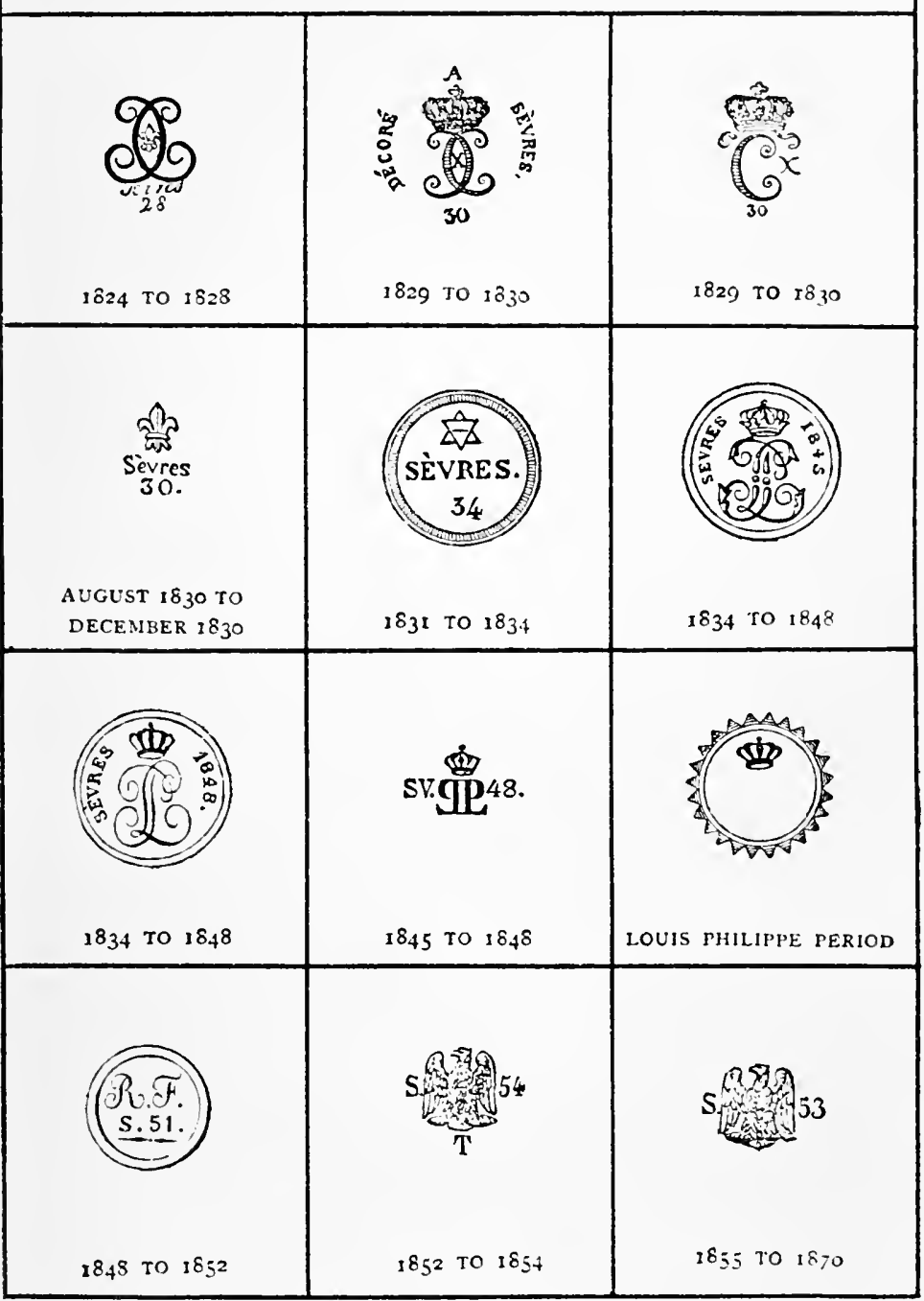

MARKS ON PORCELAIN. 


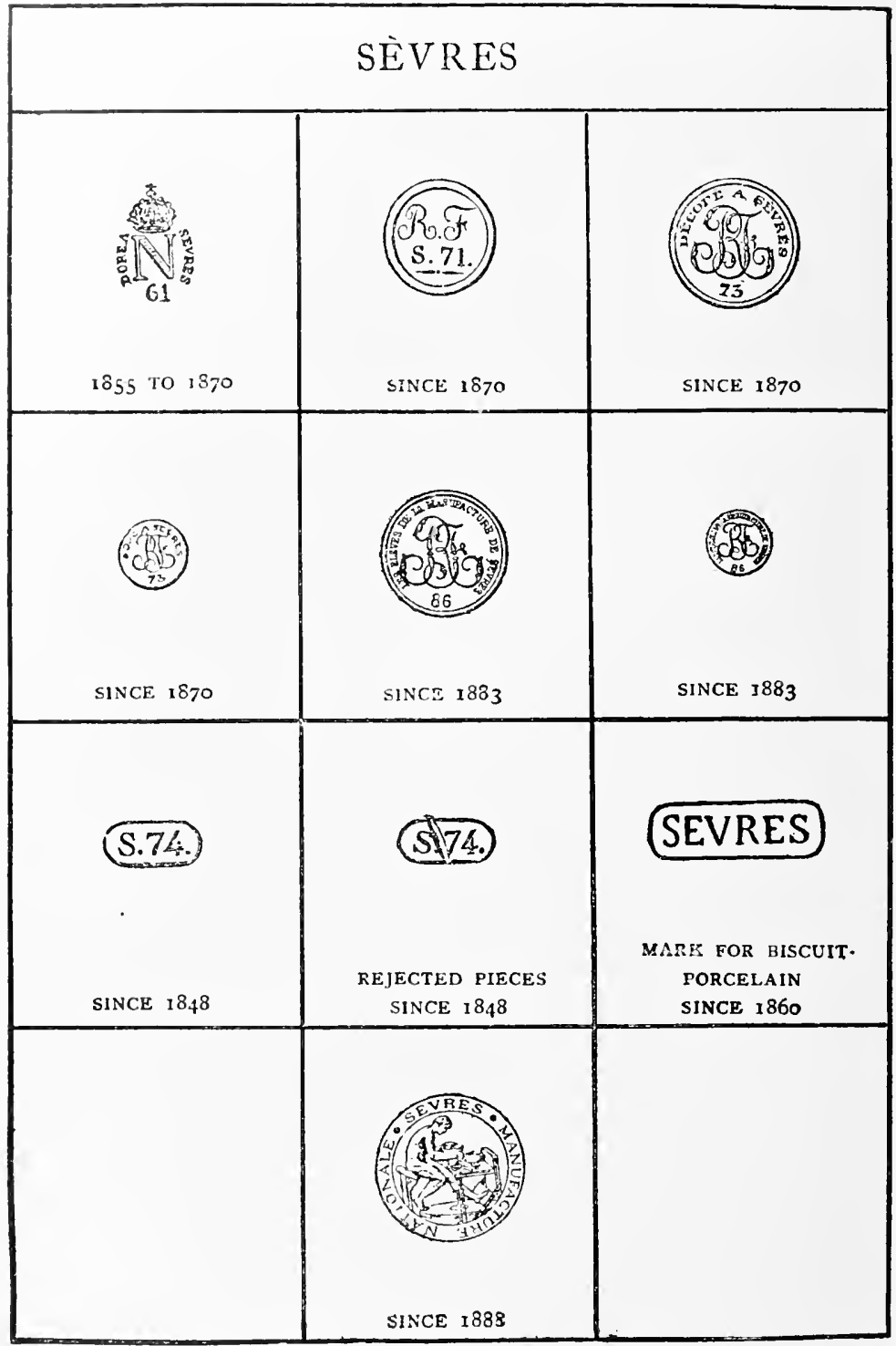

MARKS ON PORCELAIN. 


\section{USEFUL BOOKS OF REFERENCE}

Céramique du Moyen Age et de la Renaissance. By Asselineau (1876).

Une Collection de faïences meridionales. By Arnavon (I902).

Bernard Palissy. By Audiat (i868).

Les Anciennes Faïences de Bordeaux. By AzAm (1880).

Notice sur quelques Carrelages historiques. By Barthelemy ( $185^{2}$ ).

Carrelages émaillés de la Champagne. By Barthelemy (1878).

Anciennes faïenceries de la Haute Provence. By Berluc-Perussis (i886).

Les Brocs à cidre en Faïence de Rouen. By A. BORDEAUX (I868).

Traité des Arts Céramiques. By A. Brongniart (I877). Essai sur les Arts Céramiques، By A. Brongniart (i88o). Les Faïences Lyonnaises au XVIII ${ }^{\circ}$ Siècle. By P. Brossard (I 882 ).

Chefs-d'œuvre des Arts Industriels: Céramique. By P. Burty (i 866 ).

Histoire des Faïences patriotiques sous la Révolution.

By Champfleury (i 876 ).

Céramique aux expositions d'Orléans, Quimper et Reims، By Champfleury ( 1875 ).

Les Cinq Violons de faïences. By Champfleury (1876). Nomenclature de toutes les publications faites sur la Céramique. By Champfleury (i 880 ).

Guide de l'Amateur de faiences et de porcelaines By Darcel (i 864).

Old Marseilles Ware. By Henri Frantz (The Connoisseur 1902).

Antoine Cléricy* By Milet (1876). 


\section{FRENCH POTTERY \& PORCELAIN}

Les Statuettes dites de terre de Lorraine. By Morey (i 87 I).

Anciennes industries Marseillaises. By A. MortreulL (1858).

Documents sur les fabriques de Faïences de Rouen. By Delisle (1865).

La faïence, les faïenciers et les émailleurs de Nevers. By L. Du Broc de Segange (r863).

Les faïences d'Oiron. By Fillon (r862).

Les Anciennes faienceries de Montauban. By Forestie (1876).

Histoire de la Céramique Lilloise. By Houdoy (r869).

Histoire de la Céramique. By Jacquemart ( 1873 ).

Histoire de la Céramique. By Garnier (r883).

Paul Louis Cyfflé. By Joly (1864).

Recherches sur les Manufactures de faïence et de porcelaine de l'Arrondissement de Valenciennes. By LeJEAL (1868).

La Manufacture de faïence de Quimper. By LE MEN (I 875$)$.

Histoire de a faïence de Rouen. By Pottier (1870).

Histoire de faïences de Rouen. By Ris-Paquot (i870). Dictionnaire des Marques et Monogrammes. By RisPaquot (i 880 ).

Anciennes fabriques de porcelaines et de faïences de l'Arrondissement de Sceaux. By THoré (r868).

Recherches sur les anciennes Manufactures de porcelaine et faïence en Alsace-Lorraine. By TainTURIER (I 868).

Le Musée Céramique de Rouen. By Le Breton (1883).

Le Musée Céramique de Sèvres. By Papillon (1903). 


\section{NDEX}

** For Marks of Makers and Manufactories, see Plates LIX-LXX,

page $15^{2}$.

Abaquesne, Masseot, his tile pictures at Rouen, 3 ; references, I I, 29

Academy of Sciences, first Sèvres vases seen in 1769 at, 98 Accoules, Eglise des, remains of a Marseilles faience crucifix at, 53

Agnel and Sauze, a Marseilles faience pottery, 58

Alcora factory, its inception due to Moustiers, 43; bust of the Virgin attributed to, 48 ; Moustiers workmen go to, 49

Alençon, kaolin discovered there, I 756, by Guettard, 97

Aliante soda, a component of Sèvres paste, io6

Allnaud, a factory of Limoges, I 28

"Almanach de Gotha," its description of Niederwiller ware, 73

Alsace, its industry suffers, I 744, from high import duty, 70 ; references, 68,72

Alsatian style; see Decoration

America, French islands of, Marseilles faience imported to, 67

Angiviliers, Comte d', Su perintendent of Fine Arts, I 7\$9, 99

Angoulême, Duc d', factory founded by Gerard and Dihl, I 24

Antheaume, a Chantilly artist, I 22

Antiq, Charles, collection, $\mathrm{I}_{45}, \mathrm{I}_{4} 8$ Aprey, factory somewhat celebrated, decorations by Jary, 83 ; marks, plate LIX; pieces sold since I 882 , I 36
Aranda, the Count of, takes Moustiers workman to the Alcora factory, 48

Ardus, a factory of Montauban, 86

Argenteuil clay, a component of Sèvres paste, I07

Armand, jun., a Sèvres painterdecorator, $\mathrm{IO}_{3}$

Armendières, a factory in the department of Eure, 8

Arnavon, M. Louis, his collection, 47 , I 49 ; plates $\mathrm{D}, 50$; Xxxirl, 64

Arras, porcelain factory, Deleneur the best known maker, I 28 ; marks, plate Lxvir

Arrelin, Jacques, circular dish with arms of (Rowen), I 37

Artois, Comte d', factory directed by $\mathrm{P}$. A. Hannong at Paris, I 23 ; mark, plate LXvi

Ascanio, pupil of Cellini, HenriDeux ware attributed to, 4

Ashmolean Museum, Palissy specimens at, I 5, I9

Asturias, Duchess of the, presented with Sèvres pieces, IO4

Aubert, a painter-decorator of Sèvres, IO3 ; cup decorated by, I 33

Auge, Pré d', a pottery contemporary with faiences $d$ ' Oiron, 7 ; piece sold, I 886, I 37

Auriol, reference, 53

Auvillar, a Montauban factory, 86

Avignon, produces pottery from sixteenth to eighteenth century, 20

Avron, continues the manufacture of enamels after Palissy, 19 


\section{FRENCH POTTERY \& PORCELAIN}

BACHELIER, of the Sèvres factory, r 748 , quoted 88 ; his Vase des Saisons. I 12 ; references, 89, 9I, 103

Bagnol, a Limoges factory, r 28

Bagnolet, Guettard discovers true porcelain at, 97

Baraubeart, Gérault, buys an Orleans faience factory, I 27

Barbin, the first manager at Mennecy, I 23

Barry, Du, chalice with monogram of (Sèvres), I 38

Basses-Alpes, references, 49, 52

Batelier, administrator at Sèvres at the period of the Revolution, ro2

Batuex, a Chantilly artist, r 22

Baudouin, plaque decorated by (Sèvres), I 34

Baumgart, M., administrator at Sèvres factory since I $89 \mathrm{r}, 103$

Beaumont, a Montauban factory, 86

Beauvais, Henri-Deux faience attributed to, 4: its poteries azurées mentioned by Rabelais I9; its present to the queen of Francis I., 20 ; plate $\mathrm{r}, 4$

Beauvais, Delaherche, collection, I 34

Beauvallet, busts of Marat attri. buted to, I 30

Bedford, Duchess of (1763), presented with Sèvres porcelain, ro4

Bellegarde of Rouen, collection, I 5 I

Bellevue, established $175^{8}, 77$; acquires the title of the "Royal Factory," ib.; statuettes made there by Cyfflé, $i b$. ; busts of Voltaire and Rousseau, r 36 ; pieces sold since r 882 , I 36 ; references, 72,74

Benoit, employed by Prince of Wales to obtain Sèvres specimens, IO5

I 56
Berain, John, a Moustiers artist, 48

Berlin factory, reference, $\mathrm{r} 20$

Bernart, Jehan, secretary to Hélène de Hangest, 5

Bertin, a Rouen factory, 35

Bertin, Veuve Huet, a later Rouen factory, 35

Bessols, a Montauban factory, 86

Beurdeley Père collection, I 3 I

Beyerlé, Baron Jean de, founds a faience factory at Niederwiller, 73 ; reference, 74 .

Boettger, J. F., founder of the Dresden factory, 94

Boileau, Director at Sèvres, 1759, 91 ; dies, 1773, 98

Boissy, reference, 4

Boizot, a Sèvres sculptor, IO3; references, IO9, I I 3

Bolbec, a town in France, reference, 38

Bondil, Dr., on the origin of Moustiers faience, 44

Bonnefoi, Antoine, his pottery at Marseilles, 58; his mark, 59 ; reference, $6 \mathrm{r}$

Bonte, Dutch workman employed by Hustin, 84

Bordeaux, the first faience factory in south east of France in the beginning of eighteenth century, 83 ; Jacques Hustin its chief potter, ib. ; associated with Fautier, $i b$. ; its activity, $i b$. ; engagement of Bonte, 84 ; effects of his death, ib.; produces faience in imitation of porcelain, ib. ; Verneuille porcelain good in $1770, \mathrm{r} 28$; references, 69, 84, 98; marks, plate LXVII

Borelli, Jacques, his pottery at Marseilles, 59

Borely Museum, the " Good Samaritan " dish (Moustiers) at, 47 ; plates xxiv, 44 ; $\mathrm{xxv,}$ 46 ; reference, 146 


\section{INDEX}

Borne, Bertrand, a Sinceny artist, $8 \mathrm{I}$

- Claude, subjects at Rouen and Sinceny designed by, 40 ; reference, 8 I ; mark, plates LXIII, LXIV

- Henri (Nevers), mark, plate LXII

Bossu, Jean, a founder of the Lille factory, 78

Boucher, François, French painter, plaque decorated by (Sèvres), I 34 ; water jug and basin (Marseilles), decorated after, I 49 ; references, $76,8 \mathrm{I}$, I 14

Boulanger, decorator, reference, I 44

Boulevard Poissonière, a Paris factory, mark, plate Lxvi

Boulle, Rouen piece in the style of, I 45

Bourcier, Barthélemy, founds a Nevers faience factory, 24

Bourg-la-Reine, porcelain factory, I23; marks, plates LIX, LXVII

Bourgeois collection of Cologne, I 50

Bourgouin, a factory of Rennes, 85

Boussemaert, François, of the Lille factory, 79; mark, plate LIX

Boyer, of the pottery at Marseilles, 58

Breaard, of a faience factory at Rouen, 35

Bressuire, the Seigneur de, his arms on faience d'Oiron, 6

Brichard, Eloi, obtains a licence for the Sèvres factory, 90 ; reference, 9I

Briot, François, French artist, I 8 ; "Temperance " dish (Palissy), I 38

Brongniart, Alexandre, on Palissy's enamel, I 5 ; appointed director at Sèvres, IO2
Bruges, Cyfflé dies at, 77

Brument, first true Rouen piece signed by, I699, 36 ; plate xi, 29

Brussels. collection of M. Frédéric Fetis, of, I 39

Bulidon, a Chantilly artist, I 22

Busch, a German workman at Sèvres, 95

CAEN, mark, plate LxviI

Caffiéri, Jean J., a Sèvres sculptor, $\mathrm{IO}_{3}$

Callot, Jacques, French engraver, reference, $5 \mathrm{I}$

Calonne, M. de, Finance Minister of Louis XVI, reference, I22

Capelle, a Sèvres painter-decorator, $\mathrm{IO} 3$

Carnavalet, Musée, Palissy specimens at, 18

Castel, a Sèvres painter-decorator, 103

Castellane, Comte de, reference, 45

Catherine the Great, cup with her monogram (Sèvres), I 42

Caton, Mdme., a Sèvres artist, IO3

Cauchois, a factory at Rouen, 35 Causay, manager of the Quimper factory, 85

Caussy, a Rouen faience factory, 35

Caussy, Pierre Paul, reference, 35

Cécier, a Chantilly artist, I 22

Cellini, Benvenuto, reference, 4

Celly, Sieur, sells Marseilles faience at Paris, 67

Ceramic art, its late development in France, I

Chambrette, Jacques, founds, the Lunéville factory, I731, 75; the St. Clement's factory, I 750 , 76

Gabriel, succeeds his father at St. Clement's factory, 76 


\section{FRENCH POTTERY \& PORCELAIN}

Chanou, administrator at Sèvres during the Revolutionary period, IO2

Clianou, Faubourg St. Antoine factory, Paris, mark, plate LXVI

__- Mdlle, a Sèvres artist, IO3

Chantilly, porcelain factory, founded, 1725 , by Cirou, I 22 ; its sources of inspiration, and artists, ib. ; plates LV, I22, LVI, I 24, " A Market-Porter," I 35 ; "Crouching Chinaman," I 38 ; references, $87-89$, I 20, I23; pieces sold since I 882, I 32, I $35, \quad$ I 38, I 42, I 5 I ; marks, plate Lxvin

Chapelle, Pierre, maker of the Celestial and Terrestrial Globes in Rouen Museum, 39; his mark, 40 ; first manager at Sceaux factory, $8 \mathrm{I}$; plate xxI, 40

Chapelle Biron, birthplace of Palissy, 9

Charles X., his mark on Sèvres porcelain, I824-1827, I I 7 ; plate Lxvirt

Chaulnes, Palissy's grotto at, is

Chauny, a town in Aisne, reference, 79

Chazelles, a town in France, reference, 28

Cherpentier, Francois, potter, of the Château d'Oiron, 5

Chicoineau, Pierre, of the St. Cloud factory, 82 ; mark, plate Lxvi

- - Veuve, widow of Pierre, privileged to make porcelain, I695, I2 I ; mark, plate Lxvi

China; see Decoration.

Christina, Archduchess (1 786 ), presented with Sèvres porcelain, IO4

Cirou, founder, I725, of the Chantilly factory, I 22

Clerici, notary of Marseilles, probable ancestor of the Clerissys, 56

Clerissy, A., at Marseilles about I694, 45; connection with Pierre Clerissy not discovered, 56; his work compared with P. Clerissy's, 57 ; workshop re-established by Savy, 59 ; references, 58, note, 60 ; mark, plate Lx

--- Pierre, of Moustiers, white enamel method said to have been given him by a monk, 44 ; begins the factory at Moustiers, 45 ; another of the same name at Moustiers, ib. ; Viry a valuable collaborator, 46 ; mark associated with that of Viry, 47 ; his work compared with A. Clerissy's, 57 ; references, 56, 69; mark, plate LxI

Pierre II., associated with J. B. Viry at Moustiers, 48 ; ennobled by Louis XV., 50 ; marks of Clerissy and Olérys, 50 ; reference, 49

Clermont-Ferrand, pieces sold since I882, I 36 ; marks, plate LX

Cleves, Henrietta of, reference, 23

Clignancourt, Paris factory supported by the Comte de Provence, I 24 ; mark, plate Lxvi

Clodion, a Sèvres sculptor, IO3 ; reference, I I 4

Cluny Museum, early polychrome Rouen ware at, 37 ; references, 4, I 5

Colbert, Jean B., Finance Minister to Louis XIV., 32

Cologne, Bourgeois collection of, I 50

Comery, Sèvres, painter-decorator reference, $\mathrm{IO}_{3}$ 


\section{INDEX}

Condé, Prince de, reference, I 22 Conrade, Augustin, one of the first faience makers at Nevers, 23

\section{Baptiste, of Nevers, 23}

Dominique, whose sons continue the manufacture at Nevers, 23, 24; reference, 28 ; specimen sold in I 885 , I 36 ; mark plate LXII Consular period, Sèvres marks during, I 6 ; plate LxviII

Cournaille, a Chantilly artist, I 22

Courteille, M. Barberie de, Counsellor of State to Louis XV., 9I

Courtville manufactory, Paris, mark, plate Lxvi

Courtois, of Limoges, reference, 4

Coutan, M., director at Sèvres since I 89 I, IO3

Cunha, Ribeiro da, collection, I 3 I

Custine, Comte de, acquires the Niederwiller factory at the death of Beyerlé, 74

Custode, Jehan, of Nevers, banished from Normandy, 24

-_ Pierre, father of Jehan, founds a factory at Nevers, I652.24; reference. 28

Cyfflé, Paul Louis, modeller at Niederwiller, 74 ; works also for Bellevue, 77 ; subjects executed by, 75; "Belisaire Begging " group, I 39

DAIRllier, Baroness, collection, I 52

Daligné, Maitre, reference, I 39

Darcel, M., "Guide de l'Amateur des Faiences," on Rouen ornamentation, quoted, 36

Darnet, Mdme., discovers kaolin near Limoges, 97

Dauphin, the, Lille factory placed under his patronage, 122
Davillier, Baron C., author of "Histoires des Faiences et Porcelaines de Moustiers, \&c. " on the date of the Moustiers enamel. 44; cup of Robert, Marseilles, owned by, 63

Deck. Th., on the composition of Palissy's paste, I 5 ; administrator at Sèvres, I $887-189 \mathrm{I}$, $\mathrm{IO}_{3}$

Decoration, Alsatian style, 84; Chantilly's grotesque Eastern types, I 22 ; Chinese style. 26, $27,32-34,40,72,80,85,93,94$, I2I, I25; decor à la corne, $4 \mathrm{I}$, 80,85 ; decor à ferronerie, 36 ; Directory style, I I 3 ; Empire style, III, II 3 ; en camaiers, $24,27,30,39,40,42,47,79$, So, 92,93 ; en rocaille, 27,41 , 42, 7I; Etruscan designs, I IO ; Franco-Nivernese style, 26 ; Farnesina frescoes, 27 ; Henri-Deux, 6, 7 ; Italian style, 2, 22, 30, 84; Japanese style, 26,73 , I2 I ; Lille, 79 , I22; Louis-Philippe period, I Io; Marseilles, 57, 59, 6I, 65,76 ; Mennecy, I23 ; Moustiers, $22,40,44,50$; Niederwiller, 73, 75, 76 ; Paris, 123 ; Persian style, 25, 26, 4I ; Regency style, 48 ; Rouen, 3I, 36, 38, 82, 85, I 2 I ; St. Cloud, I2I ; Sèvres, 94, 95, 103, I06, I09; Sceaux, I 26; Sinceny, So; Strasburg, 7 I, 72 ; style d-à-coquille, I I 3 ; Valenciennes, I 28 ; Vincennes, I 25

Decor à la Corne; see Decoration

Dehueux, jardinières decorated by (Sceaux), I 37

Delaherche, collection of Beauvais, I 34

Delange, M., attributes HenriDeux faience to Girolamo della Robbia, 4 


\section{FRENCH POTTERY \& PORCELAIN}

Delaresse, Jean, said to have been the first worker of Marseilles faience, 55

Delarue, a Sèvres modeller, I I 2

Deleneur, porcelain maker, Arras, I 28

Delft-ware imitated by Rouen, 22, 35 ; sometimes mistaken for Lille faience, 79 ; reference, 27

Demarne, his landscape subjects at the Duc d'Angoulême's factory, I 24

Desmuraille, J. B., Saint Amand artist, 85

Desvres and Hesdin faience chiefly noticeable for quantity more than quality, 86

Deux - Flambeaux, Manufacture des, a Paris factory of 1774,124

Deux-Sèvres, reference, 4

Diarme, Domaine de la, Sèvres factory removed to, I 753,90

Dieul manufactory, Rouen, mark, plate Lxiv

Dihl, a founder of the Duc d'Angoulême's factory, Paris, 124 ; mark, plate LxVI

Directory style, Sèvres; see Decoration

Dodin, Sèvres painter-decorator, 103

Dorez, a manager at Lille, I22

Dresden, reference, $\delta_{7}$

Drolling, his landscape subjects at the Duc d'Angoulême's factory, I 24

Du Sartet sale, reference, ${ }_{4} 8$

Dubois, the brothers, their connection with the Sèvres factory, 88,89

- - of the Trois-Levrettes factory, Paris, I 24

Duchesne, his landscapes uti. lised at the Duc d'Angoulême's factory, I 24

Duplessis, M., sculptor at Sèvres, 89,103 , roo; his vases in the Wallace collection, I I I
Dupont-Auberville collection, I 35

Durot, Leperre, makes hard porcelain at Lille, I 784, I 22

Duru, sculptor at Sèvres, Io3

Dutanda, pieces decorated by, I 50

Dyck, Sir A. Van, his portrait reproduced in Sèvres porcelain, I I 5

Ebelmen, Jacques J., director at Sèvres, I 847-52, IO2

Ecouen, Château d', Rouen tiles of 1542 at, 2 ; Palissy work at, I4, I 8

Empire period, Sèvres marks, I 6, plate LxviII; reference, IO9

England, pottery from, destroys Nevers industry, 28 ; workmen from, employed at Rouen, 35 ; Marseilles faience service at Robert's factory destined

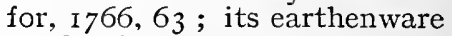
productions suggested as a branch of manufacture at Sèvres, ror ; finest Sèvres porcelain talken by, ro5

Estienne, Nicolas, founds Nevers factory, I6 52,24

Etiolles, a Paris factory, about I768, managed by Monnier, I26; marks, plate LXVII

Eure, department of, factories in, 8

FAEnza, from whence is derived the term " faience," 54

Faience; see Aprey, 83; Belleville, 77 ; Bordeaux, 83 ; Desvres and Hesdin, 86; Lille, 78; Lunéville, 75 ; Marseilles, 53; Montauban, 86 ; Montpellier, 85 ; Moustiers, 43 ; Nevers, 21 ; Niederwiller, 72 ; Orleans, 86 ; Palissy, 9 ; Paris, 82 ; Quimper, 85 ; Rennes, 85 ; Rouen, 


\section{INDEX}

Faience-Cont.

29 ; Saint Amand, 84 ; Saint Cloud, 82 ; Saint Omer, 84 ; Samadet, 86 ; Sceaux, 8I ; Sinceny, 79; Strasburg, 68; Varages, 86

Falconet, Etienne Maurice,

Sevres sculptor, I753, 90, IO3; Vase à l'Amour Falconet, I I 2

Faulchier, J., one of the oldest Marseilles potters, 58 ; soup tureen made by, plate xxviII, 53,66

Fauquez, P. J., founds Saint Amand's factory before I74I, $8_{4}$; founds Valenciennes factory, 1785 , 128 ; specimen in Fétis collection, I 39

Fautier, Jacques, joins Hustin at Bordeaux, I 7 I I-I 4,83

Faventia; see Faenza

Fayard, M., founds first Sinceny factory, 1737,79

Fayence (Var), the fabrication of French faience first established at, 54,55

Febvre, A., senr., collection, I 30

Febvrier, Jacques, founds the Lille factory, 78 ; succeeded by Boussemaert, 79

Feraud, Moustiers, mark, plate LXII

Ferdinand, Archduke ( 1786 ), presented with Sèvres vases and groups, 104

Ferdinand IV. his Naples mark sometimes mistaken for that of J. G. Robert, Marseilles, 64

Fernig, Joseph, Saint Amand, pieces ornamented by, 85 ; designs Valenciennes paintings, I 29

Ferrara, reference, 23

Fesquiet, Veuve, faience maker, Marseilles, 58

Fétis Collection, specimen from, plate F, 80 ; sale, I 887 , I 39

Fickaert, artist. reference, I 29 Fillon, Benjamin, on the origin of Henvi-Dentx ware, 4; his collection, I 30

Fitzhenry, J. H., piece from Chantilly in his collection. plate LVI, 124

Flandain, a Rouen faience factory, 35

Flemish workmen employed, at an early period, at Rouen, 35

Florence, the origin of HenviDeux ware attributed to, 4 ; references, 23, 46

Floris, Frans, his works reproduced by Viry in faience at Moustiers, 46

Fontainebleau, sand there a component of the Sèvres paste, I06, IO7; reference, I9

Forasassi, factory at Rennes, 1748,85

Fossé, a Rouen faience factory, I 740,35

Fouque, a Rouen workman, related, probably, to Joseph Fouque, Moustiers, 35

- Joseph, Moustiers, partner of Pierre Clerissy II., 35, $50,5 \mathrm{I}$

- M. E., traces Pierre Clerissy in 1686,44

Fountaine collection, I 32

Fournier, Père, collection, I 33

Fourneira, founder, 1733, of Limoges factory, I 27

Francis I., writes verses for Hélène de Hangest, 5; his queen presented with Beauvais Vases de Savignies, 1520, 20 ; reference, 2

Frankenthal, Paul Hannong founds a factory at, 70 ; references, 71,96

French ceramic art in the sixteenth century : its development relatively late, I ; influenced by Italian potters, 2 ; tile pictures of I542 by Abaquesne, 3; manufacture of pottery ceases for two 


\section{FRENCH POTTERY \& PORCELAIN}

French Ceramic Art-Cont. centuries, ib. ; factory at Lyons, 1556 , ib. ; inactivity probably due to Limoges enamels, $i b$. ; origin of HenriDeux ware doubtful, 4 ; its institution at Oiron, 5 ; its characteristics, $i b$. ; characteristics of second period, 6 ; its decadence, 7 ; rarity of specimens, $i b$.; the pottery of Pré d'Auge, $i b$.; other factories in the department of Eure, 8

French faience and porcelain sold since I 882 , list of pieces, I 30

Fritsch-Estrangin collection ; pieces from plates XxIII, 42 ; xxxi, 58

Fulvi, M. de, deceived by the brothers Dubois, 88 ; effects of his death on the Sèvres company, 90 ; reference, 89

GaMEL, M., water jug and basin (Moustiers), "Diana at her Toilet," plate xxvir, 49, 52

Garnier, E., his " Histoire de la Céramique," reference, 17 ; on Rouen style, quoted, $3 \mathrm{I}$; on Sèvres ware, quoted, 94 ; on composition of Sèvres paste, quoted, I06 ; references, I8, 3o, 72

Genest, French painter at Sèvres, I 753,90

George IV. ; see Wales, Prince of Gerard, Albert, collection, I45, I46, I48

Gérard, Baron, his " Psyche " reproduced at Sèvres, I I 5

Gerhard, a founder of the Duc d'Angoulême's Paris factory, 124

Germany, references, 70, 94

Giraudeau bequest, Louvre, includes fine example of Oléry's polychrome faience, 49

Girodet, A. L., his "Atala" reproduced at Sèvres, II5

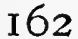

Globes, celestial and terrestrial, of Pierre Chapelle in Rouen Museum, plate xxI, 39, 40

Glot, a manager at Sceaux facfory, 8I, 139

Godin, Esmé, founds a Nevers faience factory, 1652,24

Gobelins, "Royal Manufacture of Furniture," 88 ; its suppression demanded by the revolutionaries, IOI

Goldschmidt, S., collection, 140, 147

Gonzaga, Ludovico, reference, 23

Gotha, German factory of, note, 64

Gouellain, M., quoted, 27

Gouffier, Artus, tutor to Francis I., husband of Hélène de Hangest, 4

- Claude, son, continues the manufactory at Oiron, 6 ; reference, 7

Grangel, Spanish painter, designs for Moustiers, 50

Gravant, becomes chief workman at Chantilly, 89

Greece, reference, 64

Grellat, a founder of Limoges facfory, I 27

Greuze, piece from Sceaux decorated after, 146

Grignan, Château de, the residence of Madame de Sévigné, reference, 45

Grison, Sèvres piece decorated by I 33

Gros-Caillou factory, Paris, mark, plate LXVI

Guettard, Jean Etienne, discovers kaolin near Alençon, I 756, 97

Guibal, sculptor, collaborates with Cyfflé at Lunéville, 1746, 77

Guillibaud factory, Rouen, polychrome examples at Cluny attributed to, 37 ; its figure subjects, 40 ; piece in D'Yvon collection, I43; mark, plate IXIV 


\section{INDEX}

Guillibaud factory, Veuve Loüc, of the Rouen factory, I740, 35

Haguenau, Charles Hannong, establishes factory at, 69 ; Paul Hannong purchases it from his brother Balthasar, 70

Hangest, Hélène de, manufactures faience d'Oiron, I 524, 4 ; dies, 5 ; reference, 6

Hannong, Balthasar, succeeds his father at Hagenau and sells it to Paul Antoine Hannong, 70

—_ Charles, founds Strasburg factory, 1709, 69 ; takes Wackenfeld into partnership; establishes Haguenau factory, 69, 95 ; one of his productions, described by $\mathrm{M}$. Jacquemart, 95 ; reference, 7 I

Joseph Adam, son of Paul A. Hannong, continues the trade after his father goes to Frankenthal, 7o; incurs loan from Cardinal de Rohan; is imprisoned and factory sold, I 780,7 I ; succeeds his father at Sèvres but fails to come to an agreement there, 97 ; marks, plate $\mathrm{LxV}$

Paul Antoine, son of Charles Hannong, succeeds to Strasburg factory and buys Haguenau from his brother Balthasar, 70 ; objects manufactured during his management, 72 ; joins Lowenfinck, 96; Sèvres reminds him of its privileges, $i b$. ; offers his services to Sèvres, $i b$. ; fails to agree with Sèvres; is prosecuted; leaves the country and founds Frankenthal, ib. ; makes hard porcelain in 1769 at Paris,
Hannong, P. A.-Cont.

123; references, 7 I, I27 ;

mark, plate Lxv; faience specimen, plate xxxviı, 70

Hannong, Pierre Antoine, son of Paul A. Hannong, continues the trade after his father goes to Frankenthal, 70; negotiates with Sèvres factory and secures cash payment and annual pension, 97

Hellot, Jean, French chemist, superintendent of chemical processes, Vincennes, I 748, 89; invents sky-blue turquoise colour at Sèvres, I06

Henry II. of France, faience d'Oiron ornamented with his cypher coupled with that of Diane de Poitiers, 4, 6, 7 ; Palissy's imprisonment a result of his edict, I 562 , I 4

Henri-Deux faience, its origin, 6 ; see also Oiron, faience de, and St. Porchaive

Héroard, Jean, extract from his journal relating to the Avron ware after Palissy, I9

Hettlinger, M., director at Sèvres until I $800, \mathrm{IO}_{2}$

Heugue, Rouen faience factory, I 720,35

_- Guillaume and François, faience factory at Rouen, I 740,35

Himbert, a Sèvres artist, IO3

Hirschvogel of Nuremburg, Palissy said to have obtained his enamel from, 9 ; note, Io

Höchst, references, 69, 70, I 20

Holland, references, $32,33,34$

Houdon, Jean Antoine, sculptor associated with the Sèvres factory, I I 4

Hustin, Jacques, of Bordeaux, I7II, 83 ; engages Bonte, a Dutch workman, 84 ; reference, 69 


\section{FRENCH POTTERY \& PORCELAIN}

INDIA, reference, I 2 I

Ingres, Jean A. D., French painter, suggests to Sèvres the reproduction of old masters, I I 5

Inkstand of Marie Leczinka, plate xxII, 4I, I I 2

Iquelon, Marquis d', collection, 141

Isabey, his portraits used by the Sèvres factory, I 10

Ivry, Baron L. d', collection, I 32

JACQUEMART, M., on the date of Robert's Marseilles factory, 62; on one of Hannong's first productions, 95 ; references, 67 , I 28

Jacques, a manager at Mennecy, 1773,123

Japan ; see Decoration

Jardin (Rouen), mark, plate LxIV

Jardyn, Karel du, Dutch painter, reference, 59

Jary, painter, associated with the Aprey factory, 83 ; piece decorated by, I 36

" Journal des Fétes," its account of the Comte de Provence's (afterwards Louis XVIII.) visit to Robert's and Savy's factories, Marseilles, 6o, 6I

Jullien, a manager at Mennecy, 1773,123

KaOLIN, discovered at Alençon by Guettard, 97, by Madame Darnet, near Limoges, $i b$.

Kilian, German engraver, his landscapes utilised at Niederwiller, 74

LA BÉRAưdìnE collection, I 34

La Courtville factory, Paris, founded about I774, I 24

"La faenze," origin of the term, 54

La Rochelle, references, I4, 69

La Roquette, rue de, factory. Paris, mark, plate, Ixvi

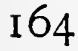

La Tremouille family, arms used to embellish faience d'Orion, 6

Lafaulotte, De, collection, I 37

Lambisc, the meeting-place of the Provençal parliament, 45

Lamoninary, of the Valenciennes factory, i 28

Landes, references, 83, 86

Lanfrey, manager at Niederwiller factory, 74

Larue, sculptor, Sèvres factory, 103

Laugier, associated with Olérys. Moustiers, 49 ; specimen from Gamel collection, plate XXVIr, 52

Lauraguais, Comte de Brancas, discovers hard paste in l'Orne, I 7 58, 97

Lauth,Ch., administrator, Sèvres, I 879-87, IO3

Laval, Gilles de, his arms on faience d'Oiron, 6

Le Blant, M., on the date of Robert's Marseilles factory, 62

Le Bœuf, André Marie, makes, at Paris, the celebrated porcelaine à la Reine, 124

Le Breton, Gaston, his studies on the ceramics of Rouen, reference, 29

Le Cerf, Joseph, French painter, associated with Sinceny factory, 8I

Le Jeune, Pierre, pieces decorated by (Sèvres), I 34

Le Riche, sculptor at Sèvres, 103

Lebel, junior, painter-decorator, Sèvres, IO3

Lebrun, Charles, director of the Gobelins factory, reference, 88; Orleans factory managed by ( I 808-I I), I 27

Leczinka, Marie, wife of Louis XVI., her inkstand, plate xxIr, 4I, I I 2

Ledoux, piece (Sèvres), with mark of, r 38 


\section{INDEX}

Lefrançois, Sieur, establishes Bellevue factory, 1758,77

Leguey, vases made at Paris factory painted by, I 24

Leleu, designer at Gillibaud's factory, Rouen, 40

Lelong, Mdme., collection, I 50

Lemire, modeller, associated with Niederwiller factory, 74 ; subjects by, 75 ; statuette by at South Kensington Muscum, plate XLII, 76

Leroux collection, 146

Lesdiguières, François de Bonne, French Protestant general, reference, 54

Levavasseur, establishes Rouen faience factory, I788, 35 ; pieces from his atelier, I 51 , I 52 ; reference, 69; marks, plate, LXIV

Levesque, Claude, reference, 28

Lille faience factory founded by Jacques Febvrier and Jean Bossu, 78 ; Boussemaert succeeds Febvrier, 79 ; largeness of its operations, $i b$. ; products often attributed to Delft or to Rouen, ib.; reference, 87 , marks, plate, IIx; porcelain resembles that of St. Cloud, I22; hard porcelain made, 1784, by Leperre Durot, ib. ; under the patronage of the Dauphin, ib. ; its ornamentation, $i b$. ; pieces sold since I 882, I 34, I 39, I 40

Limoges factory, its enamels, 3 ; established, 1773, by Messiè with the brothers Grillat and Fourneira, 127 ; its financial results, $i b$. ; acquired by Louis XVI., I $784, i b$. ; re-sold during the Revolution, $i b$. ; the factories of Minnerie, Bagnol, and Allnaud, ib. ; reference, 97 ; piece sold I888, I40; mark, plate LXVII

Limoges Museum, specimens of Moustiers faience at, 50 ; wall fountain (Limoges) bought for, I 40 ; plate (Lille) acquired by, ib.

Lisbon, Ribeiro da Cunha collection of, I 3 I

Locrée, manages the La Courtille factory, I 24

Lorges, Mdme. de, Rouen piece with arms of, I 35

L'Orne, reference, 79

Lorraine, enamelled earthenware bust of Louis XV., in Leroux collection, I47 ; reference, 72

Louis-Philippe period, Sèvres ware over-decorated during, I IO ; marks, II 7 , plate LXIX

Louis XIII., his ordinance relating to dishes, 39

Louis XIV., sends his gold plate to the mint, 32 ; his sumptuary laws favourable to the progress of pottery, 46; his mark on St. Cloud pieces, $1702-$ I5, I2I ; references, 3I, 45, 73, 87 , I IO, I I I

Louis XV., ennobles P. Clerissy II., 50 ; under the influence of Madame de Pompadour encourages ceramic art. 88 ; gives largely to the Sèvres company, 89; has a substantial share in its capital, 90; revokes the Sevvres licence and returns shareholders' money, 91 ; appoints Règnicr as director, 98 ; Madame de Pompadour, anecdote of, I26; references, 66, 94,98 , I05, IO9, I IO, I I I , I I 6

Louis XVI., decides to carry on the Sèvres factory at his own expense, IOO; his payments thereto in 1790 , IO3; references, 7 I, 80, 99, IOI, IO5, I I I, I 6

Louis XVIII., reference, 60

Louvre Museum, exhibits Abasquesnes Rouen tiles, 3 ; Nevers bottles and vases, 26 ; Olérys piece, Moustiers, 49 ; 


\section{FRENCH POTTERY \& PORCELAIN}

Sèvres vases made during Regnier's directorship, 99; the Vase Medicis, II 2 ; reference, I 5

Löwenfinck, collaborates in Paul Hannong's factory, 7 o, 96

Loyal, Charles, succeeds Chambrette at St. Clement's factory, 76

Loysel, Antoine, his name on Savigny ware at the Sèvres Museum, 20

Lully, Jean Baptiste de,reference, 90

Lunéville factory. founded, I73I, by Jacques Chambrette, 75 ; he sets up a factory at St. Clement, $i b$.; his successors, $i b$. ; differences between the pieces of Lunéville and Strasburg, ib. ; statues by Cyffle, 77 ; Cyffle's work and career. ib. ; references, 69,72 ; specimen of faience, plate XuIII, 78 ; piece sold, I 887, "Bélisaire Begging," I 39

Lyons, factory of faience there in I 556,3

Macarel, M., produced Rouen faience, I740, 35

Macquer, Pierre Joseph, French chemist, tests kaolin discovered by Madame Darnet, 98

Madrid, Château de, ornamented with della Robbia's faience, 2

Maestricht, reference, 69

Malétra, Nicolas, Rouen faiencemaker, 1740, 35

Malicorne, a factory producing faiences d'Oiron, 8

Manchester, Duchess of ( $17 \delta_{3}$ ). presented with a Sèvres service, 104

Mante, Th., reference, 58

Mantua, Duke of, reference, 23

Marie Antoinette, supports Le Bœuf's factory at Paris, I 24

Marks of makers and factories, plate $\mathrm{LIX}-\mathrm{Lxx}, \mathrm{I} 52$

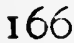

Marseilles faience factory, its faience increasing in value and estimation, 43; ceramics an ancient art in South of France, 53 ; fifteenth century bricks or tiles, $i b$. ; ancient crucifix, $i b$. ; faience first made at Fayence, in France, 54 ; not to be confounded with Faenza, ib. ; St. Jean du Dèsert the first factory, 55 ; Jean Delaresse said to have been the first producer, $i b$. : signature of $\mathrm{A}$. Clerissy in 1697,56 ; Faulchiers the next oldest factory, 58 ; brilliant whiteness of its enamel, 59 ; Savy re-establishes Clerissy's workshop, $i b$. ; supported by the Comte de Provence, 60, 6I ; his green enamel, $i b$. ; Robert the chief glory of Marseilles ceramics, 61 ; supposed date of his establishment, 62 ; visited by the Comte de Provence, 62, 63 ; his signature and marks, 64 ; his dish at Sèvres, services and pieces, $i b$.; the faience of Veuve Perrin, 65 ; remarkable pieces by Fauchier, 66 ; largeness of trade in 1766 , 67 ; style of ornament compared with that of Strasburg and Lunéville, 76 ; imitated by Sinceny, 8o; and Montpelier, 85 ; references, 2, 36 , $40,45,47,49,72$, I 24, I 27 ; plates E, 60, xxvi, 48, xxvir, $53, \mathrm{xxIx}, 54, \mathrm{xxx}, 56$, XxxI, 58, xxxII, 62, xxxIII, 64 ; xxxıv, 65 ; marks, plates LXVII, LIX, LX ; pieces sold since I $882,143.146,149$, I 50

Marseilles, Arnavon collection of, I 49

Mathieu, Sieur, associated with the Sèvres factory, 89

Mayence, reference, 69

Maze-Sencier, opinion concerning 


\section{INDEX}

Clerissy's factory, note, 60 ; his collection, I 36

Medici, Catherine de, commissions Palissy to malie a grotto at the Tuileries, I 4

Meissen factory, its secrets carefully guarded, 69; France's efforts to rival, 95 ; references, 70,87, I 20, I 25, I 26

Mennecy, porcelain factory, founded by the Duc de Villeroy, I23; productions much sought after, ib. ; its productions and managers, $i b$. ; references, 87 , I20 ; plate LVIr, I26; mark, plate LxVII; pieces sold since $1882,135,138$

Merault, aink, piece decorated by (Sèvres), I 34

Messié. founds porcelain factory, 1773 , at Limoges, 127

Meyer, director at Sèrres, IO2

Mèzeray, François E., French historian, reference, 54

Micaud, painter-decorator at Sèvres, IO3

Milet, collection of the Sèvres manufactory, I $3 \mathrm{I}$

Minnerie, factory at Limoges, 1794,128

Monnier, manager, 1768, of Sceaux factory, I 26

Montauban, its factories, 86

Montmorency, Constable de, Abaquesne makes tiles for, 3 ; intervenes on behalf of Palissy, 14 ; reference, 2

Montmorency. Henri de, Duke of Luxemburg, orders service of Rouen polychrome faience, 37; piece ornamented with arms of, 137

Montpellier faience factory, chiefly imitates Marseilles and Moustiers, 78, 85

Montpensier, Duchess de, reference, 19

Montreuil, on the origin of the term "faience," 54; on the first production of Marseilles faience, 55

Montucla, Jean Etienne, urges reduced output at Sèvres after the Revolution, 99

Moreri, Louis, on the origin of the term "faience," 54

Morin, painter-decorator at Sèvres, $\mathrm{IO}_{3}$; piece decorated by, I 44

Moustiers faience factory. imitates Italian style, 22 ; Nevers influenced by, 27 ; ceramics benefit by sumptuary laws, 3I, 46 ; utilises Chinese style, 40 ; relative value of Moustiers and Marseilles specimens, 43 ; its influence on manufactories of France and Spain, $i b$.; its inception of the Alcoro factory, $i b$. ; imitated by Nevers and Rouen, 44; theories as to date of commencement, ib. ; faience mentioned in 1694,45 ; Viry a valuable collaborator of Clerissy, 46 ; its superb dishes, $47 ;$ urns and panels, ib.; Clerissy's successors, 48 ; workmen taken to Alcora, 49 ; Olérys returns with secret of polychrome, $i b$.; sets up factory with Laugier, $i b$. ; water jug and basin in Gamel collection, ib. ; description, ib. ; marks of Olérys, 50; piece signed by Roux at Limoges, ib.; Olérys imitated by local factories, $2 b$. ; Clerissy II., ennobled, $i b$.; gives up factory, 1747 , 51 ; reputation main. tained by Fouque, $5 \mathrm{I}$; subsequent decadence, 51,52 ; references, $26,28,35,56,57,66,68$, $78,83,86$, 127, plates $\mathrm{D}, 50$. xxIv, 44, xxv, 46, xxvi, 48 , XXviI, 52 , xxxiv, 65 ; marks. plates LXI, LXII ; pieces sold since $1882,135,136,1_{3} 8,1_{39}$, I $40,143,146,149,15$ I, 152 


\section{FRENCH POTTERY \& PORECLAIN}

Musical inscriptions on Plates, plates XVI, 35, XVII, 36, 4I, I 5 I

Nantes, Italian potters established there at period of the Renaissance, 2

Naples, Royal factory at, reference, 64

Napoleon I., subject of the Olympic épergne, II 3 ; bust by Nast, I 30

Napoleon III. period, Sèvres marks during, I17; plates LXIX, Lxx

Nast, C., busts of Napoleon and Hoche by, I30, mark, plate LXVI

Negrepelisse a factory of Montauban, 86

Nesles, adorned with Palissy work, I 8

Nevers faience, progress of the art in seventeenth and eighteenth centuries, 2I; more imitative than inventive, 22 ; influenced by Italy, 23, 25; Conrades the first manufacturers, ib. ; Bourcier, Estienne, Custode and Godin establish factories, 24; characteristics of Custodes, $i b$. ; second or Persian style, 26 ; later influence of China and Japan, $i b$. ; FrancoNivernese style, $i b$. ; relapse into imitation, 27 ; influenced by Moustiers and Saxony, 28 ; its decadence, ib. ; always copied Rouen, 30 ; references, $3 \mathrm{I}, 43,44,68,78,79$, 80 ; plates $\mathrm{B}, 2 \mathrm{I}, \mathrm{C}, 28$, viII, $22, \mathrm{IX}, 24, \mathrm{x}$, 26 , marks, plate LXII ; pieces sold since I 882 , I 3 I, I 36 , I 37 , I $38, I_{39}, 1_{40}, 1_{42}$, I 45 , I 46 , I 47, I 48 . I 52

Nevers, Dulke of (1565), reference, 23

Nevers Museum, imitations of Rouen faience at, 27 ; reference, 28

I 68
Niederwiller faience, influenced by Strasburg, 72; Beyerlé opens a factory in 1704,73 ; his wife a true artist, $i b$. ; employs workmen from Saxony, $i b$. ; its productions, $i b$. ; its imitation of folded down paper, a speciality, 74 ; factory acquired by De Custine, $i b$. ; continued later by Lanfrey, $i b$.; employs Cyfflé and Lemire, $i b$. ; subjects executed by them, 75 ; references, 77 , I $27, \mathrm{I} 28$; plates $\mathrm{xxxIx}, 72, \mathrm{xL}$, 73, XLI, 74, XLII, 76 ; marks, plate IXIII ; pieces sold since I 882 , I 37,138

Nivard, Marie Louise, Rouen piece bearing the name of, I 34 Nuremberg, references, 9, note, IO

Observatory, Church of the, early specimen of terra-cotta at, 53

Ognes, d', factory, products similar to those of Sinceny. 80

Oiron, faience de, its origin and characteristics, $5,6,7$; pieces sold since I 882, I 32 . See also St. Porchaire and Henri-Deux faience

Olérys, Joseph, assists Clerissy, 49 ; goes to Alcora, $i b$. ; borrows from Callot, $5 \mathrm{I}$; plate xxvir, 52 ; mark, 50, plates LXI, LXII

Ollivier, manages a Paris factory, 124

Orleans faience, factory worked in the style of Strasburg, 86; Pierrot makes imitation porcelain, in 1686, 127; faience and porcelain made in 1757 by Gerault-Baraubeart, $i b$., rarity of its productions, $i b$. ; managed by Lebrun, $i b$. ; marks, plate LXVII

Orleans, Duchess of ( 1709 ), on the destitution in France. quoted, 3 I 
Orleans, Duke of ( 1608 ), his little " Nurse " after Palissy, I9

(1709), sends his gold plate to the mint, 32

(1784), supports the Paris factory, I25 ; mark, plate LXVI

Orry, M., Comptroller-General of Finances, superintends Sèvres factory, I748, 89 ; effects of his death, 90

Osmond, Marquis of, collection, I 33

Palissy, Bernard, his birth, 9 ; the secret of his enamel, $i b$.; settles at Saintes, Io ; abandons glass-painting for pottery, $i b$. ; searches for white enamel, I I ; his disappointments, I I, 12 ; invents the cassette, and achieves success, I 3 ; truthfulness of his methods, $i b$. ; works for De Montmorency, I4 ; becomes a Protestant, ib.; imprisoned $1562, i b . ;$ released through De Montmorency's intervention, $i b$.; settles at La Rochelle, moves to Paris, $I_{5} 65, i b$.; assisted by his sons, $i b$. ; re-arrested, I 588 , and dies in prison, I 590 , I 5 ; his work divisible into three periods, $i b$.; first period, $i b$.; his glaze, I6 ; second period and method, I 7 ; third period, I 8 ; his attitude towards cheapness and competition, $i b$. ; Avron factory continues his style, I9; references, $3,7,8,2 \mathrm{I}$; Plates, A, frontispiece, I I, 9, III, I0, IV, I 2, v, I4, VI, I6, viI, I 8 ; mark, plate LIX ; pieces sold since I 882 , I 30 , I 38 , I 40, I4 I, I 42, I43, I 44, I 47, I 5 I Palissy, Mathurin, reference, I 4 Nicolas, reference, I4

Paré, Minister of the Convention, I 794, suggests the limitation of Sèvres factory, I I I
Parent, M., succeeds Boileau at Sèvres, 98

Paris, faience manufactures in eighteenth century, 82 ; excelled in stoves and chimneypieces, $i b$. ; porcelain made ( 769 ) by Paul Hannong, 123; supported by the Comte d'Artois, $i b$. ; its polychrome flowers, $i b$.; the Trois-Levrettes, I 24 ; the Deux Flambeaux, ib. ; Clignancourt, ib. ; porcelaine à la Reine, ib. ; the factory of the Duc d'Angoulême, ib. ; its remarkable work, $i b$. ; patronised by the Duc d'Orleans, I25; the Prince of Wales' factory, ib. ; references, I I, I 4, I 5, 67, 77, 90, 96, 99, I05, I26; marks, plate Lxvi; pieces sold since I 882 , I 30 , I 46

Paulin, designer of Sèvres, 109

Pélissier, manager at Lille, I 22

Pénicaud, reference, 4

Penthièvre, Duc de, patron of Sceaux factory, 81; reference, $\mathrm{S}_{2}$

Périgord, reference, 9

Perrin, Veuve, her faience at Marseilles, 58, 65, 66, note, 69 ; piece with her mark, I 46 ; plate $\mathrm{E}, 60$; mark, plate Lix

Petit Carrousel, Rue du, factory mark, plate Lxvi

Peyre Cup, its adoption by the porcelain industry, i Io

Picard, Moustiers paintings influenced by, 48

Picardy, reference, 79

Piccolpasso, his works on ceramics, reference, 2

Pierre, French artist, his subjects utilised by Paul Hannong, $7 \mathrm{I}$

Pierrot, of the Orleans factory, I 27

Pigalle, Jean Baptiste, designer of Sèvres, I I 4 


\section{FRENCH POTTERY \& PORCELAIN}

Pithou, junior, Sèvres painterdecorator, $\mathrm{IO}_{3}$

Ploquin collection (first sale), 142, 148

Poirel. Nicolas de, revives the production of ceramics at Rouen, 29 ; cedes his rights to Poterat, 30 ; reference, 34

Poitiers, Diane de, references, 6, 7

Pompadour, Mdme. de, influences the revival of ceramics, 88 ; anecdote of, I 26

Porcelain ; see Arras, 128 ; Bordeaux, I28; Chantilly, I22; Lille, I22; Limoges, I27 ; Mennecy, I23; Orleans, I27 ; Paris, I23 ; Rouen, I 20 ; Saint Cloud, I2I ; Sceaux, I26 ; Sèvres, 87 ; Strasburg, I 27 ; Valenciennes, I 28 ; Vincennes, 125

Porcelaine à la Reine, produced by Le Bœuf at Paris, I24, mark, plate Lxvi

Poterat, Edmé, obtains Poirel's rights at Rouen, 30 ; director of the faience manufactures, 32 ; mark, plate LxIV

Poterat, Louis, son of the above, estabiished at Rouen, 32 ; obtains, I673, the royal licence ib. : rarity of his pieces, I2O; references, 24, I 2 I ; pieces sold since 1882 , I 32 , I 36 , I 37 ; valuable specimens from his workshop, I 36

Pot-pourri vases of Sèvres, the, I 12

Potter, an Englishman, establishes the Prince of Wales' factory, at Paris, I 789 , I 25

Pottier, André, his researches concerning Abaquesne, 2 ; on Henri-Deux ware, 4 ; discovers Palissy's methods, I7 ; his classification of Rouen manufactures, 42 ; reference, 29

Préaux collection, references, $\mathrm{I} \& \mathrm{I}, \mathrm{I} 42$
Prévost, pieces decorated by, I33, I 34

Provençal parliament, references, 45,50

Provence, references, 45, 49, 54, 57,64

- Comte de, afterwards Louis XVIII., visits the factories of Savy and Robert, 6o, 6 I ; supports the factory of Clignancourt, I 24

Prussia, Prince Henry of, presented with Sèvres porcelain, IO4

Pryne, Charles de, of Chazelles, reference, 28

QUIMPER factory, managed, I743, by Causay, 85 ; introduces the cornucopia ornament, ib. ; its paste, $i b$.

Rabelais, alludes to poteries azurées, I9

Raphael, reference, I I 5

Rattier collection, reference, $\mathbf{I 4 2}^{2}$

Rauenstein, its mark, note, 64

Raymond, Pierre, reference, 4

- Dr., collection, I 40

Regency style ; see Decoration

Regnault, Victor, succeeds Ebelmen at Sèvres, IO2

Régnier, M., appointed director at Sèvres, 98

Renaud, his biscuit porcelain at Valenciennes, I29

René, King, his abode at Marseilles, 53

Rennes factory, its manufactures inferior, 85; Forasassi and Bourgouin factories, $i b$. ; reference, 19; "Figaro bleeding a Patient," dish, I 37

Republic, first, marks, plate LXVIII

—— second, marks, II7, plate LXIX

third, marks, I 17 , plate IXX 


\section{INDEX}

Reux, reference, 18

Revolution, the, its effects on Nevers productions, 28 ; effects on Moustiers industry, 52; abolishes privileges of Sèvres factory, 94; effects on Sèvres productions, 99 ; many Sèvres pieces destroyed during, IO5; its effects at Limoges, 128

Ringler, associated with Paul Hannong at Haguenau, 70

Ris-Paquot, M., his researches in the history of ceramics, 29

Robbia, Girolamo della, decorates the Château Madrid, 2; Henri-Deux ware attributed to, to, 4 ; references, I I , 47

Robert, Joseph Gaspard, establishment at Marseilles, 58 ; his reputation, $\sigma_{I}$; visited by the Comte de Provence, 62; his services, 64 ; mark liable to be mistaken, note, 64 ; description of his work. 65 ; references, 66, 69 ; plates xxx, 56 ; xxxi, 58, 64 ; xxxirl, 64 ; mark, 63 , plate LXVII

- Louis, director at Sèvres, I 870,102

Rodin, Auguste, modern Sèvres statuettes signed by, I 6

Rohan, Cardinal de, instrumental in closing P. Hannong's factory, 7 I

Romano, Giulio, Roman painter, reference, 23

Romans, the, reference, 68

Roquette, Rue de la, the factories at, 124

Rouen faience, cessation of manufacture for two centuries, 3 ; revival under Poirel, 29, 30 ; cedes his rights to $\mathrm{E}$. Poterat, ib. ; influenced, at first, by Italy and Nevers, $i b$. ; creates a style of its own, 3I ; its rapid development, $i b$. ; L. Poterat obtains the royal licence, 32-34, 120; effects of
Rouen faience-Cont.

the privilege, 34 ; number of factories increased, 35 ; many directed by women, $i b$. ; first appearance of true stylc, 36 ; decorative more than realistic, ib.; polychrome decoration, 36,37 ; its greatest period, 37 , 38 ; its tile pavements, 38 ; cause of the large size of dishes, 39 ; the globes of $\mathrm{P}$. Chapelle, ib.; Chinese style utilised by Guillibaud, 40 ; figure subjects, $i b$. ; some rare examples, $i b$.; en rocaille and cornucopia ornamentation, 4I; classification of styles, 42 ; commands high prices, 42 ; references, II, 2 I , 22, 24, 26, $27,43,44,47,55,67,68,69,78$, $79,80,83,85$; plates xI, 29 ; XII, 30 ; XIII, 32 ; XIV, 33 ; $\mathrm{xV}, 34$; xVII, 36 ; xvIII, 37 ; XIX, 38 ; Xx, 39 ; xxI, 40 ; xxII, 4I ; XXIII, 42 ; marks, plates LxiIr, LxIv, Lxv, Lxvir ; pieces sold since ISS2, I $30-$ I 32, I34-I37, I39-I4I, I43, I 45, $147-149$, I 5 I, I 52

Rouen Museum, exhibits vase dated 1647,30 ; its large rare pieces, 38 ; Chapelles globes, 39 ; violin, 4I; Moustiers bust of the Virgin, 48 ; plates $\mathrm{xI}, 29$; XII, 30 ; XIII, 32 ; xIV, 33; xV, 34; xVI, 35; xVIr, 36 ; xVIII, 37 ; $x x I, 40$; xxir, 4I

Roux, Charles, collection, plates xxvirr, 53 ; $\mathrm{xxIx}, 54$; $\mathrm{xxx}$, 56 ; XXXII, 62 ; references, 58 , 66

Hyacinthe, épergne signed by, 50

Rouy factory, reference, 80

Royal factory, Bellevue, reference, 77

French manufactory, reference, 75 


\section{FRENCH POTTERY \& PORCELAIN}

Royal Manufactory of the Porcelains of France, title of Sèvres factory authorised by Louis XV., 90

_- Manufactory of Stanislas, 75

Saint Amand factory, founded by P. J. Fauquez, 84 ; its styles, ib.; painters, 85 ; marks, plates LXV, LXVII; piece sold, I 887 , I 39

St. Clément, factory of Lunéville, 76 ; references, 72,74

Saint Cloud faience factory, Chicoineau's first productions, 82; made services for the royal household, $i b$. ; managed by Tron ; porcelain ; Chicoineau's widow obtains royal permission, I2I ; manufactory destroyed by fire, $i b$. ; description of ware, $i b$. ; references, 84,87 , IOI, I 20 , I22 ; plates G, I 20 ; LIV, I2I ; mark, I2I, plates LXV, LXVI; piece sold, I 884 , I 32

- palace of, Régniers vases at, 99

St. Etienne, Dame de, factory at Rouen, 35

St. Jean du Dèsert, the first Marseilles factory, 55,56 ; plate $\mathrm{xxvi}, 48$

Saint Omer factory, pieces in the style of Bordeaux, 84

St. Petersburg, Museum of the Hermitage at, reference, II 5

St. Pierre, Chapel de, Auriol, tiles preserved at, 53

St. Porchaire, Faience of ; pieces sold since I882, I43, I44, I45, I 47 ; see also Oiron and HenriDeux

Saint-Sever a suburb of Rouen. 32,33

- Church of, faience inscription at, 39

Saint Simon, Louis de Rouvroi, quoted, 3 I
Saint-Yrieux, reference, 97

Saintes, references, IO, I4

Salmon, M., director at Sèvres, until I 800, IO2

Salomé, Spanish painter, associated with Moustiers, 50

Salting, George, Esq., pieces from his collection, plates II, 9 ; III, IO ; IV, I 2 ; , I4 ; VII, I 8

Samadet factory, references, 83 , 86

Sartines, Lieut.-General of Police, reference, 92

Sauvage, Charles ; see Lemire

Savignies, vases de, reference, 20

Savona, reference, 59

Savoy, Honoré of, arms in church, Marseilles, 53

Savy, Honoré, established at Marseilles, 58 ; re-establishes Clerissy's factory, 59 ; visited by the Comte de Provence, 60, 6I; his green enamel, 6I; reference, 66 ; mark, plate LIX

Saxony, references, 22, 26, 28, 6I, $69,73,76,87,91,94,95$, II 2 , I I 4, I 22 , I 24, I 28

Saxony, the Duke of, presented with Sèvres porcelain, IO4

Sceaux faience factory, its first manager, Chapelle, $8 \mathrm{I}$; succeeded by Glot, $i b$. ; some of its work comparable with porcelain, $i b$. ; articles produced, $i b$. ; supported by the Duc de Penthièvre, $i b$. ; produced faience and porcelain decorated with flowers, I26 ; plate XLIV, 82 ; marks, plates LXV, LXVII; pieces sold since I 882, I 37, I $39,143,146,152$

Schilt, reference, I I 5

Secretan collection, I4I

Seillière, Baron, collection, I4I

Sejourné, François, Rouen, piece bearing the name of, I 34

Sevigné, Madame de, references, 44,45

\section{2}




\section{INDEX}

Sèvres, its productions compared with those of Rouen, 36 ; old Roman dishes at, 55 ; the Dresden of France, 87 ; French porcelain inferior at the beginning of eighteenth century, $i b$.; ceramic work not mentioned in edict of 1667,88 ; Madame de Pompadour's influence, $i b$. ; the secret process claimed by the brothers Dubois, $i b$; their connection with M. Fulvi, 89; Gravant becomes chief worker. $i b$. ; formation of company, 89 ; M. Orry organises the establishment, ib.; Louis XV.'s donations, 90 ; death of Orry and reorganisation under Brichard, $i b$. ; establishment of new factory, $i b$. ; the King subscribes a fourth of the capital, ib.; Falconet and Genest added to the staff, $i b$. ; company unsuccessful 91 ; appeals to the King, $i b . ;$ the King revokes licence and returns shareholders' money, $i b$. ; the King grants it a monopoly, 92 ; private makers complain of monopoly, ib. ; the Revolution abolishes all privileges, 94; soft paste used in 1759 . ib.; Busch and Stadelmeyer profess knowledge of the secret of Saxon porcelain, 95; experiment unsuccessful, $i b$. ; Wackenfeld and Charles Hannong start factory at Strasburg, 95 ; threatened by the Sèvres factory, 96 ; Paul Hannong negotiates with Sèvres, $i b$. ; fails to satisfy the authorities, is prosecuted and furnaces destroyed, $i b . ;$ founds factory at Frankenthal, $i b$. ; Joseph Hannong's attempts to negotiate unsuccessful, 97 ; Pierre Hannong secures cash payment and annual pension,
Sèvres-Cont. ib.; discovery of kaolin by Madame Darnet, 98 ; death of Boileau, ib. ; Parent committed to prison, $i b$. ; Régnier appointed, $i b . ;$ effects of the Revolution, 99; Louis XVI. reduces expenditure, IOO ; revolutionaries demand its suppression, IOI ; Brongniart succeeds Batelier as director, IO2 ; Ebelmen succeeds Regnault, $i b$. ; Louis Robert appointed administratior, $i b$. ; succeeded by Lauth, Deck, Baumgart, Coutan, and Vogt, IO3; its income at various dates, $i b$.; some of its artists, ib. ; productions dedicated to diplomatic presentations, $i b$. ; some of the presentations, IO4 ; many objects given to museums, ib. ; shop in Paris, I05; chief works, $i b$. ; the most precious in Wallace and Vindsor collections, $i b$. ; George IV.'s passion for the ware, $i b$. ; its variety and richness of colouring, I06; M. Garnier on its paste, I06-108; productions classified, Io8; pieces designed by Duplessis and others. IO9; alterations and modification of decoration, I IO; adoption of the Peyre cup by porcelain industry, $i b . ;$ its vases and important pieces, III-II3 ; biscuit-porcelain statuettes, II3, II4; its imitation of paintings, II 4 ; reproductions of old masters, II 5 ; references, 22, 61, 67, 70, 120, 122, I23, I24. 125, I28; plates XVI, 35 ; XLVI, 90 ; XLVII, 94 ; XLVIII, 98 ; XLIX, IO2 ; L, IO4; LI, I08; LII, II 2 ; LIII, II6 ; marks, II6-I I9 ; plates LXviII, LXIX, LXX; pieces sold since 


\section{FRENCH POTTERY \& PORCELAIN}

Sèvres-Cont.

I 882 , I $30-134, I_{3} S$, I 4 I, I 42 , I44, I 5 O, I 5 I

Sèvres Museum, della Robbia's decoration at, note, 2 ; Palissy examples, I5; poteries azurées of Beauvais, 20 ; Nevers pouchshaped bottle, 26 ; David and Bathsheba dish, ib; Moustiers dishes, 46 ; old Marseilles pottery, 53 ; dish by Robert, 64 ; sauce-boat by Paul Hannong, $7 \mathrm{I}$; portable altar, Lille, 79 ; references, 29, I25; plates I, 4 ; vIII, 22 ; Xxxvi, 68 ; xL, 73 ; xLIV. 82 ; xLV, 87; XLVI, 90; xLVII, 94 ; XLVIII, 98 ; XLIX, IO2 ; L, IO4; LII, II 2 ; LIV, I $2 \mathrm{I}$; LV, I 22 ; LVII, I 26 ; LVIII, I 28

Siena, reference, 23

Sinceny, faience, Fayard founds first manufactory, 79 ; makers from Rouen and Nevers settle there, $i b$. ; decoration, $i b$. ; arabesques and polychrome designs, 80 ; Louis XVI. figurines very rare, $i b$. ; its Louis XVI. plates and marks, ib. ; Le Cerf and Bornes work there, $\mathrm{SI}_{\mathrm{I}}$; references, 72,85 ; plate $\mathrm{F}, 80$; marks, 8o; plate LxV; pieces sold since I 882, I 35, I 43,146

Solira, Spanish painter, associated with Moustiers, 50

Soltykoff sale, reference, I 42

Sommerard, M., on the origin of Henri-Deux ware, 4

Souboux, manages Rue de la Roquette factory, I 24

South Kensington Museum, Palissy examples at, I 5 ; Moustiers and Rouen dishes acquired by, 139; plates $\mathrm{A}$, frontispiece; C, 28 ; E, 60; $\mathrm{F}$, So ; $\mathrm{G}$, I20 ; vI, I6; $\mathrm{x}$, 26 ; xxxv, 66; xxxvil, 69; XXXIX, 72 ; XIr, $74 ;$ XLII, 76 ; Lr, IO8; LIII, I I6
Spain, references, $43,49,83$

- Queen of ( $176 \mathrm{I}$ ), presented with Sèvres service, IO4

Spanish painters at Moustiers, 50 Spitzer collection, I44, I 47

Stadelmeyer, professes knowledge of the secret of Saxon porcelain, 95

Stahremberg, Comte de, presented with Sèvres service, IO4 Stanislas, King, reference, 77

"Stanislas, Royal Manufactory of," founded by Chambrette at Lunéville, 75

Stein, Ch., collection, $\mathrm{I}_{47}$

Strasburg faience, its occasional imitation of styles, 22 ; style of ornamentation compared with that of Rouen, 36 ; Alsace, its ceramic art and potteries, 68 ; its position at the beginning of the eighteenth century, ib. ; Wackenfeld's attempt to establish a porcelain factory, 69 ; Charles Hannong founds a faience factory, $i b$.; joins Wackenfeld to make porcelain, ib. ; sets up factory at Haguenau, $i b$. ; relinquishes both to his sons, 7o; they separate, ib. ; Paul Hannong buys Haguenau, $i b$. ; makes porcelain assisted by Ringler and Löwenfinck, $i b$.; his difficulties at Sèvres, founds Frankenthal, $i b$. ; his sons continue but factory is sold, $7 \mathrm{I}$; products divisible into three periods, $7 \mathrm{I}$; their characteristics, 7I, I27; Chinese style utilised. 72 ; references, 73,76 , $78,80,84,86,95,96$, I 23 ; plates xxxv, 66 ; xxxvi, 68 ; xxxviI, 69 ; XxxVIII, 70 ; LVIII, I 28 ; marks, plate Lxv; piece sold in I 890,142

Subjects and names of celebrated pieces :

Adam and Eve (Rouen), I36 


\section{INDEX}

Subjects and names of celcbrated pieces (continued):

Adonis, Death of (Lemire), 75

Adonis surprising the Sleeping Venus, 40, 75

Adoration of the Magi (Nevers), I 3 I

Apollo, Mloustiers, I35 I49,

Apollo and Venus (Lemire), 75

Arms : Honoré of Savov, 53; Jacques Arrelin, I 37 ; Lorge, Mdme. de, 135; Montmorency, I 32 ; Louis, Poterat, I 37 ; Orleans family, 146 ; Richelieu-Guise, 135 ; Sinceny, Seigneur de, I 35

Atala (Girodet), I I 5

Bacchante (Lemire), 75

Bacchus upon a barrel (Rouen), 38

Bacchus and Bacchante (Lemire), 75

Bagpipe Player (after Palissy), 19

Battles, 48

Bear Hunt (Moustiers), I46, I 49

Beggars (Cy fflé), 75

Bélisaire Begging (Cyfflé), 139

Bull Baiting, I 49

Bustard Hunting, 47, 149

Cephalus and Aurora (Mousstiers), I 49

Ceres (Moustiers), 149

Chimney Sweeps (Cyfflé), I 39

Child pursued by a Hound (after Palissy), ig

Christ (Lemire), 75

Christians and Saracens, 46

Cobbler (Cyfflé), 75

Coupe de Fragonard, I 13

Crouching Chinamen (Chantilly), I 22, I 38

Crucifixion, 38

Cupid, 4I, 50, 75, I I I , I 37, I 39, $141,150,151,152$

Danae and the Golden Rain, 40

David and Bathsheba, 26

Départ pour Cythère (Schilt), I 5
Subjects and names of celebrated pieces (continued) :

Diana, Palissy, I44, I.47

Diana at her Toilet (Moustiers), 49, 149

Dutch Drinkers, 27

Earth and Water (Palissy), I 38

Figaro bleeding a Patient, I 37

Garde à Vous (Statuettes), I 3 I

Genius with Vase (Lemire), 75

Globes (Pierre Chapelle), 39, 40

Good Samaritan, the, 47

Henri II. and Diane de Poitiers cyphers and crescents, 6,7 ,

I 41 and Catherine de Medici,
monograms, I 41,144,

Housewife in a Spice Box, 136

Hoche, bust, I 30

Hunting Scenes, 47, 48, 75

Jesus and the Woman of Samaria, 40

Judgment of Paris, the, 75, 143

Judith and Holofernes, 40

Jupiter, I 49

Jupiter and Juno (Lemire), 75

La Belle Jardinière (Palissy), 140

La Fecondité, or La Charité (Palissy), I 42, I43, 144

L'Eau (Palissy), I 44

Leda and her Swans, 50

Madonna, the (Raphael), I I 5

Marat, busts (Sèvres), I 30

Marcus Curtius, 2

Market-Porter, a (Chantilly), I 35

Meditation of a Spinner (Lemire), 75

Mithridates (Marseilles), I49

Mucius Scævola, 2

Muses and Apollo (Lemire), 75 Musical Inscriptions (Rouen), $35,36,4$ I, I 51

Napoleon, bust, I 30

Neptune standing upon the Waves, I 44 


\section{FRENCH POTTERY \& PORCELAIN}

Subjects and names of celebrated pieces (continued) :

Nurse, the (after Palissy), I9

Painting and Sculpture (Lemire), 75

Pastry-Cooks (Cyfflé), 75

Perseus and Andromeda, 24, 142 I 48 ,

Peyre Cup, i io

Pomona and Spring (Palissy), I 44

Prometheus and Pygmalion (Sèvres), I 50

Psyche (Gerard), I I 5

Rape of Europa, 24, 146

Rape of Helen (Lemire), 75

Roman Chariot (Nevers), I 48

Rousseau; i 36

St. John (Rouen), 40

St. Joseph (Moustiers), 47, 48, 149

St. Michael and the Dragon, I 36 Savoyard Scenes (after Pierre), 7 I

Savoyards (Cyfflé), 75

Seasons, the (Rouen), I 49

Seated figures (Lemire), 75

Shepherd and Shepherdess (Lemire), 75

Large (Lemire), 75

Spring (Cyfflé), 75

Stag-hunt, 47, 149

Stocking-Darner (Cyfflé), 75

Surtout-de-table Olympique (Sèvres,) I I 3

- Egyptien, I I 3

Tambourine Player (after $\mathrm{Pa}$ lissy), I9

Temperance (Palissy), I 38

Tiger Hunt (Moustiers), I 40

Tinkers and Hawkers (Cyffé), 75

Triumph of Amphitrite (Rouen), I 45

Triumph of Cybele (Rouen), 40 Triumph of Juno (Rouen), I 40

Vase à Anses (Sèvres), I I 2

—_ à l'Amour (Falconet) (Sèvres), I I 2
Subjects and names of celebrated pieces (continued) :

Vase aux Tritons (Sèvres), I I 2

- Bachelier des Saisons (Sèvres), I 12

Comète (Sèvres), I 12

- Cordelier (Sèvres), I I 3

Etrusque (Sèvres), I I 3

Fuseau (Sèvres), I I 3

Medicis (Sèvres), I I 2

Militaire (Sèvres), 112

(Euf (Sèvres), I 3

Ovale (Sèvres), 112

- Paris (Sèvres), I I 2

— Percier (Sèvres), I 3

-_ Ruche d'Abeilles, I I 2

Tulipe à Oreilles, I I 2

Vaisseau à Màt, I I I

Vases à côtes torses, I I 2

Venus and Adonis (Lemire), 75

Venus and Bacchus, 75

Venus and Neptune (Nevers), 146

Venus Kneeling, 75

Virgin (St. Porchaire), 147

—_ Bust (Moustiers), 48, I 49

- Statue of the(Marseilles), 58

Virgin and Child (Rouen), I 5 I

Voltaire, I36

Vulcan surrounded by Divinities (Rouen), I40

Wafer-Sellers, 75

Young Man surprising a Woman Bathing (Sinceny), I46 Sulmont, L., of Rouen factory, I 740,35

Sweden, King of (I784), presented with Sèvres service, \&c., 104

TANDART, pieces decorated by, (Sèvres), I 33

Tempesta, Antonio, references, $46,57,66$

Thomire, reference, I I 3

Thoré, M., on Henri-Deux ware, 4 Thouret, Sèvres service decorated by, 109 


\section{INDEX}

Tiles, Abaquesnes at Rouen, 2 ; at Rouen, 38 ; at Villeray, 38 ; at Auriol, 53

Toro, B of Toulon, reference, 48 Toul, reference, 77

Touquay, faience factory at Rouen, 35

Tours, reference, 14

Trois-Levrettes, Manufacture des, Paris, 124

Tron, manages St. Cloud factory, 82 , I 21 , I 32 ; marks, plate LXVI

Tuileries, references, I4, I 8

Urbino faience, piece sold, I 895, . 145

Valenciennes factory, founded by Fauquez, I28; its sources of inspiration, $i b . ;$ Fernig's paintings, I29 ; Fickaert and Renaud's biscuit porcelain, ib. ; references, 79,85

Vannier, associated with Fauquez at Valenciennes, I 28

Var, references, 54, 55

Varages, factory, 78,86

Vélox, Spanish painter, Mousstiers, 50

Verneuil, reference, $s$

Verneuille, Bordeaux porcelain factory, I 28

Vernet, Joseph, reference, 65

Verona, reference, 23

Versailles, references, 34, 90

Vienna factory, reference, I 20

Vienne, factory at, 70

Vieillard, Sèvres painter-decoraator, IO3; pieces decorated by, I 33 , I 34

Villaris, a Bordeaux apothecary, 98
Villeray, tiles of, refercnce, 38

Villeroy, the Duke de, founds Mennecy factory, 123

Vincennes, the royal factory before Sèvres, I25; its flowers, $i b$. ; soft porcelain, $i b$. ; a necdote of IIadame de Poinpadour, I26; references, 88, 89, 90, 92, II8; plate XLV, 87; mark, plate LXVII ; pieces sold since I 882, I 34, I 37

Violin in Rouen Museum, plates $\mathrm{xIx}, 38 ; \mathrm{xx}, 39,4^{\mathrm{I}}$

Viry, G., signature, Moustiers dish, 46; Good Samaritan dish, 47; Bear Hunt dish, I 46 ; references, 48,66

- J. B., son of the above, established at Marseilles, 58 ; references, 48,66

Vogt, M., Sèvres director, IO3

WACKenfeld, Jacques Henry, escapes from Meissen and joins Hannong, 69; references, 7 I, 95

Waddington sale, reference, 148

Wales, Prince of, afterwards George IV., his taste for Sèvres porcelain, 105 ; factory established by Potter, I25; mark, plate LXVI

Wallace collection, most precious Sèvres pieces to be found in, 105 , I I I

Watelin collection, I 35

Watteau, J. A., references, 76, I 39

Wiermont, Dr., reference, 8I

Windsor Castle, collection at, reference, I05

Yvon, D', collection, I43 


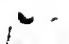

298 


$\|$ 
UNIVERSITY OF CALIFORNIA LIBRARY

Los Angeles

This book is DUE on the last date stamped below.

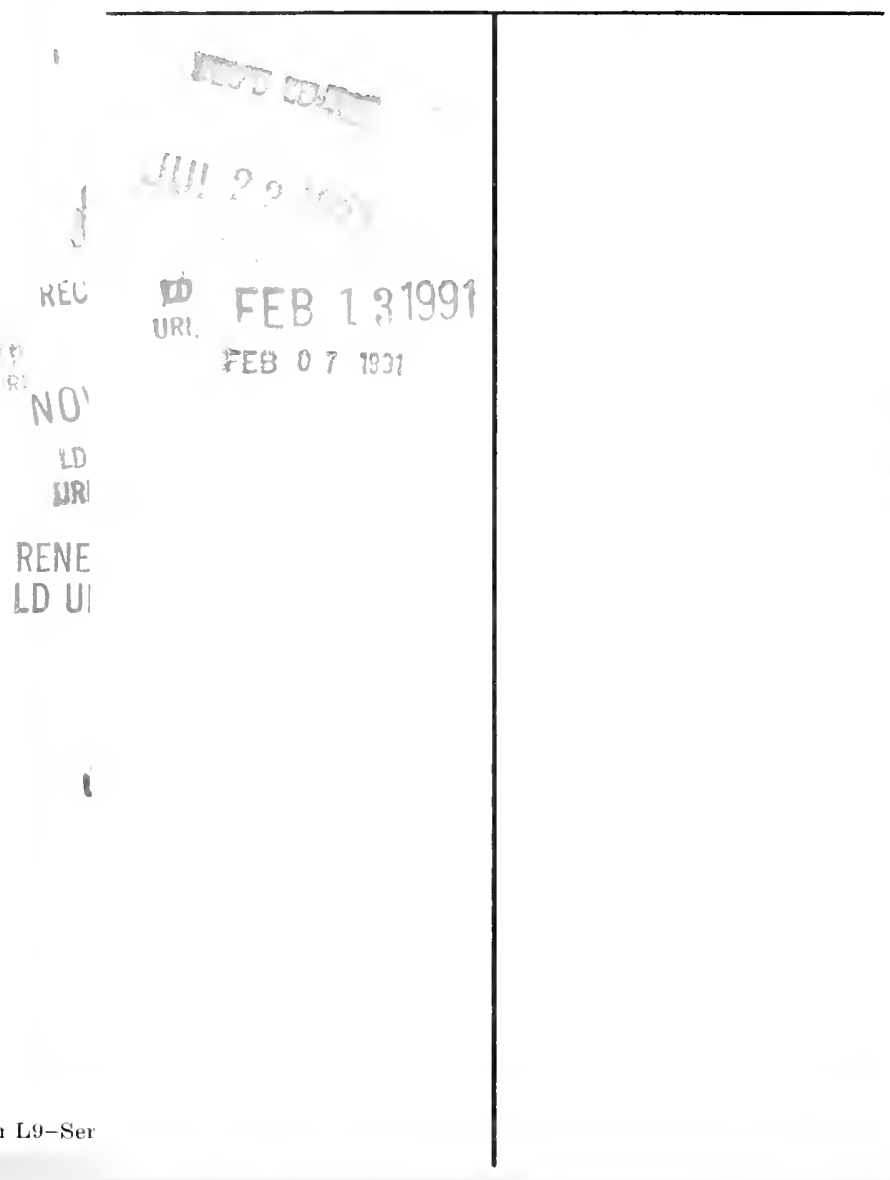




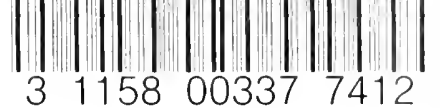

b.

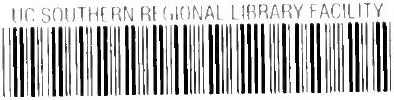

AA 0006073530

SD 
